\title{
Measurement of total hydrocarbon emissions with MEMS using a portable FID and a novel exhaust flow meter
}

Jared Gregory Knight

West Virginia University

Follow this and additional works at: https://researchrepository.wvu.edu/etd

\section{Recommended Citation}

Knight, Jared Gregory, "Measurement of total hydrocarbon emissions with MEMS using a portable FID and a novel exhaust flow meter" (2002). Graduate Theses, Dissertations, and Problem Reports. 1283.

https://researchrepository.wvu.edu/etd/1283

This Thesis is protected by copyright and/or related rights. It has been brought to you by the The Research Repository @ WVU with permission from the rights-holder(s). You are free to use this Thesis in any way that is permitted by the copyright and related rights legislation that applies to your use. For other uses you must obtain permission from the rights-holder(s) directly, unless additional rights are indicated by a Creative Commons license in the record and/ or on the work itself. This Thesis has been accepted for inclusion in WVU Graduate Theses, Dissertations, and Problem Reports collection by an authorized administrator of The Research Repository @ WVU. For more information, please contact researchrepository@mail.wvu.edu. 
Measurement of Total Hydrocarbon Emissions with MEMS using a Portable FID and a Novel Exhaust Flow Meter

\author{
Jared Gregory Knight
}

Thesis submitted to

the College of Engineering and Mineral Resources

at West Virginia University

in partial fulfillment of the requirements

for the degree of

\author{
Master of Science \\ in \\ Mechanical Engineering \\ Mridul Gautam, Ph.D., Chair
Gregory J. Thompson, Ph.D.
W. Scott Wayne, Ph.D.
Department of Mechanical and Aerospace Engineering
}

Morgantown, West Virginia

2002

Keywords: HFID, V-Cone Flow Meter, Diesel Emissions, On-Road Emissions Testing 


\title{
Measurement of Total Hydrocarbon Emissions with MEMS using a Portable FID and a Novel Exhaust Flow Meter
}

\author{
Jared Gregory Knight
}

\begin{abstract}
1 ABSTRACT
The objective of this study was to evaluate tools for in-field, on-board engine emissions measurements, namely, a Signal Model 3030PM hydrocarbon analyzer and McCrometer's V-Cone flow meter. The Signal Model 3030PM analyzer uses a heated flame ionizing detection scheme to measure hydrocarbons. The V-Cone is an obstructive, differential pressure flow meter that reshapes the flow profile, therefore conditioning the flow.

The Signal Model 3030PM analyzer was found to perform as well or better than the HC analyzers currently used in the FTP test cell. Besides the portability feature, the Signal Model 3030PM demonstrated better response, being able to capture the high and low concentrations better. Concerns for the Signal are its ability to measure raw diesel engine exhaust, hydrocarbon hang-up, and the non-essential features that are currently part of the instrument.

When compared with an Annubar ${ }^{\circledR}$ flow meter, the V-Cone measured consistently higher than the Annubar ${ }^{\circledR}$ for the flow rates and this translated into higher mass rates. After recalculating the V-Cone values using the correction factor, the V-Cone had integrated errors of less than 5\% for transient tests and $10 \%$ for steady state tests when compared to the Annubar. The V-Cone needs more testing to ensure the accuracy of the V-Cone with the Laboratory; those studies should include the Annubar ${ }^{\circledR}$. Other concerns of the V-Cone include: the weight of the instrument does not lend itself to mobile emissions measurements; also mode- 8 of the steady state tests gave erroneous flow rates. If these concerns could be addressed, the V-Cone could be a viable option as an exhaust flow meter for in-field, on-board emissions measurements.
\end{abstract}




\section{ACKNOWLEDGEMENTS}

I am honored and humbled that for the last two years I have been able to work with some of the best minds in engine emissions research. I have learned more from watching and listening to these engineers than I ever could have if I had studied some book. Thank you to all the people that I worked with and who shared their knowledge with me.

First and foremost, I give praise to my Lord and Savior Jesus Christ. Without you, I have no hope. Thank you, Lord, for the blessings that you have given to me, from my colleagues to my friends, my abilities, my family, my wife, everything I have Lord. Continue, Lord, to let me grow in You.

Dr. Gautam, thank you for giving me the chance to grow as an engineer and to learn about engine emissions. Under your guidance, I have become a much better engineer. Secondly, I want to thank the team of engineers that I have worked with, Dan Carder and Wesley Riddle. It has been a privilege to work with you guys and learn from you. You guys work way to hard, take a vacation. Dr. Thompson and the staff at the engine lab, Richard, Tom, Andy, you guys are masterful. I don't know how many times that you helped me, but thank you for it. Lastly, I would like to thank the students that I had the privilege of working with, Ryan and Aaron Barnett, Jeremy Rohrbaugh, Tim Hall, Steve and Nick, Vinay, Guru, Mohan, Sam, John and Axel (even though I didn't work that long with you guys), and to the hourly workers. I leave things in your hands. 
I must thank my beautiful wife, Sara, for being patient with me as I tried to reach this milestone. Your encouragement made me strive to do the best job I could possibly do. Thank you for listening to my frustration, and being proud of my accomplishments. You are best. I love you more and more everyday. Thank you for marrying me.

I also need to give thanks to my family. Mom and Dad, thank you for setting an example for me. To my sisters, Jennifer and Julie, thank you for putting up with me for all these years. You are the best sisters a brother could have. And thank you for willingly taking all the abuse that I gave out over the years. You are wonderful.

I know that the person I have become has been the results of many, many people's efforts. To all of you, I would like say thanks. 


\section{TABLE OF CONTENTS}

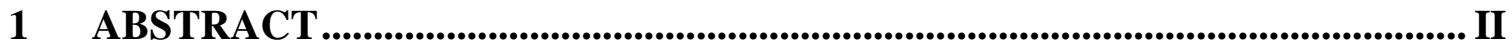

2 ACKNOWLEDGEMENTS ..........................................................................II

$3 \quad$ LIST OF FIGURES .................................................................................... VIII

4 LIST OF TABLES …......................................................................................

5 NOMENCLATURE........................................................................................ XIII

CHAPTER 1 INTRODUCTION ............................................................................. 1

CHAPTER 2 LITERATURE REVIEW ......................................................................... 7

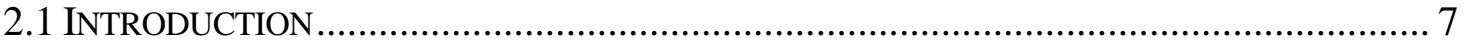

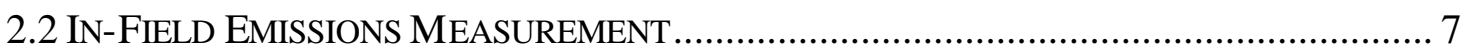

2.2.1 Southwest Research Institute ………………............................................ 7

2.2.2 Michigan Technological University............................................................. 8

2.2.3 University of Minnesota.......................................................................... 8

2.2.4 University of California, Riverside …………............................................ 9

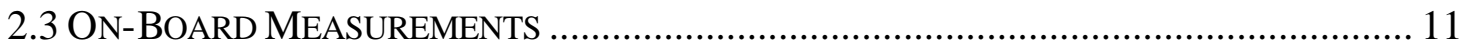

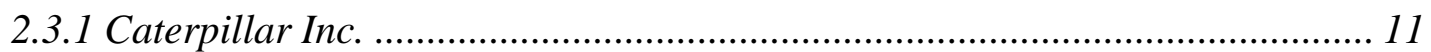

2.3.2 Southwest Research Institute .................................................................... 11

2.3.3 General Motors ……………………………….............................. 12

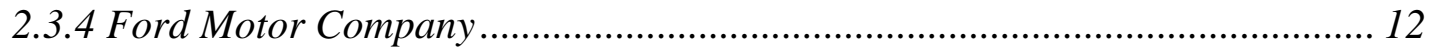

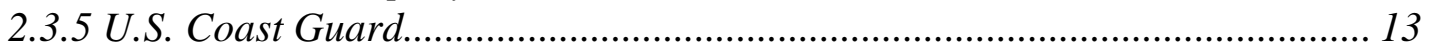

2.3.6 University of Pittsburgh......................................................................... 13

2.3.7 VITO, The Flemish Institute for Technological Research ............................... 14

2.3.8 Northeast States for Coordinated Air Use Management ................................. 14

2.3.9 Office of Mobile Sources: USEPA ………………….................................. 15

2.3.10 Ford Motor Company and WPI-Microprocessor Systems, Inc ................... 15

2.3.11 Horiba Inc. and NGK Insulators, Ltd.................................................... 15

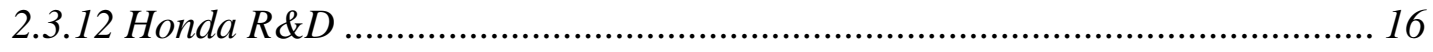

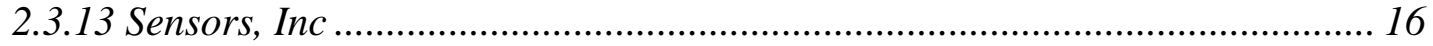

2.3.14 Clean Air Technologies International ..................................................... 16

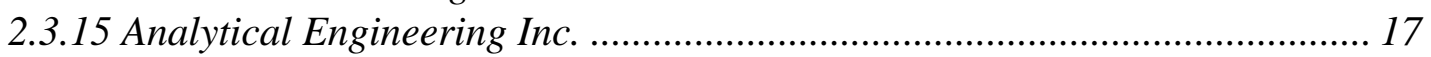

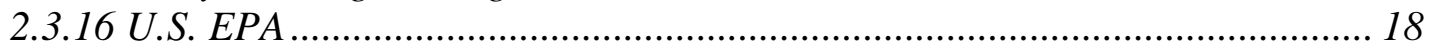

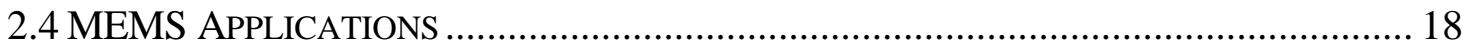

2.4.1 MEMS Brake Specific NOX Emissions Measurement .................................... 18

2.4.2 CARB Off-road Project....................................................................... 19

2.4.2.1 In-field $\mathrm{CO}_{2}$ Emission Data .............................................................. 19

2.4.2.2 Track-Type Tractor In- field Results ..................................................... 20

2.4.2.3 Stationary Testing ............................................................................. 21

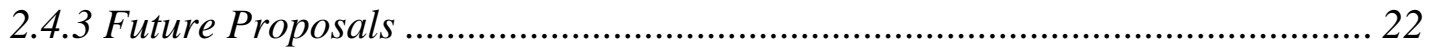




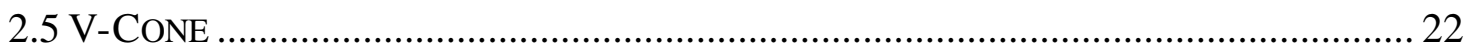

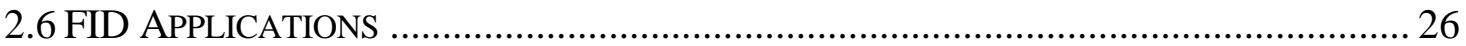

CHAPTER 3 EXPERIMENTAL SETUP ........................................................................ 27

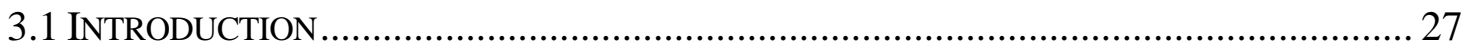

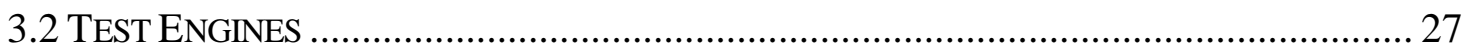

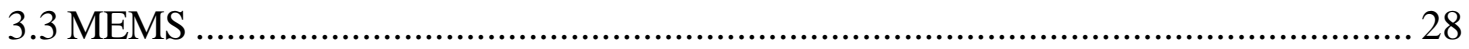

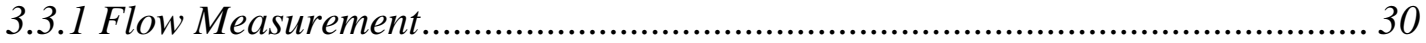

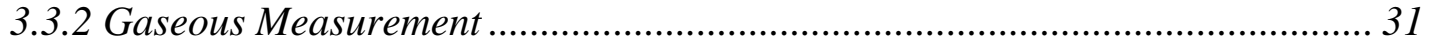

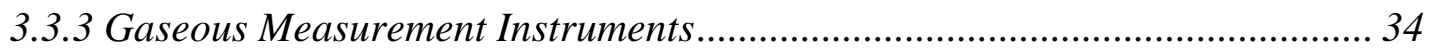

3.3.3.1 Horiba BE-140 Multigas (CO, $\left.\mathrm{CO}_{2}, \mathrm{HC}\right)$ Analyzer .................................... 34

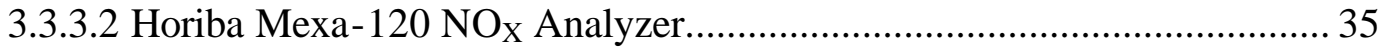

3.3.3.3 Sensors Inc. Electrochemical NO Cell................................................. 38

3.3.3.4 Thermoelectric Chiller: M\&C Products Analysis Technology Inc. Model

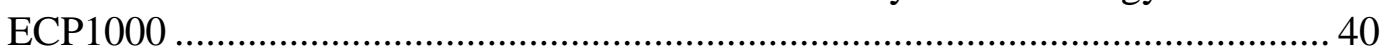

3.3.3.5 Engine Speed and Torque …………………...................................... 40

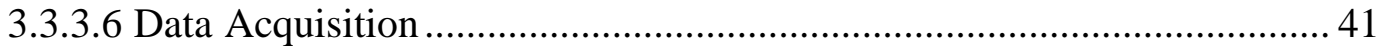

3.4 SIGNAL MODEL 3030PM HYDROCARBON ANALYZER ……….............................. 43

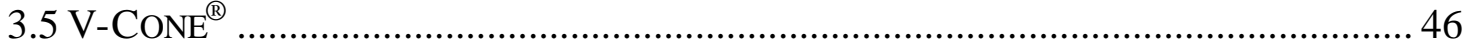

3.6 WEST VIRGINIA UNIVERSITY'S ENGINE AND EMISSIONS RESEARCH LABORATORY 51

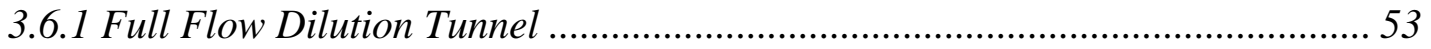

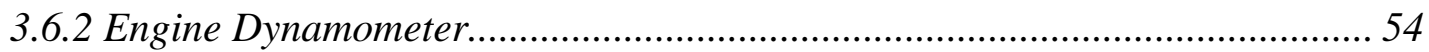

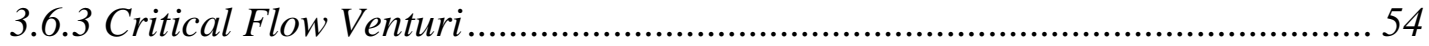

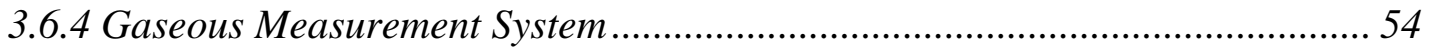

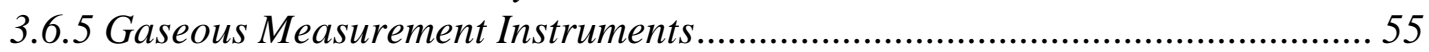

3.6.5.1 Hydrocarbon Analyzer ..................................................................... 55

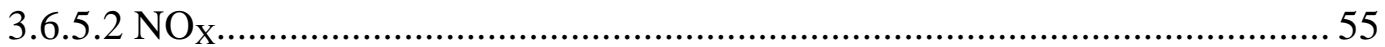

3.6.5.3 Horiba Model AIA-210-10-LLCO …………….................................... 56

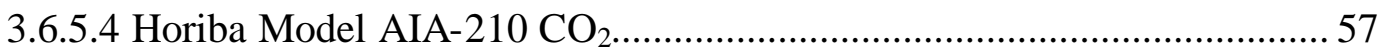

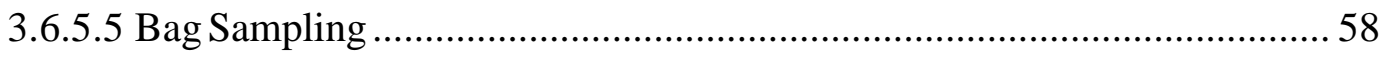

3.6.5.6 Fuel and Air Sampling ....................................................................... 58

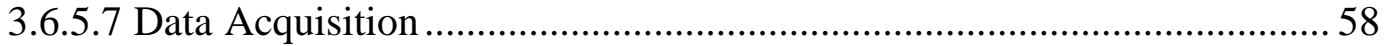

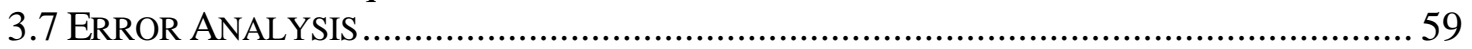

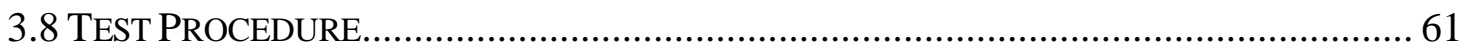

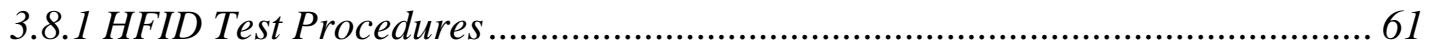

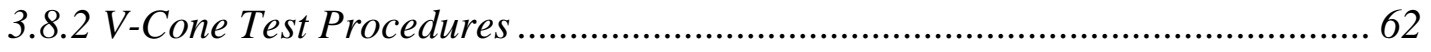

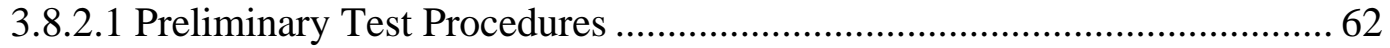

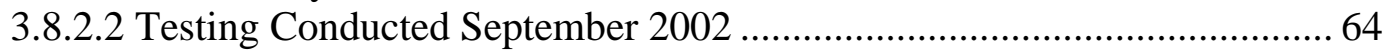

CHAPTER 4 RESULTS AND DISCUSSION ............................................................67

4.1 HYDROCARBON ANALYZER HFID VALIDATION TESTING.......................................... 67

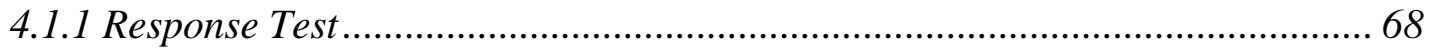

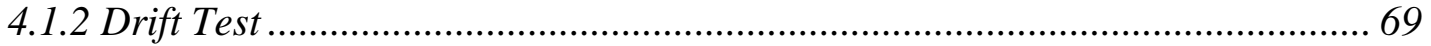

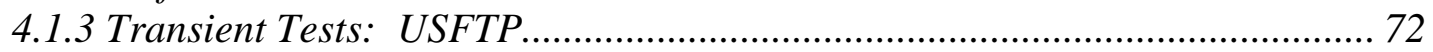

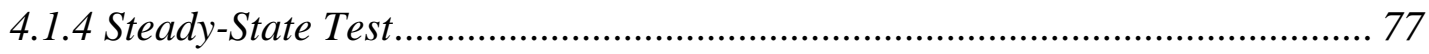




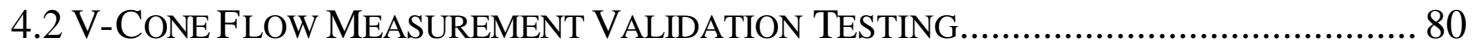

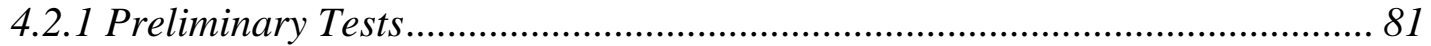

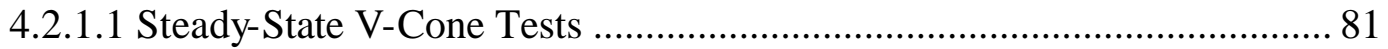

4.2.1.2 Transient Tests: Dozer Cycle ............................................................... 83

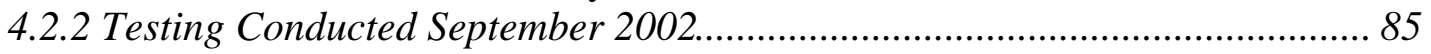

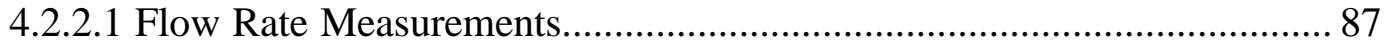

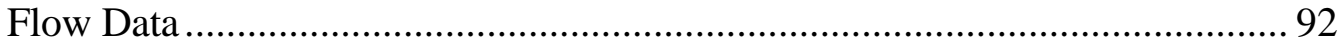

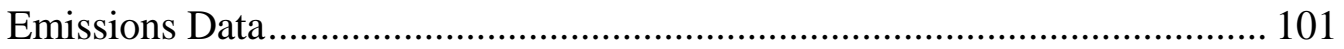

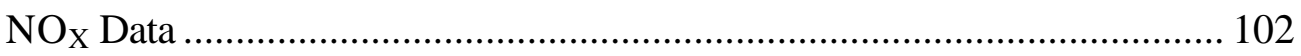

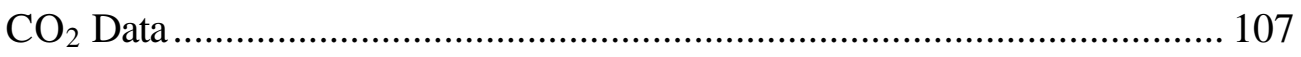

CHAPTER 5 CONCLUSION

5.1 SignAL MODEL 3030PM PORTABLE VOC HYDROCARBON ANALYZER ................ 116

5.2 MCCROMETER'S V-CONE FLOW METER........................................................... 118

CHAPTER 6 RECOMMENDATIONS ........................................................ 120

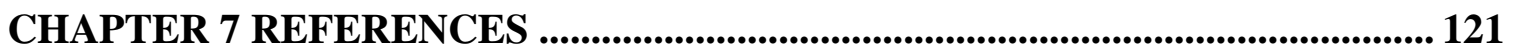

CHAPTER 8 APPENDIX ..................................................................................................... 124

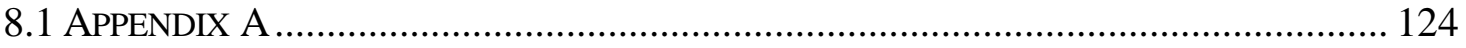

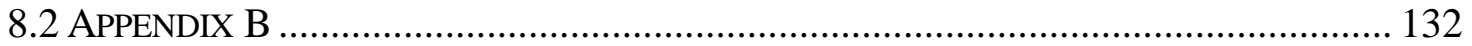

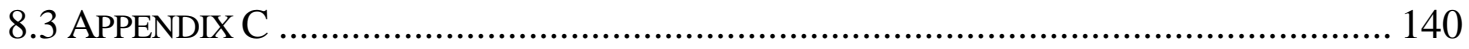

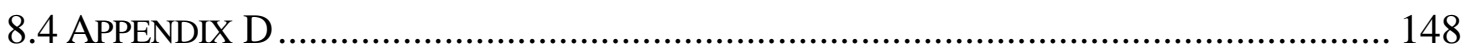




\section{LIST OF FIGURES}

Figure 1.1 Signal Model 3030PM portable hydrocarbon analyzer.................................... 5

Figure 1.2 A cutout of the V-Cone showing the conical mass in the center of the flow,

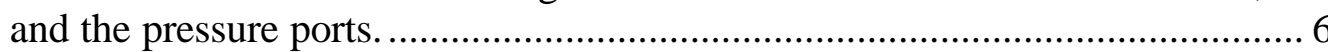

Figure 3.1 The WVU EERL test cell with an engine on the dynamometer, and the exhaust system. The Annubar ${ }^{\circledR}$ can be seen in the upper left hand corner.................... 28

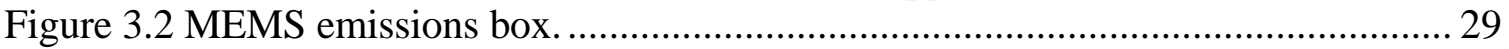

Figure 3.3 System integration of MEMS with the engine. .............................................. 30

Figure 3.4 Second generation MEMS exhaust sampling system........................................ 33

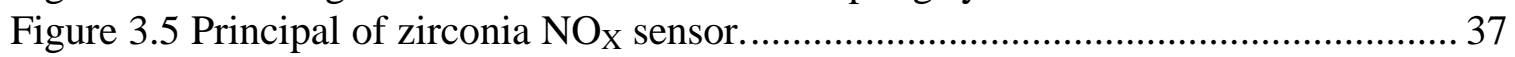

Figure 3.6 Electrochemical NO cell schematic............................................................ 39

Figure 3.7 Signal Model 3030PM portable hydrocarbon analyzer................................... 44

Figure 3.8 A cutout of the V-Cone showing the conical mass in the center of the flow,

and the pressure ports................................................................................. 47

Figure 3.9 Schematic of the test cell at WVU's EERL. The flow path is shown as well. 52

Figure 3.10 Reattime rpm and torque for the steady state test cycle..............................63

Figure 3.11 Reattime rpm and torque data for the dozer test cycle................................ 64

Figure 3.12 Realtime speed (rpm) and load (ft-lbs) for the transient test cycle, the

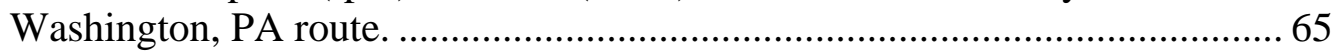

Figure 3.13 Realtime rpm and torque data for the 9-mode steady state test. .................. 66

Figure 4.1 The response test using a span gas of $20 \mathrm{ppm}$ propane................................. 68

Figure 4.2 A small scale time frame of the response test showing the response of the instruments.

Figure 4.3 Hydrocarbon comparison of the HFID for a zero air drift test, showing a scale

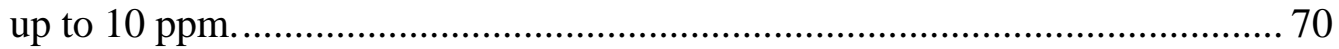

Figure 4.4 Hydrocarbon comparison of the HFID for a zero air drift test........................ 70

Figure 4.5 Hydrocarbn comparison of the HFID for a span drift test.............................. 71

Figure 4.6 Hydrocarbon comparison of the HFID for a span gas drift test, reduced scale.

Figure 4.7 Hydrocarbon comparison of the HFID for transient FTP test-1..................... 73

Figure 4.8 Hydrocarbon comparison of the HFID for transient FTP test-2..................... 73

Figure 4.9 A smaller time scale, an 150 second window, of the Hydrocarbon comparison

of the HFID analyzers for transient FTP test 1 ................................................. 74

Figure 4.10 Regression analysis of the HFID analyzers for transient FTP test-1............. 75

Figure 4.11 Regression analysis of the HFID analyzers for transient FTP test-2............. 76

Figure 4.12 Hydrocarbon comparison of the HFID for steady state 6-mode test- 1 . ........77

Figure 4.13 Hydrocarbon comparison of the HFID for steady state 6-mode test-2. ........78

Figure 4.14 Regression analysis of the HFID for steady state 6-mode test-1................. 79

Figure 4.15 Regression analysis of the HFID for steady state 6-mode test-2................. 79

Figure 4.16 Flow comparison of the V-Cone and Annubar ${ }^{\circledR}$ for steady state test- $01 . \ldots . .82$

Figure 4.17 Differential pressures for the V-Cone and Annubar ${ }^{\circledR}$ for steady state test- 01 . 
Figure 4.18 Flow comparison between the V-Cone and Annubar ${ }^{\circledR}$ for steady state test-02

Figure 4.19 Flow comparison between the V-Cone and Annubar ${ }^{\circledR}$ for transient test of the dozer cycle.

Figure 4.20 Differential pressures for the V-Cone and Annubar ${ }^{\circledR}$ transducers for the transient test of the dozer cycle.

Figure 4.21 Flow schematic of the EERL test cell, with both the MEMS systems and flow meters in- line with the exhaust.

Figure 4.22 Flow rate comparison for the V-Cone andAnnubar ${ }^{\circledR}$ for transient test

VolvoPA1-01.

Figure 4.23 Flow rate comparison for the V-Cone and Annubar ${ }^{\circledR}$ for steady state test VolvoSS2-01...

Figure 4.24 Regression analysis for flow rates between the V-Cone and Annubar ${ }^{\circledR}$ for transient test VolvoPA1-01.

Figure 4.25 Regression analysis for flow rates between the V-Cone and Annubar ${ }^{\circledR}$ for steady state test VolvoSS2-01.

Figure 4.26 Differential pressures for the Annubar ${ }^{\circledR}$ and V-cone for steady state test VolvoSS2-01.

Figure 4.27 Exhaust temperature comparison at the location of the V-Cone and Annubar ${ }^{\circledR}$

for steady state test.

Figure 4.28 Flow rate comparison for the V-Cone and Annubar ${ }^{\circledR}$ for transient test

VolvoPA1-04 before time alignment.

Figure 4.29 Regression analysis for transient test VolvoPA1-04 before time alignment.

Figure 4.30 Flow rate comparison for the V-Cone and Annubar ${ }^{\circledR}$ for transient test

VolvoPA1-04 after time alignment.

Figure 4.31 Regression analysis for transient test VolvoPA1-04 after time alignment.. 101

Figure 4.32 $\mathrm{NO}_{\mathrm{X}}$ mass emissions rate comparison between the V-Cone, Annubar ${ }^{\circledR}$, and

Laboratory, transient test VolvoPA1-01.

Figure 4.33 $\mathrm{NO}_{\mathrm{X}}$ mass emissions rate comparison between the V-Cone, Annubar ${ }^{\circledR}$, and

Laboratory, transient test VolvoPA1-04.

Figure 4.34 $\mathrm{NO}_{\mathrm{X}}$ mass emissions rate comparison between the V-Cone, Annubar ${ }^{\circledR}$, and

Laboratory, transient test VolvoPA1-05.

Figure 4.35 $\mathrm{NO}_{\mathrm{X}}$ mass emissions rate comparison between the V-Cone, Annubar ${ }^{\circledR}$, and

Laboratory, steady state test VolvoSS2-01............................................. 104

Figure 4.36 Regression analysis for $\mathrm{NO}_{\mathrm{X}}$ for test VolvoPA1-01. ............................... 105

Figure 4.37 Regression analysis for $\mathrm{NO}_{\mathrm{X}}$ for test VolvoSS2-01................................ 106

Figure $4.38 \mathrm{CO}_{2}$ emissions mass emissions rate comparison between the V-Cone,

Annubar $^{\circledR}$, and Laboratory, transient test VolvoPA1-01............................. 108

Figure $4.39 \mathrm{CO}_{2}$ mass emissions rate comparison between the V-Cone, Annubar ${ }^{\circledR}$, and

Laboratory, transient test VolvoPA1-04.

Figure $4.40 \mathrm{CO}_{2}$ mass emissions rate comparison between the V-Cone, Annubar ${ }^{\mathbb{B}}$, and

Laboratory, transient test VolvoSS2-01.

Figure $4.41 \mathrm{CO}_{2}$ regression analysis for test VolvoPA1-01.

Figure $4.42 \mathrm{CO}_{2}$ regression analysis for test VolvoSS2-01.... 
Figure 8.1 Hydrocarbon comparison of the HFID for transient FTP test-1 $1 . \ldots \ldots \ldots \ldots \ldots . . . . . . .124$

Figure 8.2 Regression analysis of the HFID analyzers for transient FTP test-1........... 124

Figure 8.3 Percent difference of the HFID analyzers for transient FTP test-1............. 125

Figure 8.4 Hydrocarbon comparison of the HFID for transient FTP test-2 2.................. 125

Figure 8.5 Regression analysis of the HFID analyzers for transient FTP test-2........... 126

Figure 8.6 Percent difference of the HFID analyzers for transient FTP test-2 .............. 126

Figure 8.7 Hydrocarbon comparison of the HFID for steady state 6-mode test-1....... 127

Figure 8.8 Regression analysis of the HFID for steady state 6 -mode test- 1 .................. 127

Figure 8.9 Percent difference of the HFID for steady state 6 -mode test-1.................... 128

Figure 8.10 Hydrocarbon comparison of the HFID for steady state 6-mode test-2 ...... 128

Figure 8.11 Regression analysis of the HFID for steady state 6-mode test-2................ 129

Figure 8.12 Percent difference of the HFID for steady state 6-mode test-2 ................. 129

Figure 8.13 Hydrocarbon comparison of the HFID for the T90 response test. ............. 130

Figure 8.14 Hydrocarbon comparison of the HFID for the zero air drift test................ 130

Figure 8.15 Hydrocarbon comparison of the HFID for the span gas drift test. .............. 131

Figure 8.16 Flow rate comparison of the V-Cone and Annubar ${ }^{\circledR}$ for transient test

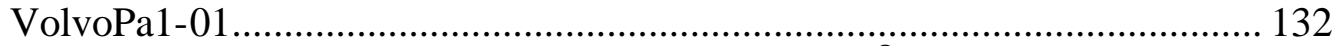

Figure 8.17 Flow rate comparison of the V-Cone and Annubar ${ }^{\circledR}$ for transient test

VolvoPa1-02 ................................................................................... 133

Figure 8.18 Flow rate comparison of the V-Cone and Annubar ${ }^{\circledR}$ for transient test

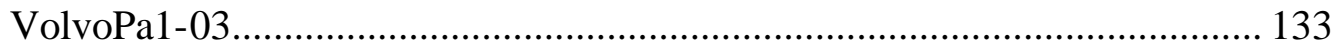

Figure 8.19 Flow rate comparison of the V-Cone and Annubar ${ }^{\circledR}$ for transient test

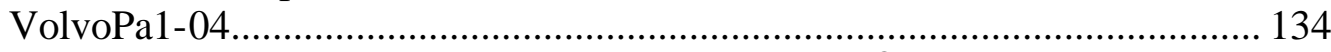

Figure 8.20 Flow rate comparison of the V-Cone and Annubar ${ }^{\circledR}$ for transient test

VolvoSS2-01 ............................................................................. 134

Figure 8.21 Flow rate comparison of the V-Cone and Annubar ${ }^{\circledR}$ for transient test

VolvoSS2-02.

Figure 8.22 Flow rate comparison of the V-Cone and Annubar ${ }^{\circledR}$ for transient test

VolvoSS2-03.

Figure 8.23 Flow rate regression analysis for the V-Cone and Annubar ${ }^{\circledR}$ for transient test

VolvoPA1-01.

Figure 8.24 Flow rate regression analysis for the V-Cone and Annubar ${ }^{\circledR}$ for transient test

VolvoPA1-02.

Figure 8.25 Flow rate regression analysis for the V-Cone and Annubar ${ }^{\circledR}$ for transient test

VolvoPA1-03.

Figure 8.26 Flow rate regression analysis for the V-Cone and Annubar ${ }^{\circledR}$ for transient test VolvoPA1-04.

Figure 8.27 Flow rate regression analysis for the V-Cone and Annubar ${ }^{\circledR}$ for transient test

VolvoSS2-01.

Figure 8.28 Flow rate regression analysis for the V-Cone and Annubar ${ }^{\circledR}$ for transient test

VolvoSS2-02.

Figure 8.29 Flow rate regression analysis for the V-Cone and Annubar ${ }^{\circledR}$ for transient test

VolvoSS2-03.

Figure 8.30 Exhaust temperature comparison of the V-Cone and Annubar ${ }^{\circledR}$. 139 
Figure 8.31 $\mathrm{NO}_{\mathrm{X}}$ mass emissions rates comparison between the V-Cone, Annubar ${ }^{\circledR}$, and

Laboratory mass emissions rates, transient test VolvoPA1-01.

Figure 8.32 $\mathrm{NO}_{\mathrm{X}}$ mass emissions rates comparison between the V-Cone, Annubar ${ }^{\circledR}$, and

Laboratory mass emissions rates, transient test VolvoPA1-02. 141

Figure 8.33 $\mathrm{NO}_{\mathrm{X}}$ mass emissions rates comparison between the V-Cone, Annubar ${ }^{\circledR}$, and

Laboratory mass emissions rates, transient test VolvoPA1-03. 141

Figure $8.34 \mathrm{NO}_{\mathrm{X}}$ mass emissions rates comparison between the V-Cone, Annubar ${ }^{\circledR}$, and

Laboratory mass emissions rates, transient test VolvoPA1-04. 142

Figure 8.35 $\mathrm{NO}_{\mathrm{X}}$ mass emissions rates comparison between the V-Cone, Annubar ${ }^{\circledR}$, and

Laboratory mass emissions rates, transient test VolvoSS2-01..................... 142

Figure 8.36 $\mathrm{NO}_{\mathrm{X}}$ mass emissions rates comparison between the V-Cone, Annubar ${ }^{\circledR}$, and

Laboratory mass emissions rates, transient test VolvoSS2-02. 143

Figure $8.37 \mathrm{NO}_{\mathrm{X}}$ mass emissions rates comparison between the $\mathrm{V}-\mathrm{Cone}$, Annubar ${ }^{\circledR}$, and

Laboratory mass emissions rates, transient test VolvoSS2-03 143

Figure 8.38 $\mathrm{NO}_{\mathrm{X}}$ mass emissions rates comparison between the V-Cone, Annubar ${ }^{\circledR}$, and

Laboratory mass emissions rates, transient test VolvoPA1-05.................... 144

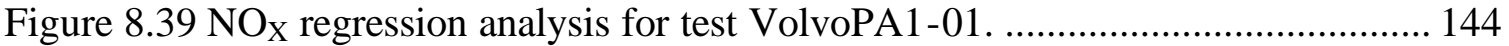

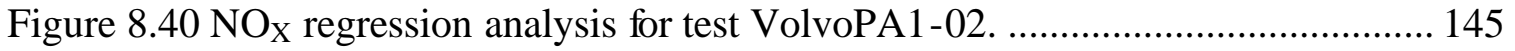

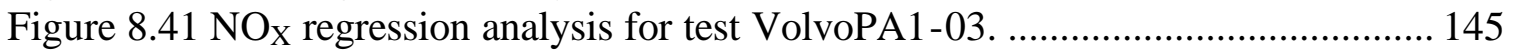

Figure $8.42 \mathrm{NO}_{\mathrm{X}}$ regression analysis for test VolvoPA1-04. ..................................... 146

Figure 8.43 $\mathrm{NO}_{\mathrm{X}}$ regression analysis for test VolvoSS2-01....................................... 146

Figure 8.44 $\mathrm{NO}_{\mathrm{X}}$ regression analysis for test VolvoSS2-02...................................... 147

Figure $8.45 \mathrm{NO}_{\mathrm{X}}$ regression analysis for test VolvoSS2-03...................................... 147

Figure $8.46 \mathrm{CO}_{2}$ mass emissions rates comparison between the V-Cone, Annubar ${ }^{\circledR}$, and

Laboratory mass emissions rates, transient test VolvoPA1-01................... 148

Figure $8.47 \mathrm{CO}_{2}$ mass emissions rates comparison between the V-Cone, Annubar ${ }^{\circledR}$, and

Laboratory mass emissions rates, transient test VolvoPA1-02.

Figure $8.48 \mathrm{CO}_{2}$ mass emissions rates comparison between the V-Cone, Annubar ${ }^{\circledR}$, and

Laboratory mass emissions rates, transient test VolvoPA1-03.................... 149

Figure $8.49 \mathrm{CO}_{2}$ mass emissions rates comparison between the V-Cone, Annubar ${ }^{\circledR}$, and

Laboratory mass emissions rates, transient test VolvoPA1-04.

Figure 8.50 $\mathrm{CO}_{2}$ mass emissions rates comparison between the V-Cone, Annubar ${ }^{\circledR}$, and

Laboratory mass emissions rates, transient test VolvoSS2-01.................... 150

Figure $8.51 \mathrm{CO}_{2}$ mass emissions rates comparison between the V-Cone, Annubar ${ }^{\circledR}$, and

Laboratory mass emissions rates, transient test VolvoSS2-02.....

Figure $8.52 \mathrm{CO}_{2}$ mass emissions rates comparison between the V-Cone, Annubar ${ }^{\circledR}$, and

Laboratory mass emissions rates, transient test VolvoSS2-03.................... 151

Figure $8.53 \mathrm{CO}_{2}$ regression analysis for test VolvoPA1-01.................................... 152

Figure $8.54 \mathrm{CO}_{2}$ regression analysis for test VolvoPA1-02. ................................... 152

Figure $8.55 \mathrm{CO}_{2}$ regression analysis for test VolvoPA1-03. ..................................... 153

Figure $8.56 \mathrm{CO}_{2}$ regression analysis for test VolvoPA1-04. ...................................... 153

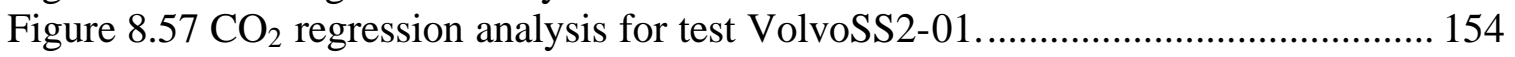

Figure $8.58 \mathrm{CO}_{2}$ regression analysis for test VolvoSS2-02 ..................................... 154

Figure $8.59 \mathrm{CO}_{2}$ regression analysis for test VolvoSS2-03................................... 155 


\section{LIST OF TABLES}

Table 1.1 1998 Emissions standards for heavy-duty diesel engines, g/bhp-hr................. 1

Table 1.2 Options for certification of heavy-duty diesel engines for 2004 and later

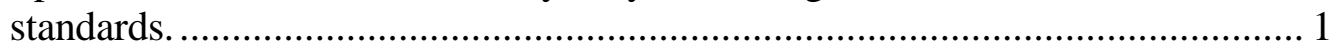

Table 2.1 Emissions equipment used in the CE-CERT Mobile Laboratory [40]............ 10

Table 2.2 Flow meter rankings for permanent pressure loss. ...................................... 23

Table 2.3 Applications, and the Industry where applied, for the V-Cone. ..................... 24

Table 3.1 Nomenclature of the V-Cone flow rate calculation. .....................................50

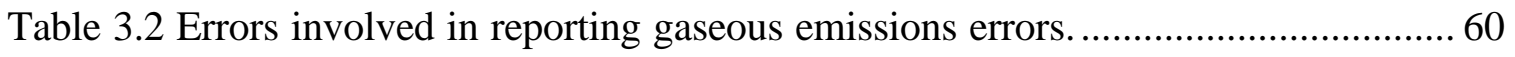

Table 3.3 Speed and load set points for the VolvoSS2 test cycle. .................................66

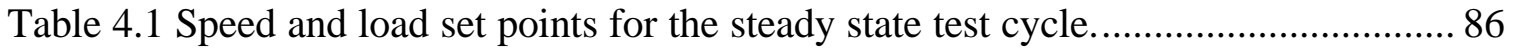

Table 4.2 Nomenclature for dry to wet conversion. ..................................................... 91

Table 4.3 Integrated $\mathrm{NO}_{\mathrm{X}}$ mass rates comparison of the $\mathrm{V}$-Cone, Annubar ${ }^{\circledR}$, and Laboratory with percent difference of the V-Cone and Annubar ${ }^{\circledR}$ with the Laboratory for all transient and steady state tests. .................................... 107

Table 4.4 Integrated $\mathrm{CO}_{2}$ mass emissions rates comparison of the V-Cone, Annubar ${ }^{\circledR}$, and Laboratory with percent difference of the V-Cone and Annubar ${ }^{\circledR}$ with the Laboratory for all transient and steady state tests. ...................................... 110

Table 4.5 Differences between the measured V-Cone and the measured Annubar ${ }^{\circledR}$ mass

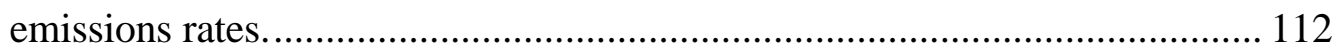

Table 4.6 Differences between the V-Cone with corrected values and the measured Annubar $^{\circledR}$ mass emissions rates. .............................................................. 112

Table 4.7 Percent differences between the corrected V-Cone and Annubar ${ }^{\circledR}$ mass emissions rates with the Laboratory values. The corrected V-Cone corrects to the Annubar ${ }^{\circledR}$ data, not the Laboratory data.

Table 4.8 Percent difference of integrated values comparing the V-Cone and Annubar ${ }^{\circledR}$ mass emissions rates, without correcting the V-Cone values to the Annubar ${ }^{\circledR}$ values, to the Laboratory values.

Table 4.9 Percent differences between the corrected V-Cone values and the measured Annubar ${ }^{\circledR}$ values of mass emissions rates using the average slope of the steady state test regression. 


\section{NOMENCLATURE}

$\begin{array}{ll}\text { ADC } & \text { Analog to Digital Converter } \\ \text { ACFM } & \text { Actual Cubit Feet per Minute } \\ \text { CARB } & \text { California Air Resources Board } \\ \text { CFR } & \text { Code of Federal Regulations } \\ \text { CFV-CVS } & \text { Critical Flow Venturi-Constant Volume Sampler } \\ \mathrm{CO} & \text { Carbon Monoxide } \\ \mathrm{CO}_{2} & \text { Carbon Dioxide } \\ \text { ECM } & \text { Engine Control Module } \\ \text { ECU } & \text { Engine Control Unit } \\ \text { EERL } & \text { Engine and Emissions Research Laboratory } \\ \text { EPA } & \text { Environmental Protection Agency } \\ \text { FID } & \text { Flame Ionization Detector } \\ \text { g } & \text { Grams } \\ \text { g/bhp·hr } & \text { Grams per brake-horsepower hour } \\ \mathrm{HC} & \text { Hydrocarbons } \\ \mathrm{HDDE} & \text { Heavy-Duty Diesel Engine } \\ \mathrm{HFID} & \text { Heated Flame Ionization Detector } \\ \mathrm{Hp} & \text { Horsepower } \\ \mathrm{MEMS} & \text { Mobile Emissions Measurement System } \\ \mathrm{NDIR} & \text { Non-Dispersive Infrared } \\ \mathrm{NMHC} & \text { Non-Methane Hydrocarbons } \\ \mathrm{NO} & \text { Nitric Oxide } \\ \mathrm{NO} & \text { Nitrogen Dioxide } \\ \mathrm{NO} & \text { Oxides of Nitrogen } \\ \mathrm{PM} & \text { Particulate Matter } \\ \text { ppm } & \text { Parts Per Million } \\ \mathrm{RPM} & \text { Revolutions Per Minute } \\ \mathrm{SCFM} & \text { Standard Cubic Feet per Minute } \\ \mathrm{SCFS} & \text { Standard Cubic Feet per Second } \\ \mathrm{WVU} & \text { West Virginia University } \\ & \end{array}$




\section{Chapter 1 INTRODUCTION}

In October 1997, the Environmental Protection Agency (EPA) adopted new emission standards for model year 2004 and later heavy-duty diesel truck and bus engines. These standards reflect the provisions of the Statement of Principles (SOP) signed in 1995 by the EPA, California Air Resources Board (ARB), and the manufacturers of heavy-duty diesel engines. The goal was to reduce $\mathrm{NO}_{\mathrm{X}}$ emissions from highway heavy-duty engines to levels approximately $2.0 \mathrm{~g} / \mathrm{bhp} \cdot \mathrm{hr}$ beginning in 2004 . Manufacturers have the flexibility to certify their engines to one of the two options shown in Table 1.2. All emission standards other than non-methane hydrocarbons (NMHC) and $\mathrm{NO}_{\mathrm{X}}$ applying to 1998 and later model year heavy duty engines will continue at their 1998 levels.

Table 1.1 1998 Emissions standards for heavy-duty diesel engines, g/bhp-hr.

\begin{tabular}{|l||l|l||l|l||}
\hline Heavy-Duty Diesel Truck Engines & HC & CO & NO $_{\mathrm{X}}$ & PM \\
\hline \hline 1998 & 1.3 & 15.5 & 4.0 & 0.10 \\
\hline \hline Urban Bus Engines & & & & \\
\hline \hline 1998 & 1.3 & 15.5 & 4.0 & 0.05 \\
\hline
\end{tabular}

Table 1.2 Options for certification of heavy-duty diesel engines for 2004 and later standards.

\begin{tabular}{|c||c||c|}
\hline Option & NMHC + NO & NMHC \\
\hline \hline 1 & 2.4 & $\mathrm{n} / \mathrm{a}$ \\
\hline \hline 2 & 2.5 & 0.5 \\
\hline
\end{tabular}


In October of 1998, a court settlement was reached between the EPA, Department of Justice, California ARB and engine manufacturers (Caterpillar, Cummins, Detroit Diesel, Volvo, Mack Trucks/Renault and Navistar) over the issue of high $\mathrm{NO}_{\mathrm{X}}$ emissions from heavy-duty diesel engines during certain driving modes. When the engines were tested for conformance with the emissions standards, the manufacturer would cause the ECU to operate in the "urban mode," which would allow the engine to pass the certification test. However, on road, the engine would produce greater emissions than the standards because the ECU would switch the engine to the "highway mode." Provisions of the Consent Decree included the following:

- Civil penalties for engine manufacturers and requirements to allocate funds for pollution research;

- Upgrading existing engines to lower $\mathrm{NO}_{\mathrm{X}}$ emissions;

- Certification of engines on both the transient FTP and the Supplemental SteadyState Test;

- Meeting the 2004 emission standards by October 2002, 15 months ahead of time.

From the consent decrees, the allocation of money to fund pollution research allowed institutions to develop realtime, on-board emissions measurement systems. WVU developed what they termed the MEMS system, a mobile, real-time emissions measurement system. WVU designed, fabricated, and tested the MEMS system, comparing the emissions data to their in-house Engine Emissions Research Laboratory (EERL). Extensive tests were conducted on the MEMS and the emissions sensors it 
used. The criteria for the sensors for MEMS were robustness, accuracy, and compactness. Also, different flow meters were tested and compared.

The MEMS system uses emissions sensors to measure $\mathrm{NO}_{\mathrm{X}}$ and $\mathrm{CO}_{2}$ concentrations from raw exhaust. Sample conditioning systems such as chillers were tested and integrated into MEMS to dry the sample stream prior to the sensors. Emissions of $\mathrm{CO}$ from diesel engines are at such low concentration levels that it was not considered as a target pollutant for MEMS. This decision was made in concurrence with the settling- Heavy Duty Diesel Engine Manufacturers (HDDE) and the EPA. The MEMS system was designed to be robust, to be able to handle on-road testing and the problems associated with on-road testing, such as vibration issues, temperature variation, humidity variations, etc.

The first generation MEMS was large and oversized approximately (24" by 24" by 12 "). It was more of a "bread board." The pumps were larger than they needed to be to ensure proper sampling; the $\mathrm{NO}_{\mathrm{X}}$ converter was purchased and therefore large and bulky. For the second generation MEMS, the $\mathrm{NO}_{\mathrm{X}}$ converter and the chiller were designed in-house to reduce their size and thus the size of MEMS. The second generation MEMS system was more compact, and the equipment was resized or redesigned to ensure the MEMS system didn't have any reductions in its capabilities.

Other engine emissions are produced by the engine but are not measured by MEMS. Possible reasons for not measuring them are the accuracy is poor for the sensors, the capability of instruments limits the applications of an on-board measurement system, or the emissions are produced in low concentrations such that they are negligible. 
As seen previously, the 2004 regulations require the measurement of $\mathrm{NO}_{\mathrm{X}}$ plus HC. Therefore, the measurement of hydrocarbons is involved for emissions measurements in the future. Any realtime, on-board emissions measurement system would need to measure hydrocarbons in addition to $\mathrm{NO}_{\mathrm{X}}$ for engines under the 2004 regulations. Therefore, there is a need for a portable hydrocarbon analyzer that is accurate and precise in its measurements during an on-board testing application. Currently, hydrocarbon analyzers are cumbersome and bulky, not suitable for on-board measurements.

Most flow meters need long straight pipe to ensure fully developed flow. Fully developed flow is needed for accurate flow rate measurements. The size of the pipe because of the dimensions of the pipe needed for fully developed flow is the limitation.

The objective of this study was to evaluate a portable flame ionization detector (FID) for the measurement of hydrocarbons and to evaluate a novel flow meter for infield, on-board emissions measurement. Also, in the scope of this study, is to investigate the integration of these instruments in to a mobile emissions measurement system. The portable hydrocarbon analyzer evaluated is Signal Groups Model 3030PM analyzer; and the flow meter evaluated is McCrometer's V-Cone.

The Signal Group developed a portable, heated flame ionizing detection (HFID) hydrocarbon analyzer (Model 3030PM) for portable hydrocarbon measurements and McCrometer developed the V-Cone, a flow measurement device that measures flow rates without the need for fully developed flow. 
The Signal Model 3030PM uses HFID technology to measure total HC. The analyzer is designed as a portable instrument; thus it was designed to be robust and compact for ease of transportation. Small gas bottles are included as well so that the FID fuel and span gases are also portable. Figure 1.1 shows the Signal Model 3030PM with the FID fuel and span gas bottle underneath.

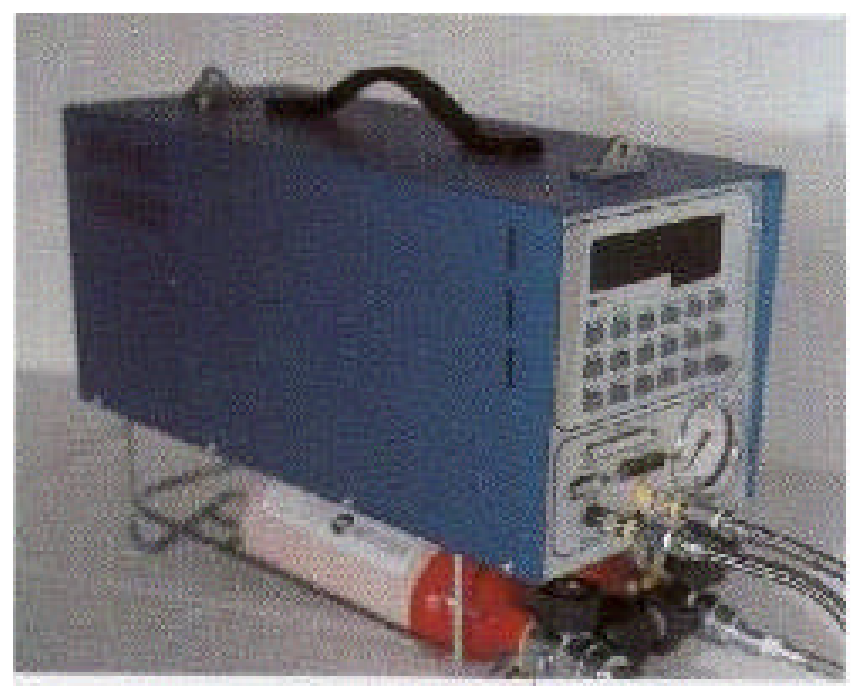

\section{Figure 1.1 Signal Model 3030PM portable hydrocarbon analyzer.}

McCrometer's V-Cone is an obstructive, differential pressure, flow measurement device that conditions the flow, eliminating the need for fully developed flow and the length of pipe associated with it. A conical mass located in the center of the flow profile forces the high velocity and low velocity flow to mix, conditioning the flow. Static pressure measurements are taken before the cone and on the downstream side of the cone, as can be seen in Figure 1.2. 


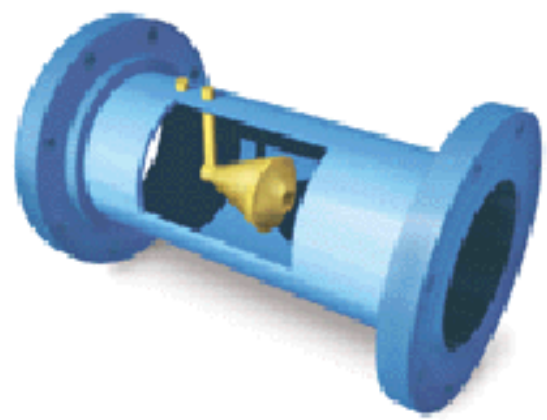

Figure 1.2 A cutout of the V-Cone showing the conical mass in the center of the flow, and the pressure ports. 


\section{Chapter 2 LITERATURE REVIEW}

\subsection{Introduction}

Actual emissions measurement in driving situations is becoming the accepted way to measure emissions. Previously, the engine was pulled from the vehicle and put into a test laboratory, operated through cycles trying to simulate real-world driving conditions, and the emissions were measured. In the real world, the driving conditions change constantly. In addition, humidity, temperature, pressures all are constantly changing. Therefore, the ability to measure emissions on-board vehicles is becoming more important. Therefore, new emphasis has gone into developing an accurate, on-board emissions measurement system to record real world emissions.

This chapter describes the steps that were taken to arrive at real-time, on-board emissions measurement. Other institutions have also developed and tested numerous systems, applying them to some aspect of on-board measurement. From the results and conclusions from these studies, new studies and new equipment were used to achieve greater accuracies for the measurement systems. The applications of this knowledge continue to expand and new systems are developed.

\subsection{In-Field Emissions Measurement}

\subsubsection{Southwest Research Institute}

Southwest Research Institute developed a system to test diesel engines in mining atmospheres between the years of 1978 to 1983 [5]. The system developed consisted of a portable engine dynamometer, laboratory-grade emissions instruments, volumetric fuel flow meter, and a laminar air meter. The emissions measurement instruments consisted 
of a heated ionizing flame detector (HFID) for hydrocarbons, a non-dispersive infrared (NDIR) for $\mathrm{CO}$ and $\mathrm{CO}_{2}$, a heated chemiluminescent analyzer (CLA) for $\mathrm{NO}_{\mathrm{X}}$, and a polar graphic analyzer for $\mathrm{O}_{2}$. Particulate matter was also measured using a mini-dilution tunnel. Calibrations needed to be done in the field, so the calibration gases were brought as part of the system.

The capabilities of this system were limited. The system was portable, but the level of portability for this system was low.

\subsubsection{Michigan Technological University}

Michigan Technological University researchers developed an Emissions Measurement Apparatus (EMA) system and reported results from underground mining equipment tests [8]. The EMA consisted of instruments to measure both PM and gaseous emissions. A dilute bag sampling system, a mini-dilution tunnel for gravimetric analysis of PM, battery powered portable emissions analyzers (for off-line bag analysis), and heated sample lines were used in the EMA.

Comparing the EMA system to laboratory grade instruments showed that the EMA was within $5 \%$ for $\mathrm{CO}_{2}$, within $10 \%$ for $\mathrm{CO}$, and within $5 \%$ for $\mathrm{NO}$. PM was within $7 \%$ of the laboratory grade instruments.

\subsubsection{University of Minnesota}

The University of Minnesota Researchers developed an emissions-assisted maintenance procedure (EAMP) for diesel-powered mining equipment B8]. A main design criterion for the EAMP system was portability. The EAMP was designed to be

more portable than the systems developed by Southwest Research Institute or Michigan 
Technological University, and was designed to detect engine faulting. Electrochemical gas sensor (EGS) technology was determined to be a rugged and portable technology. The sensor accuracy was determined to be $5 \%$ of the measured value of $\mathrm{NO}, \mathrm{NO}_{2}, \mathrm{CO}$, $\mathrm{CO}_{2}$, and $\mathrm{O}_{2}$.

Comparing the EAMP with laboratory grade instruments showed that, for a diesel engine on a dynamometer, the Ecom-AC analyzer emissions reading were within 5\%. The Ecom AC analyzer was slightly higher than the laboratory grade instruments. A curve fit to known gases was employed to minimize the analyzer measurement errors.

\subsubsection{University of California, Riverside}

The University of California, Riverside, Bournes College of Engineering-Center for Environmental Research and Technology (CE-CERT) has developed a Mobile OnRoad Heavy-Duty Emissions Laboratory. The centerpiece of the Emissions Laboratory is a 53-foot insulated trailer in which CE-CERT has installed analytical equipment for measurement of gaseous and particulate emissions from the tractor's exhaust stack. Like an emissions laboratory (and unlike other portable systems), the trailer is equipped with the analytical instrumentation necessary to accurately measure emissions in grams per mile and appropriate atmospheric conditions [40]. The Laboratory consists of instruments to measure $\mathrm{NO}_{\mathrm{X}}, \mathrm{HC}, \mathrm{CO}, \mathrm{CO}_{2}$, methane, and total particulate matter. The laboratory grade emissions instruments used in the trailer are listed in Table 2.1. 
Table 2.1 Emissions equipment used in the CE-CERT Mobile Laboratory [40].

\begin{tabular}{|c|c|c|c|c|c|c|}
\hline Parameter & $\begin{array}{l}\text { Instrument } \\
\text { Model }\end{array}$ & $\begin{array}{l}\text { Detection } \\
\text { Method }\end{array}$ & Operating Ranges & Sensitivity & $\begin{array}{l}\text { Response } \\
\text { Time }\end{array}$ & $\begin{array}{l}\text { Sample Flow } \\
\text { and } \\
\text { Pressure }\end{array}$ \\
\hline \multirow[t]{2}{*}{$\begin{array}{l}\text { Hydro } \\
\text { carbons } \\
\end{array}$} & $\begin{array}{l}\text { Horiba FIA- } \\
34 \mathrm{~A}\end{array}$ & "Flame lonization & $\begin{array}{l}0-10 / 100 / 500 / 1000 \mathrm{ppm} \\
\mathrm{C} 1 \text { standard }\end{array}$ & "0.5\% full scale & $.5 \mathrm{sec}$ to $90 \%$ & $3 \mathrm{lpm}$ \\
\hline & $\begin{array}{l}\text { Horiba } \\
\text { OPE-415 }\end{array}$ & & $\begin{array}{l}\text { optional ranges to } 30,000 \\
\text { ppm C1 }\end{array}$ & (0.05 ppm-C1) & & at 3" HG \\
\hline \multirow[t]{5}{*}{$\begin{array}{l}\text { Oxides of } \\
\text { Nitrogen }\end{array}$} & $\begin{array}{l}\text { Horiba } \\
\text { CLA22A } \\
\end{array}$ & $\begin{array}{l}\text { Chemiluminesce } \\
\mathrm{nt}\end{array}$ & 0 to $10 / 25 / 100 / 400 \mathrm{ppm}$ & 0.5\% full scale & $\begin{array}{l}3 \text { sec for } \mathrm{NO}< \\
10 \mathrm{ppm}\end{array}$ & "5lpm @ 6 psig \\
\hline & $\begin{array}{l}\text { Horiba } \\
\text { OPE-235 } \\
\end{array}$ & & & & $\begin{array}{l}2 \text { sec for } \mathrm{NO}> \\
10 \mathrm{ppm} \\
\end{array}$ & \\
\hline & $\begin{array}{l}\text { Horiba } \\
\text { OZG-UV-01 }\end{array}$ & & & & & \\
\hline & $\begin{array}{l}\text { Horiba } \\
\text { COM-11-HRB }\end{array}$ & & & & & \\
\hline & $\begin{array}{l}\text { Horiba } \\
\text { GC-12 }\end{array}$ & & & & & \\
\hline \multirow[t]{2}{*}{$\begin{array}{l}\text { Carbon } \\
\text { Monoxide }\end{array}$} & $\begin{array}{l}\text { Horiba } \\
\text { CFA-26 }\end{array}$ & $\begin{array}{l}\text { Nondispersive } \\
\text { Infrared }\end{array}$ & $\begin{array}{l}0-50 / 250 / 1,000 / 5,000 \\
\text { ppm }\end{array}$ & $0.5 \%$ full scale & $\begin{array}{l}2 \text { seconds to } \\
90 \%\end{array}$ & "5 lpm \\
\hline & $\begin{array}{l}\text { Horiba } \\
\text { OPE-144 }\end{array}$ & $\begin{array}{l}\text { Optical filter, } \\
\text { dual-source gas- } \\
\text { filled capacitive } \\
\text { detector }\end{array}$ & & & & \\
\hline \multirow[t]{2}{*}{$\begin{array}{l}\text { Carbon } \\
\text { Dioxide } \\
\end{array}$} & $\begin{array}{l}\text { Horiba } \\
\text { AIA-23 } \\
\end{array}$ & $\begin{array}{l}\text { Nondispersive } \\
\text { Infrared }\end{array}$ & "0-0.5/2/8/16 percent & "0.5\% full scale & 0.5 to $15.5 \mathrm{sec}$ & $2 \mathrm{Ilpm}$ \\
\hline & $\begin{array}{l}\text { Horiba } \\
\text { OPE-135 }\end{array}$ & "Flow modulation & & & & \\
\hline Methane & $\begin{array}{l}\text { Pierburg } \\
\text { PM } 2000\end{array}$ & $\begin{array}{l}\text { Flame lonization } \\
\text { thermo- chemical } \\
\text { converter for } \\
\text { oxidizing HC's } \\
\text { with C-C bonds }\end{array}$ & "0-10 to 10,000 ppm C1 & $1 \%$ of full scale & 5 seconds & 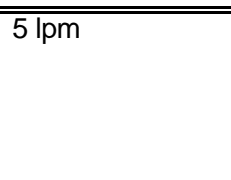 \\
\hline \multirow[t]{2}{*}{$\begin{array}{l}\text { Dew Point } \\
\text { Tunnel }\end{array}$} & $\begin{array}{l}\text { General } \\
\text { Eastern } \\
\text { HYGRO-M1 } \\
\end{array}$ & Chilled Mirror & $\begin{array}{l}-10 \text { to }+85 \text { degrees } \\
\text { Celsius }\end{array}$ & $+/-0.03 \operatorname{deg} C$ & "<7 seconds for & $1 \mathrm{elpm}$ \\
\hline & $\begin{array}{l}\text { General } \\
\text { Eastern SIM- } \\
12 \mathrm{H}\end{array}$ & $\begin{array}{l}\text { Heated case } \\
\text { sensor }\end{array}$ & & & $\begin{array}{l}45^{\circ} \mathrm{C} \text { step } \\
\text { change }\end{array}$ & \\
\hline \multirow[t]{2}{*}{$\begin{array}{l}\text { Dew Point/ } \\
\text { Temperature } \\
\text { Ambient } \\
\end{array}$} & $\begin{array}{l}\text { General } \\
\text { Eastern } \\
\text { 1200MPS } \\
\end{array}$ & Chilled Mirror & $\begin{array}{l}-50 \text { to }+50 \text { degrees } \\
\text { Celsius }\end{array}$ & + +/-0.03 deg C & & $=1 \mathrm{lpm}$ \\
\hline & $\begin{array}{l}\text { General } \\
\text { Eastern } \\
1211 \mathrm{HX} \\
\end{array}$ & $\begin{array}{l}\text { Platinum RTD } \\
\text { temperature }\end{array}$ & $\begin{array}{l}-50 \text { to }+50 \text { degrees } \\
\text { Celsius }\end{array}$ & & & \\
\hline $\begin{array}{l}\text { Barometric } \\
\text { Pressure } \\
\end{array}$ & $\begin{array}{l}\text { Vaisala } \\
\text { PTB101B } \\
\end{array}$ & silicon capacitive & 600 to $1060 \mathrm{hPa}$ & $+/-0.1 \mathrm{hPA}$ & "0.3 seconds & $\mathrm{N} / \mathrm{A}$ \\
\hline Position & Garmin III Plus & $\begin{array}{l}\text { Global } \\
\text { Positioning } \\
\text { System } \\
\text { DCI RDS } 3000\end{array}$ & $\begin{array}{l}3 \text { axis position plus } \\
\text { velocity } \\
\text { FM receiver of correction } \\
\text { info. } \\
\text { with differential } \\
\text { for horiz. axes }\end{array}$ & $\begin{array}{l}+/-10 \text { meters } \\
+/-1 \text { meter }\end{array}$ & $\begin{array}{l}2 \text { second } \\
\text { update }\end{array}$ & $\overline{\mathrm{N} / \mathrm{A}}$ \\
\hline $\begin{array}{l}\text { Vehicle } \\
\text { Parameters }\end{array}$ & $\begin{array}{l}\text { Dearborn } \\
\text { Group } \\
\text { DG-DPA It-RS }\end{array}$ & $\begin{array}{l}\text { Access to vehicle } \\
\text { J1708,CAN, etc. } \\
\text { network }\end{array}$ & $\begin{array}{l}\text { full range of transmitted } \\
\text { data }\end{array}$ & $\mathrm{N} / \mathrm{A}$ & $\mathrm{N} / \mathrm{A}$ & $\overline{N \mathrm{~N} / \mathrm{A}}$ \\
\hline
\end{tabular}




\subsection{On-Board Measurements}

\subsubsection{Caterpillar Inc.}

Caterpillar developed a portable bag collection system to quantify fuel specific $\mathrm{NO}_{\mathrm{X}}$ emission level from in-use diesel engines [14]. The system consisted of two dilution bags where the water vapor was removed from the sample stream before entering the bags. The system was powered by an on-board supply. The system was portable enough that the driver could operate the system while driving.

The size of the system was about the size of a small suitcase. Comparing the portable bag collection sys tem with laboratory grade instruments showed that the system was within $10 \%$ for concentrations measured in ppm. This system showed that collecting on-board fuel specific data was possible.

\subsubsection{Southwest Research Institute}

A portable system was developed at Southwest Research Institute to measure exhaust emissions from diesel buses and to compare the data against the EPA's data base of transient engine emissions [21]. This system was designed to collect emissions data without using a chassis dynamometer. Test cycles were developed to run the engine while the vehicle was parked. Cycles included idles, no-load testing to loading the engine against the transmission through accelerator pedal set points. Only automatic transmission vehicles could be used.

An Energy Efficiency Systems, Inc. Enerac 2000E was used to measure raw emissions, $\mathrm{CO}, \mathrm{CO}_{2}, \mathrm{NO}_{\mathrm{X}}$, and $\mathrm{O}_{2}$ from a bag sample. PM was measured using a mini- 
dilution tunnel. The size of this system was about the size of a suitcase. Comparing the Enerac 2000E with laboratory grade instruments showed that the Enerac 2000E was within $5 \%$.

\subsubsection{General Motors}

General Motors outfitted a 1989 gasoline fueled passenger vehicle with emissions instrumentation and was driven by the researchers through city and highway routes to obtain real-world emissions data [30]. The instrumentation for this study weighed $400 \mathrm{lbs}$ and consisted of five 12-volt batteries, inverters, computers, and five different emissions analyzers. The gaseous emissions being measured and their analyzers were $\mathrm{CO}_{2}$ and hydrocarbons (Horiba Mexa 311GE), CO and hydrocarbons (Horiba Mexa 324GE), CO and hydrocarbons (Siemens Ultramat 22P), NO (Siemens analyzer), and ambient CO (Draeger analyzer). The redundant $\mathrm{CO}$ and $\mathrm{HC}$ measurements were made in order to measure different levels of concentration.

The exhaust flow rate was inferred from the intake flow rate. The exhaust flow rates, taken by a Kurz flow meter, were correlated with the intake flow rates, which were derived from stock mass flow meter signals.

\subsubsection{Ford Motor Company}

A series of reports from Ford Motor Company detail the emissions results from three different gasoline-fueled passenger vehicles [6, 18, 32, and 34]. An on-board emissions (OBE) system was housed in an Aerostar van for these tests. The OBE consisted of an FTIR and a dilution tunnel. There were two aspects of comparing this OBE system. The first was a comparison of the systems for a vehicle operated on a 
chassis dynamometer. The second was an on-road test. When the OBE was compared to Horiba laboratory grade instruments, for the dynamometer testing, it showed that the OBE was within (on average) $2 \%$ for $\mathrm{CO}_{2}, 3 \%$ for $\mathrm{CO}, 10 \%$ for $\mathrm{NO}_{\mathrm{X}}$, and $7 \%$ for $\mathrm{HC}$. For the on-road tests, the $\mathrm{OBE}$ was within (on average) $10 \%$ for $\mathrm{CO}, 1 \%$ for $\mathrm{CO}_{2}, 6.6 \%$ for $\mathrm{NO}_{\mathrm{X}}$, and $1 \%$ for $\mathrm{HC}$.

Also a Ford Taurus was instrumented with infrared-based analyzers (manufactured by MPSI) for measuring $\mathrm{CO}, \mathrm{CO}_{2}, \mathrm{HC}$, and $\mathrm{O}_{2}$, and an unspecified fast response non-dispersive ultraviolet (NDUV) system. The fast response NDUV system had a response of 1.1 seconds for measuring NO. Laboratory grade instruments were compared to the on-board NDIR analyzer for measuring NO. A correlation o 0.97 with a slope of 0.8 was found between the NDUV and chemiluminescent instruments.

\subsubsection{U.S. Coast Guard}

A 1992 SAE technical paper and a 1997 report describe the on-board emissions testing of a U.S. Coast Guard Cutter for non-road emissions as part of the 1990 Clean Air Act $[3,4]$. The emissions measured for these reports were $\mathrm{CO}, \mathrm{CO}_{2}, \mathrm{NO}, \mathrm{NO}_{2}, \mathrm{SO}_{2}, \mathrm{O}_{2}$, and HC. An Enerac 2000E was used to measure all gaseous emissions except $\mathrm{CO}_{2} \cdot \mathrm{CO}_{2}$ was inferred from the measured emissions. The monitoring system incorporated air and fuel flow measurements and provided for inference of engine-out torque via driveshaftmounted strain gauges.

\subsubsection{University of Pittsburgh}

An on-board emissions measurement system for I/M was developed for natural gas-powered passenger van at the University of Pittsburgh [39]. $\mathrm{HC}, \mathrm{CO}, \mathrm{CO}_{2}, \mathrm{NO}$, and 
$\mathrm{O}_{2}$ were measured using a RG240 five-gas analyzer from OTC SPX. Engine data was recorded using the on-board diagnostic equipment. The emissions measurement instruments were designed for gasoline fueled vehicles, therefore some results are biased.

\subsubsection{VITO, The Flemish Institute for Technological Research}

Vito, the Flemish Institute for Technological Research, performed on-board emissions measurements using the emissions measurement system they developed, VEOM (Vito's on-the-road emissions and energy measurement system). NDIR analyzers were used for gaseous measurements of $\mathrm{CO}_{2}$ and $\mathrm{CO}$, an FID was used for hydrocarbon concentrations, and a chemiluminescent analyzer was used to measure NO. A nitrogendriven injector was used to draw a sample of the exhaust from the tailpipe and dilute it to prevent water condensation. Heated sample lines were used to prevent the loss of hydrocarbons for diesel engine tests. Tests were conducted on both gasoline and diesel fueled vehicles. The partial dilute exhaust measurements were combined with fuel consumption, engine speed, and lambda value determination in order to present gaseous emissions on a $\mathrm{g} / \mathrm{km}$ and $\mathrm{g} / \mathrm{s}$ basis.

The system, when compared on a fixed chassis dynamometer, was within $10 \%$ for all emissions except $20 \%$ for $\mathrm{CO}$ and $25 \%$ for $\mathrm{HC}$ for the diesel engine testing.

\subsubsection{Northeast States for Coordinated Air Use Management}

A study by the Northeast States for Coordinated Air Use Management (NESCAUM) evaluated in-use emissions from diesel-powered off-road construction vehicles and explored the effects of various emissions control devices [9]. The system that they used was comprised of a computer controlled sampling system, a mini-dilution 
tunnel, heated lines, and a MPSI five-gas portable gas analyzer to measure emissions, a Tedlar bag, and a filter for PM measurement. The emissions analysis was found to be unreliable. There was a $27 \%$ difference between the system and laboratory collections.

\subsubsection{Office of Mobile Sources: USEPA}

The Office of Mobile Sources at the US EPA has developed a mobile measurement system called Rover. Rover was developed for light-duty vehicles with some experimentation into heavy duty vehicles. The Rover system uses NDIR to measure $\mathrm{CO}, \mathrm{CO}_{2}$, and $\mathrm{HC}$, and electrochemical cells to measure $\mathrm{O}_{2}$ and $\mathrm{NO}$ concentrations, and an Annubar ${ }^{\circledR}$ with differential pressure sensor is used for exhaust

flow measurement. Vehicle speed and distance was measured by either the ECM or a GPS (global positioning system) [36].

\subsubsection{Ford Motor Company and WPI-Microprocessor Systems, Inc}

Ford Motor Company and WPI-Microprocessor Systems, Inc. are developing/have developed a Portable RealTime Emissions Vehicular Integrated Engineering Workstation (PREVIEW) that will sample water-laden exhaust [7]. The design of PREVIEW is for it to be a totally integrated, portable system that measures the exhaust masses of $\mathrm{CO}, \mathrm{CO}_{2}, \mathrm{NO}$, and $\mathrm{HC}$. Testing has shown that for gasoline powered vehicles in a light duty chassis dynamometer laboratory, PREVIEW was within $1.5 \%$ for $\mathrm{CO}_{2}, 3.4 \%$ for $\mathrm{CO}, 12.3 \%$ for $\mathrm{HC}$ (comparing NDIR to a FID), and $0.4 \% \mathrm{NO}_{\mathrm{X}}$.

\subsubsection{Horiba Inc. and NGK Insulators, Ltd}

Horiba Inc. and NGK Insulator, Ltd. have developed an on-board $\mathrm{NO}_{\mathrm{X}}$ emissions measurement system for diesel vehicles [31]. The system consists of a zirconium oxide 
$\left(\mathrm{ZrO}_{2}\right)$ sensor, Karman vortex volumetric flow meter for intake air flow, and sensors for intake air pressures, intake air temperatures, intake air relative humidity, boost pressure, ambient pressure, ambient temperature, vehicle velocity, engine rpm, and coolant temperature. This system has shown that it is within $4 \% \mathrm{NO}_{\mathrm{X}}, 3 \%$ fuel consumption, and $1 \%$ for distance measurements.

\subsubsection{Honda R\&D}

Honda R\&D Americas, Ltd.; Honda R\&D Co., Ltd.; and Nocolet Instrument Corp. have presented work on an FTIR-based system for measuring real-world emissions from light-duty gasoline vehicles [28]. The emissions that are targeted are non-methane hydrocarbons $(\mathrm{NMHC}), \mathrm{NO}_{\mathrm{X}}$, and $\mathrm{CO}$.

\subsubsection{Sensors, Inc}

Sensors, Inc. developed an on-board system, the SEMTECH-D, for the measurement of diesel emissions [36]. SEMTACH-D uses NDUV, FID, and NDIR to measure the emissions constituents of $\mathrm{NO}, \mathrm{NO}_{2}, \mathrm{THC}, \mathrm{CO}$, and $\mathrm{CO}_{2}$. SEMTECH-D is capable of simultaneous measurement of vehicle tailpipe emissions and the output of the vehicles on-board electronic control system [49]. The system was recently deployed by the EPA to collect data from heavy duty vehicles in situ for a program involving air shed inventory modeling [49].

\subsubsection{Clean Air Technologies International}

Clean Air Technologies International has developed an on-board emissions testing system for light and heavy-duty vehicles with gasoline or diesel engines. The Montana System is capable of measuring second by second mass emissions from vehicles 
with electronically controlled sparked ignition (SI) and compression ignition (diesel) engines [43]. The unit utilized an NDIR for the measurement of $\mathrm{HC}, \mathrm{CO}, \mathrm{CO}_{2}$, and an electrochemical cell for the measurement of $\mathrm{NO}_{\mathrm{X}}$ and $\mathrm{O}_{2}$ for gasoline powered engines; for diesel powered engines, a light scattering is used to measure $\mathrm{NO}_{\mathrm{X}}, \mathrm{CO}, \mathrm{CO}_{2}, \mathrm{O}_{2}$, and PM [43].

There are different units designed for different vehicles. A universal unit measures emissions for both gasoline and diesel powered engines and gives $\mathrm{CO}, \mathrm{CO}_{2}, \mathrm{O}_{2}$, $\mathrm{NO}_{\mathrm{X}}, \mathrm{HC}$ readings for $\mathrm{SI}$ vehicles, and $\mathrm{NO}_{\mathrm{X}}, \mathrm{CO}, \mathrm{CO}_{2}, \mathrm{O}_{2}$, and $\mathrm{PM}$ for diesel vehicles [44]. The light-duty unit is capable of testing electronically controlled light-duty passenger vehicles and light trucks 1996 and newer. Second by second measurements of $\mathrm{CO}, \mathrm{CO}_{2}, \mathrm{NO}_{\mathrm{X}}, \mathrm{O}_{2}$, and $\mathrm{HC}$ are recorded for the gasoline vehicles [42]. The heavy-duty unit is capable of testing electronically controlled heavy-duty diesel vehicles for $\mathrm{CO}$, $\mathrm{CO}_{2}, \mathrm{O}_{2}, \mathrm{NO}_{\mathrm{X}}$, and PM measurements [40]. Also, there is an option to customize a unit for specific purposes not meeting the capabilities of the other units.

\subsubsection{Analytical Engineering Inc.}

An on-board measurement system, named SPOT, was integrated by AEI for the EPA [12]. The objective of this study was to measure instantaneous brake-specific $\mathrm{NO}_{\mathrm{X}}$. It measured $\mathrm{NO}_{\mathrm{X}}$ and $\mathrm{O}_{2}$ concentrations, as well as engine speed, exhaust mass flow rate, exhaust temperature, ambient temperature, barometric pressure, altitude, and vehicle velocity and position. The $\mathrm{NO}_{\mathrm{X}}$ was calculated on a gram per brake-horsepower hour basis and fuel-specific basis. 


\subsubsection{U.S. EPA}

The U.S. EPA is investigating approaches for qualifying predictive emissions modeling systems (PEMS) as alternatives to continuous emissions monitoring systems (CEMS) for determining $\mathrm{NO}_{\mathrm{X}}$ emissions from classes of combustion turbines [45]. The PEMS system incorporates a $\mathrm{ZrO}_{2}$ sensor for $\mathrm{NO}_{\mathrm{X}}$ measurement, a pressure drop device for flow measurement, and a data acquisition system that is used to record various information, such as: vehicle speed, engine speed, etc. To streamline the process for evaluating PEMS, EPA is investigating procedures for qualifying PEMS on classes of turbines, thereby simplifying the approval process for installation of PEMS on individual turbine units [45]. To collect the data necessary for this evaluation, EPA is planning to conduct field tests at several types of turbines. During the tests, $\mathrm{NO}_{\mathrm{X}}$ emissions predicted by various PEMS will be compared with continuous emissions monitoring systems (CEMS) data for accuracy, precision, ability to detect changes in emissions, and ability to meet the regulatory requirements of Subpart E of Part 75 of the Code of Federal Regulations (CFR) [45].

\subsection{MEMS Applications}

\subsubsection{MEMS Brake Specific $\mathrm{NO}_{X}$ Emissions Measurement}

With WVU's development of the MEMS on-board emissions measurement system, extensive investigation went into finding the best emissions sensors for their

applications. A zirconium oxide $\mathrm{NO}_{\mathrm{X}}$ sensor was found to be the most suitable available device for use in an on-road emissions measurement system [16]. Testing was conducted using the Mexa-120 Sensor and comparing it with a laboratory grade chemiluminescent 
analyzer (Rosemount Model 955), an NDIR NO analyzer with Luft detection (Horiba BE-220 NO micro bench), and an electrochemical NO cell. Using the MEXA-120 with the MEMS system, brake specific $\mathrm{NO}_{\mathrm{X}}$ were reported within $5 \%$ of the laboratory grade instruments.

\subsubsection{CARB Off-road Project}

The California Air Resources Board (CARB) has a project with WVU to measure and quantify the emissions output of off-road vehicles. These off-road vehicles include vehicles such as: bull dozers, excavators, street sweepers, tractors, etc. The testing included in the CARB Off- Road Report includes: on-board testing, field data collection of $\mathrm{CO}_{2}$ and speed, and emissions testing in an emissions test cell.

\subsubsection{In-field $\mathrm{CO}_{2}$ Emission Data}

A Sensors AMB-II multigas analyzer bench and associated data acquisition components were used to record $\mathrm{CO}_{2}$ data on-board an Elgin Pelican street sweeper (John Deere Engine), John Deere 444 rubber-tired front end loader (John Deere Engine), and a Komatsu PC400LC3 Excavator (John Deere Engine). One of the goals of the in-field testing was to accurately measure $\mathrm{CO}_{2}$ emissions during each vehicle's routine operation [15].

Operating the vehicles as they were intended and collecting the $\mathrm{CO}_{2}$ data allowed for real-world $\mathrm{CO}_{2}$ emissions results. The Elgin Pelican was operated through a route in Morgantown, WV and data was recorded. The John Deere front end loader was operated through two operations, a transport mode to the landfill site on hilly terrain and a scoop loading/unloading mode that was repeated numerous times during data collection. The 
Kumatsu Excavator was operated through three tests. The first test was a stationary digging operation in which the first half of the test was digging and the second half of the test was spent back-filling, and the second test simulated hauling or tramming (a tramming/hauling operation is when the excavator is moved in order to transport dirt from one location to another that is not within the reach of the boom). For the third test a trench was dug and then filled. This is probably the most common industrial use of the excavator.

The engines were pulled from these vehicles and tested in WVU's EERL. Test cycles were developed to recreate the $\mathrm{CO}_{2}$ emissions found in the field. The resulting emissions $\left(\mathrm{NO}_{\mathrm{X}}, \mathrm{PM}, \mathrm{HC}, \mathrm{CO}\right)$ generated from the test were measured using laboratory grade instrument emissions testing. It was assumed that recreating the $\mathrm{CO}_{2}$ emissions would recreate all the other emissions components as well. WVU's EERL and MEMS were used to measure the exhaust emissions from the engines as they were tested.

\subsubsection{Track-Type Tractor In-field Results}

A Caterpillar D11R CD bull dozer was tested using the Sensors AMB-II multigas analyzer bench on site at the Buffalo Coal Company strip mine in Mt. Storm, WV. The engine could not be pulled from the vehicle and transported to WVU's EERL because its size was too great; therefore, the MEMS system was used to collect the emissions data [15].

The MEMS system, with a novel realtime particulate matter system (Mari RPM100), was used to collect real-time, on-board emissions data from the dozer. The 
MEMS system measures $\mathrm{NO}_{\mathrm{X}}$ and $\mathrm{CO}_{2}$, thus $\mathrm{CO}$ and $\mathrm{HC}$ were not included in the dozer testing, and the Mari RPM100 measured real-time PM. This system (the MEMS and Mari RPM100) was mounted to the hood and top of the cab of the dozer, while the dozer was operated in its usual manner.

The emissions testing and cycle development work performed for the CARB OffRoad Study provides additional information needed for the development of testing protocols for diesel-powered off-road equipment. The data produced through this research could be used to promulgate and develop requirements and standards for the testing of diesel-powered off-road vehicles and equipment.

\subsubsection{Stationary Testing}

Several test cycles were run in WVU's EERL to compare the emissions data between MEMS and the laboratory instruments using the track-type tractor exhaust stack. Because the flow rates of the exhaust from the Series 60 engine are comparable to those through each exhaust stack on the track-type tractor, the tests were comparable. The engine was operated at steady-state set points for sufficient time to stabilize the pressure readings and using transient cycles, and the gaseous emissions concentrations measured with the MEMS. The calculated mass emissions rates were compared to those recorded by the full-flow dilution tunnel and laboratory emissions analyzers [15].

Emissions data were collected using the MEMS System, the RPM100, and the laboratory for the test cycle designed to mimic the operation of the track-type tractor. 
Coinciding with the validation of MEMS equipment was the adaptation of the MARI RPM100 for use as an on-board measurement system for off-road vehicles.

\subsubsection{Future Proposals}

WVU has proposed a test plan for the development of a test method to measure stationary and portable engine emissions for the California Air Resources Board. The proposal to develop a cost-effective in-the-field test method for these engines could be used as a screening tool to relate in-field emissions data with standards for newly manufactured off-road engines [17].

The proposed study is focused on developing a viable, cost-effective, easy-to-use and accurate in-field test method for stationary and portable engines that will yield in-use brake specific (or fuel specific) mass emissions data.

WVU has proposed a test matrix for the test method to measure stationary and portable engine emissions. It consists of laboratory testing, using the engine speed and loads specified in ISO 8178, 5-mode test. Emissions would be measured using California Exhaust Emissions Standards and Test Procedure. MEMS would also measure emissions from the tests. Engine specifications have been stated, and in-field testing engines have been contracted through WVU.

\subsection{V-Cone}

Rogalands Research, supported by the long term comparison data from Phillips Petroleum New Mexico, has shown that the V-Cone meter is superior in wet gas service than an orifice [12]. Southwest Research, Ohio University, and a Joint Industry project 
have also investigated the V-Cone with a wet gas [23]. Both of these studies have shown that the V-Cone has better performance to an Orifice Meter when measuring a wet gas.

McCrometer has also studied the permanent pressure losses of flow meters. Several flow meters where compared for permanent pressure losses for a 3" pipe with flows of $1145 \mathrm{lpm}$. The instruments include: Venturi (both a $7^{\circ}$ and $15^{\circ}$ exit angles), flow nozzle, vortex, turbine, Foxboro vortex, orifice plate, MicroMotion Coriolis, Foxboro Coriolis, and a V-Cone. Table 2.2 shows the ranking of the meters according to permanent pressure loss [22]:

Table 2.2 Flow meter rankings for permanent pressure loss.

\begin{tabular}{||l||l||l||}
\hline & Flow Meter & Pressure Loss $(\mathrm{kPa})$ \\
\hline \hline 1 & Venturi with $7^{\circ}$ exit angle & 4 \\
\hline \hline 2 & V-Cone & $\sim 3.5$ \\
\hline 3 & Venturi with $15^{\circ}$ exit angle & 4 \\
\hline \hline 4 & Flow Nozzle & 10 \\
\hline \hline 5 & Vortex & 14 \\
\hline \hline 6 & Turbine & 14.5 \\
\hline \hline 7 & Foxboro Vortex & 18.5 \\
\hline \hline 8 & Orifice Plate & 22 \\
\hline \hline 9 & MicroMotion Coriolis & 30 \\
\hline \hline
\end{tabular}




\begin{tabular}{|l||l||l||}
\hline \hline 10 & Foxboro Coriolis & 35 \\
\hline
\end{tabular}

Similar results were obtained when testing a 2" pipe with generally similar conditions, except that the Foxboro Coriolis and MicroMotion Coriolis switched places. The rest remained in the same order.

The V-Cone has been applied in several different industries with different measure gases. Several of theses applications are listed below [47]:

Table 2.3 Applications, and the Industry where applied, for the V-Cone.

\begin{tabular}{||l||l||}
\hline Industry & Application Gas \\
\hline \hline Analytical Instruments & Air flow measurement \\
\hline \hline Chemical Industry & Saturated Steam \\
\hline \hline Geothermal Power Industry & Geothermal Stream flow measurement \\
\hline \hline Metals \& Mining Industry & Exhaust flow measurement \\
\hline \hline Power Generation Industry & \\
\hline \hline
\end{tabular}

Field experiences with the V-Cone technology has reduced the skepticism, based on the radical change in emphasis of how the flow is measured, because of the large number of units in the field, greater than 40,000 [32]. There have been studies of orifice 
technology issues, including: beta edge degradation, stagnation area, and deposition. An orifice has a high cost of maintenance and intervention due to frequent plate changes [32]. Wet gas streams were also studied; Chevron researched, in field, the Cd movements outside the API requirements. They found that $2 \%-3 \% \mathrm{Cd}$ movements due to wet gas with liquid loads of only 0.33bbl/MMscf B2]. Wet gas streams were also studied in a laboratory environment. Using wafer cones, similar to V-Cone except removable, showed low susceptibility to $\mathrm{Cd}$ change with liquid load, base line values where plotted against numerous test loop instruments in a dry condition. Further work is underway to see the effect of low DP ranges on repeatability and accuracy and Y factor changes [32].

Field test applications can be seen from Table 2.3, where the industry and use of the V-Cone are listed.

McCrometer tested the V-Cone with the presence of a $90^{\circ}$ elbow and a double $90^{\circ}$ elbow, and compared it to an orifice plate. The V-Cone can be installed close - even close coupled - to either single or double elbows out of plane without affecting the stated accuracy of the meter more than $0.3 \%$ 24]. The orifice plate needed as much as fifty diameters of upstream pipe run depending on the beta ratio and the type of elbow upstream. The V-Cone showed that it is less susceptible to effects from elbows upstream than an orifice, effects up to $0.122 \%$ were shown 24]. The error is within the $2 \%$ allowed by the CFR. 


\subsection{FID Applications}

FID technology is standard in the measurement of the hydrocarbon component emissions in diesel engine exhaust; therefore, new research into FID's for that reason is limited. As mentioned previously, the University of California, Riverside, CE-CERT uses a FID for their hydrocarbon measurements [see Table 2.1]; and at the EERL at West Virginia University a FID, a Rosemount Analytical Model 402, is also used to measure hydrocarbons in their test cell. There are new applications for FID instruments. Some researchers are using FID's for the measurement of particulate matter in exhaust.

A dilution tunnel system, the most commonly used PM measurement technique, only measures total PM mass emissions during a testing period [29]. From their testing, Kawai et al. [29] were able to conclude that FID technology is able to not only measure hydrocarbon but also carbon PM. The acquired data using a practical engine shows a strong potential for the use of this technique in the development of the next generation of low PM emission diesel engines.

Imperial College of Science, Technology and Medicine, researchers used FID to empirically determine the fraction of hydrocarbons absorbed or condensed on particulates [2]. The researched found that using the FID offers advantages relative to other methods due to its simplicity and provides an alternative to the tedious, time-consuming dilution tunnel procedure which is not capable of characterizing transient particulate concentrations. Further research will concentrate on measuring rather than empirically determining the fraction of hydrocarbons on particulates. 


\section{Chapter 3 Experimental Setup}

\subsection{Introduction}

This chapter discusses the testing procedures and equipment used to during the experiment. The testing was conducted at West Virginia University's Engine and Emissions Research Laboratory (EERL). An overview of MEMS, and the development of MEMS, is included in this chapter, as well as an instrument that measures unburned hydrocarbons (Signal's Model 3030PM) and McCrometer's V-Cone flow meter. WVU's in-house engine emissions laboratory that is used at WVU's EERL is also discussed.

\subsection{Test Engines}

A Detroit Diesel Corporation (DDC) Series 60, 12.7 liter, 6 cylinder engine was tested at WVU's EERL. The Series 60 engine was on loan from the EPA for emissions testing. The DDC Series 60 is rated at $500 \mathrm{hp}, 1650 \mathrm{lb}$ - $\mathrm{ft}$ for the 12.7 liter, a 14.0 liter engine is available with a rating of $575 \mathrm{hp}, 1850 \mathrm{lb}-\mathrm{ft}$. The engine is designed so that the maximum torque is delivered at low horsepower, that is the horsepower curve provides $475 \mathrm{hp}$ or more all the way from 1500 to $2100 \mathrm{rpm}$. Below $1500 \mathrm{rpm}$, the maximum torque is $1650 \mathrm{lb}-\mathrm{ft}$, down to $1200 \mathrm{rpm}$ [51]. Figure 3.1 shows an engine in the test cell at WVU's EERL. 


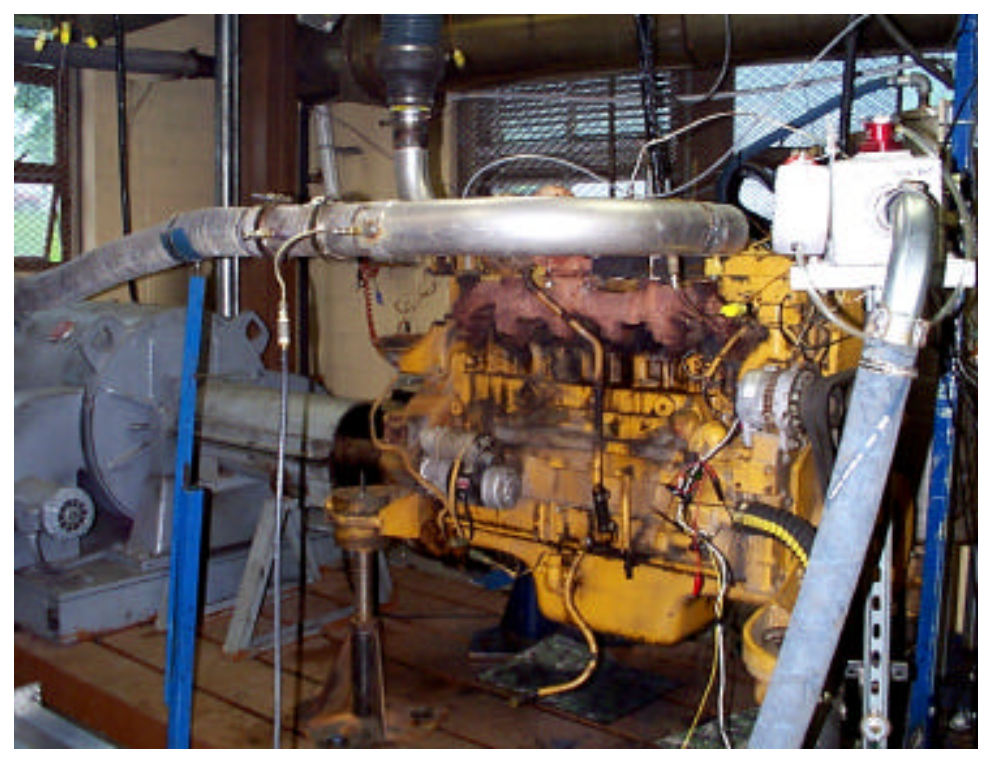

Figure 3.1 The WVU EERL test cell with an engine on the dynamometer, and the exhaust system. The Annubar ${ }^{\circledR}$ can be seen in the upper left hand corner.

A Volvo model VED123-425 was also tested in WVU's EERL test cell. The Volvo Model VE D12-425 is a 12.1 liter diesel engine. It is rated for $425 \mathrm{hp}$. The Volvo Model VE D12-425 is a heavy duty diesel engine used in Volvo Trucks for overland hauling.

\subsection{MEMS}

The following sections discuss the components of the first generation MEMS, instruments that are currently used in the system.

Previous research conducted at WVU designed, built and tested the equipment for the first generation MEMS in accordance to the design criteria that it measure the exhaust component accurately and precisely and be made robustly. 
The criterion for acceptance of the analyzers as a possibility for the first generation MEMS was accuracy and precision of the sensor, robustness of the sensor to handle on-board conditions, and the size of the sensor. Therefore, tests were conducted to quantify the analyzers response to the criteria of MEMS. All the first generation MEMS components were to fit into a 24 " by 24 " by 12 " enclosure. A gas bottle test was first conducted to qualify the analyzers accuracy. A sampling cart was built for initial engine testing, to see if temperature change, vibrations, inclination, etc. influenced the analyzers. The candidate analyzers that passed the gas bottle and stationary engine test were fitted into a 24 " by 24 " by 12 " box, and an on-board test was conducted. If one of the candidate analyzers did not meet the criteria for MEMS, it was eliminated from consideration. Figure 3.2 shows a picture of the first generation MEMS, and Figure 3.3 shows how MEMS system is integrated together for an engine emissions test.

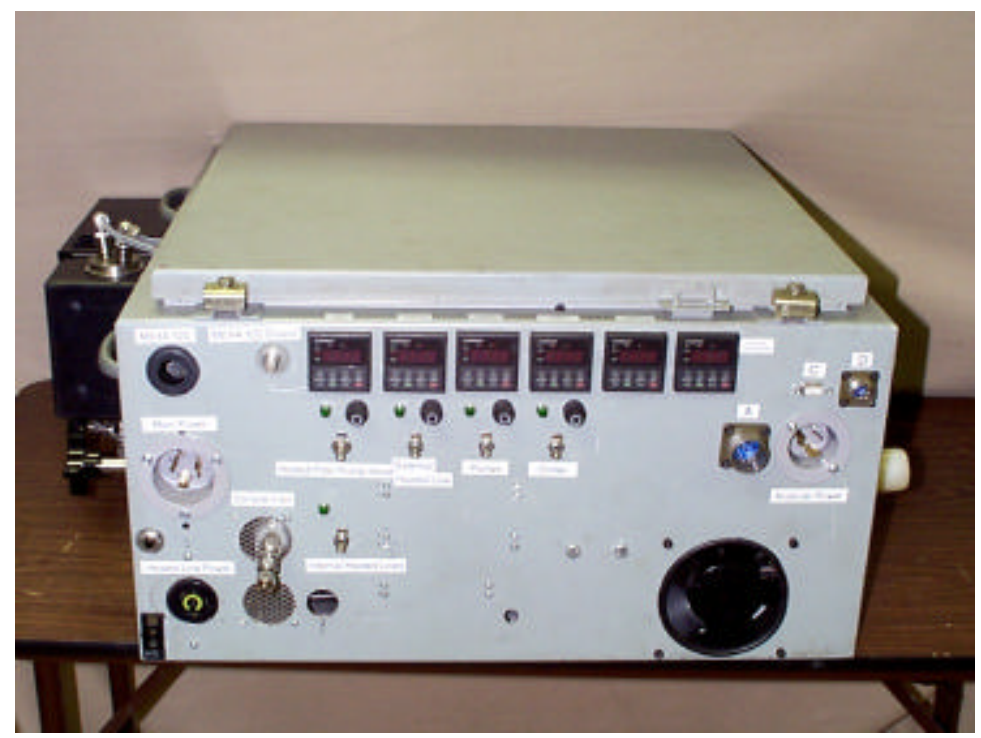

Figure 3.2 MEMS emissions box. 


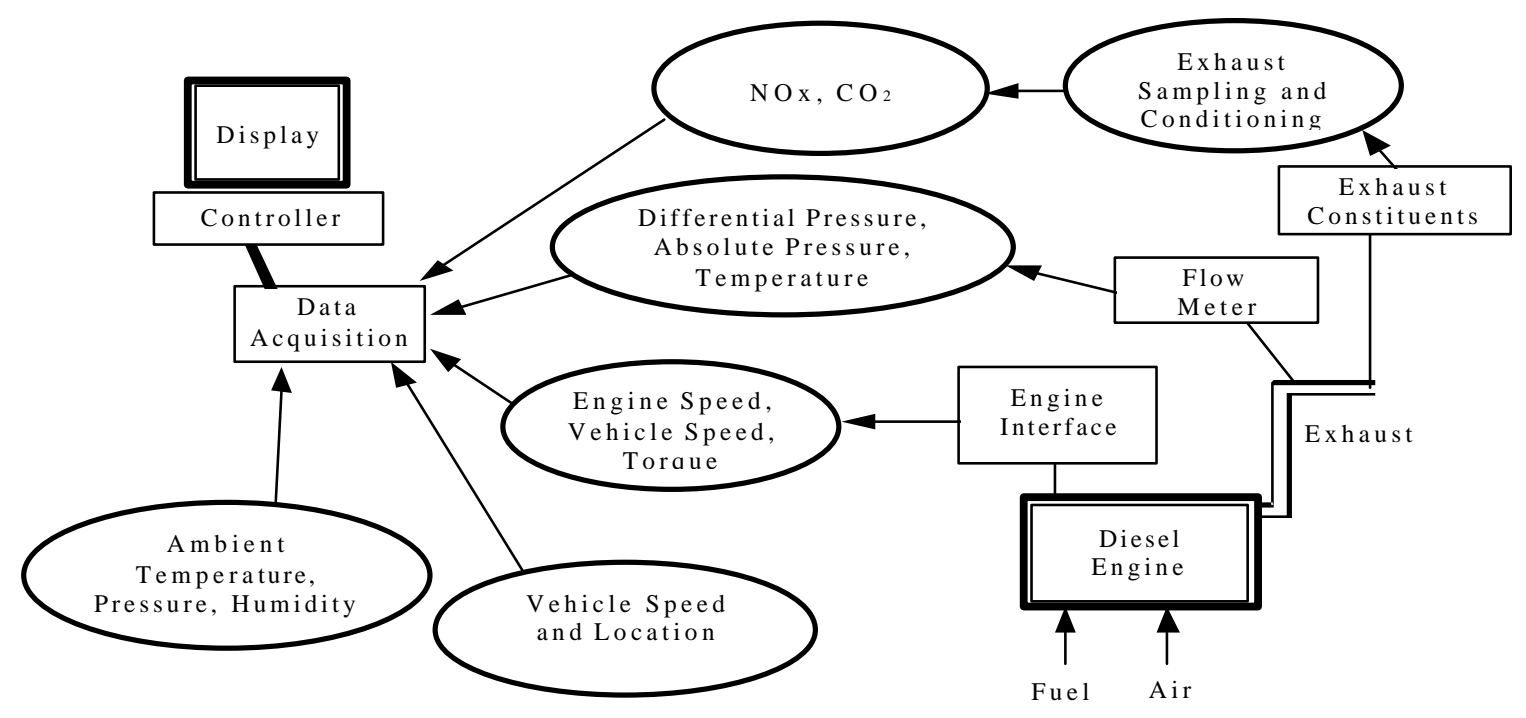

Figure 3.3 System integration of MEMS with the engine.

The second generation MEMS uses the same emissions sensors that were tested and used by the first generation MEMS. But, for the second generation MEMS, the chiller, for drying of the exhaust sample, and $\mathrm{NO}_{\mathrm{X}}$ converter were designed and fabricated in-house to reduce the size of the system.

\subsubsection{Flow Measurement}

The first and second generation MEMS uses an Annubar ${ }^{\circledR}$ to measure the total engine exhaust flow rate. The Annubar ${ }^{\circledR}$ is an averaging differential pressure-type flow measuring device. The Annubar ${ }^{\circledR}$ is shaped in a diamond with two chambers inside the diamond shaped tube, a high pressure chamber and a low pressure chamber. These chambers are isolated from each other. The diamond shape of the Annubar ${ }^{\circledR}$ separates the flow, reducing the permanent pressure loss due to the device. The differential pressure is averaged by having multiple pressure ports on both the high pressure and low pressure sides of the Annubar ${ }^{\circledR}$. Pressure transducers measure the differential pressures from each chamber and relay a signal to the data acquisition system. A Validyne P55D 
differential pressure transducer and an Omega PX 176 absolute pressure transducer is used to collect the pressure data for the flow measurement of the Annubar ${ }^{\circledR}$.

The high pressure is produced by impact or stagnation of the moving fluid on the Annubar $^{\circledR}$. Multiple sensing ports, located on the front of the sensor, sense the impact pressure profile. Inside the high pressure chamber on the front of the Annubar ${ }^{\circledR}$, the average pressure is generated. As the fluid continues around the sensor it generates a vortex shedding pattern and creates a low pressure profile. The low pressure is used as a pressure reference so that the velocity can be determined independent of pipe static pressure. The low pressure is sensed by ports, located downstream and opposite the high pressure ports. Inside the low pressure chamber, an average low pressure is generated to yield the differential pressure [48].

Most differential pressure-type flow meters require fully developed flow for accurate measurements. The Annubar ${ }^{\circledR}$ is no exception. For a five inch pipe, an approximately $6 \frac{1}{2}$ foot long segment is needed (ten diameters upstream and five diameters downstream). A shorter segment is needed for smaller diameter pipe, and longer segments are needed for larger diameter pipes. The Annubar ${ }^{\circledR}$ is inserted into the pipe at the midway point. The Annubar ${ }^{\circledR}$, because of the multi-port system, averages the pressures of the high and low velocity flows. Therefore, great concern is given in the orientation of the Annubar ${ }^{\circledR}$ in the pipe.

A picture of the exhaust system of the engine in the test cell is given in Figure 3.1.

\subsubsection{Gaseous Measurement}

In most laboratory experiments, the main emissions measurement components of a diesel engine are oxides of nitrogen $\left(\mathrm{NO}_{\mathrm{X}}\right)$, carbon dioxide $\left(\mathrm{CO}_{2}\right)$, and total particulate 
matter (PM). Other gases are also of concern, such as $\mathrm{CO}$ and total hydrocarbons. $\mathrm{CO}$ is found in low levels in diesel engine exhaust, and resolution and accuracy are a problem; therefore, because of the resolution and accuracy problems, the measurement of $\mathrm{CO}$ was not included in the gaseous measurements of MEMS. There are some hydrocarbon catalyst traps that produce $\mathrm{NO}_{2}$ by oxidizing soot with some NO to destroy the soot, and convert $\mathrm{CO}$ and $\mathrm{HC}$ into $\mathrm{CO}_{2}$ and $\mathrm{H}_{2} \mathrm{O}$. But during the regeneration (burning of the soot off the trap) of the catalyst trap some $\mathrm{CO}$ could be produced.

Hydrocarbon measurement will become an important with the 2004 regulations that require $\mathrm{NO}_{\mathrm{X}}+\mathrm{HC}$ measurements. In order to meet these regulations, the mobile emissions measurement systems need to measure HC accurately.

Some sensors use non-dispersive infrared (NDIR) to measure HC's, but the method was proved to lack accuracy when compared to a heated flame ionization detector (HFID). Most HFID analyzers are large and cumbersome, and therefore are not suited for on-board testing. HC was also neglected for the development of the first generation MEMS. The only diesel engine exhaust emission gases that MEMS measures is $\mathrm{NO}_{\mathrm{X}}$ and $\mathrm{CO}_{2}$.

The exhaust sampling system schematic, found in Figure 3.4, shows the progression of the exhaust through MEMS. 


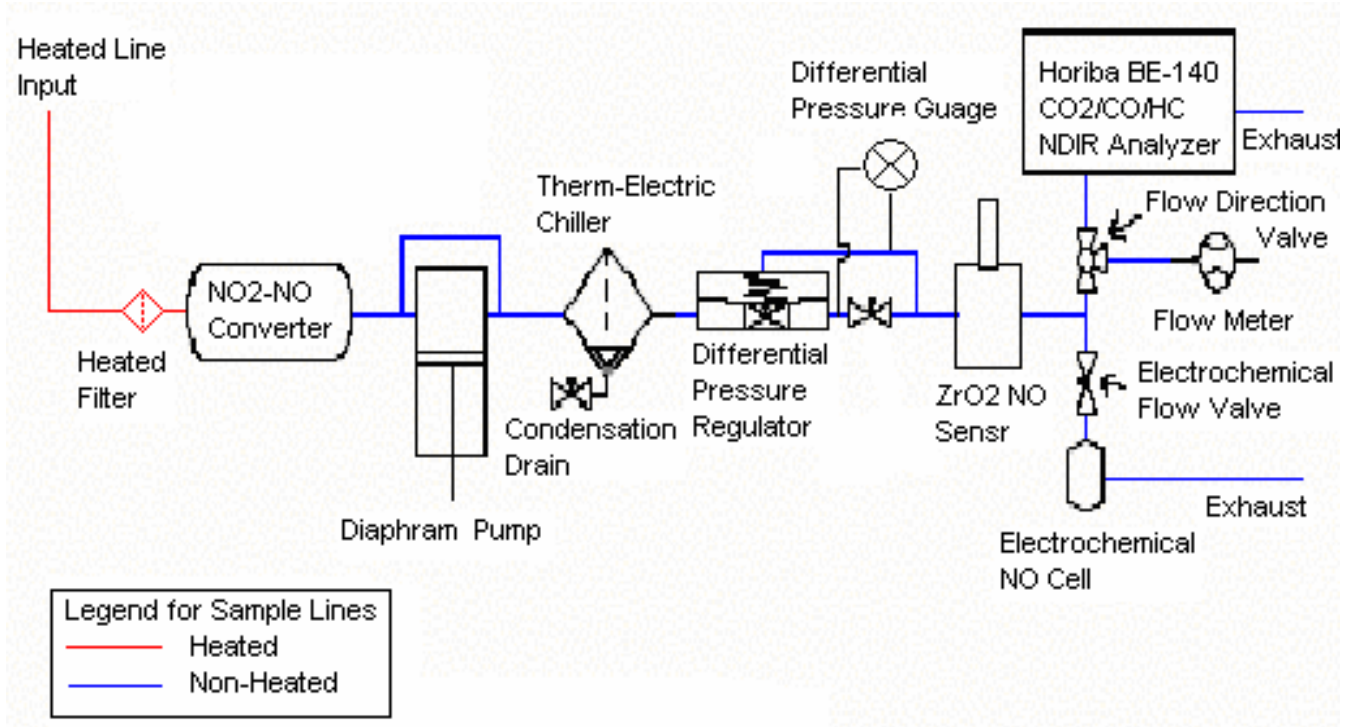

\section{Figure 3.4 Second generation MEMS exhaust sampling system.}

The exhaust sample is pulled from the exhaust stream into MEMS by using a diaphragm pump. Prior to the pump, a heated filter is used to eliminate the large particles and diesel soot from the sample, and then the sample passes through a $\mathrm{NO}_{\mathrm{X}}$ converter, which is also heated. Diesel engines produce a lot of $\mathrm{NO}_{2}$, thus to obtain an accurate measure of $\mathrm{NO}_{\mathrm{X}}$, the converter is needed to change $\mathrm{NO}_{2}$ to $\mathrm{NO}$. After the sample passes through the $\mathrm{NO}_{\mathrm{X}}$ converter, the sample is no longer heated. From the exhaust stream through the $\mathrm{NO}_{\mathrm{X}}$ converter, the sample is heated to $180^{\circ} \mathrm{C}$ to prevent condensation in the sample exhaust prior to the drying of the sample.

A chiller was designed in-house to lower the dew point and humidity of the sample. The chiller removes the moisture from the sample after the sample leaves the $\mathrm{NO}_{\mathrm{X}}$ converter and $\mathrm{ZrO}_{2}$ sensor, to ensure the emissions measurements are dry 
measurements. The chiller consists of a heat exchanger, Peltier elements, heat sinks, and fans. Downstream of the chiller, a differential pressure regulator is used to control the flow of the sample. A steady flow of 3 liters per minute is needed.

The sample is then introduced to the gas measurement analyzers. The analyzers in MEMS consist of Horiba BE-140 Multigas analyzer (for measurement of $\mathrm{CO}_{2}$ ), a Horiba MEXA-120 Zirconium-oxide $\left(\mathrm{ZrO}_{2}\right)$ analyzer (primary $\mathrm{NO}_{\mathrm{X}}$ analyzer), and an electrochemical NO cell (secondary $\mathrm{NO}_{\mathrm{X}}$ analyzer).

MEMS was designed with quality control features integrated into the emissions system. A secondary $\mathrm{NO}_{\mathrm{X}}$ analyzer located within MEMS is to ensure the primary $\mathrm{NO}_{\mathrm{X}}$ analyzer and $\mathrm{NO}_{\mathrm{X}}$ converter are working correctly. There is a likewise quality control system for $\mathrm{CO}_{2}$ that is relating $\mathrm{CO}_{2}$ from engine fueling rates.

\subsubsection{Gaseous Measurement Instruments}

\subsubsection{Horiba BE-140 Multigas (CO, $\left.\mathrm{CO}_{2}, \mathrm{HC}\right)$ Analyzer}

For the development of the first generation MEMS, analyzers that measured HC, $\mathrm{CO}$, and $\mathrm{CO}_{2}$ were tested, these include: Horiba BE-140, Andros 6800, Sensors Inc. AMBII, and Siemens SIBENCH. For MEMS the Horiba BE-140 was chosen as the sensor to measure the $\mathrm{CO}_{2}$ concentrations in the sample stream. The Andros 6800 and the Siemens SIBENCH did not work when tested and the Sensors Inc. AMB-II had a crippling data-time stamping problem, and was therefore eliminated.

The Horiba $\mathrm{BE}-140$ micro bench measures $\mathrm{CO}, \mathrm{CO}_{2}$, and $\mathrm{HC}$ concentrations. It is a NDIR based detector, with solid-state optical sensors [24]. The solid-state optical sensor makes large scale effects from vibration due to on-board testing unlikely. A single sample cell is used for the three gases. Infrared light energy is supplied directly through 
the sample cell onto the sensors at the opposite end of the cell. A constant speed chopper wheel rotates to allow the light source to reach only one of the four sensors at any time. A narrow band pass filter in front of each detector allows only energy of a wavelength corresponding to the gas of interest to reach that sensor. One of the four sensors is a reference sensor. The comparison of the outputs of the three detectors measuring gases with the reference detector generates the concentration of the gases. Each of the sensors is a dual element unit with only one element exposed to the light source. This provides for nullification of temperature effects.

The BE-140 was designed for gasoline engine automotive testing. The measurement ranges for each gas of interest is within typical concentration of raw exhaust gases from a diesel engines. However, the concentrations of $\mathrm{CO}$ and $\mathrm{HC}$ in the exhaust are so low that the resolution and/or accuracy would be poor. The BE-140 can be spanned to measure gas concentrations accurately in the following ranges: $3-20 \%$ $\mathrm{CO}_{2}, 1.2-10 \% \mathrm{CO}$, and 1200-20000 ppm (propane).

\subsubsection{Horiba Mexa-120 NOX Analyzer}

Several of the analyzers tested for $\mathrm{CO}, \mathrm{CO}_{2}$, and $\mathrm{HC}$ measurement also measure $\mathrm{NO}$ and $\mathrm{NO}_{\mathrm{X}}$ by some scheme. The Andros 6800 multigas analyzer uses an electrochemical NO cell to determine the NO is the sample stream. The Siemens SIBENCH uses an NDIR detector to measure NO in the same manner that it measures $\mathrm{CO}, \mathrm{CO}_{2}$, and $\mathrm{HC}$. The Sensors AMB-II also uses an electrochemical NO cell to measure NO. Other $\mathrm{NO}_{\mathrm{X}}$ analyzers that were tested for MEMS are the Horiba MEXA-120, the Horiba BE-220, and a Siemens Inc. Electrochemical NO Cell. MEMS uses the Horiba 
MEXA-120 as the primary $\mathrm{NO}_{\mathrm{X}}$ analyzer and the electrochemical $\mathrm{NO}$ cell as a secondary measurement.

The Horiba MEXA-120 zirconium oxide analyzer is capable of measuring $\mathrm{NO}_{\mathrm{X}}$ in concentration up to 5000ppm. The MEXA-120 is a derivative of an NGK sensor, and it is designed to be placed directly in the exhaust flow

The Horiba MEXA-120 Zirconium-oxide sensor is made of ceramic material, zirconium-oxide $\left(\mathrm{ZrO}_{2}\right)$. The platinum coated zirconium oxide, when heated to $700^{\circ} \mathrm{C}$ will allow oxygen to readily pass through the material as $\mathrm{O}_{2}^{-}$ions. The oxygen will migrate toward the side of the zirconium oxide exposed to the lowest concentration of oxygen, unless it is subjected to an electric current, which will cause a flow of oxygen from a higher to lower concentration [26]. 


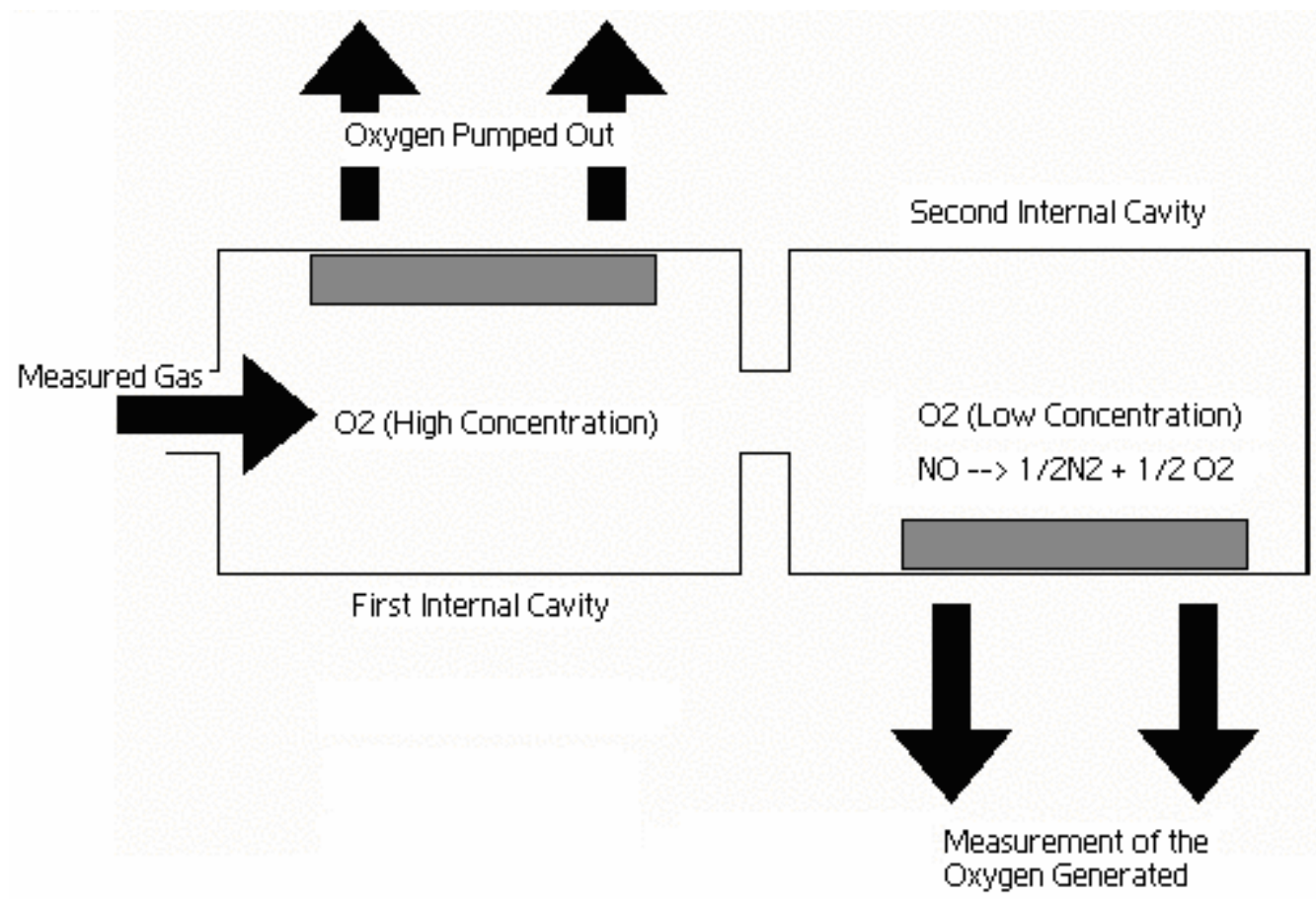

Figure 3.5 Principal of zirconia $\mathrm{NO}_{\mathbf{X}}$ sensor.

The MEXA-120 consists of two internal chambers. The first chamber receives the sample gas through the first diffusion path. In the first chamber, the oxygen present in the sample is pumped out, by supplying current to the section of the chamber wall that is zirconium oxide. Therefore the concentration of oxygen is low within the chamber. The sample stream then fills the second internal chamber, where the oxygen concentration is lower than the first chamber. The sample is then dissociated into nitrogen and oxygen. The sensor is heated to approximately $700^{\circ} \mathrm{C}$ to allow for the oxygen ions to migrate through the zirconium-oxide material. The oxygen generated from the dissociation is then pumped out by supplying a constant voltage across the second section of zirconium oxide within the second chamber. $\mathrm{NO}_{\mathrm{X}}$ concentration is measured by determining the amount of current necessary to pump the $\mathrm{O}_{2}$ out of the second chamber. 
It should be noted that there is some limitations to the MEXA-120. It is reported by the manufacturer that the sensor is sensitive to ammonia $\left(\mathrm{NH}_{3}\right)$, oxygen $\left(\mathrm{O}_{2}\right)$, ozone $\left(\mathrm{O}_{3}\right)$, and $\mathrm{CO} . \mathrm{NH}_{3}$ is a small constituent in diesel exhaust and the $\mathrm{O}_{2}, \mathrm{O}_{3}$, and $\mathrm{CO}$ levels are low enough to assume negligible. The major concern for the MEXA-120 is moisture condensation in the sample stream. A large amount of moisture condensation could cause the ceramic material to cool rapidly and crack. But by continuing to heat the sample, and preventing condensation, MEMS avoids this problem.

\subsubsection{Sensors Inc. Electrochemical NO Cell}

Sensors, Inc. markets an electrochemical cell produced by City Technology of U.K. The electrochemical NO cell operates on the principle of gaseous diffusion barrier [35]. In one operation scheme of an electrochemical NO cell, two electrodes are used, a sensing electrode and a counter. A thin layer of electrolyte separates the two, and an external circuit connects them. 


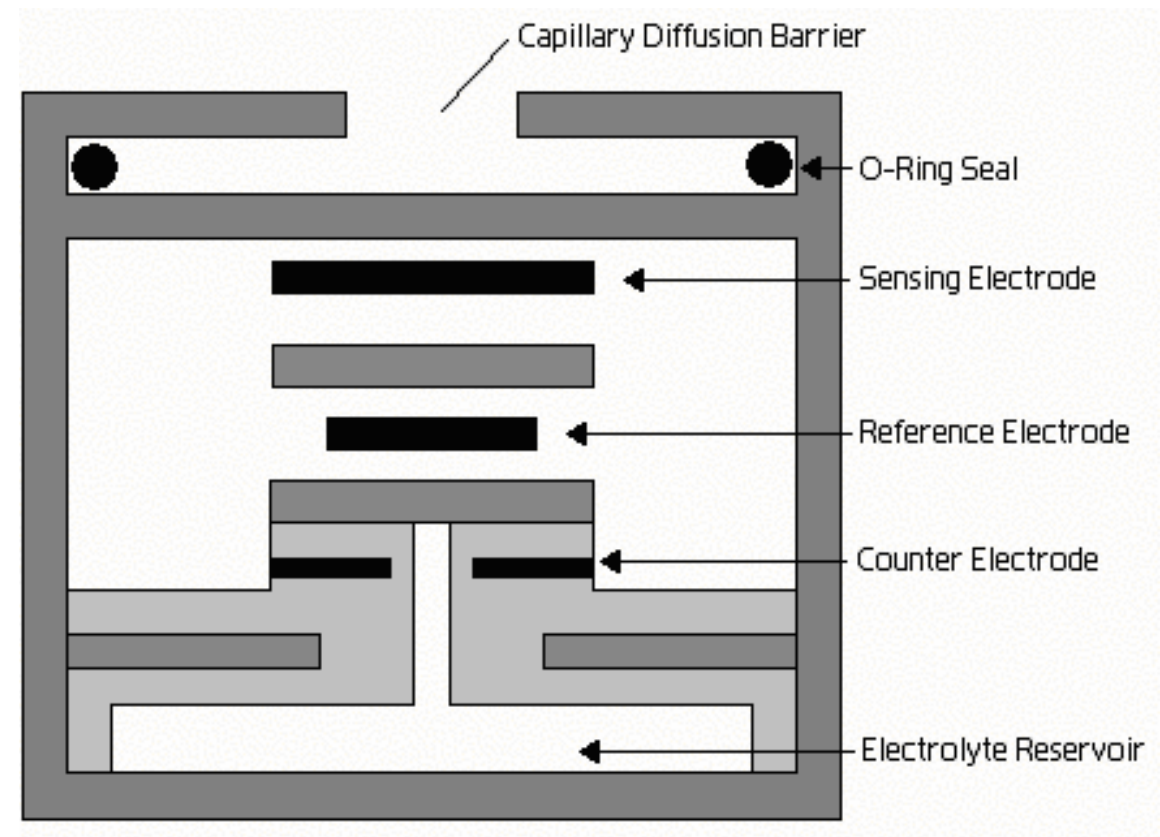

Figure 3.6 Electrochemical NO cell schematic.

The electrochemical NO cell reads only $\mathrm{NO}$, requiring a $\mathrm{NO}_{\mathrm{X}}$ converter upstream of the device. The electrochemical cell is very small, and has a low cost compared to other $\mathrm{NO}$ or $\mathrm{NO}_{\mathrm{X}}$ analyzers. The recommended operating range of relative humidity is between $15-90 \%$. Therefore the sample stream had to have at least $15 \%$ relative humidity to prevent the water from the electrolyte from diffusing into the stream. If the electrolyte volume decreases by $40 \%$ or more, the output signal will be affected.

Operating over $90 \%$ relative humidity will cause the electrolyte to absorb water out of the stream and cause possible leakage from the electrolyte.

In the MEMS the sample is pumped, downstream of the MEXA-120, into a small manifold containing a cell at a flow rate of about $0.5 \mathrm{lpm}$. The sample migrates through a membrane, where it reacts with the sensing electrode by either oxidation or reduction. This reaction causes a current to flow between the sensing and counting electrodes, which 
is proportional to the concentration of $\mathrm{NO}$ in the sample and can be measured in the external circuit.

\subsubsection{Thermoelectric Chiller: $M \& C$ Products Analysis Technology Inc. Model ECP1000}

For the first generation MEMS, a Model ECP1000 chiller was used to remove the water from the sample stream. It operates on the Peltier effect. The Peltier effect is observed when two different metal (or semiconductors) are connected in a loop, and current is run through the loop creating a small voltage across the junction of the two metals. The temperature will increase at one junction and decrease at the other. The sample gas flows through a heat sink located at the cooling junction of the loop. Heat is transferred to the sink from the gas, reducing the temperature of the sample gas. The cooling junction then transfers heat across the junction to the hot junction of the loop. A heat sink then absorbs heat from the hot junction. Heat is then transferred out of the sink by a fan blowing across fins to reduce the temperature of the sink, thus continuing the heat transfer from the sample gas. The heat transfer from the sample gas lowers the dew point temperature of the sample gas present in the chiller.

The in-house chiller, used for the second generation MEMS, consists of a heat exchanger, Peltier elements, heat sinks, and fans. This chiller is insulated using spray foam.

\subsubsection{Engine Speed and Torque}

Engine speed may be measured with a variable reluctance pickup or Hall Effect sensor that normally measures engine speed. A description of Hall Effect is a magnet that 
is placed on an element that operates in a cyclic manor; a sensor produces a voltage when the magnetic field from the magnet comes in contact with it. In the case of engine testing, to measure engine speed, a magnet is placed on the flywheel. A sensor produces a voltage when the magnet on the flywheel completes one revolution, thus yielding rpm. Many engines use one of these sensors to broadcast the engine speed via the ECM. For MEMS, the speed was easily read by the data acquisition system integrated with the ECM in broadcast mode.

There are a couple of different ways to measure torque. An estimation of torque can be acquired by using the ECM measurement of torque. But the ECU's calculated torque is estimated by engine fuel consumption, and this is not an accurate measure of torque. A more accurate measurement of toque would be through the level of $\mathrm{CO}_{2}$ in the exhaust and brake-specific fuel consumption. This yields an accurate torque measurement by eliminating many of the errors associated with engine parameters, but it also requires knowledge of fuel properties, such as hydrogen-to-carbon ratio and energy densities. For MEMS, torque is recorded from the ECU.

\subsubsection{Data Acquisition}

The data acquisition of MEMS consists of a computer, data acquisition and conditioning hardware, and software for control and data acquisition. MEMS was designed for on-road testing, with robustness and size as factors; the data acquisition was designed in the same manner. Therefore it was designed to be rugged and sturdy. The data acquisition operates off of 110 volt AC or $12 \mathrm{~V}$ supply. To provide the $110 \mathrm{~V} \mathrm{AC}$ 
necessary, a generator is used, although the goal is that the power consumption will be reduced so that a power converter can be used to power MEMS.

The data acquisition receives signals from the MEMS instruments and the vehicles computer. It receives both analog and digital signals. The system must be able to read signal from thermocouples, pressure transducers, emissions analyzers, speed sensors, and numerous ECM signal.

For the first generation MEMS, the data acquisition used different components. National Instruments Corp. produces a computer, a PXI-1025, that has been determined to be the best fit for on-road, in-use testing. The PXI-1025 is used for the first generation MEMS computer. Windows NT is used as the operating system because of its memory and networking capabilities, software and support. The data acquisition hardware is dependant upon the computer choice and sensor requirements. Interface components include ISA bus plug-in cards, PCI bus plug-in cards, universal serial bus (USB) devices, PCMCIA cards, and parallel printer port devices.

For the second generation MEMS data acquisition components consist of National DAQcard-6024E (the data acquisition board), National Instruments SC-2345 Signal conditioning box, and an Adventech PCM-9570S for the main board. The computer has an $800 \mathrm{MHz}$ processor; memory consisted of two $128 \mathrm{MB}$ of RAM, $30 \mathrm{~GB}$ of hard drive memory, and a Viewsonic 15" VG150 flat screen monitor. Also, a Dearborn Electronics DG DPAIII/PC104 module was used for communication with the ECU of the test vehicle.

The MEMS data acquisition software includes a WVU developed program that allows the user to control the number of devices to be monitored, to calibrate 
components, and to alter the data recording frequency, as some sensors require faster or slower interaction.

\subsection{Signal Model 3030PM Hydrocarbon Analyzer}

The Signal Model 3030PM is a heated flame ionization detection hydrocarbon analyzer. It is designed to measure organic vapors in combustion stack gases and high dew point samples. Internal pumps provide the vacuum between 5.5 and 7.5 psi to draw the sample through the heated line. A flame ionization detector with a cylindrical collector, flame detector, and igniter are housed in the temperature controlled oven, kept at $675^{\circ} \mathrm{C}$. A heated sample line is used to transport the exhaust sample to the analyzer. An electrical signal is produced proportional to the number of carbon atoms present in the sample. The signal is amplified and digitized for maximum accuracy [1]. A full function microprocessor provides for both digital and analog inputs. For the testing, the analog signal output from Model 3030PM was integrated with the data acquisition system of the EERL. The analog signal was inputted into the secondary hydrocarbon channel in the EERL data acquisition. Figure 3.7 shows a picture of the Signal Model 3030PM. 


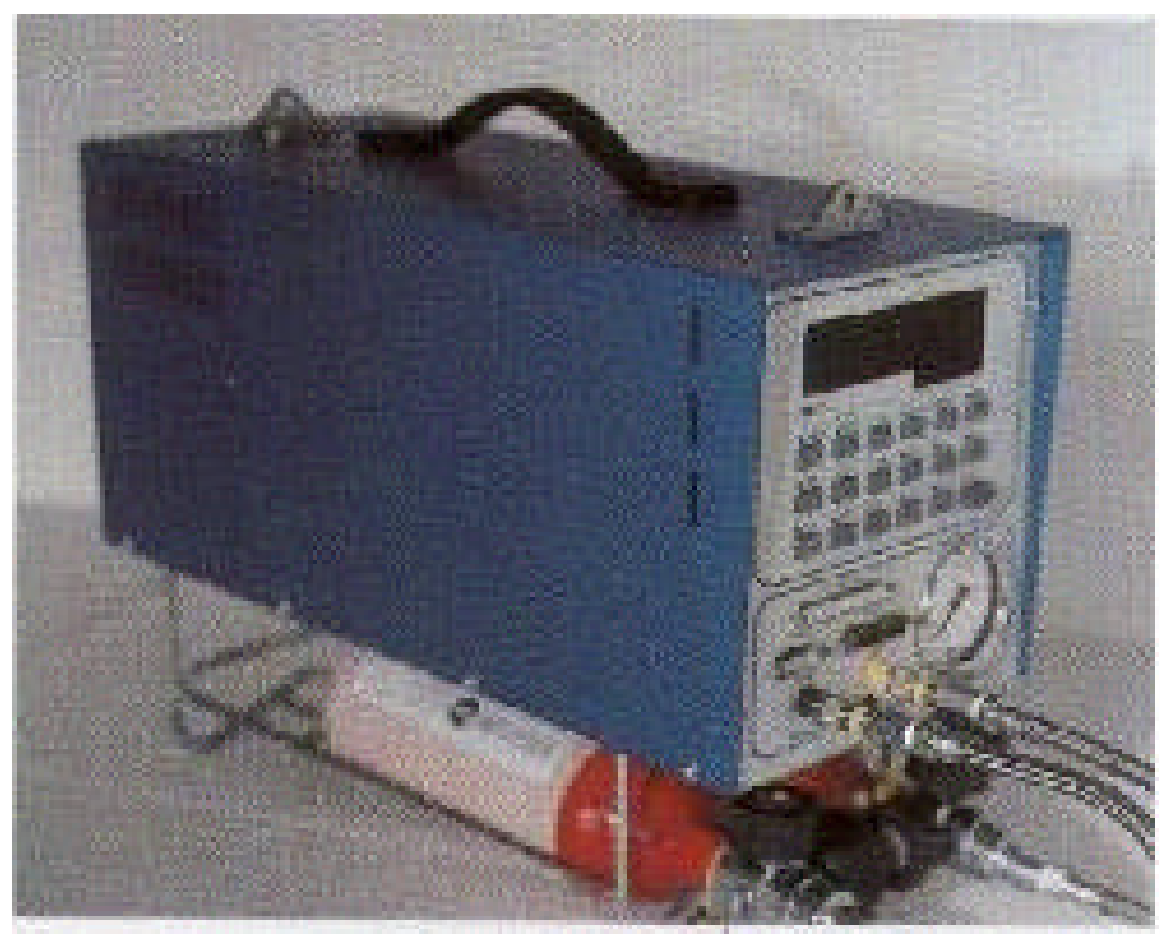

\section{Figure 3.7 Signal Model 3030PM portable hydrocarbon analyzer.}

The flame ionization detector works by passing the sample through an ionizing hydrogen flame. The carbon atoms become charged. The ions are then collected onto a polarized electrode outside the combustion zone. The resultant electrical current is proportional to the mass of carbon present in the flame. This electrical current is small and needs to be amplified to produce the signal. The flame fuel is a $40 \%$ hydrogen, $60 \%$ helium mixture.

The analyzer needs a reference point in order to quantify the concentration of hydrocarbon in the sample. Therefore, a hydrocarbon free sample is provided as the reference. The built-in internal catalyst removes hydrocarbons from ambient air to meet this need. The ambient air is passed over a platinum coated catalyst on an alumina 
substrate at a high temperature. Zero air is also needed to give a stable signal. The hydrocarbon free air produced by the catalytic process meets this need as well.

There are several features of note for the Signal Model 3030PM. The Model 3030PM has an automatic calibration feature. Signal 3030PM analyzer specifications include 1.5 seconds for $95 \%$ response, less than $2 \%$ drift in 8 hours, 0.03 ppm propane detector noise, manifold temperature stable at $200^{\circ} \mathrm{C}$ [49].

Span gas is provided to the analyzer from a port in the front of the analyzer, and the analyzer generates its own zero air. Zero, span, or both can be re-calculated at any time using the button on the front panel. An automatic calibration can be set, so that zero and span will be re-calculated at a specific time increment. There is also manual zero and span adjustments on the back panel of the analyzer.

The concentration range can be set to values of $0-4,0-10,0-40,0-100,0-400,0-$ $1000,0-4000$, and $0-10000 \mathrm{ppm}$ ranges. The analog output is from 0-10V. When a specific range is selected, the analyzer automatically sets the low range as $0 \mathrm{~V}$, and the high range as $10 \mathrm{~V}$. The span gas value must be inputted into the analyzer by setting the span. The value entered must be in methane equivalent form. This is important for the calibration of the analyzer. If the analyzer reads a value for the span gas significantly different from the value that span was set to, it will give an error and the calibration will be aborted. There are also procedures to reset the oven temperature, catalyst temperature, and several other parameters that are not crucial to the operation of the analyzer.

One apparent drawback of the Signal Model 3030PM that is noticeable is that there are lot of features (remote control capabilities, integration capabilities with a RS- 
232 ports, etc) that are not needed for automotive applications. They are added features that add bulk and unnecessary complexity.

For on-board applications, power consumption is an important issue. The Signal Model 3030PM is interchangeable between 115VAC and 230VAC +/- 15\%, $50 \mathrm{~Hz}$ or 60 $\mathrm{Hz}$ [1]. The maximum power consumption is $40 \mathrm{~W}$. Included in the power specifications are the requirements for the heated line. MEMS currently uses heated lines; therefore, for the integration with MEMS, the heated line power consumptions specifications will not be addressed.

\subsection{V-Cone ${ }^{\circledR}$}

The MEMS system pulls a small sample of exhaust compared to the total exhaust exiting the engine. Because the emissions test is conducted on a small sample, there must be a way to relate the emissions data to the engine. Therefore, a total flow rate measurement must be made to accurately obtain the accurate emissions data for the engine.

The McCrometer V-Cone ${ }^{\circledR}$ is a differential pressure-type flow meter. It operates on the same principle as most differential pressure-type flow meters, using the same theorem of conservation of energy in fluid flow through a pipe [40]. Most differential pressure-type flow meters measure accurately only when the flow is fully developed. To ensure that the flow is fully developed, the flow should have an unobstructed and straight pipe for ten diameter (of the pipe) upstream and five diameters downstream of the differential pressure device. In the case of MEMS, if a 5-inch exhaust pipe is used, a pipe of 100 inches must be used with the differential pressure ports midway. 
The V-Cone ${ }^{\circledR}$ is its own flow conditioner, fully conditioning the flow. The VCone overcomes the problem of trying to measure disturbed flow by reshaping and distributing the upstream velocity profile [32]. The result of mixing the flow is a low amplitude high frequency signal with little bounce in the signal. A static pressure port is located just upstream of the mass, and a second low pressure port is located on the back side of the conical mass as seen in Figure 3.8 give the differential pressure readings. An Omega model PX 176 025A absolute pressure transducer was used to record absolute pressures. A $0-5 \mathrm{~V}$ signal output corresponds to absolute pressure measurements up to 25 psia. A Viatran model 2746CED differential pressure transducer was also used. It measures differential pressures up to 20 inches of water column.

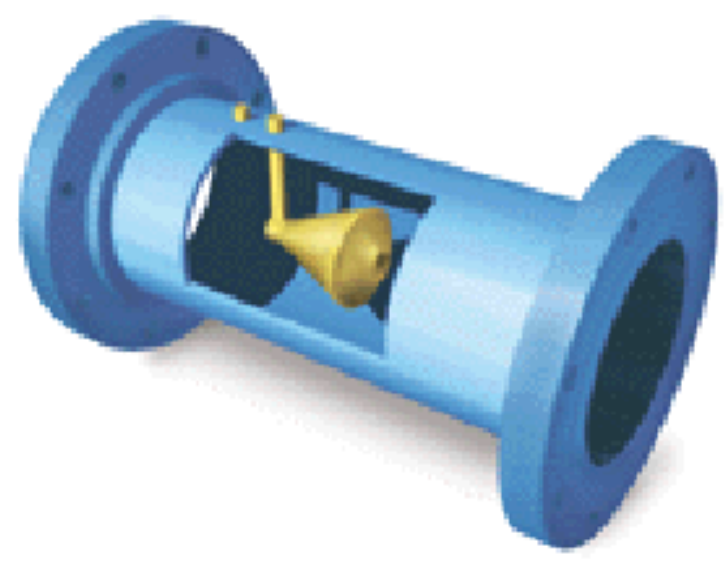

Figure 3.8 A cutout of the V-Cone showing the conical mass in the center of the flow, and the pressure ports.

Because the conical mass forces the flow around the cone, mixing the high and low velocity flows; it fully conditions the flow and the need for diameters upstream and downstream is eliminated. Eliminating the need for fully developed flow results in the 
elimination of any unobstructed, straight pipe flows upstream or downstream, significantly reducing the length of the pipe. The V-Cone can even be placed directly downstream of an elbow or something disrupting the flow, and it will measure accurately [40].

A characteristic of engine exhaust flow is that there are pulsations within the exhaust flow. The multiple stroke characteristics of the engine cause the exhaust to have pulsations, not a constant, steady flow. The V-Cone ${ }^{\circledR}$ fully conditions even pulsating flows. Another problem with diesel engines is PM buildup on a pressure sensing device. PM buildup on a V-Cone ${ }^{\circledR}$ should not affect the accuracy because the low pressure port is located on the rear of the cone. The PM buildup will not clog the port.

The manufacturer claims the $\mathrm{V}$-Cone ${ }^{\circledR}$ is accurate to $\pm 0.5 \%$ for difficult flows and under a wide variety of Reynolds numbers and repeatability of $\pm 0.1 \%$ or better. Standard Beta ratios are available, while the V-Cone ${ }^{\circledR}$ tested for this report is 0.8 beta ratio. Another advantage to the $\mathrm{V}-\mathrm{Cone}{ }^{\circledR}$ is permanent head loss is low. The manufacturer calibrated the V-Cone ${ }^{\circledR}$, and the sizing sheet claimed a permanent head loss of less than 5 inches of water column, although the head loss changes under different flow conditions.

The differential pressure transducer for the V-Cone ${ }^{\circledR}$ is needed that can handle differential pressure readings as low as 0.2 inches of $\mathrm{H}_{2} \mathrm{O}$ and as large as 15 inches of $\mathrm{H}_{2} \mathrm{O}$. The differential pressure transducer needs to be compatible with exhaust. Exhaust can contain moisture, thus the transducer must be able to operate when moisture is in the fluid. An absolute pressure transducer is needed to measure the absolute pressure and the temperature of the V-Cone ${ }^{\circledR}$ is also needed. The equations below calculate the standard 
flow rate of the exhaust based on the pressures and temperature readings obtained and base values for the pressures and temperature. (Nomenclature is located in Table 3.1 below).

The actual cubic feet per second is obtained from either Equation 1 or Equation 2.

\section{Equation 1}

$A C F S=k_{1} * Y \sqrt{\frac{5.197 * \Delta P}{\rho}}$

or

\section{Equation 2}

$$
A C F S=F_{a} *\left(K_{T 1}-K_{T 2}\left(\frac{\Delta P}{P}\right)\right) \sqrt{\frac{\Delta P^{*} T}{P}}
$$

where $\mathrm{k} 1$ can be obtained from the sizing report for the V-Cone using McCrometer's software.

\section{Equation 3}

$$
k_{1}=\frac{\pi}{576} \sqrt{2 * G_{C}} \frac{D^{2} \beta^{2}}{\sqrt{\left(1-\beta^{4}\right)}} C_{F}
$$

The expansion factor $\mathrm{Y}$ is based the differential pressure, absolute pressure, beta ratio, and the isentropic exponent $\mathrm{k}$.

\section{Equation 4}

$$
Y=1-\left(0.649+0.696 * \beta^{4}\right) * \frac{\Delta P}{k * P}
$$

The gas density is calculated using Equation 5.

\section{Equation 5}

$$
\rho=2.6988 \frac{S_{S T P} * P}{Z * T}
$$


The standard cubic feet per minute is calculated by Equation 6 .

\section{Equation 6}

$$
S C F M=A C F S *\left(\frac{P * T_{b} * Z_{b}}{P_{b} * T * Z}\right) * 60
$$

Table 3.1 Nomenclature of the V-Cone flow rate calculation.

\begin{tabular}{|c|c|c|c|}
\hline Variable & & Variable & \\
\hline $\mathrm{G}_{\mathrm{C}}$ & Gravitation Constant $(=32.2)$ & $\mathrm{k}$ & Isentropic exponent \\
\hline $\mathrm{D}$ & $\begin{array}{l}\text { Outside Diameter of the V- } \\
\text { Cone }{ }^{\circledR}(=5 ")\end{array}$ & $\mathrm{Y}$ & Gas Compressibility Factor \\
\hline B & Beta Ratio $(=0.8)$ & $? \mathrm{P}$ & Differential Pressure \\
\hline $\mathrm{C}_{\mathrm{F}}$ & Flow Meter Coefficient $(=0.78)$ & $?$ & Density of the Gas \\
\hline$P$ & Operating Pressure & $\mathrm{S}_{\mathrm{STP}}$ & $\begin{array}{c}\text { Specific Gravity at Standard } \\
\text { Conditions }\end{array}$ \\
\hline $\mathrm{P}_{\mathrm{b}}$ & Base Pressure & ACFS & Actual Cubic Feet per Second \\
\hline $\mathrm{T}$ & Operating Temperature & SCFM & Standard Cubic Feet per Minute \\
\hline $\mathrm{T}_{\mathrm{b}}$ & Base Temperature & $\mathrm{K}_{\mathrm{T} 1}$ & $\begin{array}{l}\text { Meter flow Constant \#1 } \\
\qquad(=0.9736)\end{array}$ \\
\hline $\mathrm{Z}$ & Gas Compressibility & $\mathrm{K}_{\mathrm{T} 2}$ & $\begin{array}{c}\text { Meter Flow Constant \#2 } \\
(=0.0239)\end{array}$ \\
\hline $\mathrm{Z}_{\mathrm{b}}$ & Base Gas Compressibility & $\mathrm{F}_{\mathrm{a}}$ & $\begin{array}{l}\text { Correction Factor for Thermal } \\
\quad \text { Expansion } \\
\text { (unit less; approx. }=1.014-1.02 \text { ) }\end{array}$ \\
\hline
\end{tabular}




\begin{tabular}{||l||l||l||l||}
\hline $\mathrm{k}_{1}$ & Flow Constant & & \\
\hline
\end{tabular}

The most glaring problem with the V-Cone ${ }^{\circledR}$, in its current configuration, is that it is made out of schedule- 40 stainless steel pipe. The V-Cone ${ }^{\circledR}$ weights approximately 40 lbs. For on-road testing, the flow rate meter is mounted directly to the exhaust stack of the vehicle. And with the weight of the V-Cone ${ }^{\circledR}$, stability would be difficult to obtain without utilizing extra support for the V-Cone on the exhaust stack.

\subsection{West Virginia University's Engine and Emissions Research Laboratory}

All testing covered in this report was conducted at West Virginia University's Engine and Emissions Research Laboratory (EERL). The EERL was built according to the specifications outlined in CFR 40, Part 86 Subpart N [9]. An overview of the components of the EERL is given in this section. Figure 3.9 shows a schematic of WVU's EERL test cell. 


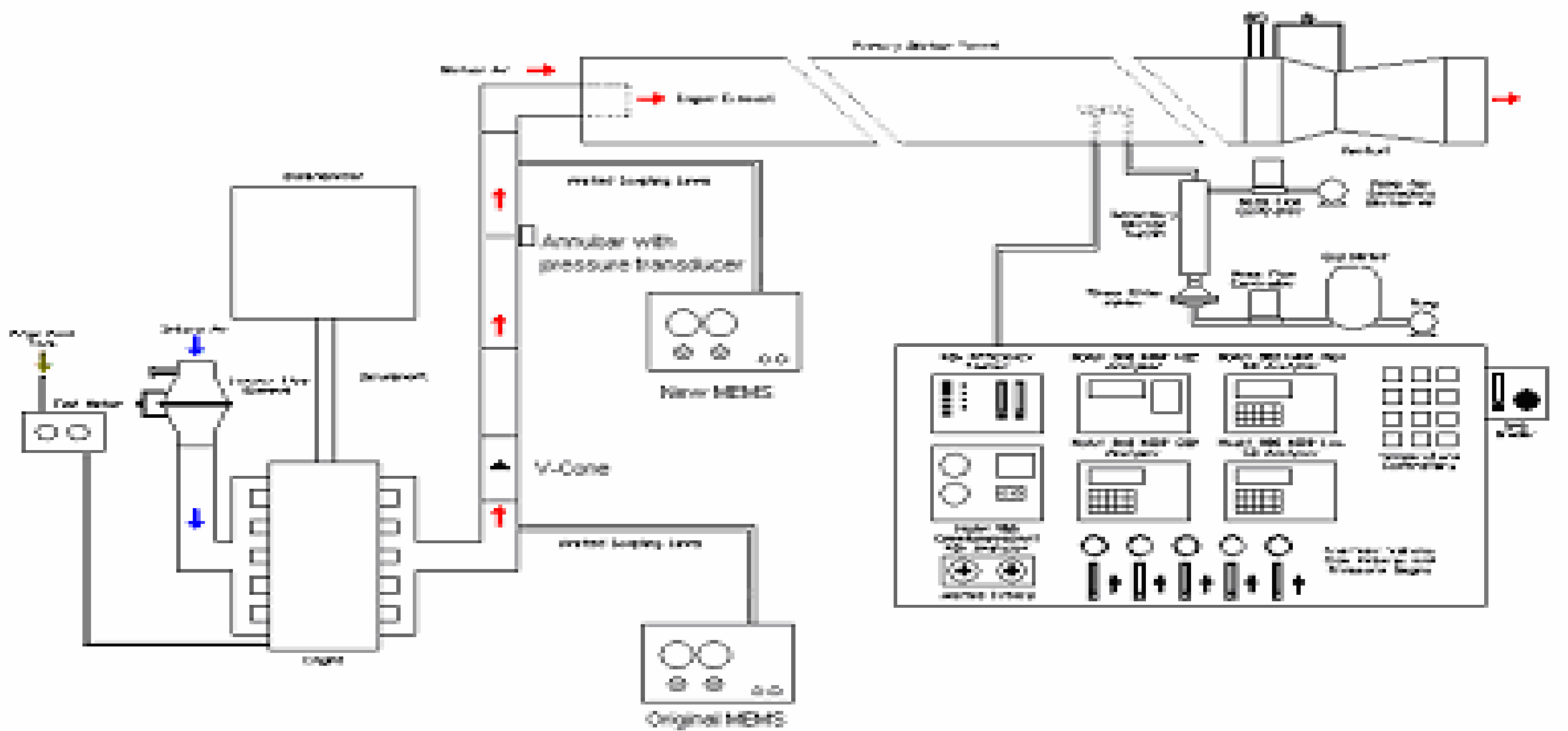

Figure 3.9 Schematic of the test cell at WVU's EERL. The flow path is shown as well. 


\subsubsection{Full Flow Dilution Tunnel}

Exhaust, in the atmosphere, is diluted once it is expelled from the vehicle; it is not raw exhaust. The exhaust gets diluted with the ambient air around that vehicle as it leaves the tailpipe. The dilution tunnel simulates this dilution process; therefore, the emissions results collected from the dilution tunnel are as accurate as can be obtained to picture real world situations. Another advantage of the dilution tunnel is that it lowers the dew point of the exhaust; hence it helps to prevent constituents from condensing out in the sample lines.

WVU's EERL is equipped with a total exhaust, double-dilution tunnel, designed to meet CFR 40 Part 86 Subpart N [9] requirements. It is constructed of stainless steel. It has a diameter of 18 inches, and is 40 feet in length. A blower pulls the exhaust as well as ambient air through the tunnel. Four critical flow venturi regulate the flow that the blower pulls. The exhaust exits the exhaust system at the entrance of the tunnel. There is one $400 \mathrm{scfm}$ venturi and three $1000 \mathrm{scfm}$ venturi's to regulate the flow between 400 and $3400 \mathrm{scfm}$. The end of the exhaust pipe is situated in the center of the tunnel opening, and an orifice is located three feet downstream for mixing purposes. Ports are located along the tunnel, at least 15 feet downstream of the orifice, to extract a sample of diluted exhaust for measurement purposes. Pumps draw the sample to the gas analyzers that include $\mathrm{CO}, \mathrm{CO}_{2}, \mathrm{NO}_{\mathrm{X}}$, and $\mathrm{HC}$. Another pump draws a sample through a smaller tunnel across a filter to collect total PM data. Heated lines are used to transport the sample 
exhaust to the analyzers (to prevent constituents from condensing out in the lines prior to the sensors).

\subsubsection{Engine Dynamometer}

For emissions data to represent the emission emitted from an on-road vehicle, the engine test where emissions data is measured must represent the engine operating onroad. Therefore, the dynamometer must load the engine in a manner to simulate a driving cycle. WVU's EERL utilizes a General Electric model DYC 243 air-cooled, direct current (DC) dynamometer. It is capable of absorbing $550 \mathrm{hp}$, and providing $500 \mathrm{hp}$ when motoring the engine. RPM is measured using a digital encoder inside the dynamometer, while torque is measured by using a load cell.

\subsubsection{Critical Flow Venturi}

CFR 40 Part 86 subpart N [9] requires a constant volume sampling system. WVU's EERL uses the critical flow venturi as compliance to regulate dilute exhaust flow. Three venturi are used for constant total flow rate. Critical flow venturi operate on the theory that the mass flow rate of a gas is maintained at a constant value once that gas flow reaches sonic conditions. The mass flow rate can be calculated from a calibration coefficient, pressure, and temperature.

\subsubsection{Gaseous Measurement System}

The gaseous sampling system of the EERL consists of heated sampling probes, heated sample lines, heated head pumps, heated filters, a water-removing device, and gas analyzers. Stainless steel sample probes are inserted into the dilution tunnel to draw a sample of diluted exhaust. Three probes are used, one for $\mathrm{HC}$, one for $\mathrm{NO}_{\mathrm{X}}$, and one for 
$\mathrm{CO} / \mathrm{CO}_{2}$. Heated lines transfer the sample to the analyzers and are kept at a constant temperature. For $\mathrm{NO}_{\mathrm{X}}$ and $\mathrm{HC}$, the line is kept at $375^{\circ} \mathrm{F}+/-10^{\circ} \mathrm{F}$, and for $\mathrm{CO} / \mathrm{CO}_{2}$ $235^{\circ} \mathrm{F}$. The heated pumps are also controlled at a constant temperature. A Hankison compressed-air dryer was used to remove water from the $\mathrm{CO} / \mathrm{CO}_{2}$ sample line.

\subsubsection{Gaseous Measurement Instruments}

\subsubsection{Hydrocarbon Analyzer}

The EERL uses a Rosemount Analytical Model 402 heated flame ionization detector (HFID) to measure hydrocarbons in the exhaust. The Model 402 has an internal pump and heated filter. The internal chamber is maintained to $375^{\circ} \mathrm{F}$ to prevent any condensation issues.

An HFID uses an internal flame to ionize the carbon atoms in the exhaust sample. Electrons and positive ions are produced from the ionizing flame. The electrons are drawn to a positively charged electrode and the positive ions are drawn to a negatively charged electrode. A small ionization current is produced between the electrodes which is directly proportional to the concentration of $\mathrm{HC}$ atoms. This current is measured by electronic circuitry which is related to $\mathrm{HC}$ concentrations. The Model 402 can measure HC concentration up to 250,000ppm.

\subsubsection{2 $N O_{X}$}

The $\mathrm{NO}_{\mathrm{X}}$ analyzer the EERL uses is a Rosemo unt Model 955 chemiluminescent analyzer. There is an internal $\mathrm{NO}_{\mathrm{X}}$ converter within the analyzer that allows the analyzer 
to convert $\mathrm{NO}_{2}$ to $\mathrm{NO}$, thus allowing the analyzer to measure $\mathrm{NO}_{\mathrm{X}}$. A solenoid switch, within the analyzer, can divert the sample gas around the $\mathrm{NO}_{\mathrm{X}}$ converter to allow the analyzer to measure only $\mathrm{NO}$, since the analyzer cannot measure $\mathrm{NO}_{2}$.

Chemiluminescence results when light is a product in a chemical reaction [27]. The Model 955 measures $\mathrm{NO}_{\mathrm{X}}$ concentrations by determining the chemiluminesent radiation over a small region of the total emissions through the use of bandpass filter and photomultiplier. Ozone $\left(\mathrm{O}_{3}\right)$ is generated by the ultraviolet irradiation of oxygen in a quartz tube. To ensure complete reaction, excess $\mathrm{O}_{3}$ is present in the chamber and it also minimizes quenching effects. Sample pressure and flow rate must be carefully monitored, as the photomultiplier is proportional to the number of NO atoms in the sample, rather than the concentration of NO in the sample. A problem with the Model 955 is that it does not measure $\mathrm{NO}_{2}$, as $\mathrm{NO}_{2}$ does not react with the ozone like $\mathrm{NO}$ does. A portion of $\mathrm{NO}_{\mathrm{X}}$ (from 2\%-10\%) in diesel exhaust is $\mathrm{NO}_{2}$. Therefore, in the Model 955 the $\mathrm{NO}_{\mathrm{X}}$ converter reduces $\mathrm{NO}_{2}$ to give total $\mathrm{NO}_{\mathrm{X}}$ measurements. If concentrations of $\mathrm{NO}$ are only desired, the sample can be diverted around the $\mathrm{NO}_{\mathrm{X}}$ converter to give only NO concentrations. The Model 955 can measure $\mathrm{NO}_{\mathrm{X}}$ concentrations in full-scale ranges of $10,25,100,250,1000,2500$, and 10000ppm.

\subsubsection{Horiba Model AIA-210-10-LLCO}

The Horiba Model AIA-210-10-LLCO is a non-dispersive infrared analyzer (NDIR) to continuously measure the concentrations of individual components of the sample gas. There are two detection cells, a reference cell and a sample cell. A light source supplies infrared light to the detection cells through a chopper wheel to give 
intermittent light to the cells. As the sample gas absorbs light energy in the cell, there is a difference in intensity between the sample cell and the reference cell. This absorption allows only a certain wavelength of the infrared light to reach the detector. This difference between the sample cell and the reference cell is directly related to the concentration of a certain component of the sample gas. If another component in the sample gas overlaps the wavelength of the desired component measurement, a solid state filter removes those overlapping infrared wavelengths so that they do not affect the concentration measurements.

\subsubsection{Horiba Model AIA-210 $\mathrm{CO}_{2}$}

The $\mathrm{CO}_{2}$ analyzer is a Horiba Model AIA-210 NDIR Analyzer. The Model AIA210 operates with an NDIR detection scheme. The NDIR detector is a spectrophotometer that uses a filter to measure light absorption over a small range of wavelengths. Different gases, or different components of gases, absorb different bands of infrared light, with some of those gases overlapping small regions. The detection mechanism consists of a light source, a filter, two cells (a sample cell and a reference cell), and a chopper wheel. The gas sample enters the sample cell, where infrared light is passed through it. Infrared light is also passed through the reference cell, which contains a gas that does not absorb the same wavelength that is being absorbed in the sample cell. Light energy will be reduced when the gas under observation will absorb some of the light in the sample cell. The ratio of the detector cells can them be related to the gas concentration in the sample cell. 


\subsubsection{Bag Sampling}

Bag sampling allows the EERL to eliminate the constituents of ambient air that add to the concentrations measured in the exhaust. Tedlar Bags with 80-liter capacity are used to collect ambient air. The gaseous analyzers then sample the ambient air to measure the exhaust constituents in the ambient air. This value is then subtracted from the results of the constituents in the engine exhaust to obtain emissions of just the engine.

\subsubsection{Fuel and Air Sampling}

Fuel and intake air are measured by Max Machinery, Inc Max Model 710 fuel conditioning system and a Meriam Instruments laminar flow element (LFE). The fuel conditioning system consists of a constant volume fuel tank, fueling supply and return lines, fuel pump, fuel meter, and heat exchanger. It interfaces with the data acquisition computer to give fuel measurements. The LFE utilizes the differential pressure principle, with absolute pressure and temperature at the inlet, to calculate the flow.

\subsubsection{Data Acquisition}

The EERL data acquisition consists of Analog Devices 3B system modules for signal conditioning. An RTI-815 analog-to-digital converter is used to change the analog inputs from the instruments to a digital output. The data is recorded in ADC code. A separate data reduction program is used to convert the ADC code into engineering units. 


\subsection{Error Analysis}

Absolute and root-sum square basis was used for determination of the propagation of uncertainty. Absolute error is calculated by taking the sum of the absolute values of error contributed by each variable in the equation. The absolute error is given by:

\section{Equation 7}

$$
E_{a}=\left|\Delta u_{1} \frac{\partial f}{\partial u_{1}}\right|+\left|\Delta u_{2} \frac{\partial f}{\partial u_{2}}\right|+\ldots\left|\Delta u_{n} \frac{\partial f}{\partial u_{n}}\right|
$$

The root-sum square formula is the combination of random and bias errors. Random error is errors contributed by fluctuations in the repeatability of a measurement, and bias error is the actual offset of the measurement compared to the "true" value. The root-sum square formula is given by Equation 2:

\section{Equation 8}

$E_{a_{s s}}=\left[\left(\Delta u_{1} \frac{\partial f}{\partial u_{1}}\right)^{2}+\left(\Delta u_{2} \frac{\partial f}{\partial u_{2}}\right)^{2}+\ldots\left(\Delta u_{n} \frac{\partial f}{\partial u_{n}}\right)^{2}\right]^{1 / 2}$

Random errors are usually accounted for by using normal distribution. For example, a $95 \%$ probability means that $95 \%$ of the data points would be within the calculated error range. A variable, $\mathrm{z}$, calculated from the mean value, value at the point of interest, and the standard deviation is 1.96 . The resulting root-sum square formula is: 


\section{Equation 9}

Total Error $=\left(\left(\text { Bias }_{1}\right)^{2}+\left(\text { Bias }_{2}\right)^{2}+\ldots+\left(\text { Bias }_{n}\right)^{2}\right)^{1 / 2}+$

$1.96\left(\left(\text { Random }_{1}\right)^{2}+\left(\text { Random }_{2}\right)^{2}+\ldots+\left(\text { Random }_{n}\right)^{2}\right)^{1 / 2}$

The error obtained in Equation 9, is not the error of the analyzer, it is the possible error in the gaseous concentration being measured. Equation 10 shows the errors associated with the measurement of $\mathrm{CO}_{2}$.

\section{Equation 10}

$\Delta C O_{2}=\left[(0.005 * 12)^{2}+(0.01 * 12)^{2}\right]^{1 / 2}+1.96\left[(0.002 * 12)^{2}\right]^{1 / 2}=0.18 \% C \mathrm{CO}_{2}$

Table 3.2 shows the errors involved in the reporting of gaseous emissions.

Table 3.2 Errors involved in reporting gaseous emissions errors.

\begin{tabular}{|l|l|l|}
\hline Analyzer & Accuracy (Random) & Repeatability (Bias) \\
\hline Calibration Gas & N/A & $\pm 1.0 \%$ Gas Bottle Conc. \\
\hline \hline Analyzer & $\pm 1.0 \%$ of Full Scale & N/A \\
\hline Gas Divider & $\pm 0.2 \%$ of Full Scale & $\pm 0.5 \%$ of Full Scale \\
\hline Total Error & $\pm 1.22 \%$ of Full Scale & $\pm 1.5 \%$ of Full Scale \\
\hline
\end{tabular}




\subsection{Test Procedure}

\subsubsection{HFID Test Procedures}

Steady state, transient, and response and drift tests were conducted to evaluate the Signal Model 3030PM HFID analyzer. A transient test will give a better representation of real world driving, while steady state test provide better instrument comparison because the engine will hold constant conditions for a length of time allowing the analyzer to be compared at different conditions. The response and drift tests show different characteristics of the instrument.

The transient test used for the evaluation of the HFID analyzer was an US Federal Test Procedure, the USFTP. It is recognized that the heavy-duty engine certification cycle, the USFTP, is not representative of current on-road vehicle/engine performance; it is a test schedule that is most commonly employed. For the steady state test cycles, a 6mode multipoint cycle was used. Only 5 modes were used to collect data, as the $6^{\text {th }}$ mode was an idle.

The response test that was used to evaluate the response of the HFID analyzers involved a gas divider and manually changing the concentration from zero air to the span gas. Each concentration level was held for one-minute. Since both HFID's sampled from the same port, the span gas flooded the sample probe, making sure that more sample gas was presented than sampled by the analyzers. Twenty minute tests were performed, with the analyzers measuring the known concentration. The drift test was done to quantify the drift that each instrument had. 


\subsubsection{V-Cone Test Procedures}

Similarly to the hydrocarbon analyzer testing, both steady state and transient test cycles were used to evaluate the flow meters. Steady state tests provide for better comparisons of the two flow meters. Steady state test cycles allow a more controlled test because the engine holds conditions constant for a given length of time. Transient tests, on the other hand, give more of a real world driving scenario.

\subsubsection{Preliminary Test Procedures}

For the preliminary testing, different steady state and transient tests were used. The steady state test cycle was a three mode cycle with an idle as before and after the modes. Figure 3.10 shows the speed and torque of the test. 


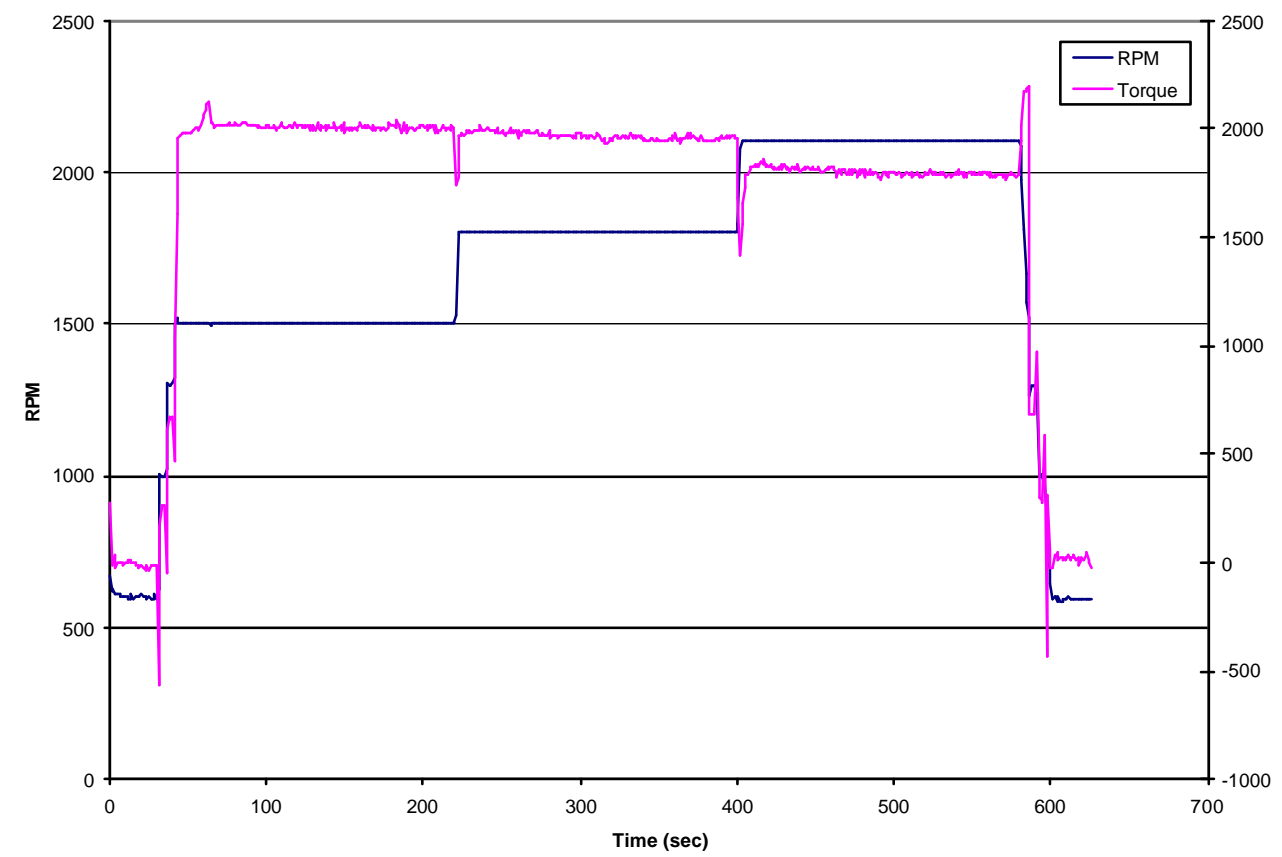

Figure 3.10 Real-time rpm and torque for the steady state test cycle.

A transient cycle was developed by researchers at WVU (Gautam, et al., 2002 [15]) to simulate in-field operation of a track-type dozer. The test cycle RPM and torque data can be seen in Figure 3.11. Both of these test cycles were for the preliminary testing conducted for the flow meters. 


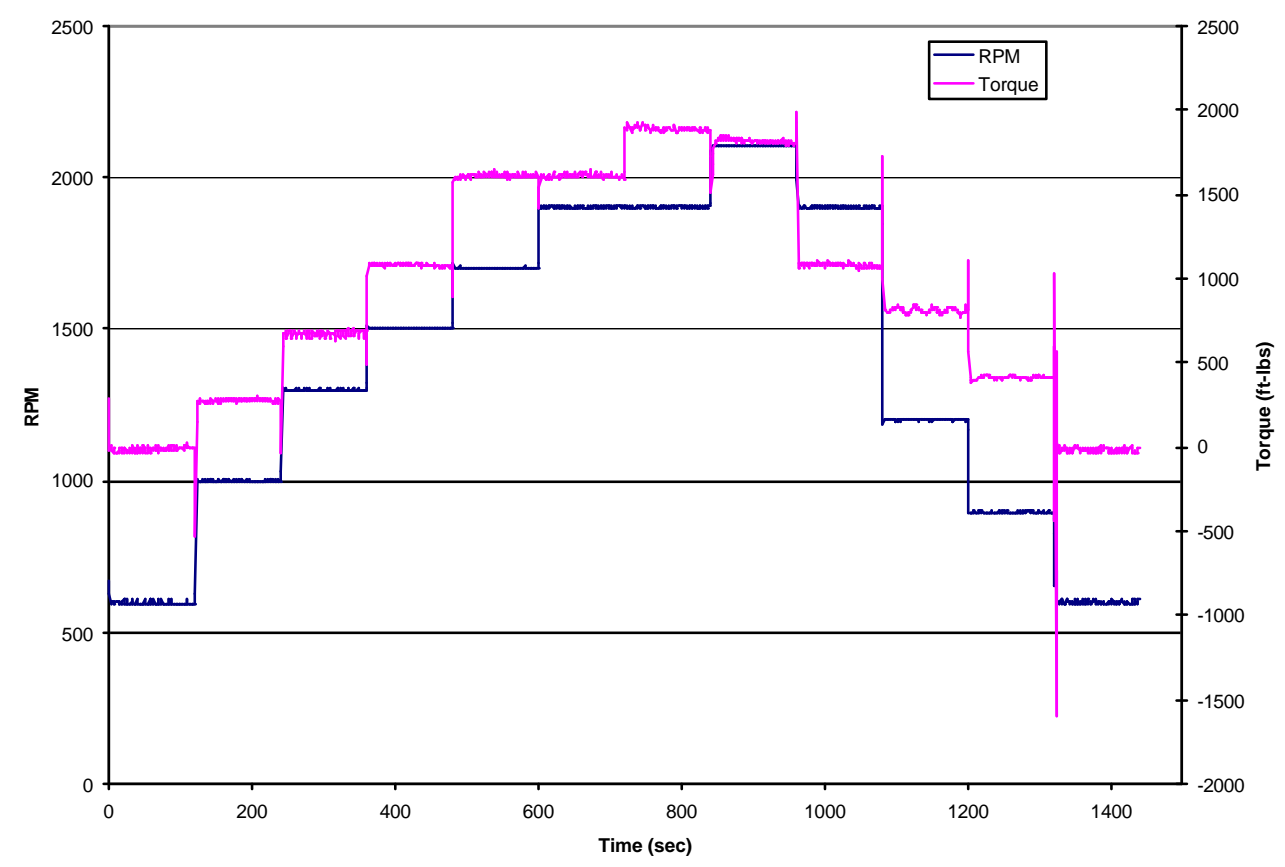

Figure 3.11 Real-time rpm and torque data for the dozer test cycle.

\subsubsection{Testing Conducted September 2002}

For this testing, the transient test cycle used in this series of tests was recreated from an actual on-road operation of a class-8 tractor. Specifically, the transient cycle was developed from the first leg of the Washington, PA route that was developed for the consent decrees work that is being conducted at WVU. This cycle was called the PA1 cycle. Five tests were conducted using this cycle. The cycle RPM and torque data can be seen in Figure 3.12. 


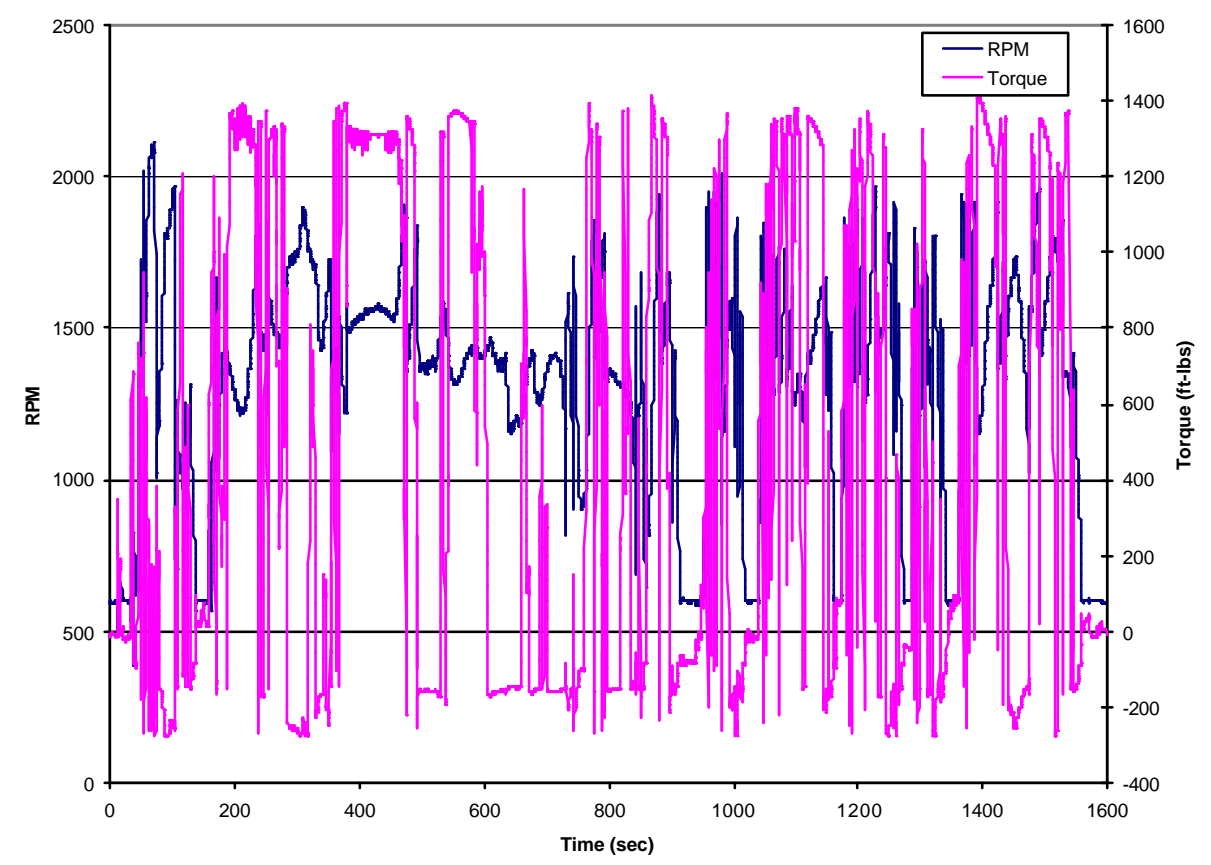

Figure 3.12 Real-time speed (rpm) and load (ft-lbs) for the transient test cycle, the Washington, PA route.

A steady state cycle was also developed specifically for this testing. The steady state test cycle included 9 modes with an idle at the beginning and the end of each cycle. Each mode, including the idle set points, is approximately 2 -minutes in length. The modes varied in the load and speed of the engine. Table 4.1 shows the load and speed of each mode. Figure 3.13 shows the real time RPM and torque data for the 9-mode steady state test. 


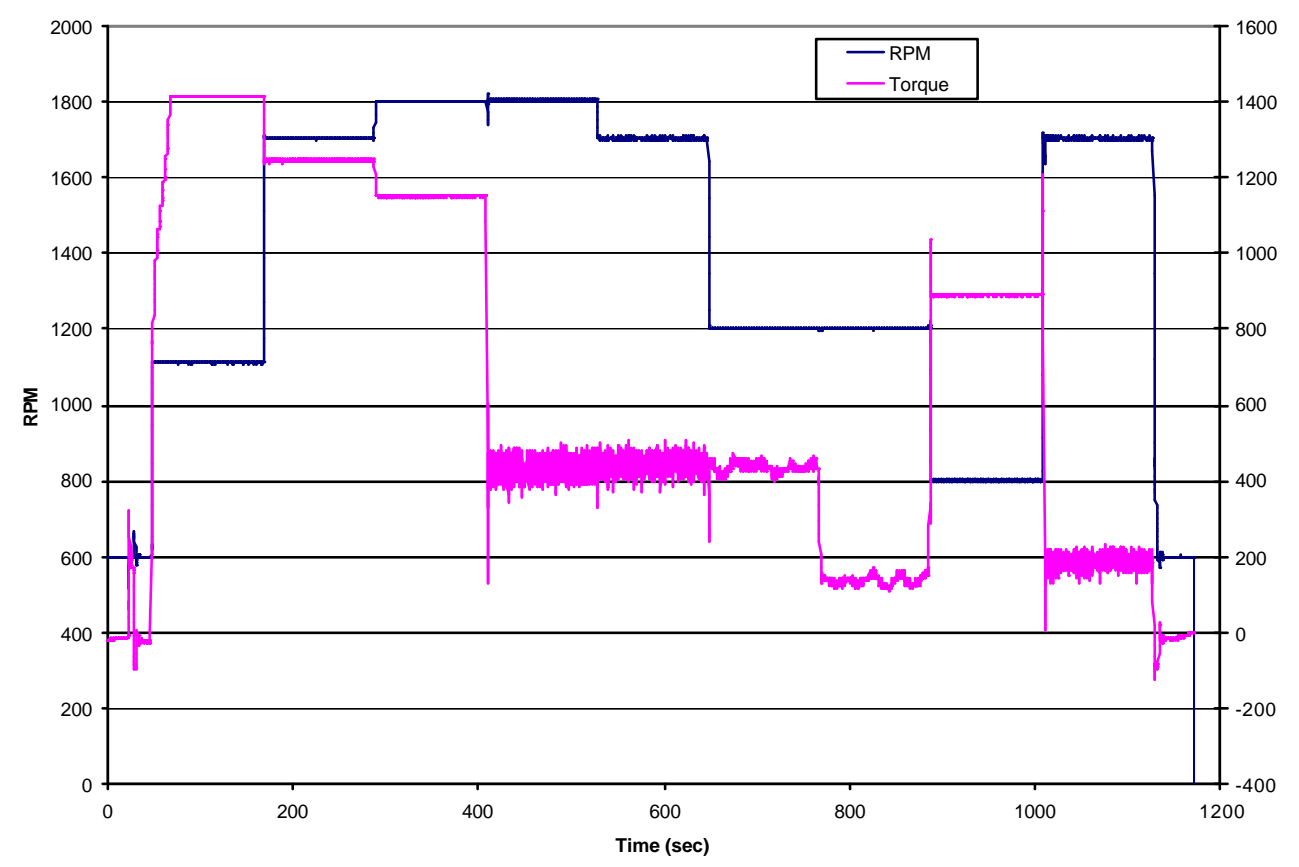

Figure 3.13 Real-time rpm and torque data for the 9-mode steady state test.

Table 3.3 Speed and load set points for the VolvoSS2 test cycle.

\begin{tabular}{|r||c||c||}
\hline Mode & Speed (RPM) & Load (ft-lbs) \\
\hline \hline Idle & 600 & max \\
\hline \hline Mode 1 & 1110 & $\max$ \\
\hline \hline Mode 2 3 & 1700 & $\max$ \\
\hline \hline Mode 4 & 1800 & 450 \\
\hline \hline Mode 5 & 1800 & 450 \\
\hline \hline Mode 6 & 1700 & 450 \\
\hline \hline Mode 7 & 1200 & 150 \\
\hline \hline Mode 8 & 1200 & $\max$ \\
\hline \hline Mode 9 & 800 & 5 \\
\hline \hline Idle & 1700 & 50 \\
\hline \hline
\end{tabular}




\section{Chapter 4 Results and Discussion}

\subsection{Hydrocarbon Analyzer HFID Validation Testing}

The Signal Model 3030PM hydrocarbon analyzer was tested at WVU's Engine and Emissions Research Laboratory (EERL) and the results were compared with a Rosemount Analytical 402 hydrocarbon analyzer, which the Laboratory is currently using. A Detroit Diesel Corporation Series 60 diesel engine was operated over both the steady state and transient cycles. A 6-mode multipoint steady-state cycle was run for the steady state testing and an USFTP cycle for the transient testing.

Both the Signal and the Rosemount Analytical hydrocarbon analyzers sampled from the same port located in the dilution tunnel. Drawing samples from the same port, allowed for a direct comparison of the analyzers. The Rosemount Analytical 402 analyzer is integrated in the EERL data acquisition system. The system uses a 12 bit analog to digital board to convert the analog signal from the analyzer to a digital output (0 to 2000 ADC code). The analyzers are calibrated with the span value equal to the ADC code of 2000, and the zero value is assigned an ADC code of 0 . The EERL assigns channels to each instrument that is used in the Laboratory. The Rosemount Analytical analyzer was connected to the permanent hydrocarbon channel in the laboratory, while the Signal was wired into the permanent secondary hydrocarbon channel.

Prior to the test, each analyzer was calibrated. Note that the analyzers display different units of concentration. The Signal analyzer read methane equivalent while the Rosemount Analytical 402 measured percentage of span. Therefore, the Signal read a sample gas of 20 ppm propane as 60 ppm methane equivalent, and the Rosemount 
Analytical 402 measured the percentage of the span. In the data reduction program, the percent reading of the Rosemount Analytical was converted back to a ppm concentration.

\subsubsection{Response Test}

A test was run to check the response times for the Rosemount Analytical and Signal hydrocarbon analyzers. A 20 ppm propane span gas was used with helium as the zero air constituent, since helium is hydrocarbon free. A gas divider, Stec, Inc. Model SGD-710C, was used to physically alternate the change in concentration of the sample gas from hydrocarbon free sample to span gas. The sample gas was allowed to stabilize for a minute before the concentration was changed. This step response can be seen in Figure 4.1. Figure 4.2 shows a single pulse of the concentration change.

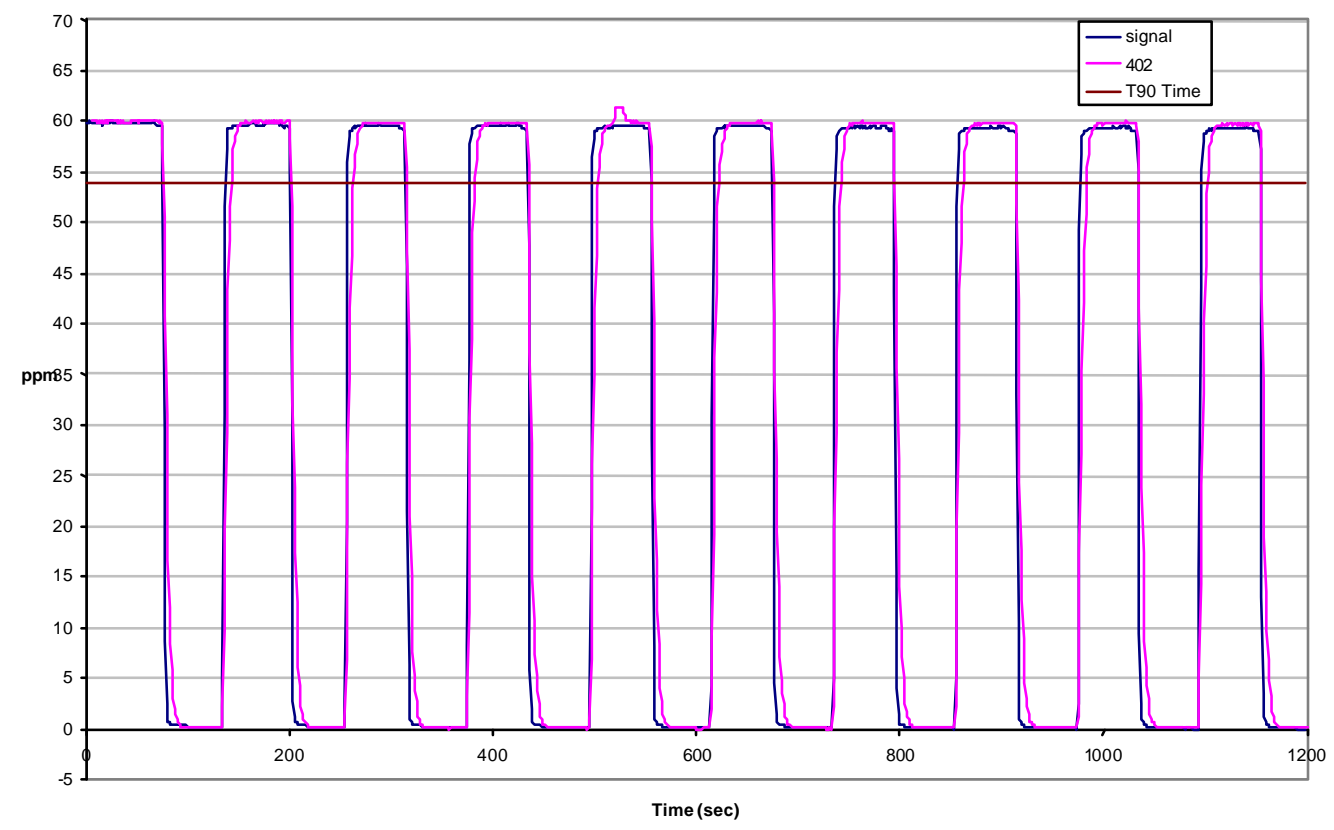

Figure 4.1 The response test using a span gas of $20 \mathrm{ppm}$ propane. 


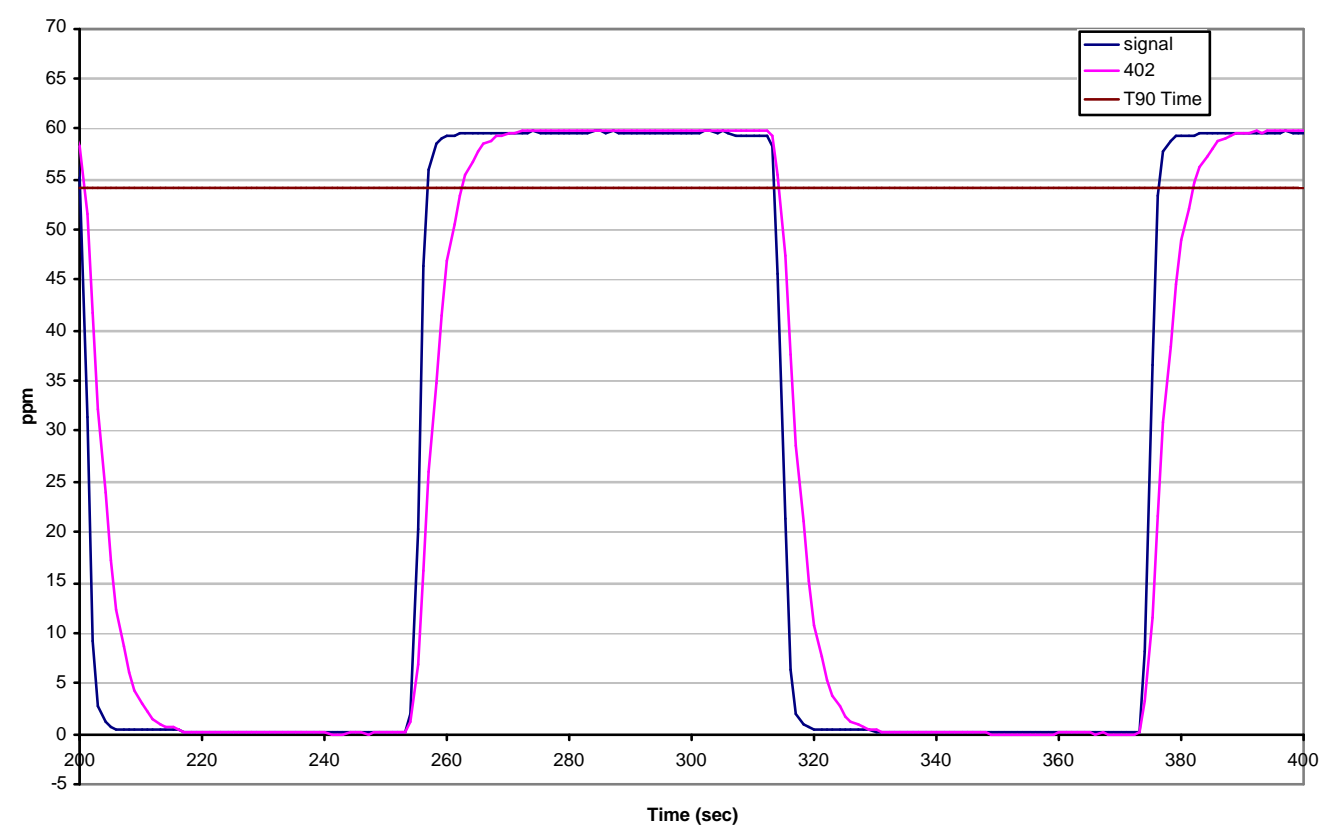

Figure 4.2 A small scale time frame of the response test showing the response of the instruments.

The $\mathrm{T}_{90}$ time is the time for the analyzer to reach $90 \%$ of the set value. For the response test, the $\mathrm{T}_{90}$ time was found from inspecting the plots of the response test. For the Rosemount Analytical, the $\mathrm{T}_{90}$ time was 9 seconds, while the $\mathrm{T}_{90}$ time for the Signal was 3 seconds. The Rosemount Analytical analyzer achieves close to $100 \%$ of the span on each concentration change, while the Signal shows a slight drift from span. The error between the analyzers when span gas was the sampled gas was less than $1 \%$.

\subsubsection{Drift Test}

The analyzers also were tested for drift. Drifting is when a constant concentration of gas is sampled by the instrument, but the instrument starts to change, or drift, from the true concentration. Two separate drift tests were conducted. A zero air drift test was a 20 minute test where the analyzers sampled zero air or hydrocarbon free air. The other 
drift test was a span drift test. The instrument samples a span gas, $20 \mathrm{ppm}$ propane, for 20 minutes. Figure 4.4 shows the zero air drift test while Figure 4.6 shows the span gas drift test.

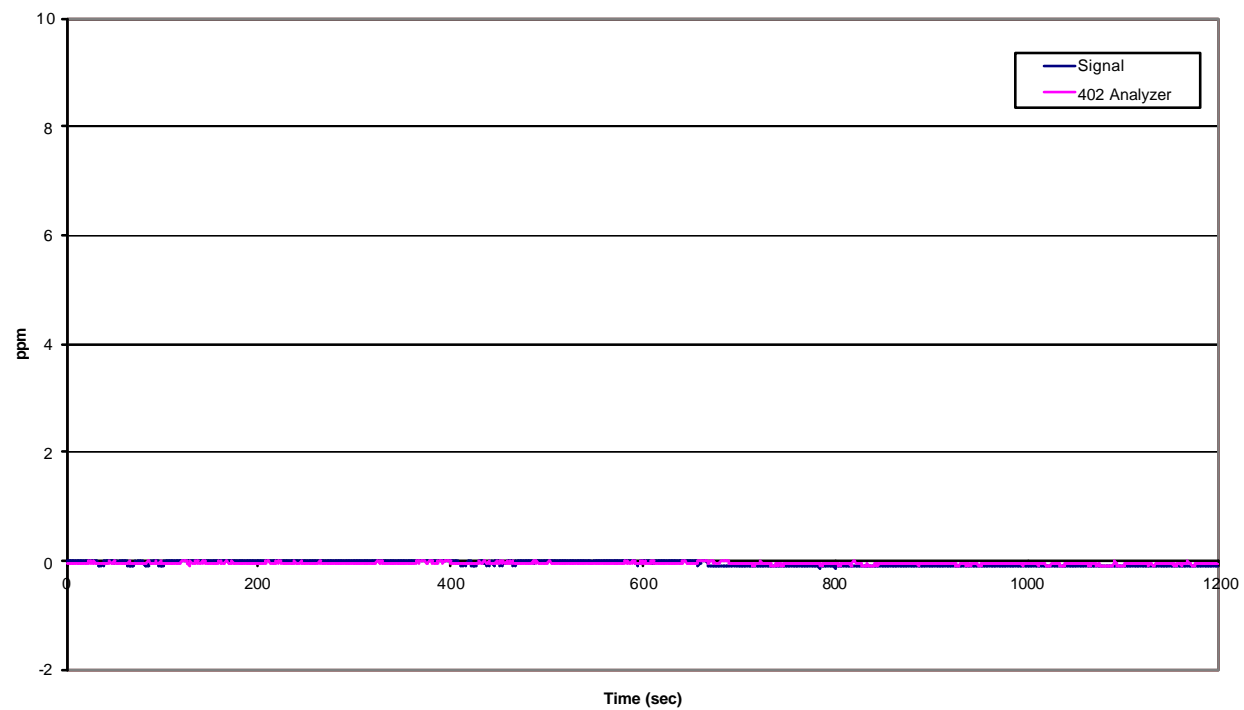

Figure 4.3 Hydrocarbon comparison of the HFID for a zero air drift test, showing a scale up to $10 \mathrm{ppm}$.

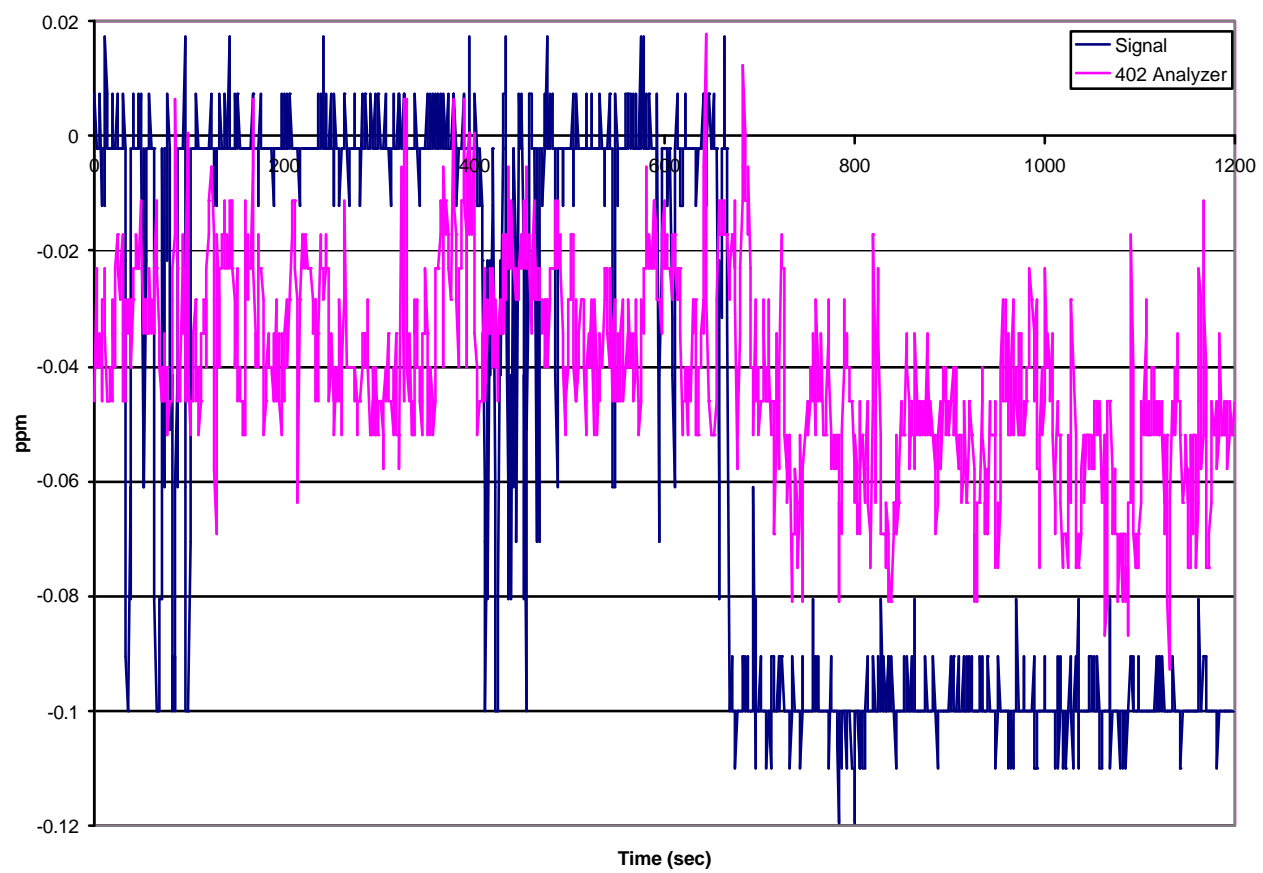

Figure 4.4 Hydrocarbon comparison of the HFID for a zero air drift test. 


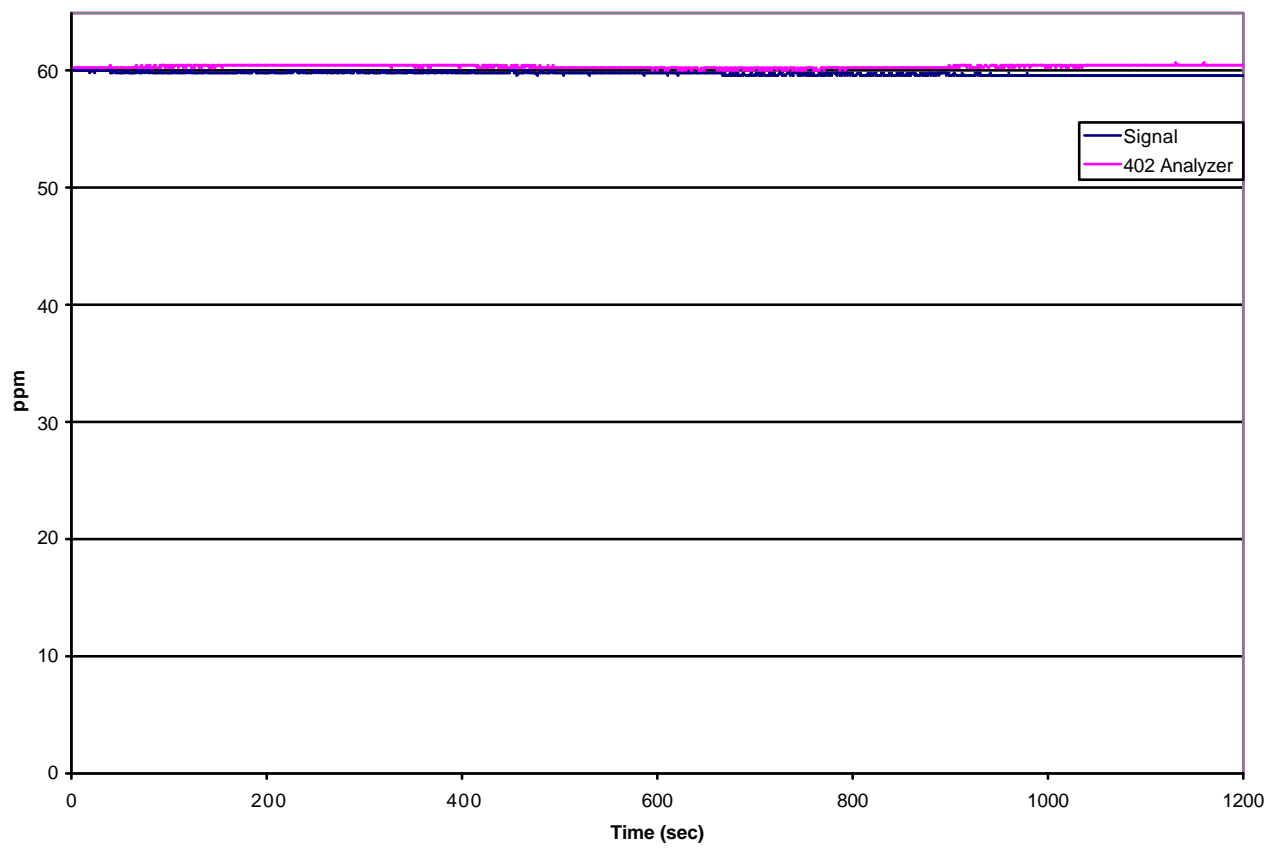

Figure 4.5 Hydrocarbn comparison of the HFID for a span drift test.

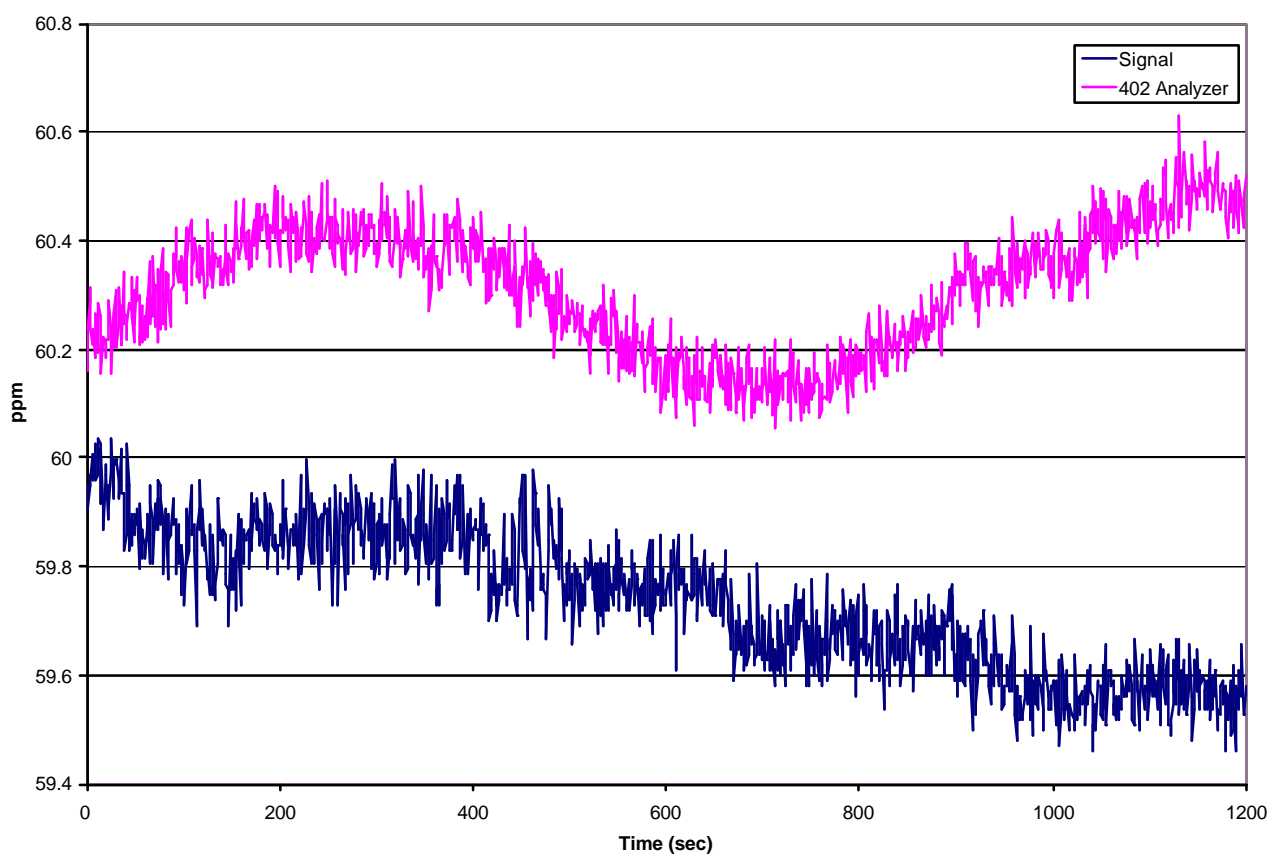

Figure 4.6 Hydrocarbon comparison of the HFID for a span gas drift test, reduced scale. 
Figure 4.5 and Figure 4.6 show that neither instrument drifts more than $0.6 \mathrm{ppm}$. The Signal Model 3030PM analyzer drifts a little more than $0.1 \mathrm{ppm}$ during the zero air drift test and about 0.4ppm for the span gas drift test. The Rosemount Analytical 402 analyzer drifts a little more than $0.5 \mathrm{ppm}$ for the zero air drift test and a little over $0.4 \mathrm{ppm}$ for the span gas drift test. An interesting point is the cyclic drift of the Rosemount Analytical 402 analyzer during the span gas drift test. The Rosemount Analytical has an internal heater that turns on in a cyclic manner to keep the internal oven of the analyzer above the set temperature. This cyclic drift from the Rosemount Analytical 402 is probably a direct result of the cyclic heating of the internal oven.

\subsubsection{Transient Tests: USFTP}

The USFTP was used to evaluate the Signal Model 3030PM. Several USFTP transient tests were conducted using the Detroit Diesel Corporation Series 60 engine at WVU's EERL. Hydrocarbon data was collected using both the Rosemount Analytical 402 and Signal Model 3030PM for each test. Figure 4.7 and Figure 4.8 show the direct comparison between the Signal and Rosemount Analytical analyzers for two transient tests. 


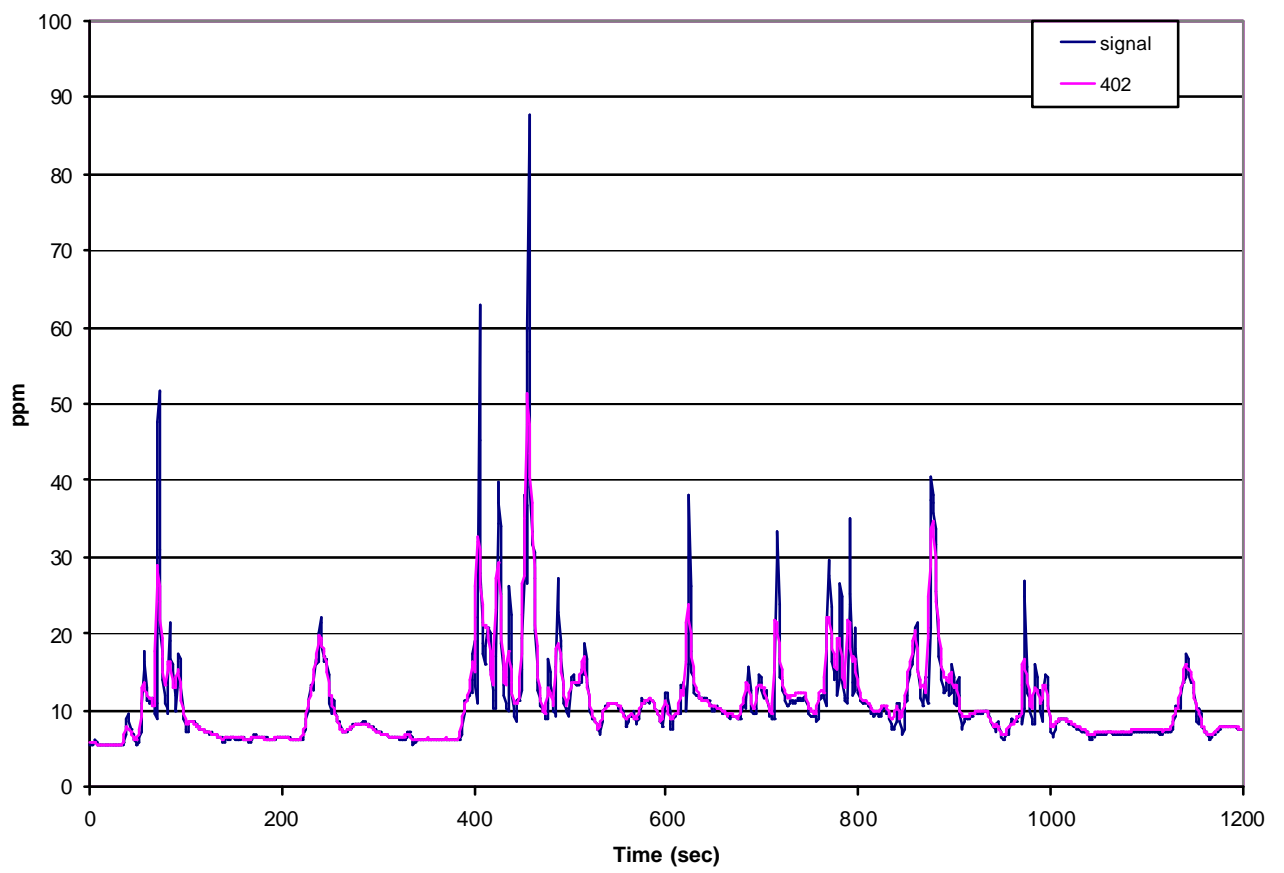

Figure 4.7 Hydrocarbon comparison of the HFID for transient FTP test-1.

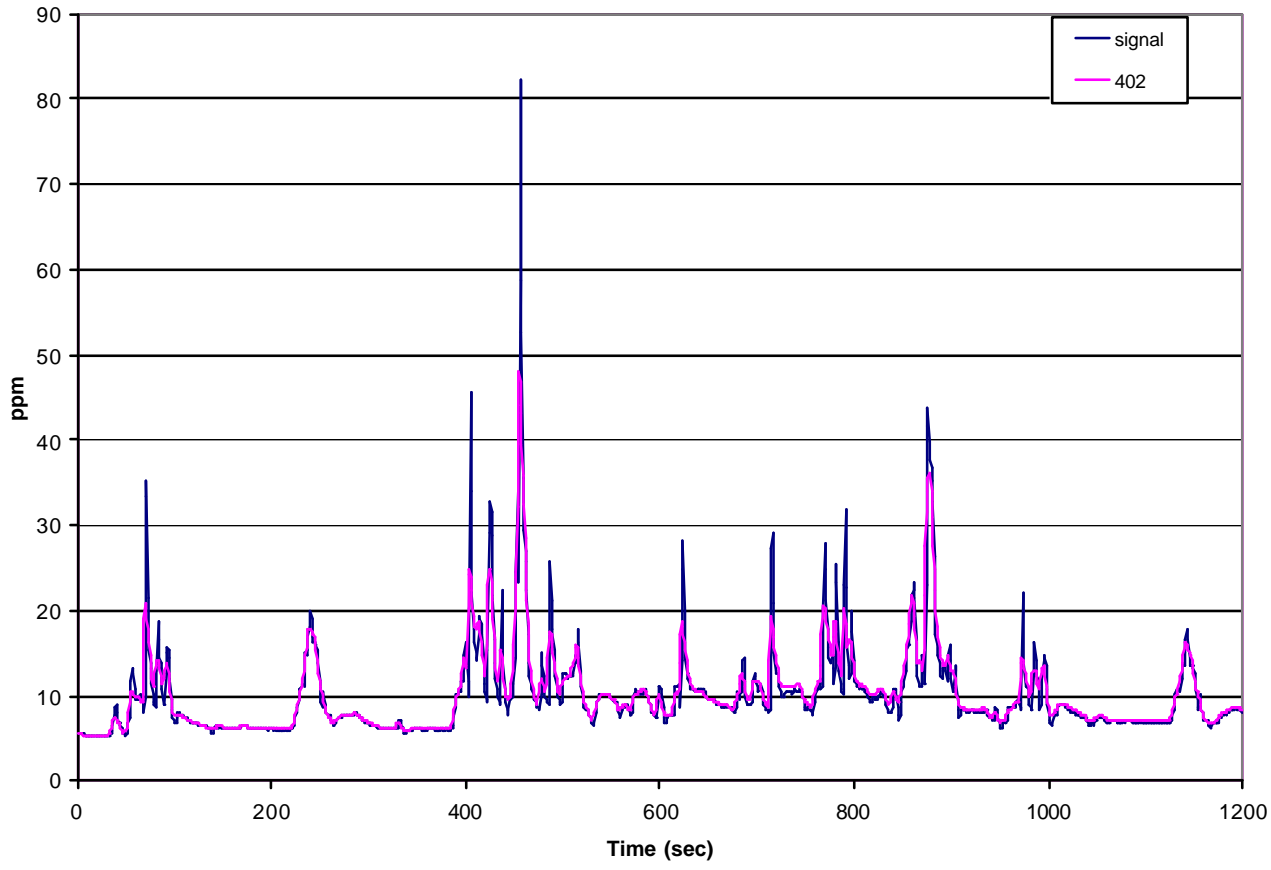

Figure 4.8 Hydrocarbon comparison of the HFID for transient FTP test-2. 
Figure 4.9 shows a 150 second window of a USFTP. The Signal Analyzer captured hydrocarbon emissions over most of the transients, where the Rosemount Analytical gave a smoother trace.

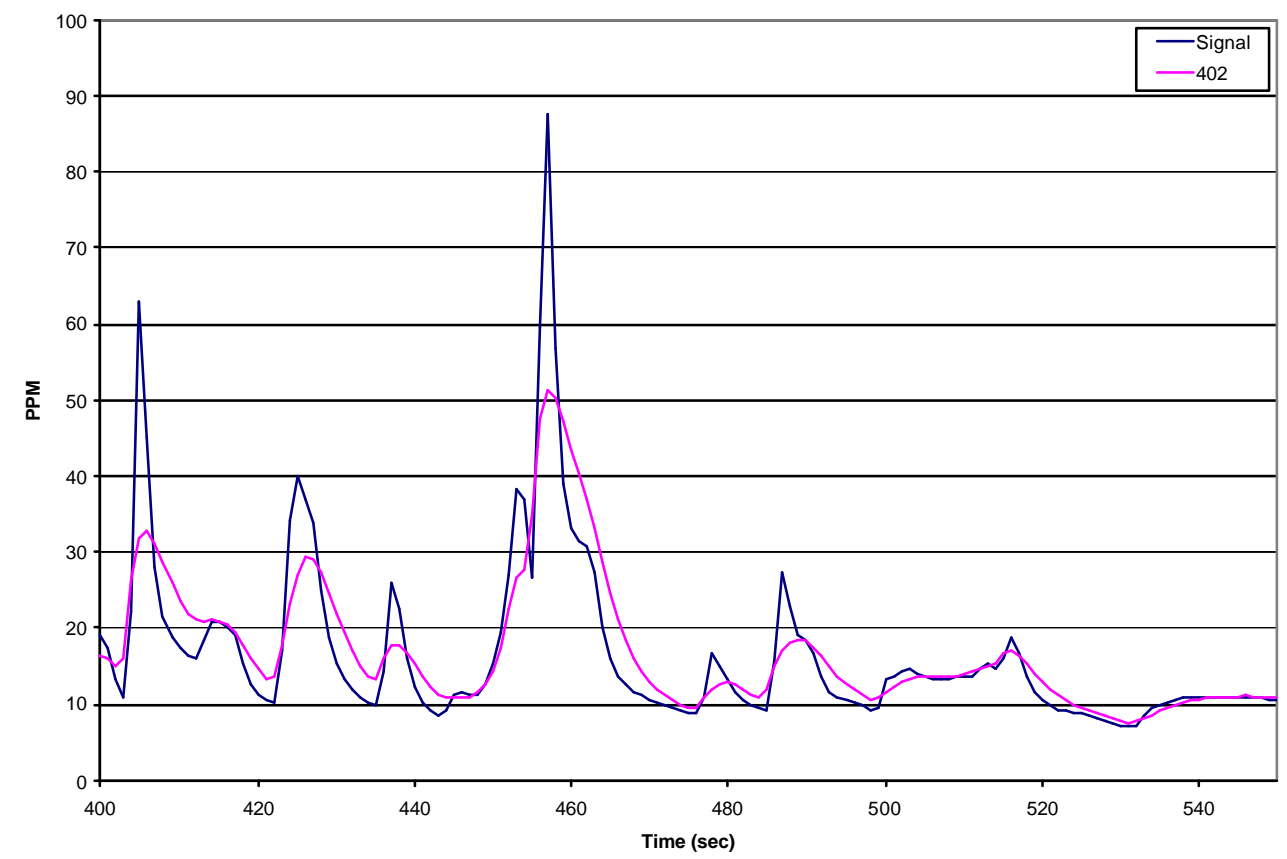

Figure 4.9 A smaller time scale, an 150 second window, of the Hydrocarbon comparison of the HFID analyzers for transient FTP test-1.

Regression analysis plots two sets of data against each other. When plotted the two sets of data will show the relationship between them. The $\mathrm{R}^{2}$ function determines the extent of a linear relationship between two fields over a given period of time. The $\mathrm{R}^{2}$ value gives a numerical assignment to the linearity of the data set. Trend lines can be used to generate an equation that represents the data.

For the transient tests, the $\mathrm{R}^{2}$ values are around 0.70 . This value is low when the ideal $\mathrm{r}$-squared value is 1.00 . One reason that would account for the low r-squared value is the peak differences between the analyzers. Because of the greater response 
capabilities of the Signal Analyzer, great differences between the analyzers are found. The peak differences give differences of greater than $100 \%$. If the peak differences are ignored, the mean error between the analyzers would be less than 5\%. Therefore, the differences between the Signal and Rosemount Analytical values at peaks and valleys cause data points to be off of the trend of the data set, thus lowering the r-squared value. The regression analyses, for the two USFTP transient tests, are found in Figure 4.10 and Figure 4.11.

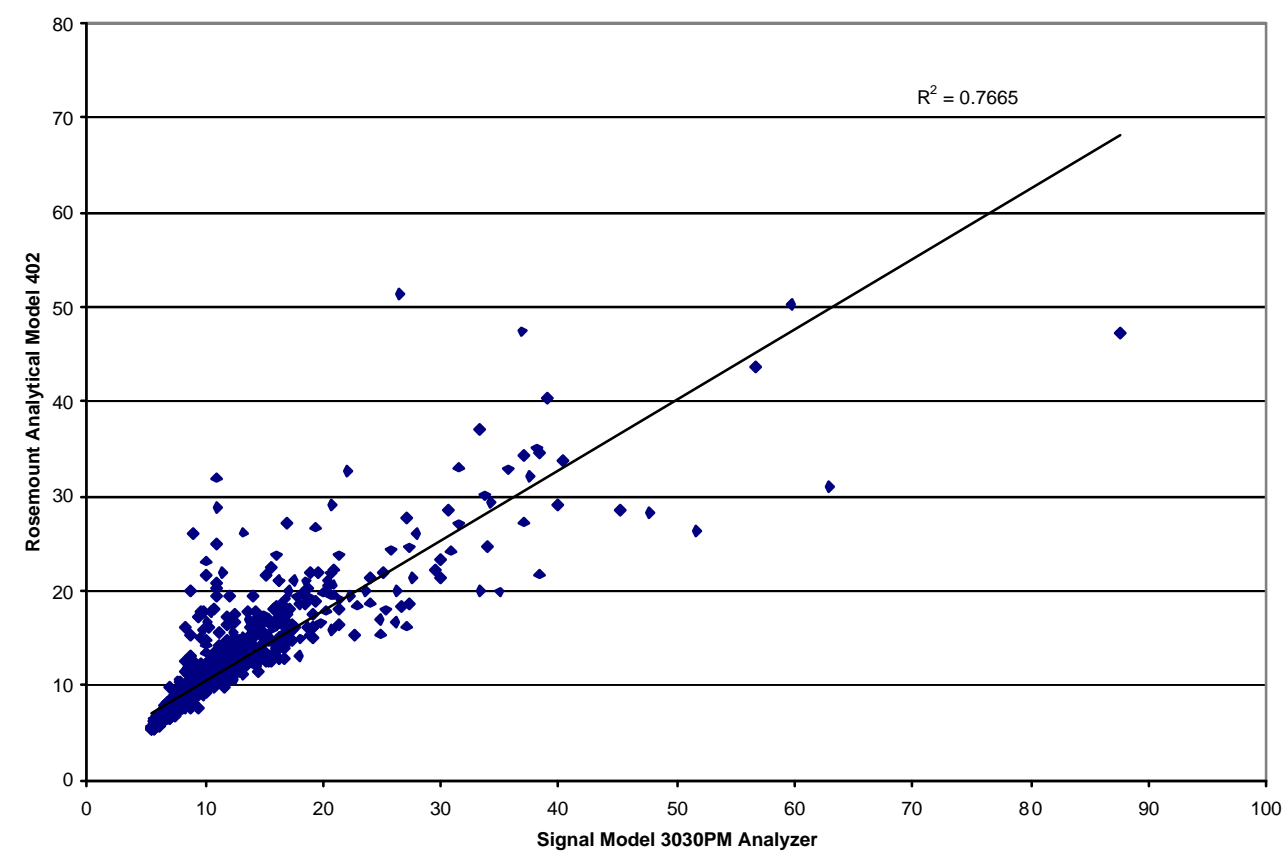

Figure 4.10 Regression analysis of the HFID analyzers for transient FTP test-1. 


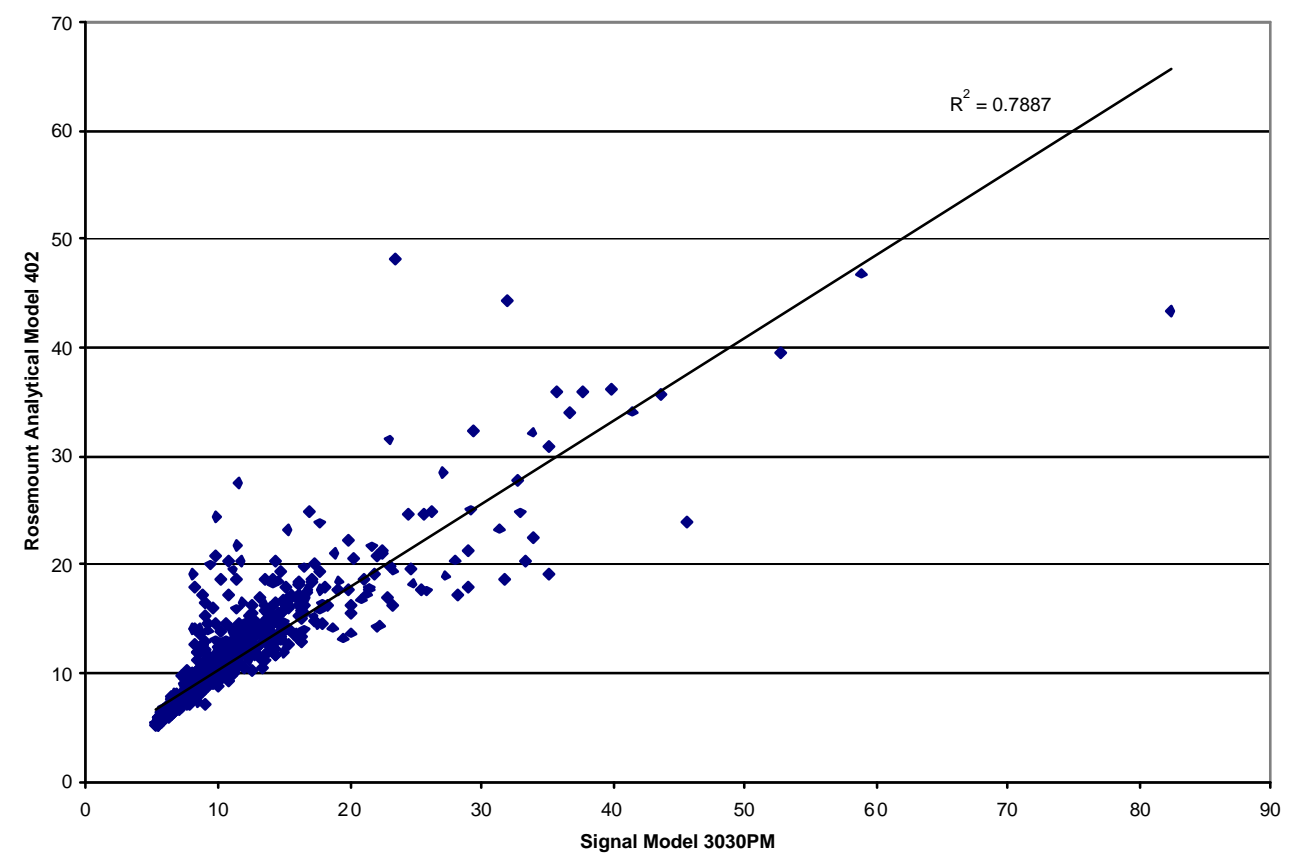

Figure 4.11 Regression analysis of the HFID analyzers for transient FTP test-2. 


\subsubsection{Steady-State Test}

Besides USFTP transient tests, steady-state test cycles were also run and the hydrocarbon analyzers were compared for these cycles as well. For the steady-state cycles, a DDC Series 60 engine was used, the same engine used for the transient tests. Figure 4.12 and Figure 4.13 below show 5 modes in comparison. The $6^{\text {th }}$ mode was idle, and data was not collect over mode- 6 .

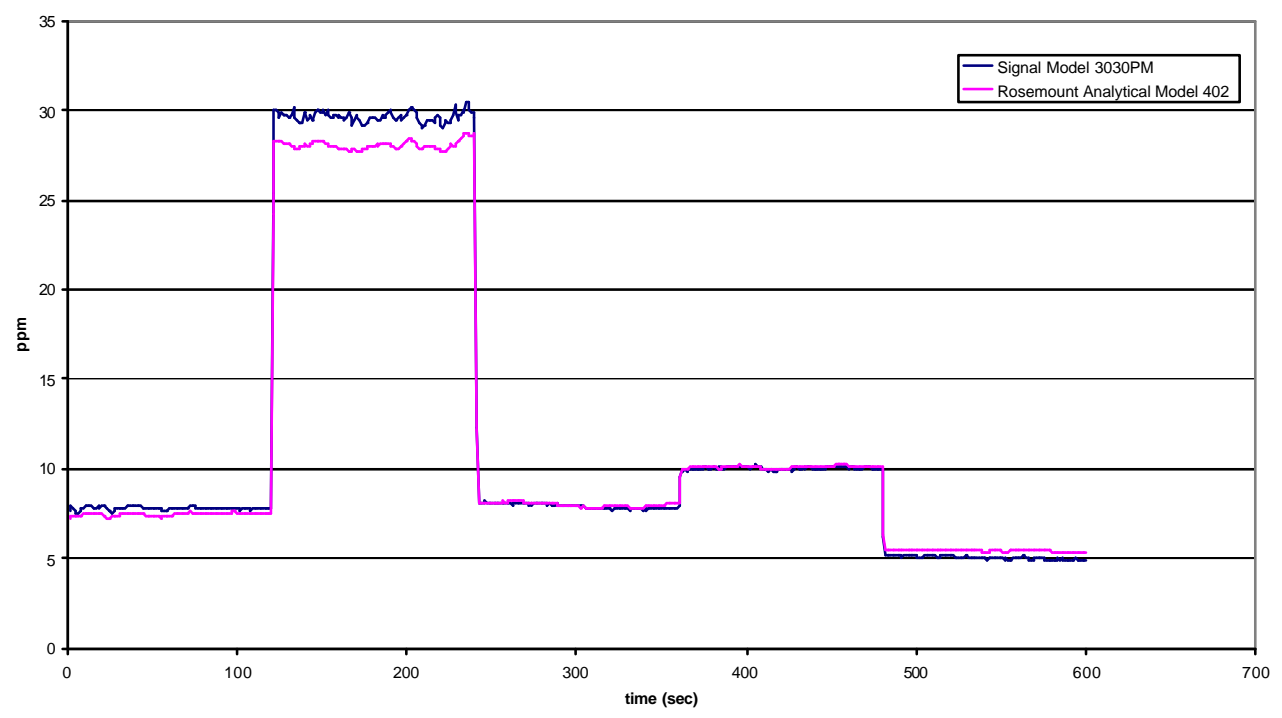

Figure 4.12 Hydrocarbon comparison of the HFID for steady state 6-mode test-1. 


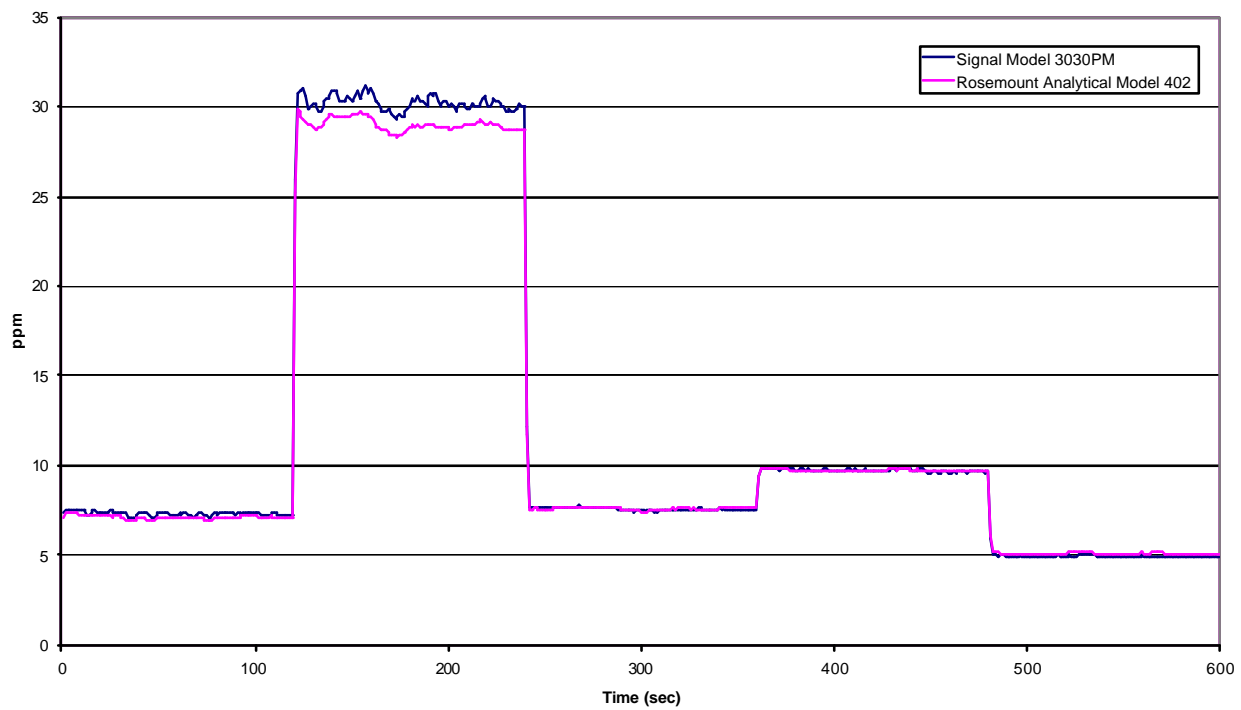

Figure 4.13 Hydrocarbon comparison of the HFID for steady state 6-mode test-2.

From Figure 4.12 and Figure 4.13, for a comparison, all the modes matched well except for the second mode. But looking at the differences between the Signal Model 3030PM and the Rosemount Analytical 402 analyzers, the second mode is still within 6\% (See Appendix A for all graphs pertaining to the HFID testing).

Again regression analysis was used to relate the two analyzers. Figure 4.14 and Figure 4.15 show that the r-squared value of the regression is above 0.99 . This means that the trend line strongly represents the data. The trend line has a slope of around 0.95 . This means that the data from the analyzers do not match exactly, but are close to the same values at each specified time. Note: the trend line is forced through the zero axes, and it is assumed that the trend is a linear trend. 


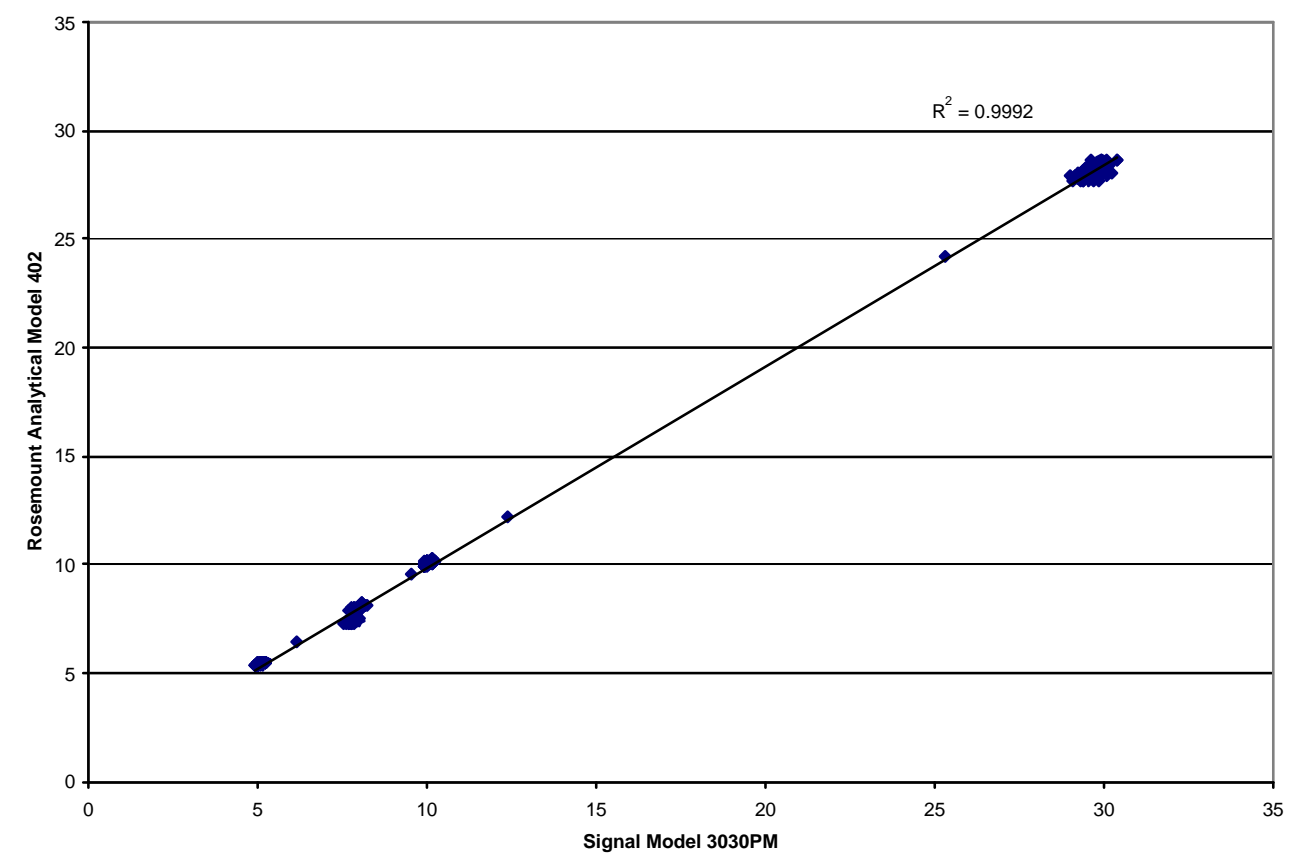

Figure 4.14 Regression analysis of the HFID for steady state 6-mode test-1.

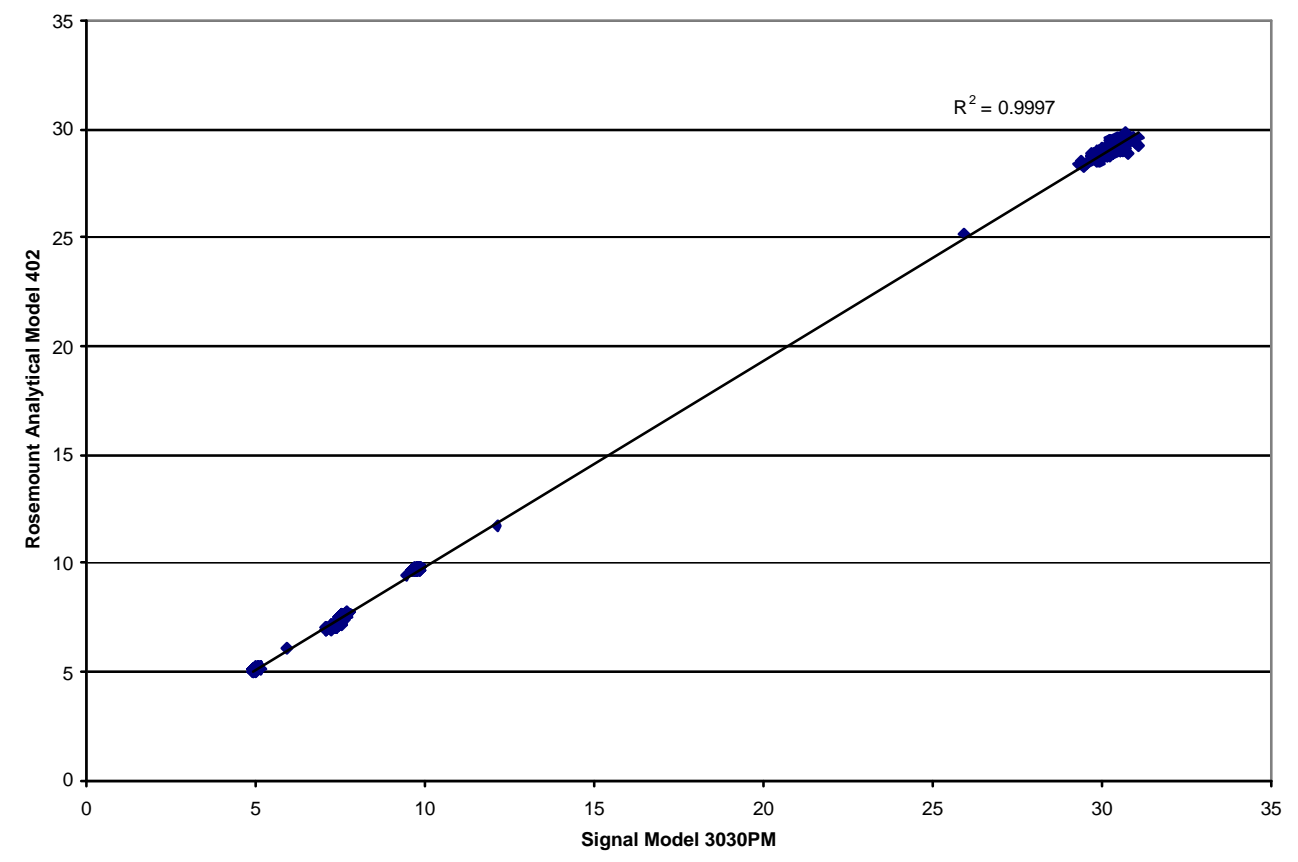

Figure 4.15 Regression analysis of the HFID for steady state 6-mode test-2. 


\subsection{V-Cone Flow Measurement Validation Testing}

MEMS is currently using an Annubar ${ }^{\circledR}$ as a differential pressure flow measurement device. The Annubar ${ }^{\circledR}$ requires fully developed flow. Hence, there needs to be unobstructed pipe length upstream and downstream to ensure the flow is fully developed. The rule of thumb is to have at least ten diameters (of the pipe) upstream and downstream to ensure fully developed flow. Therefore, the size of an Annubar ${ }^{\circledR}$ based flow metering device, with a 5 inch exhaust, the unobstructed pipe needs to be about 100 inches $(2.54 \mathrm{~m})$ long. The length of the pipe then becomes a limitation for on-road emissions testing. To mount the Annubar ${ }^{\circledR}$ pipe inline with the exhaust system of the truck, the trucks exhaust stack needs to be removed and replaced with the Annubar ${ }^{\circledR}$ based flow metering section.

The V-Cone is an obstructive, differential pressure, flow rate measurement device. A conical mass located in the center of the flow profile, forces the high velocity and low velocity flow to mix, conditioning the flow. A static pressure port is located just upstream of the conical mass, and another static pressure port is located on the downstream side of the conical mass. This differential pressure is then related to the flow rate. Because the V-Cone reshapes the flow profile, the flow doesn't need to be fully developed for the V-Cone to operate, eliminating the upstream and downstream unobstructed pipe.

To validate the V-Cone as a viable means for measuring exhaust flow rates, steady state and transient tests were employed. 


\subsubsection{Preliminary Tests}

Steady state (5-Mode) and transient (Dozer Cycle) tests, developed by Gautam, et al., 2002 [15], were conducted to evaluate the V-Cone as a flow rate measurement device and compare its performance with the Annubar. Both the Annubar ${ }^{\circledR}$ and the V-Cone were in-line in the exhaust system. The evaluation was conducted on a DDC series 60 engine in WVU's EERL test cell. The steady-state and transient cycles are presented below. The comparison of the Annubar ${ }^{\circledR}$ and V-Cone flow measurements showed that the V-Cone differential pressure transducer over ranged in every test, the 2 steady states and 2 transients. Figure 4.16 and Figure 4.18 that show flow data support the fact that the V-Cone pressure transducer over ranged.

\subsubsection{Steady-State V-Cone Tests}

The first series of tests were intended to determine if the V-Cone was even a viable device of hot exhaust flow applications. Not too much attention was devoted to proper sizing of pressure transducers at this point. Several of the 6-mode steady-state cycles were run to compare the V-Cone and the Annubar ${ }^{\circledR}$ as flow meters. The differential pressure transducer for the V-Cone was a 23 inWC diaphragm. But, the differential pressures that were achieved during the test cycles were greater than 23 inWC. The data is presented to show that through inspection of the flow, the DP was found to be greater than the capabilities of the transducer. 


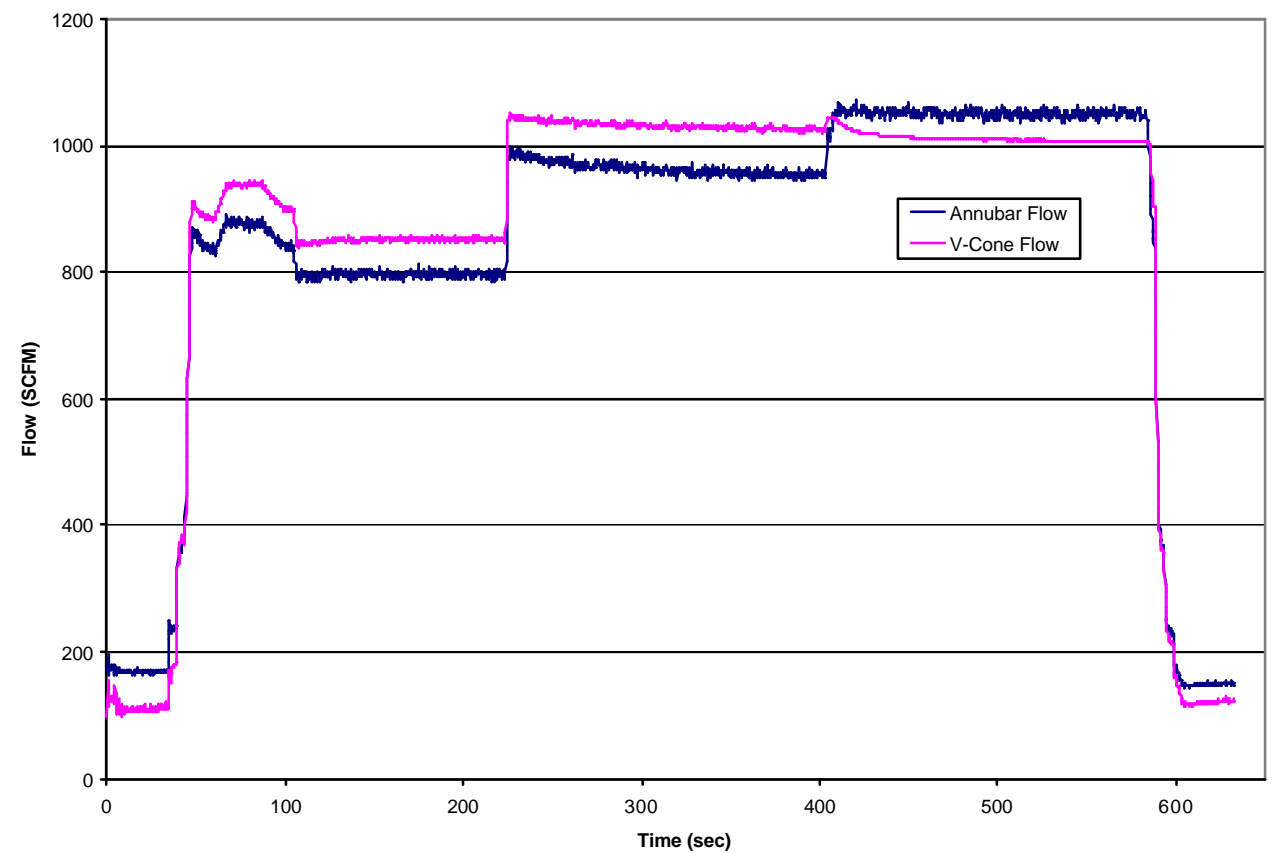

Figure 4.16 Flow comparison of the V-Cone and Annubar ${ }^{\circledR}$ for steady state test-01.

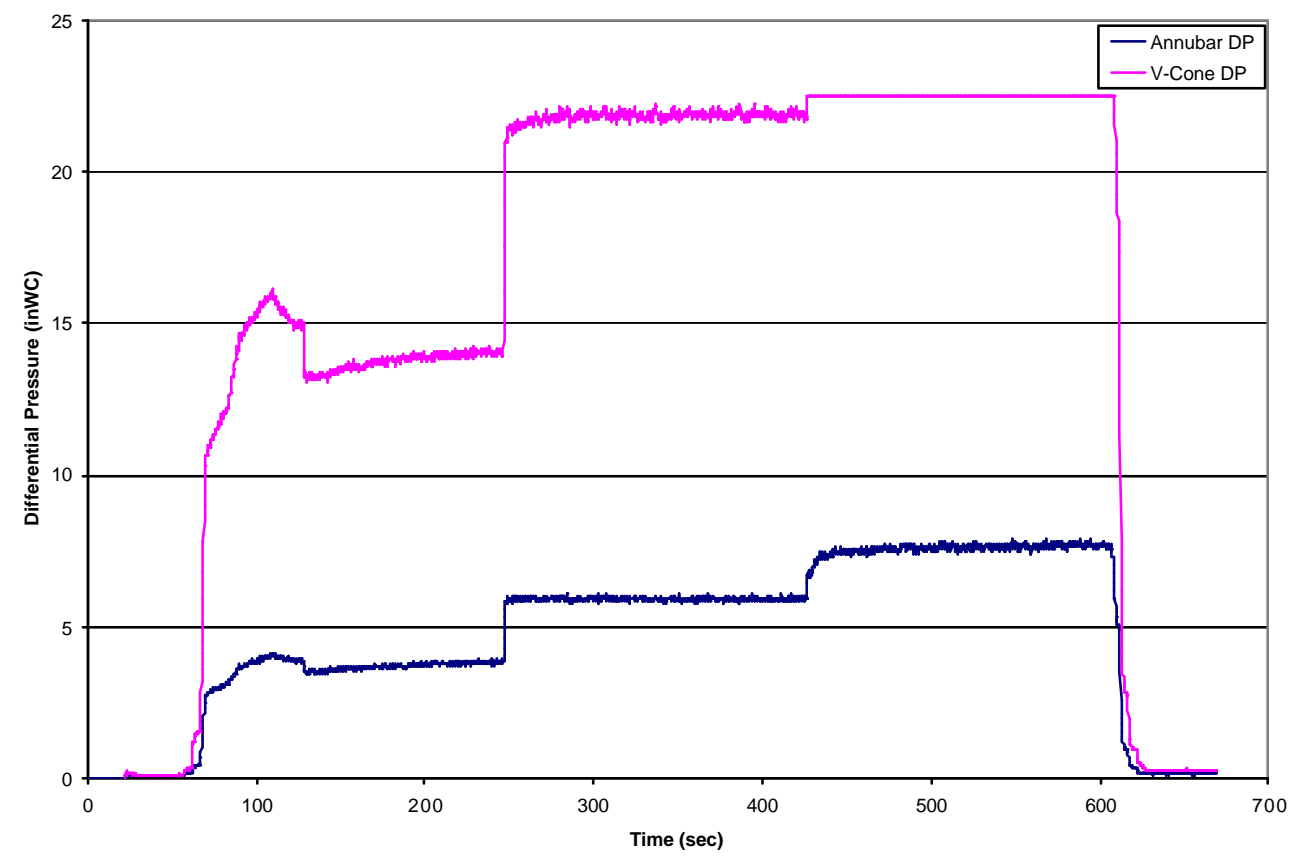

Figure 4.17 Differential pressures for the V-Cone and Annubar ${ }^{\circledR}$ for steady state test-01. 


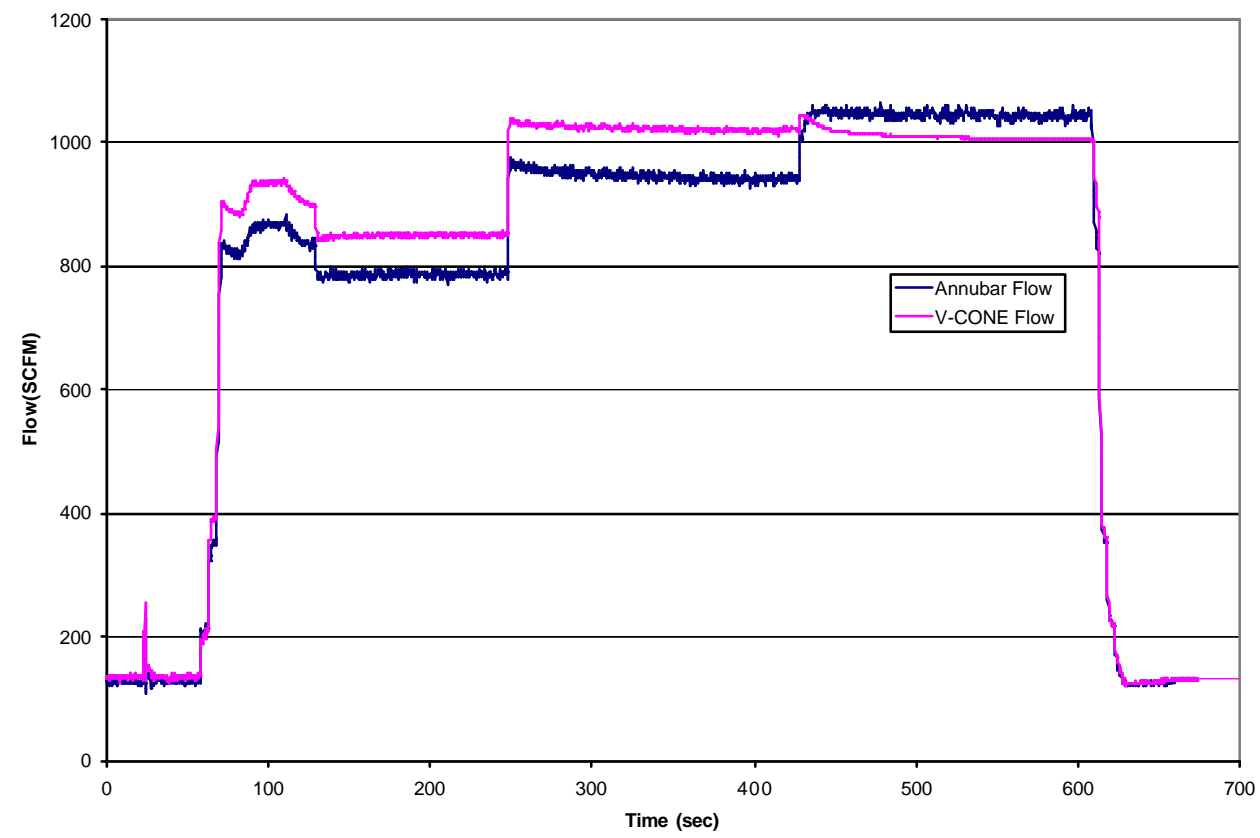

\section{Figure 4.18 Flow comparison between the V-Cone and Annubar ${ }^{\circledR}$ for steady state test-02}

Figure 4.16 compares the flow rates measured with the V-Cone and the Annubar $^{\circledR}$. Figure 4.17 shows a comparison of the differential pressures for the same steady state test. To show that this was not a one test event, Figure 4.18 shows results from another steady state test. Ano ther reason for further testing is the fact that the VCone shows an offset from the Annubar ${ }^{\circledR}$. These tests showed that the V-Cone could certainly serve as a viable means of measuring exhaust flow rates.

\subsubsection{Transient Tests: Dozer Cycle}

The steady state comparison was presented earlier in this report, while the preliminary transient tests are presented below.

The dozer transient test cycle was used to test the V-Cone with the Annubar ${ }^{\circledR}$ for the transient tests. Similar to steady state tests, the DP transducer on the V-Cone over 
ranged during peak flows. Figure 4.19 shows a flow rate comparison between the Annubar $^{\circledR}$ and V-Cone for one of the transient tests. At peak flow, the V-Cone flow exhibited a different trend than the Annubar ${ }^{\circledR}$ flow. Figure 4.20 shows the DP for the VCone and Annubar ${ }^{\circledR}$ for the transient test. It is evident that the DP transducer over ranged at the highest exhaust flow rates.

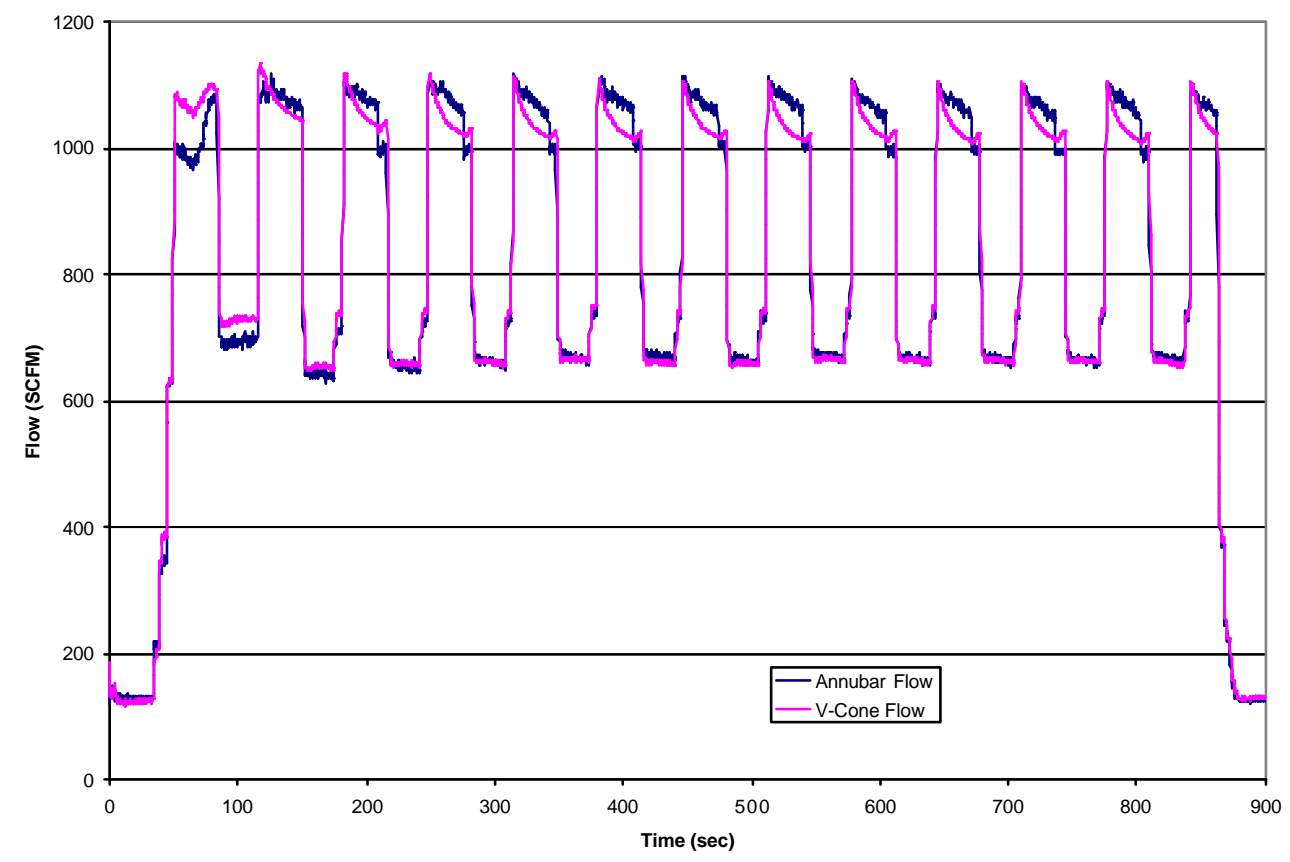

Figure 4.19 Flow comparison between the V-Cone and Annubar ${ }^{\circledR}$ for transient test of the dozer cycle. 


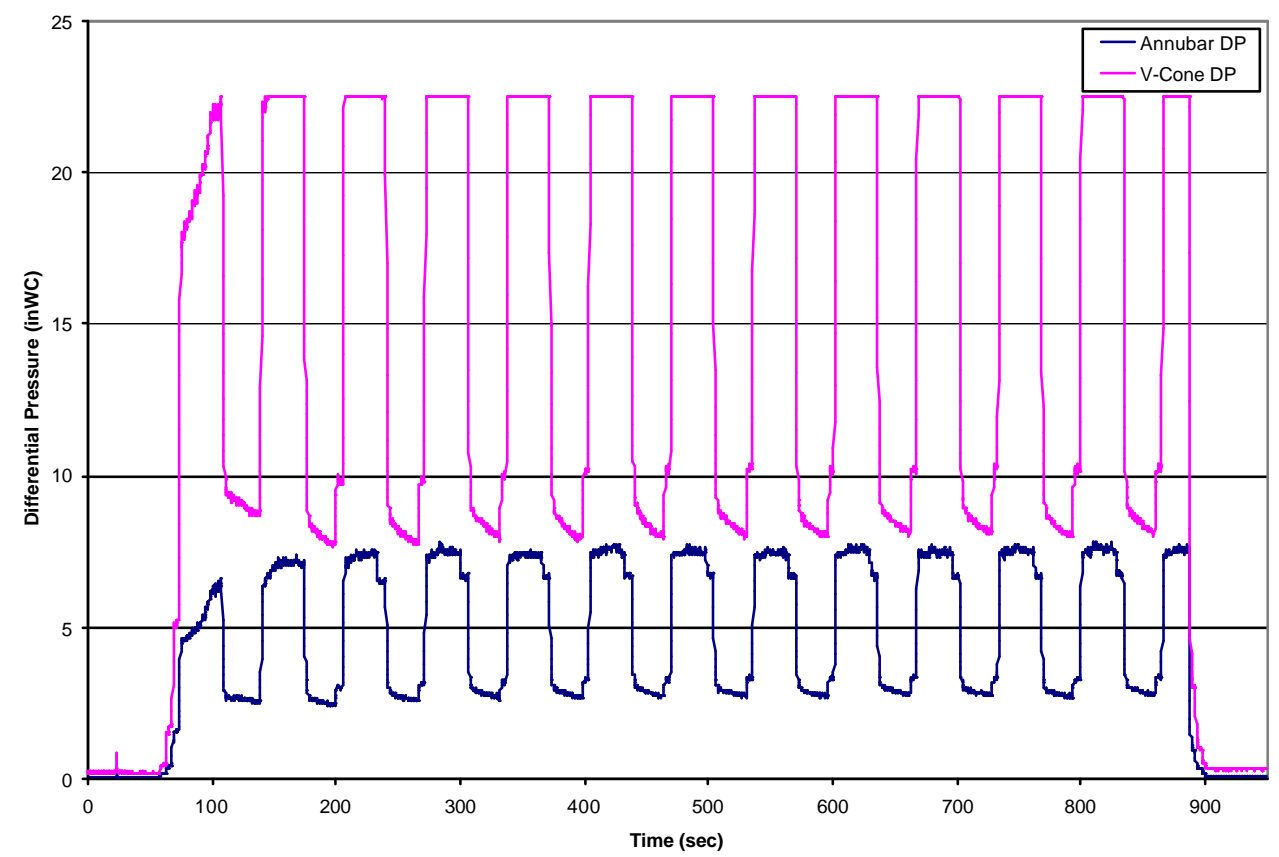

\section{Figure 4.20 Differential pressures for the V-Cone and Annubar ${ }^{\circledR}$ transducers for the transient test of the dozer cycle.}

Every cycle that was run to evaluate the V-Cone as an alternative to the Annubar ${ }^{\circledR}$ as a flow rate measurement device had the V-Cone DP transducer over ranging; more importantly, these preliminary tests showed that the V-Cone could be readily employed for measuring exhaust flow rates.

\subsubsection{Testing Conducted September 2002}

Based upon the results from the preliminary tests, the pressure transducers were properly sized, the data reduction software was rectified and another series of tests was conducted in order to compare the V-Cone and the Annubar ${ }^{\circledR}$. Transient and steady state test cycles were run on a Volvo VED123-425 engine. 
The comparison of the V-Cone and Annubar ${ }^{\circledR}$ flow devices was piggy-backed onto another study that was being conducted in the laboratory test cell. The transient test cycle used in this series of tests was recreated from an actual on-road operation of a class8 tractor. Specifically, the transient cycle was developed from the first leg of the Washington, PA route that was developed for the consent decrees work that is being conducted at WVU. This cycle was called the PA1 cycle. Five tests were conducted using this PA1 cycle. A steady state cycle was also developed specifically for the comparison testing. It included 9 modes with an idle at the beginning and the end of the cycle. Each mode was approximately 2 minutes in length. The modes varied in the load and speed of the engine. Table 4.1 shows the load and speed of each mode.

Table 4.1 Speed and load set points for the steady state test cycle.

\begin{tabular}{|r||c||c||}
\hline Mode & Speed (RPM) & Load (ft-lbs) \\
\hline \hline Idle & 600 & 5 \\
\hline \hline Mode 1 & 1110 & $\max$ \\
\hline \hline Mode 2 & 1700 & $\max$ \\
\hline \hline Mode 3 & 1800 & $\max$ \\
\hline \hline Mode 4 5 & 1800 & 450 \\
\hline \hline Mode 6 & 1700 & 450 \\
\hline \hline Mode 7 & 1200 & 450 \\
\hline \hline Mode 8 & 800 & 150 \\
\hline \hline Mode 9 & 1700 & $\max$ \\
\hline \hline Idle & 600 & 5 \\
\hline \hline
\end{tabular}




\subsubsection{Flow Rate Measurements}

Three steady state tests and five transient test cycles were run for the instrument evaluation. Calibrations, the zeroing and spanning of the analyzers, were conducted prior to each test. The setup for these tests included an Annubar ${ }^{\circledR}$ flow rate measure device and a V-Cone ${ }^{\circledR}$ flow rate measurement device in-line with the exhaust system. Differential (DP) and absolute (AP) pressure transducers were connected to each flow rate measurement device, as well as temperature measurements. Both of the MEMS (the original and second generation MEMS) systems draw an exhaust sample from the exhaust stream and take emissions measurements. 


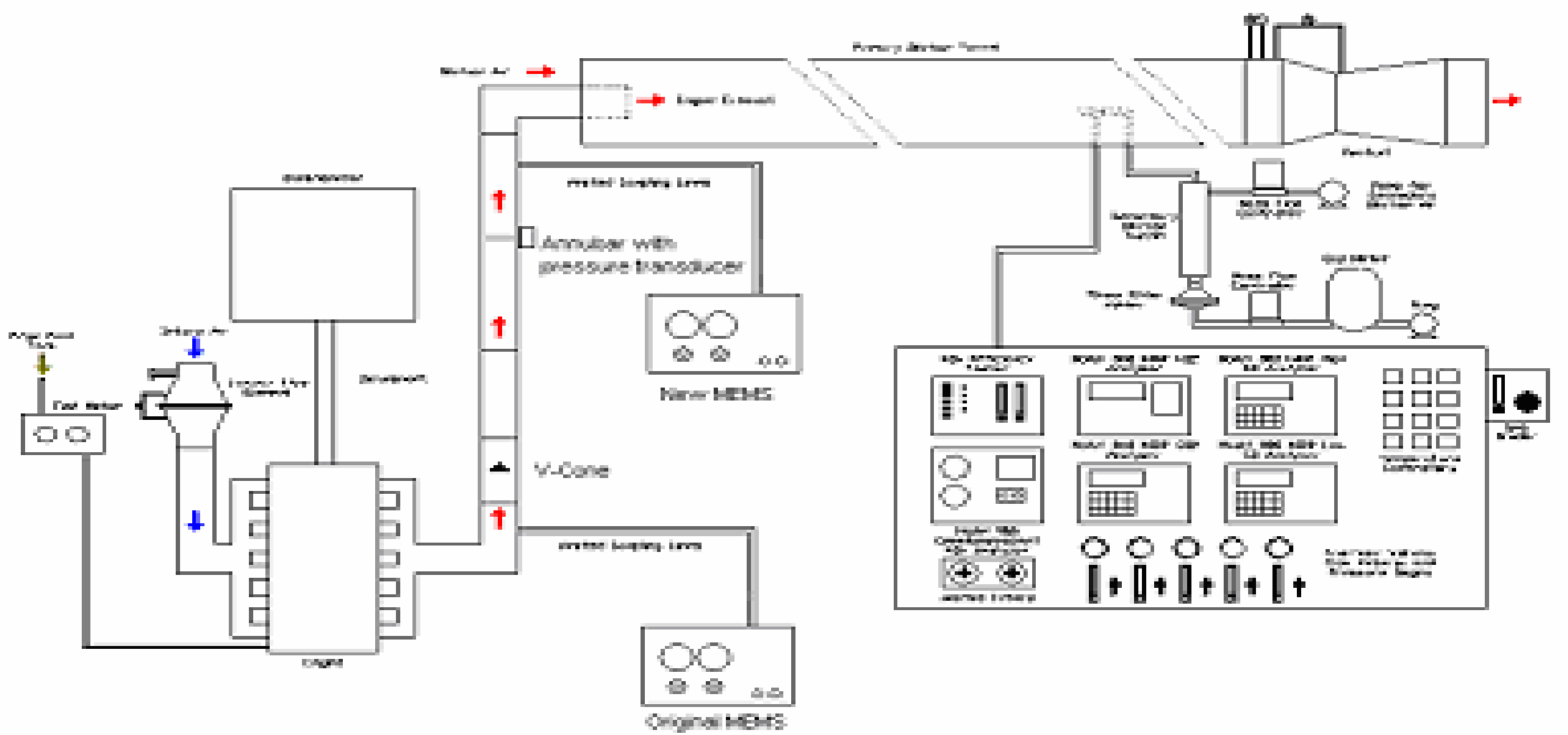

Figure 4.21 Flow schematic of the EERL test cell, with both the MEMS systems and flow meters in-line with the exhaust. 
The first generation MEMS system was used to record the V-Cone data, which includes DP, AP, and temperature of the exhaust stream at the V-Cone, and to take emissions data $\left(\mathrm{NO}_{\mathrm{X}}\right.$ and $\left.\mathrm{CO}_{2}\right)$. The emissions data that the first generation MEMS recorded is not included in this report. The second generation MEMS system was also sampling from the exhaust line and recording emissions data. The emissions data from the second generation MEMS is used in this report to generate the emissions mass rate values. WVU's EERL test cell was also used to measure emissions from the Volvo VED123-425 engine.

Using the test cells resident data reduction program and the data reduction program for the second generation MEMS system, the concentrations obtained from the test cell and the second generation MEMS were reduced to mass rate values. The emissions reduction for the V-Cone was calculated manually. Emissions concentrations were taken from the second generation MEMS system, while the volume flow data was taken from the V-Cone measurements. The standard conditions that were used for this testing were $29.92 \mathrm{inHg}(101.3 \mathrm{kPa})$ and $20^{\circ} \mathrm{C}$. The flow rates were standardized using the previous conditions, as well as ensuring all emissions values are on a wet concentration basis. The $\mathrm{NO}_{\mathrm{X}}$ concentrations, from which the emissions mass rates are calculated, are wet concentrations. The $\mathrm{CO}_{2}$ concentrations are dry readings because the Horiba BE-140 uses NDIR to measure the concentrations. MEMS sample conditioning system includes a dryer to remove the moisture from the sample. Therefore, the sample is dried prior to the introduction to the BE-140. The test cell also reads a dry $\mathrm{CO}_{2}$ concentration. To make appropriate comparisons, each emissions rate must be either wet or dry. Therefore, all the $\mathrm{NO}_{\mathrm{X}}$ measurements and readings are wet, and all the $\mathrm{CO}_{2}$ 
concentrations measurement were converted back to wet. Using Equation 11 and Equation 12, which can be also found in the CFR Part 40 Part 89 [10], the mass rate emissions for $\mathrm{NO}_{\mathrm{X}}$ and $\mathrm{CO}_{2}$ were calculated from the concentration values.

\section{Equation 11}

mass rate NO $_{X}=\frac{\omega_{\mathrm{NO}_{X}} * \text { Conc. in ppm } \text { plow }_{S C F M} * 0.02832}{60}$

\section{Equation 12}

mass rate $\mathrm{CO}_{2}=\frac{\omega_{\mathrm{CO}_{2}} * \text { Conc. in } \% * \text { Flow }_{S \mathrm{SFM}} * 0.02832}{60}$

$\omega_{\mathrm{NO}_{\mathrm{X}}}$ and $\omega_{\mathrm{CO}_{2}}$ are values that convert the concentrations into equivalents at the specified standard conditions. They are calculated by Equation 13 and Equation 14, while 0.02832 is the conversion from cubic feet to cubit meters, and division by 60 is the conversion from per minute rates to per second rates.

\section{Equation 13}

$$
\omega_{N O_{X}}=\frac{M}{M_{V}} \times \frac{T_{O}}{T_{O}+T} \times \frac{P}{P_{O}} \times \frac{\operatorname{Conc}(p p m)}{10^{6}}
$$

\section{Equation 14}

$$
\omega_{\mathrm{CO}_{2}}=\frac{M}{M_{V}} \times \frac{T_{O}}{T_{O}+T} \times \frac{P}{P_{O}} \times \frac{\operatorname{Conc}(\%)}{10^{4}}
$$


Table 4.2 Nomenclature for dry to wet conversion.

\begin{tabular}{||c||c||}
\hline \hline Symbol & Physical Meaning \\
\hline \hline & $\begin{array}{c}\text { Molecular number } \\
\left(\mathrm{NO}_{\mathrm{X}}=46 \mathrm{~g} / \mathrm{mol}\right) \\
\left(\mathrm{CO}_{2}=44 \mathrm{~g} / \mathrm{mol}\right)\end{array}$ \\
\hline \hline $\mathrm{M}_{\mathrm{V}}$ & Molecular Volume $\left(22.414 \times 10^{-3}\right)$ \\
\hline \hline $\mathrm{T}_{\mathrm{O}}$ & $273.15^{\circ} \mathrm{K}$ \\
\hline \hline $\mathrm{T}$ & $20^{\circ} \mathrm{C}$ \\
\hline \hline $\mathrm{P}$ & $101.3 \mathrm{kPa}$ \\
\hline \hline $\mathrm{P}_{\mathrm{O}}$ & $101.3 \mathrm{kPa}$ \\
\hline
\end{tabular}

A dry to wet conversion for $\mathrm{CO}_{2}$ is calculated by using Equation 15

\section{Equation 15}

$$
C O_{2 w e t}=\frac{C O_{2_{d r y}}}{1+\left(\frac{C O_{2 d r y} * \frac{H: C}{2}}{100}\right)}
$$

The concentration values recorded are on a dry basis. Therefore, all that is needed is the hydrogen to carbon ration $(\mathrm{H}: \mathrm{C})$, which is 1.8 for diesels. The second generation MEMS and the test cell concentrations are then converted from dry to wet, and Equation 12 and Equation 14 can be used to calculate the mass emissions rates for $\mathrm{CO}_{2}$.

Note: The emissions rate values can now be directly compared and investigated, since all the values are at the standard conditions of $29.92 \mathrm{inHg}(101.3 \mathrm{kPa})$ pressure, $20^{\circ} \mathrm{C}$, and are a wet concentration basis. 


\section{Flow Data}

The preliminary testing showed a flow rate offset that was similar to that observed for the more extensive follow-up testing of the V-Cone. The V-Cone generally measured higher flow rates than the Annubar ${ }^{\circledR}$. Of particular interest was the investigation into identifying the shift. For these tests, the Annubar ${ }^{\circledR}$ values are considered "true" values, because the Annubar ${ }^{\circledR}$ is currently used in MEMS, and the V-Cone is being investigated for a viable option for exhaust flow rate measurement.

The flow rate comparison between the V-Cone and Annubar ${ }^{\circledR}$ flow rate instrument is shown in the figures below. In this section, one test will be discussed, unless there are points that need to be made by using additional graphs; the graphs of the remaining tests are presented in Appendix B. Figure 4.22 shows the flow rate comparison for the transient tests and Figure 4.23 shows the steady state test. 


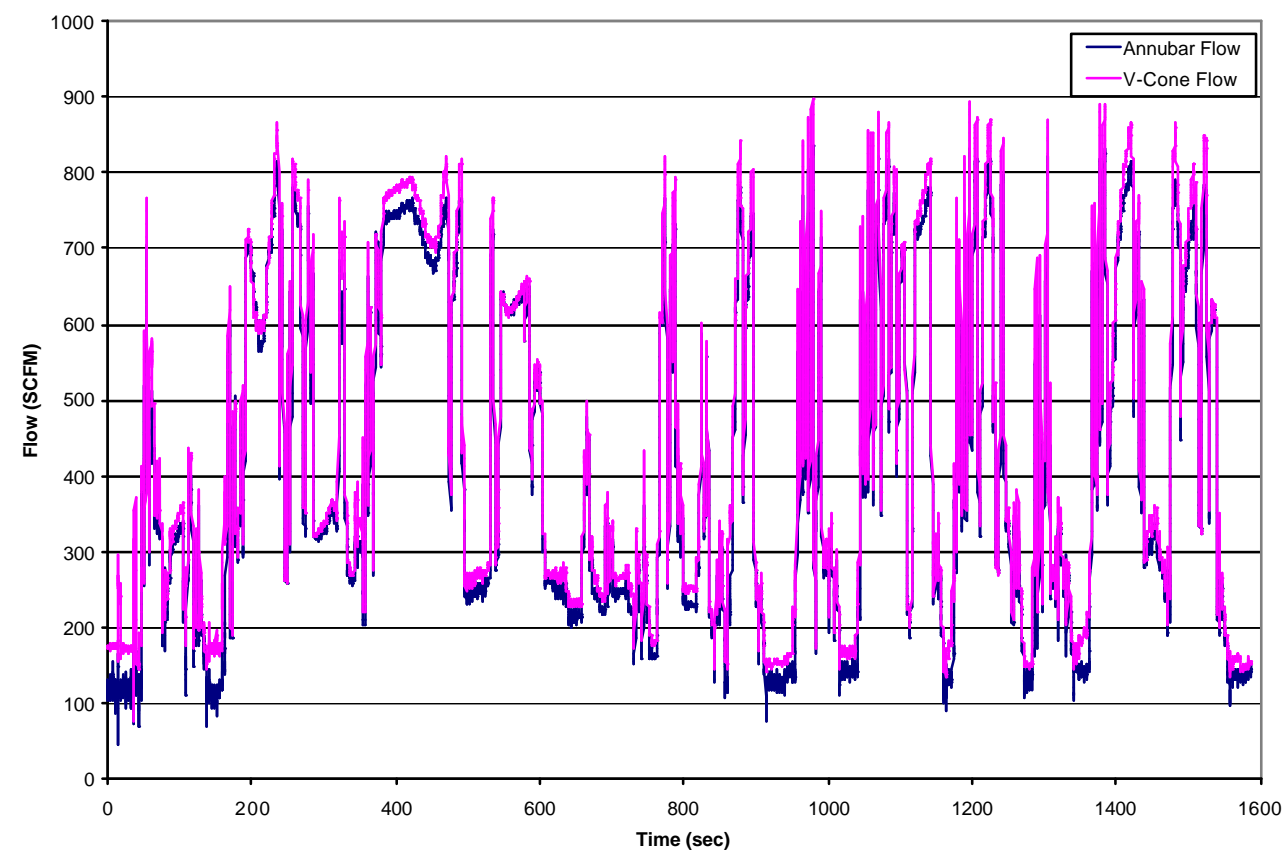

Figure 4.22 Flow rate comparison for the V-Cone andAnnubar ${ }^{\circledR}$ for transient test VolvoPA1 -01.

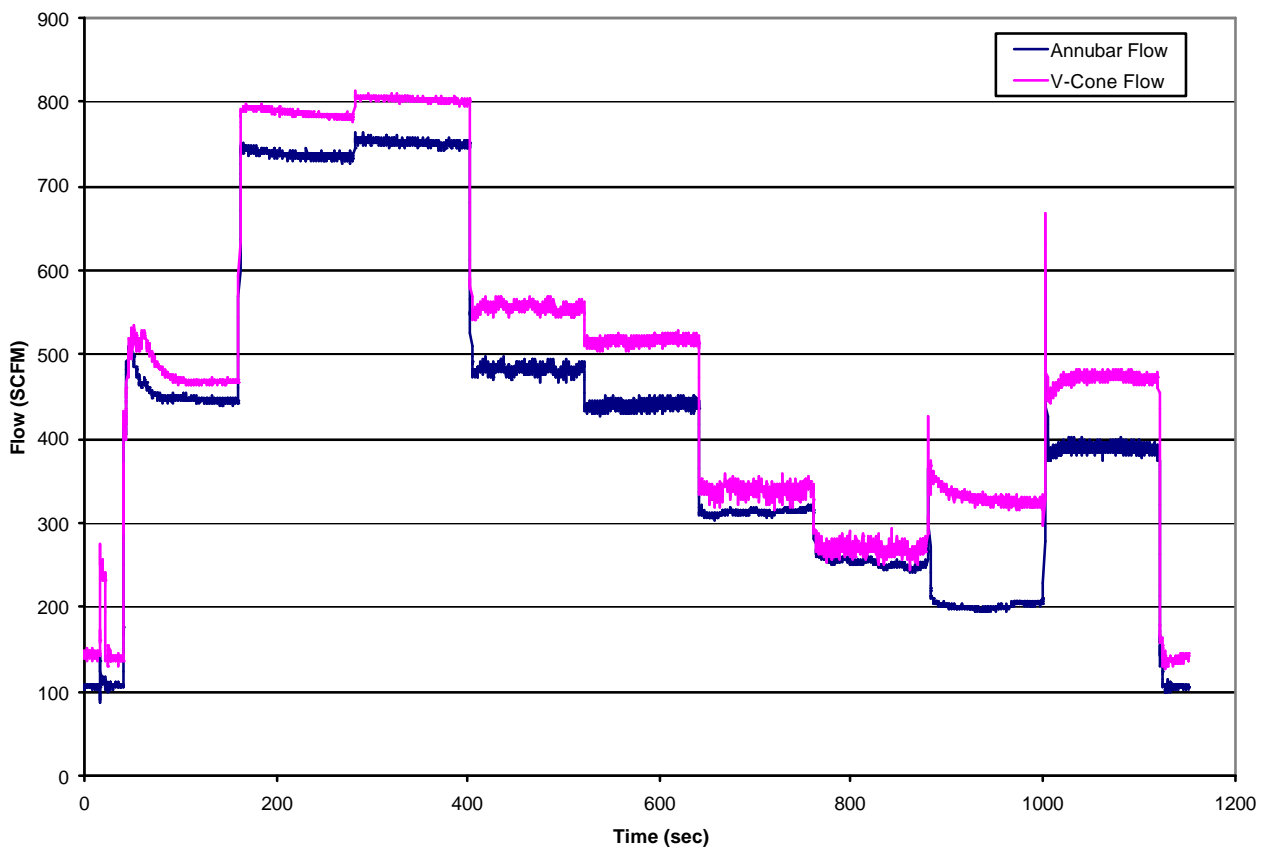

Figure 4.23 Flow rate comparison for the V-Cone and Annubar ${ }^{\circledR}$ for steady state test VolvoSS2-01. 
From evaluating the data, an offset between the flow rates of the V-Cone and Annubar $^{\circledR}$ appears to be a constant. The repeatability of the flow rates for both the transient and steady state cycles is very good. Regression analysis was used to compare the flow rates of the V-Cone and Annubar ${ }^{\circledR}$.

A linear trend line was used to generate the average slope of the data points. Therefore, the ideal slope of regression analysis is 1.00 and the closer the slope is to 1.00 , the better the relationship between the two data sets. Values of $\mathrm{R}^{2}$ were generated from regression analysis to give an indication of how close the regression analysis data points fall on the slope of the trend line. The closer the $\mathrm{R}^{2}$ value is to 1.00 ; the "tighter" the data points lay on the trend line. The lower the $\mathrm{R}^{2}$ value, the more scattered the data points.

The regression analysis for Figure 4.24, the first transient test, shows that the slope of the trend line is 1.0953 , which is close to 1.00 . The $\mathrm{R}^{2}$ value for first transient test of the Washington, PA route was 0.9862 . With the $\mathrm{R}^{2}$ value being better than 0.98 , the data showed a "tight" data set. The slope of the data showed that the V-Cone is a factor of about 1.1 off from the Annubar ${ }^{\circledR}$. The steady state tests show a relatively poorer correlation, as seen in Figure 4.25. This is due to mode- 8 of the cycle (see the flow Figure 4.23). In mode-8, the differential pressure for the V-Cone increased while the differential pressure for the Annubar ${ }^{\circledR}$ the value decreased. This gives large errors between the two instruments, and it shows on the regression analysis. A pocket of data points off of the trend line is the data points for this mode- 8 . The linear fit is influenced by this pocket of data points and the slope is observed to be higher. The pocket also affects the $\mathrm{R}^{2}$ value by decreasing the value due to the increased errors associated with this mode. 


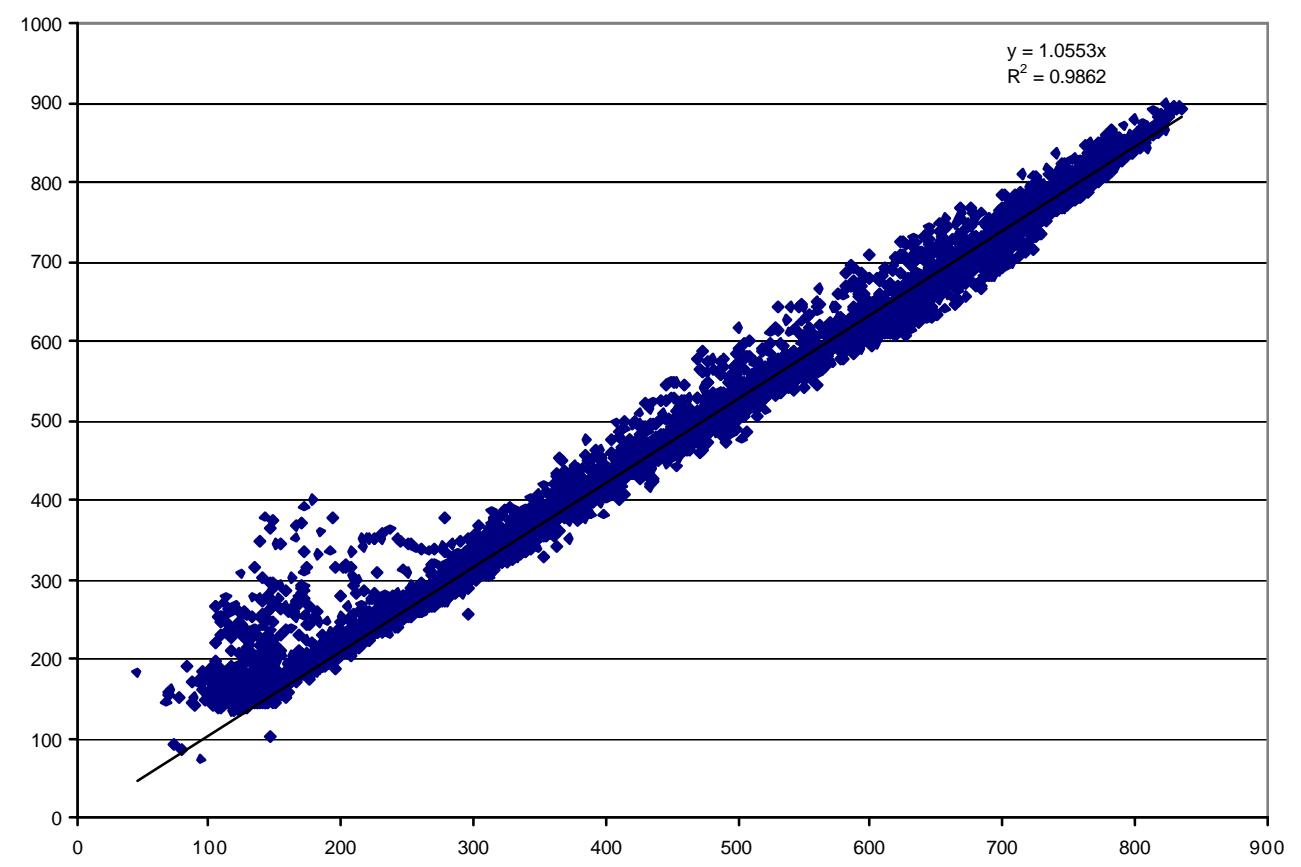

Figure 4.24 Regression analysis for flow rates between the V-Cone and Annubar ${ }^{\circledR}$ for transient test VolvoPA1-01.

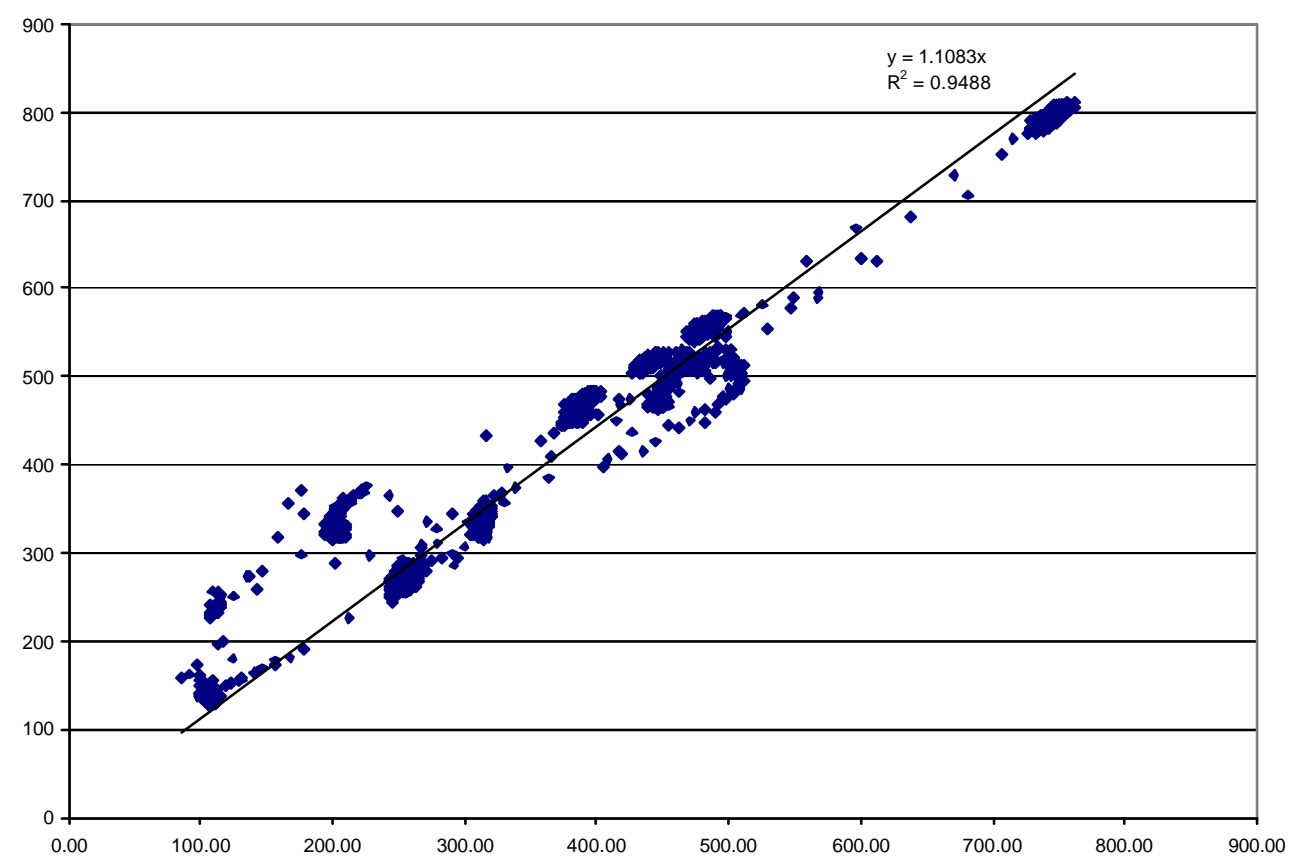

Figure 4.25 Regression analysis for flow rates between the V-Cone and Annubar ${ }^{\circledR}$ for steady state test VolvoSS2-01. 
The reasons why the V-Cone and Annubar do not agree were investigated. For all the other modes of the steady state test, the V-Cone measured higher than the Annubar ${ }^{\circledR}$, but both instruments had the same trends with just the amplitude of the V-Cone output being greater. For mode-8, the instruments flow rates go in opposite directions, V-Cone measured increased flows and the Annubar ${ }^{\circledR}$ decreased flows. Figure 4.26 shows the differential pressures for the V-Cone and Annubar ${ }^{\circledR}$ for a steady state test.

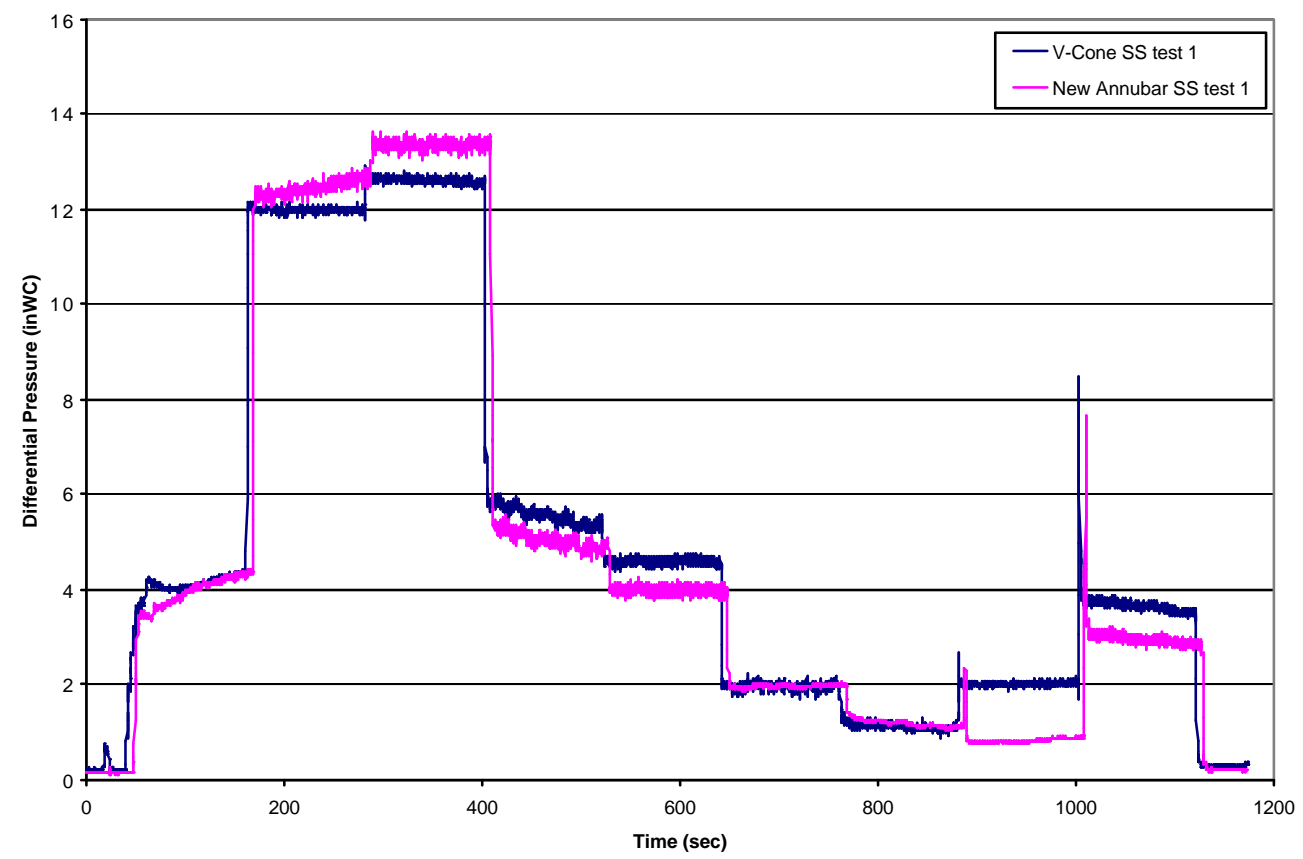

Figure 4.26 Differential pressures for the Annubar ${ }^{\circledR}$ and V-cone for steady state test VolvoSS2-01. 


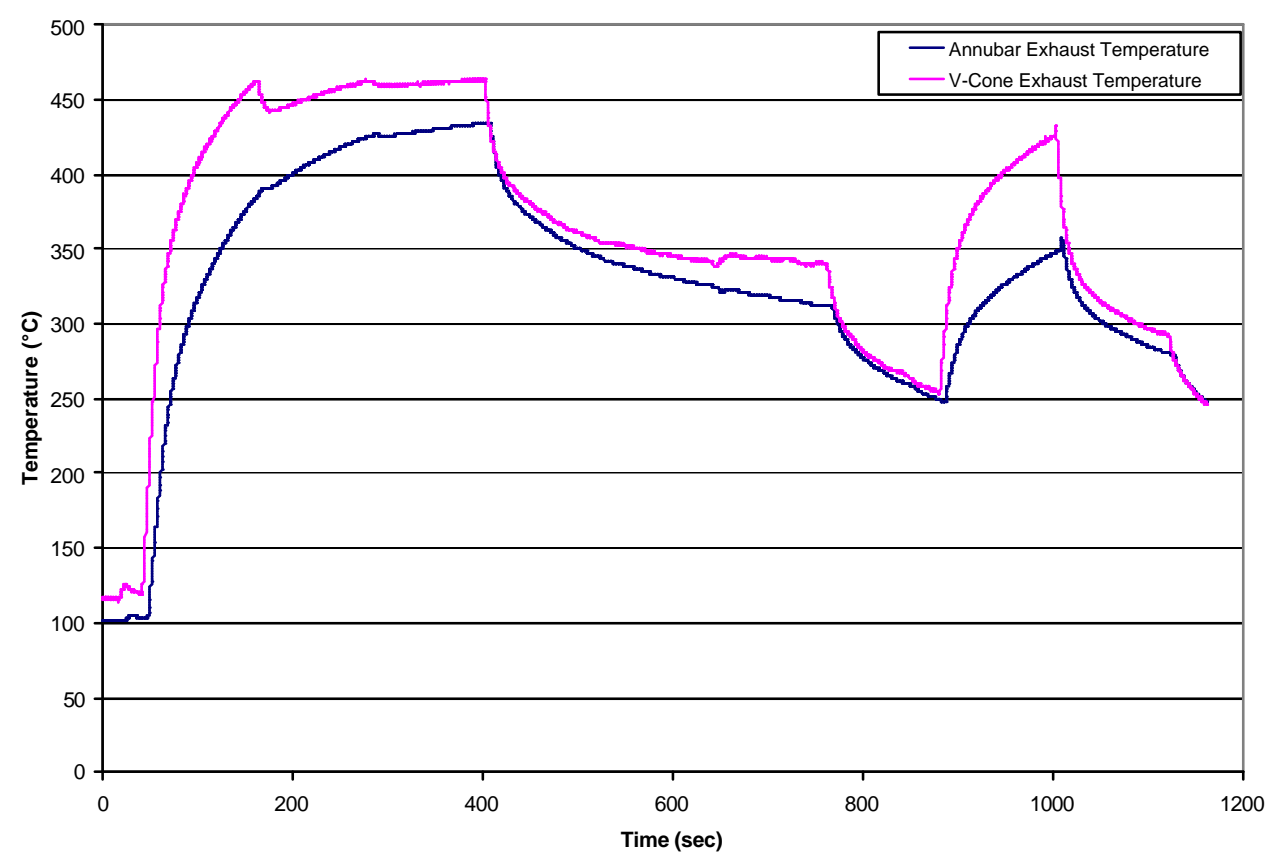

\section{Figure 4.27 Exhaust temperature compa rison at the location of the V-Cone and Annubar $^{\circledR}$ for steady state test.}

There are a couple of issues originating with the V-Cone as a possible reason for differences between the Annubar ${ }^{\circledR}$. First, there is a temperature issue. The V-Cone was considerable closer to the engine than the Annubar ${ }^{\circledR}$. Figure 4.27 shows the exhaust temperature comparison at the location of the $\mathrm{V}$-Cone, closer to the engine, and the Annubar $^{\circledR}$, further from the engine. As can be seen the temperature is much greater at the V-Cone. A note should be made that the flow rate calculations include the temperature, so temperature differences of themselves will not cause the flow rates to be different, but their may be a thermal mass issue resulting from the temperatures. Another difference between the V-Cone and Annubar ${ }^{\circledR}$ is that the pressure transducers (both the AP and DP) for the V-Cone were placed several feet from the exhaust system, and slightly higher than the exhaust level. This, in turn, caused a difference between the V-Cone and Annubar ${ }^{\circledR}$ in the dead volume for the pressure transducer lines. Note that the difference in dead 
volume is more of a concern with transient responses than steady state cycles, but the dead volumes were not optimized with each analyzer. The V-Cone had much greater dead volume in the pressure lines than the Annubar ${ }^{\circledR}$. The Annubar ${ }^{\circledR}$ had about 18 inches of ? inch stainless steel tubing, while the V-Cone had approximately 4 feet of $1 / 4$ inch tubing; therefore, the dead volume of the V-Cone system is much greater than that of the Annubar $^{\circledR}$. The V-Cone had about 12 inches of stainless steel tubing, for heat transfer purposes, and about 3 feet of Teflon tubing the rest of the way to the pressure transducers. Another problem that the V-Cone had was condensation issues. When the exhaust cooled to the dew point temperature, in the pressure lines, condensation occurred. This was not a unique problem to the V-Cone; the Annubar ${ }^{\circledR}$ had this problem as well.

The steady state tests regression slopes for all the test cycles are a little further away from the ideal of 1.00 than the transient tests, this could be indicative of the slope changes that are a result of mode 8 differences. Like the regression trend lines, the $\mathrm{R}^{2}$ values for transient test were closer to the ideal than the steady state tests, with the transient test cycles ranging from 0.91 to 0.98 (See Appendix B). A difficulty in regression analysis is the second-by-second time aligning, and any time misalignment will affect the regression analysis. Remember the dead volumes for the pressure transducers of the V-Cone and Annubar ${ }^{\circledR}$ were not equal, and therefore could have caused the time misalignment. And therefore, could be a reason for the poor slopes of the linear fit and $\mathrm{R}^{2}$ variation. With the time aligning difficult and the response of the flow rate measurement devices, there can be great differences between the flow rates on flow spikes. Figure 4.28 shows how the time alignment is important in the regression analysis. 
If, because of a time misalignment, one of the instruments begins to increase a flow rate before the other instrument, a large flow difference at a specific point can occur. The regression analysis plots this specific point, but the flow rate is different because of a possible time misalignment, and the data point is plotted off of the linear trend. When data points occur off the linear trend, the $\mathrm{R}^{2}$ value is low. Figure 4.28 shows a slight time misalignment and Figure 4.29 shows the resultant regression analysis, but Figure 4.30 shows the data that is time aligned, and Figure 4.31 shows the improvement of the regression analysis, the $\mathrm{R}^{2}$ value is higher.

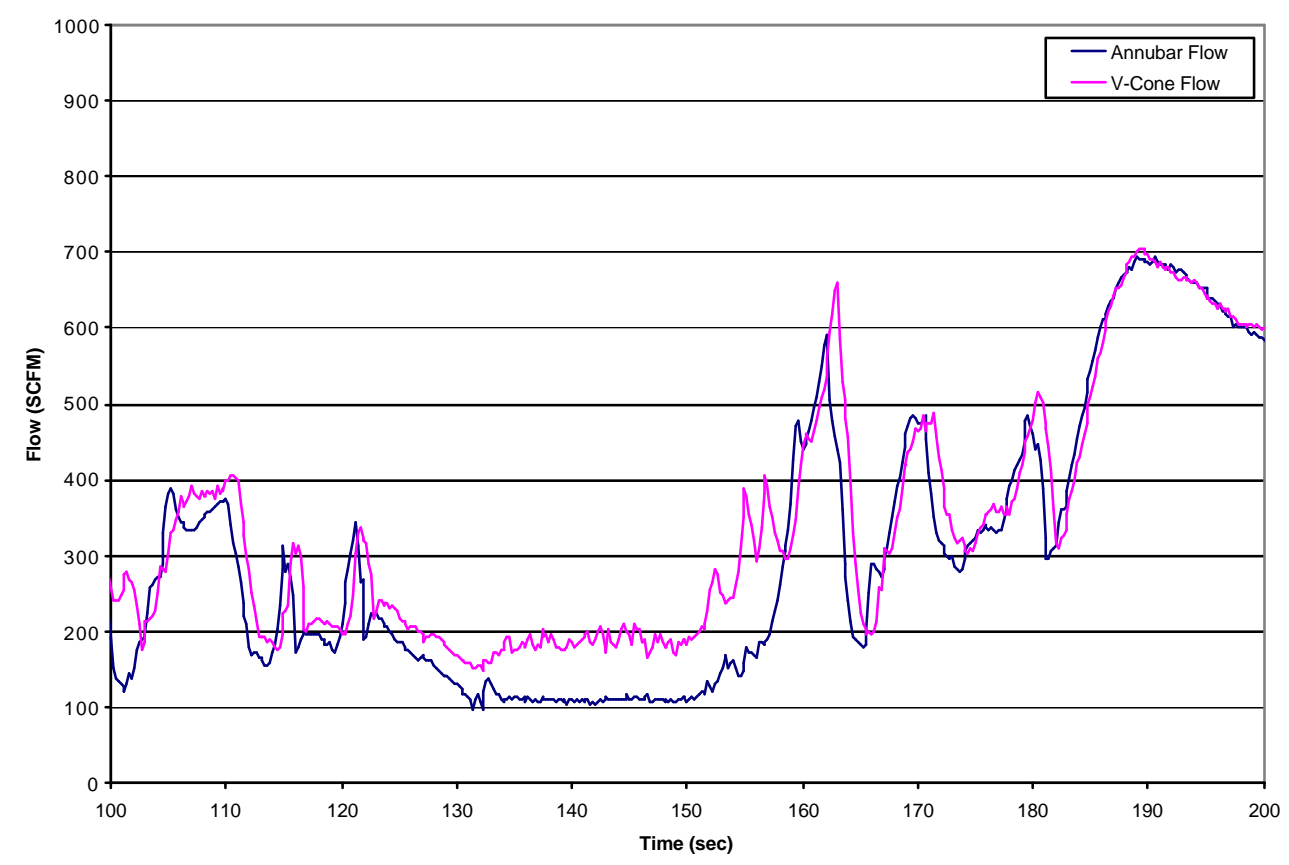

Figure 4.28 Flow rate comparison for the V-Cone and Annubar ${ }^{\circledR}$ for transient test VolvoPA1-04 before time alignment. 


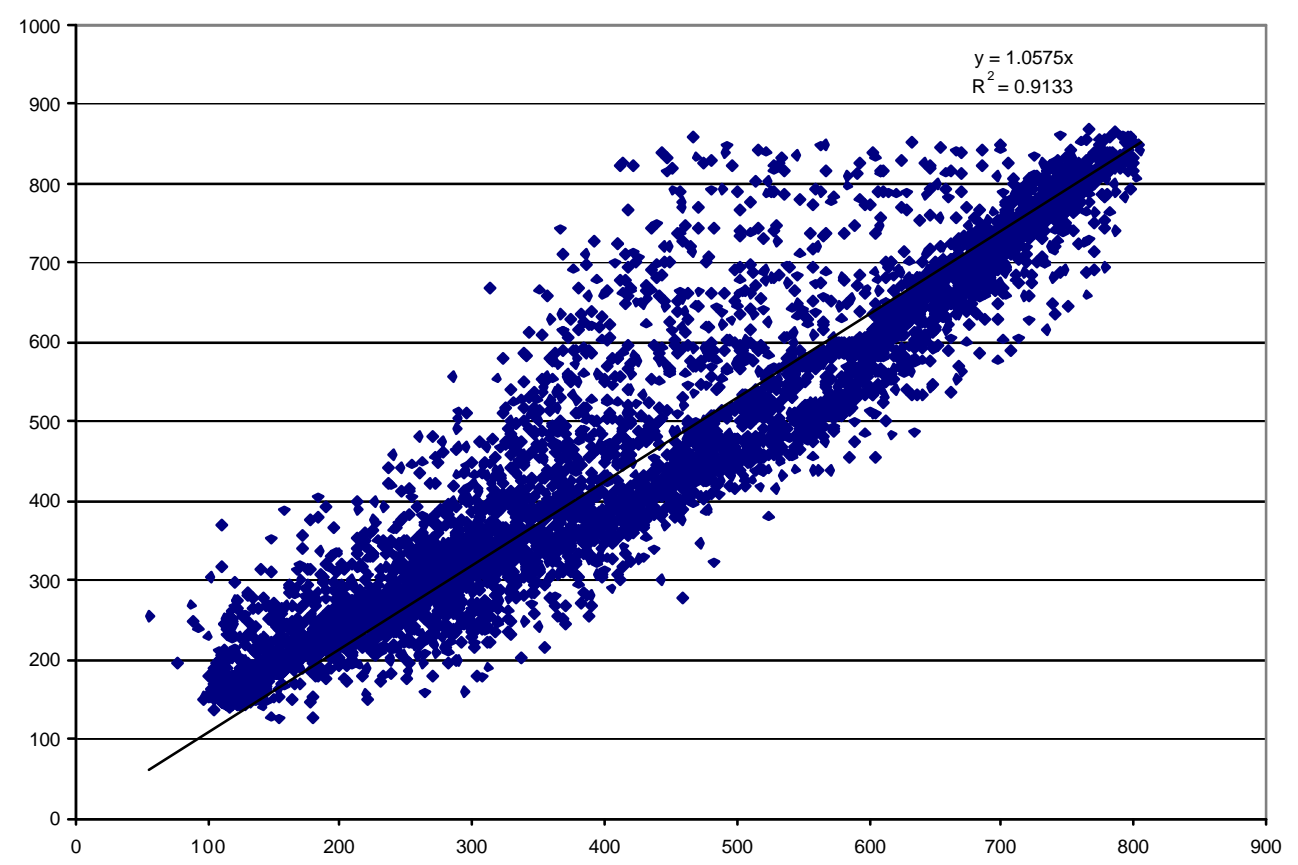

Figure 4.29 Regression analysis for transient test VolvoPA1 -04 before time alignment.

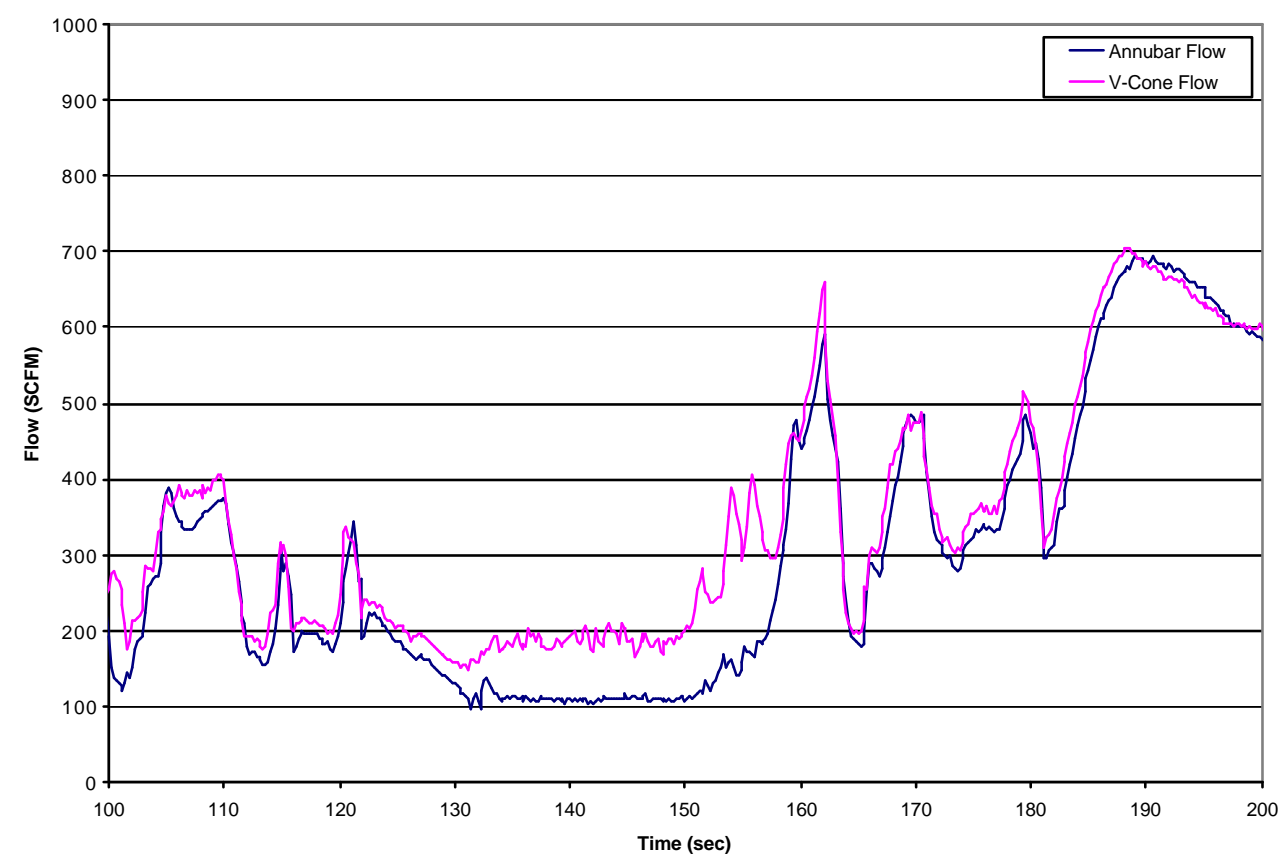

Figure 4.30 Flow rate comparison for the V-Cone and Annubar ${ }^{\circledR}$ for transient test VolvoPA1 -04 after time alignment. 


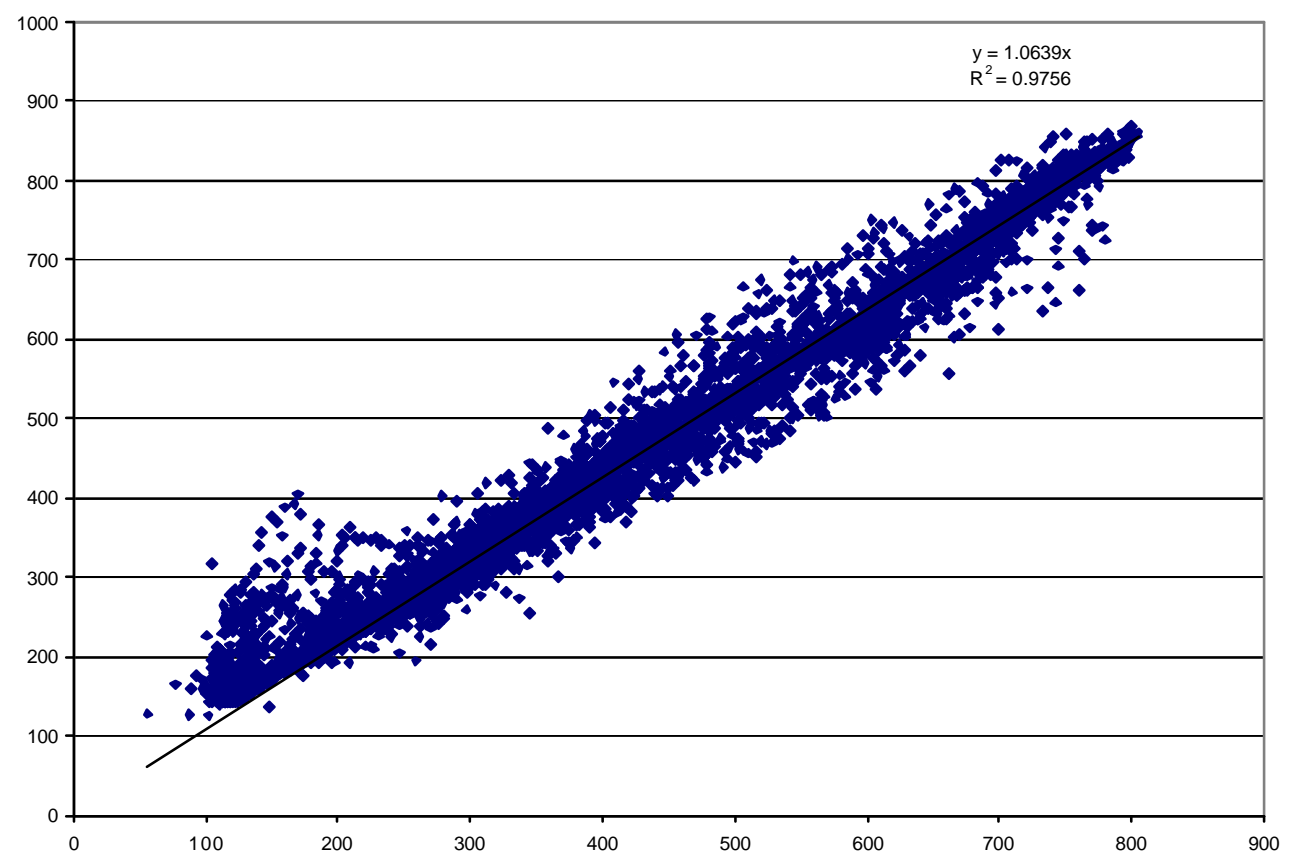

Figure 4.31 Regression analysis for transient test VolvoPA1 -04 after time alignment.

\section{Emissions Data}

The mass emissions rates of $\mathrm{NO}_{\mathrm{X}}$ and $\mathrm{CO}_{2}$ were determined during this study. The mass emissions rates were obtained by either a reduction program or by manual calculation.

Several graphs were generated to investigate the validity of the V-Cone with the Annubar $^{\circledR}$ and test cell. Mass emissions rates values for $\mathrm{NO}_{\mathrm{X}}$ for the $\mathrm{V}$-Cone reduction and second generation MEMS reduction were plotted against the Laboratory reduction mass rate values. For the $\mathrm{CO}_{2}$ mass emissions rates, the V-Cone values were plotted against the Annubar ${ }^{\circledR}$ and Laboratory values. Regression analysis was used to compare the mass emission rates of the Annubar ${ }^{\circledR}$ and V-Cone, and this done for both $\mathrm{NO}_{\mathrm{X}}$ and $\mathrm{CO}_{2}$ mass emissions rates. It should be noted, that there was a flow rate difference for 
the steady state tests at mode- 8 . Again, this mode affects the regression analysis, thus the trend line is shifted towards this pocket of data points.

\section{NO $_{\mathrm{X}}$ Data}

The $\mathrm{NO}_{\mathrm{X}}$ mass emissions rate graphs are presented below. Appendix $\mathrm{C}$ shows the Figures of all the $\mathrm{NO}_{\mathrm{X}}$ dealing the comparison of the two systems Annubar ${ }^{\circledR}$ and $\mathrm{V}$-Cone and the Laboratory.

Inspection of $\mathrm{NO}_{\mathrm{X}}$ data in Appendix $\mathrm{C}$, shows test-to-test variations in the amplitude. The first three transient tests show good repeatability, and the last two transient tests have repeatability, but there is a change around 400 seconds. Figure 4.32 and Figure 4.33 show the change in second-by-second values. Appendix $\mathrm{C}$ shows data on repeatability for all the transient tests. 


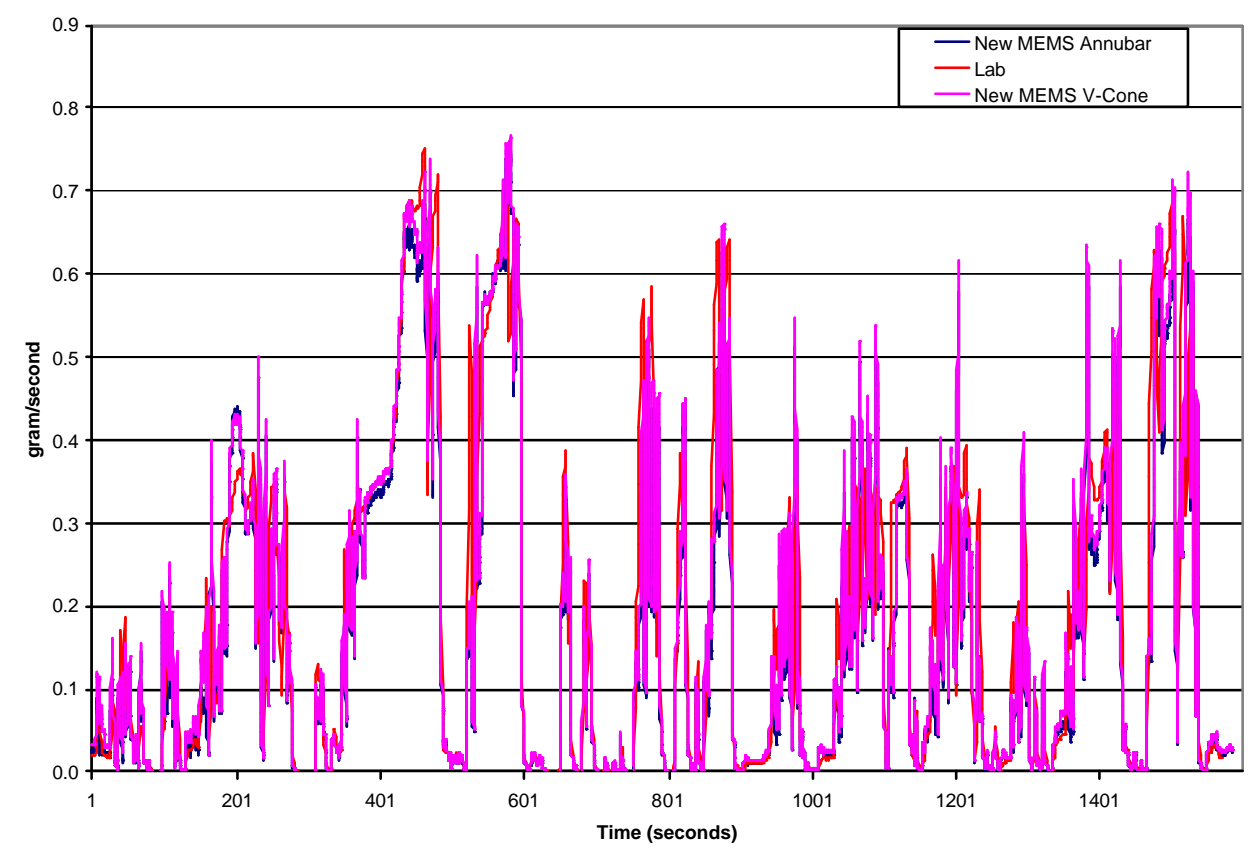

Figure 4.32 $\mathrm{NO}_{\mathrm{X}}$ mass emissions rate comparison between the V-Cone, Annubar ${ }^{\circledR}$, and Laboratory, transient test VolvoPA1-01.

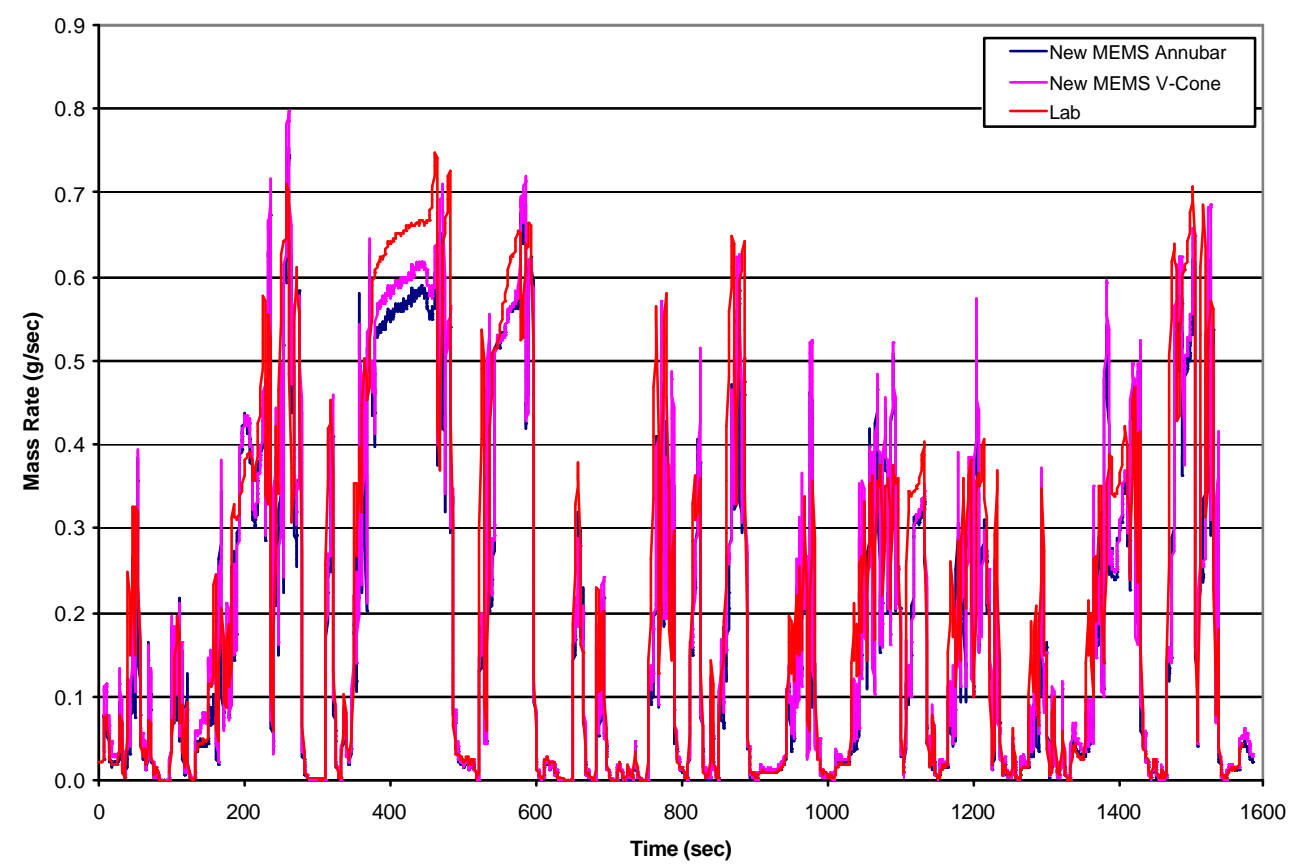

Figure 4.33 $\mathrm{NO}_{\mathrm{X}}$ mass emissions rate comparison between the V-Cone, Annubar ${ }^{\circledR}$, and Laboratory, transient test VolvoPA1-04. 


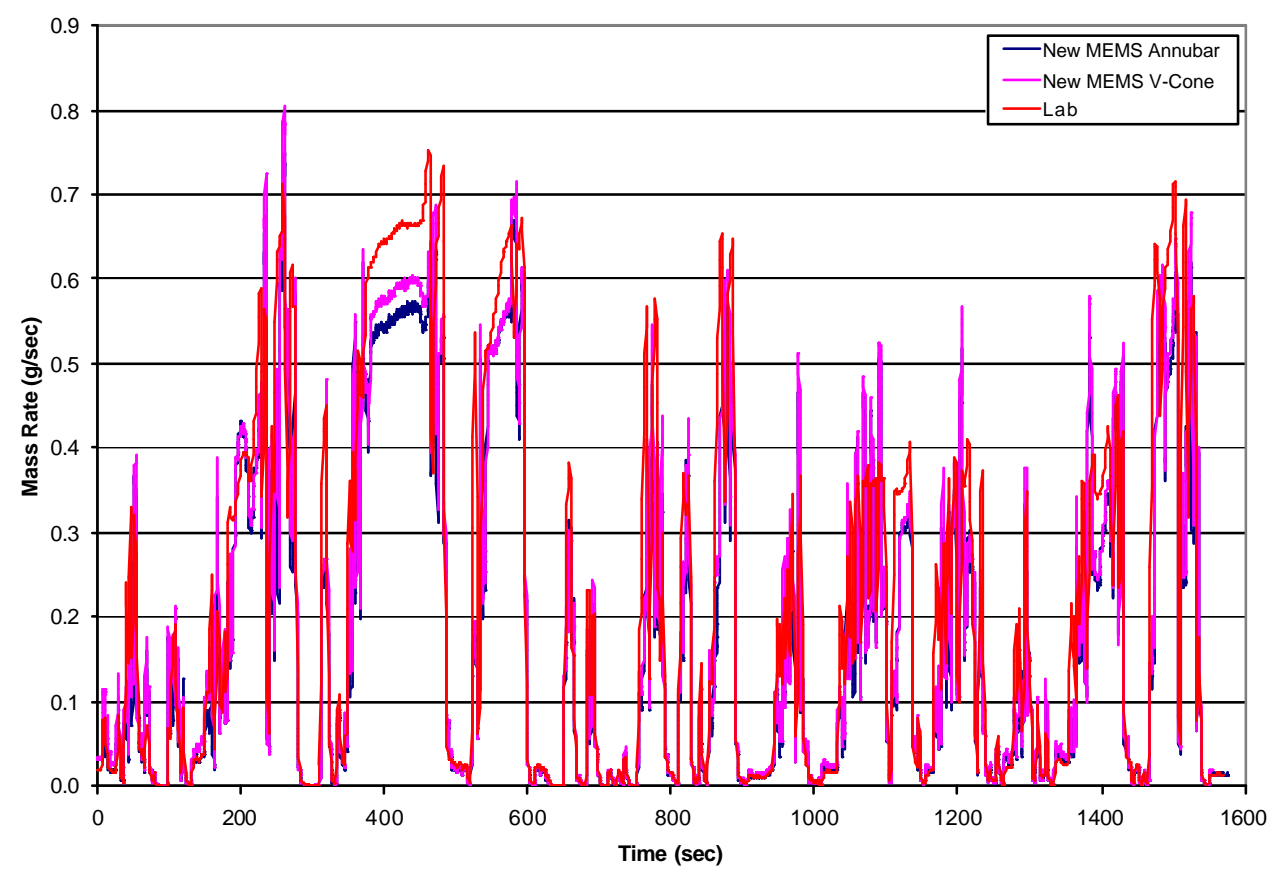

Figure 4.34 $\mathrm{NO}_{\mathrm{X}}$ mass emissions rate comparison between the V-Cone, Annubar ${ }^{\circledR}$, and Laboratory, transient test VolvoPA1-05.

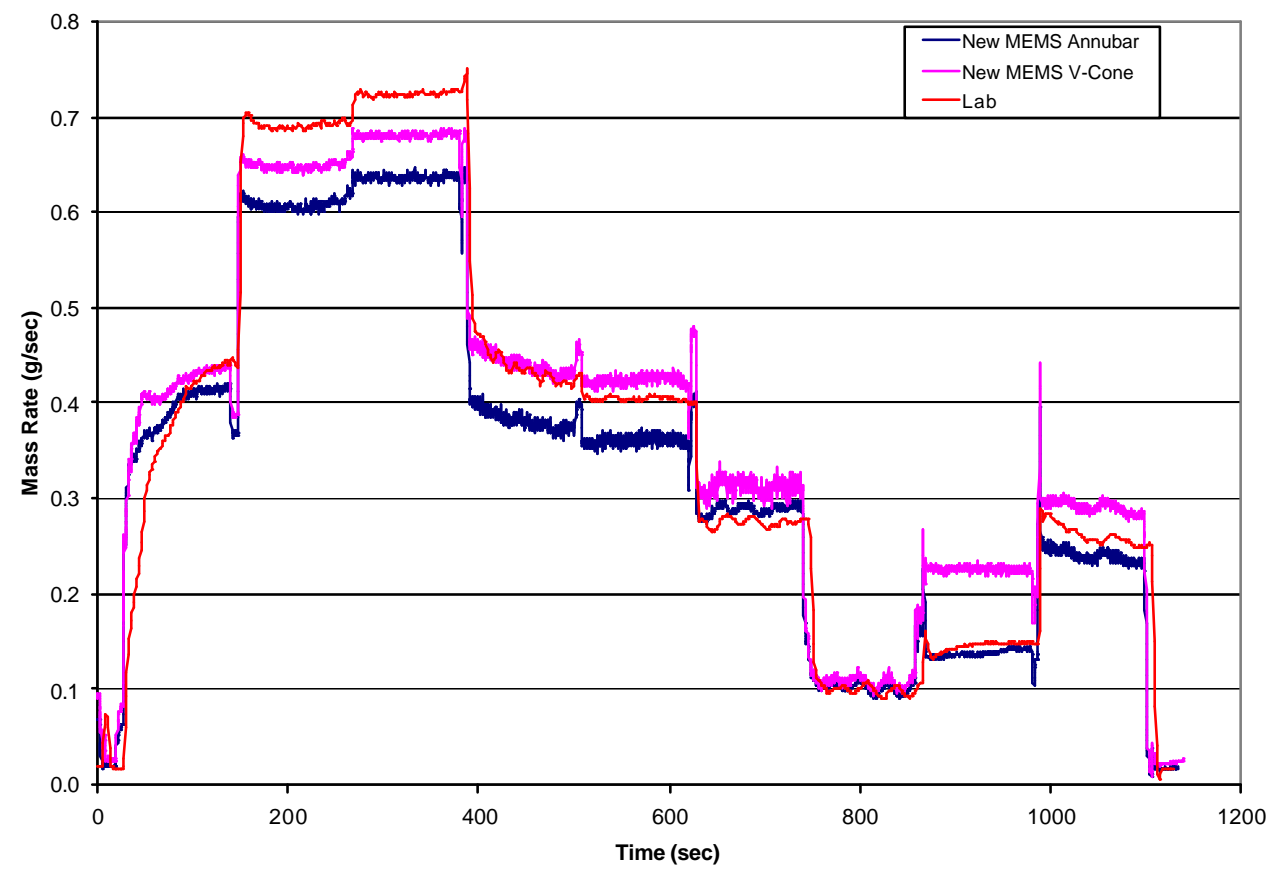

Figure 4.35 $\mathrm{NO}_{\mathrm{X}}$ mass emissions rate comparison between the V-Cone, Annubar ${ }^{\circledR}$, and Laboratory, steady state test VolvoSS2-01. 
Regression analysis was used to compare the V-Cone and Annubar ${ }^{\circledR}$ values. Regression could not be done on the Laboratory values because they were sampled at 1 $\mathrm{Hz}$ while the MEMS concentrations are measured at $5 \mathrm{~Hz}$.

Figure 4.36 and Figure 4.37 shows the regression analysis for $\mathrm{NO}_{\mathrm{X}}$ for the transient and steady state tests. Some data points far from the trend of the data points are points that have time misalignments. It is very difficult to time align the data points. And any misalignments will cause errant data points. Errant data points would in turn cause the $\mathrm{R}^{2}$ value to decrease.

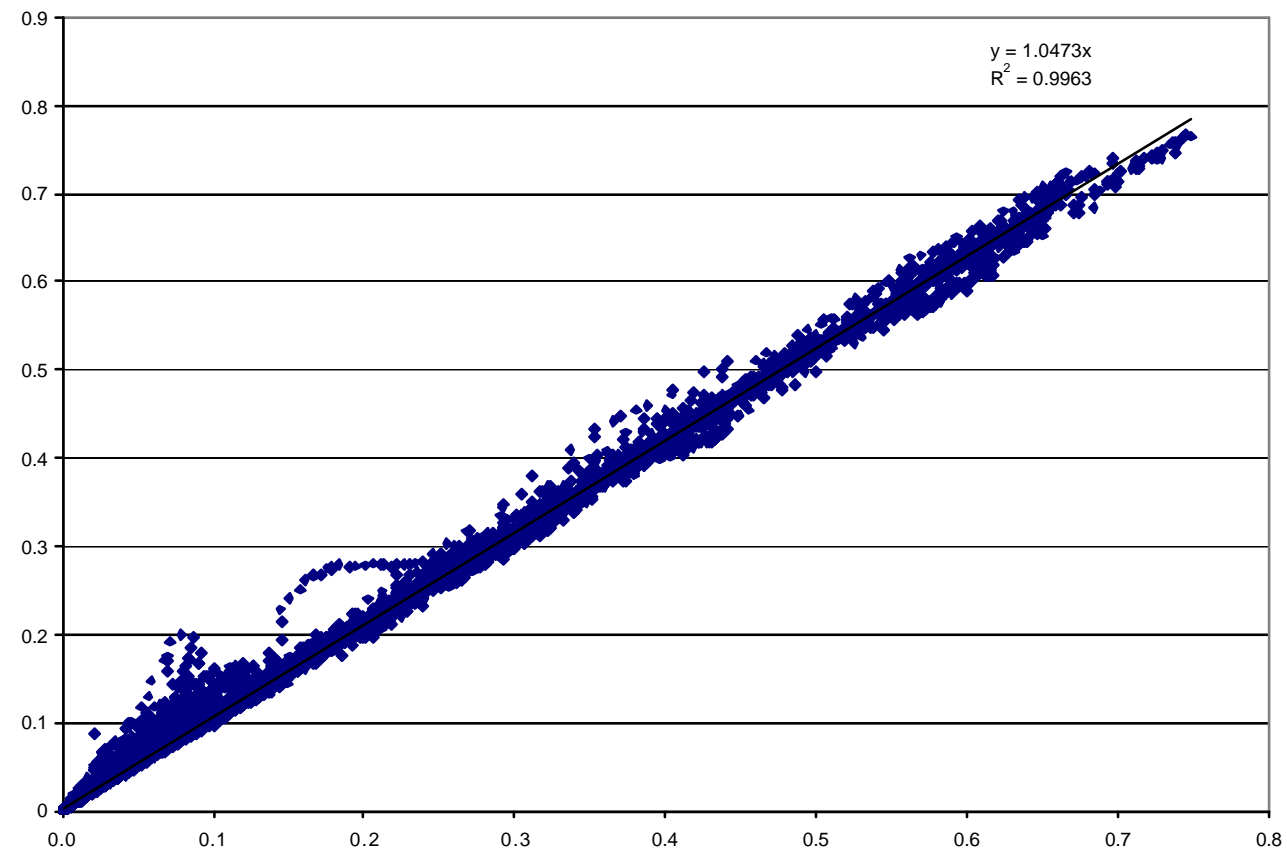

Figure 4.36 Regression analysis for $\mathrm{NO}_{\mathbf{X}}$ for test VolvoPA1 -01. 


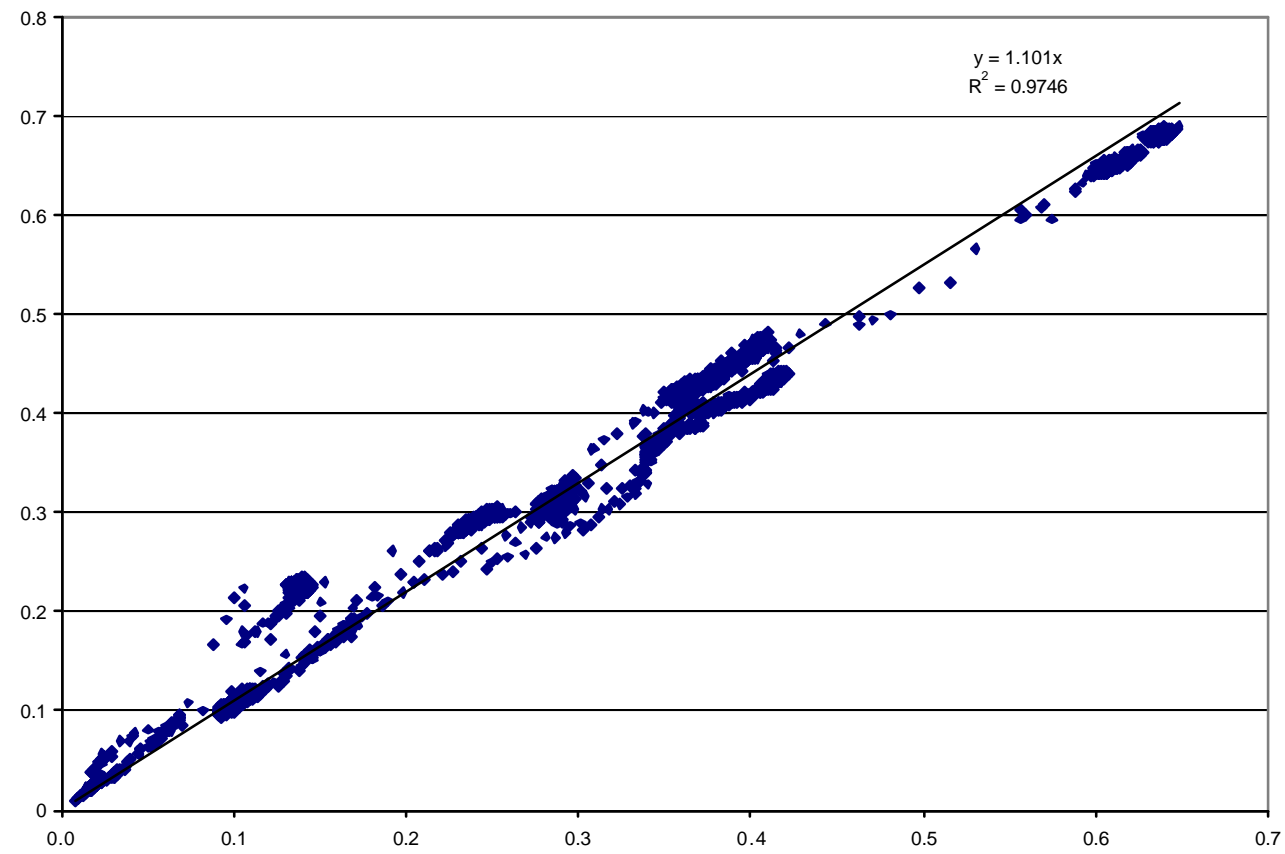

Figure 4.37 Regression analysis for $\mathrm{NO}_{\mathrm{X}}$ for test VolvoSS2-01.

The regression analysis for the $\mathrm{NO}_{\mathrm{X}}$ measurement appears to show good repeatability in the slopes of the linear fit. The difference is an amplitude shift. The VCone measures a higher flow rate than the Annubar ${ }^{\circledR}$; hence, the $\mathrm{NO}_{\mathrm{X}}$ mass rates are also higher. The $\mathrm{R}^{2}$ values for both regression analyses are close to 1.00 . However, there are data points that are errant because of the time misalignments.

Table 4.3 shows a percent difference calculation of the tests presented. (Note: the steady state tests are denoted SS2 and the transient tests PA1 in Table 4.3) The interesting thing is that the V-Cone shows better results when compared to the Lab than the Annubar ${ }^{\circledR}$ shows. The V-Cone has at least $5 \%$ better results than the Annubar ${ }^{\circledR}$ on every test. Both instruments show poor repeatable results for these tests. The Annubar ${ }^{\circledR}$ has errors up to $15 \%$, while the V-Cone has errors up to $10 \%$. All the errors are based on the laboratory values. 
Table 4.3 Integrated $\mathrm{NO}_{\mathrm{X}}$ mass rates comparison of the V-Cone, Annubar ${ }^{\circledR}$, and Laboratory with percent difference of the V-Cone and Annubar ${ }^{\circledR}$ with the Laboratory for all transient and steady state tests.

\begin{tabular}{||c|c|c|c|c|c||}
\hline Test & V-Cone & Annubar & Lab & V-Cone Difference & Annubar Difference \\
\hline volvoPA1-01 & 289 & 272 & 300 & -3.66 & -9.27 \\
\hline volvoPA1-02 & 275 & 258 & 287 & -4.18 & -10.0 \\
\hline volvoPA1-03 & 277 & 259 & 308 & -9.96 & -15.7 \\
\hline volvoPA1-04 & 308 & 289 & 343 & -10.1 & -15.7 \\
\hline volvoSS2-01 & 422 & 377 & 410 & 3.02 & -8.17 \\
\hline volvoSS2-02 & 426 & 382 & 423 & 0.81 & -9.74 \\
\hline volvoSS2-03 & 424 & 372 & 429 & -1.08 & -13.2 \\
\hline \multicolumn{7}{|l}{} \\
\hline
\end{tabular}

\section{$\mathrm{CO}_{2}$ Data}

The $\mathrm{CO}_{2}$ data was reduced and analyzed in the same manner as the $\mathrm{NO}_{\mathrm{X}}$ data. A note that around the 400 second mark, the mass emissions rates characteristics change between test volvoPA1-01 and volvoPA1-04 (see Figure 4.38 and Figure 4.39). Figure 4.38, Figure 4.39, and Figure 4.40 show direct comparison of $\mathrm{CO}_{2}$ mass emissions rates of the Laboratory, V-Cone, and Annubar ${ }^{\circledR}$. An interesting note is the order from highest to lowest mass emissions rates for $\mathrm{CO}_{2}$ is different than for $\mathrm{NO}_{\mathrm{X}}$. For $\mathrm{NO}_{\mathrm{X}}$, the order from highest mass emissions rates to lowest is Laboratory, V-Cone, and then Annubar ${ }^{\circledR}$. For $\mathrm{CO}_{2}$, the order is V-Cone, Annubar ${ }^{\circledR}$, and then Laboratory. Again, it should be noted, that for the steady state tests, mode- 8 for the V-Cone is erroneous because the flow data for the V-Cone is erroneous. 


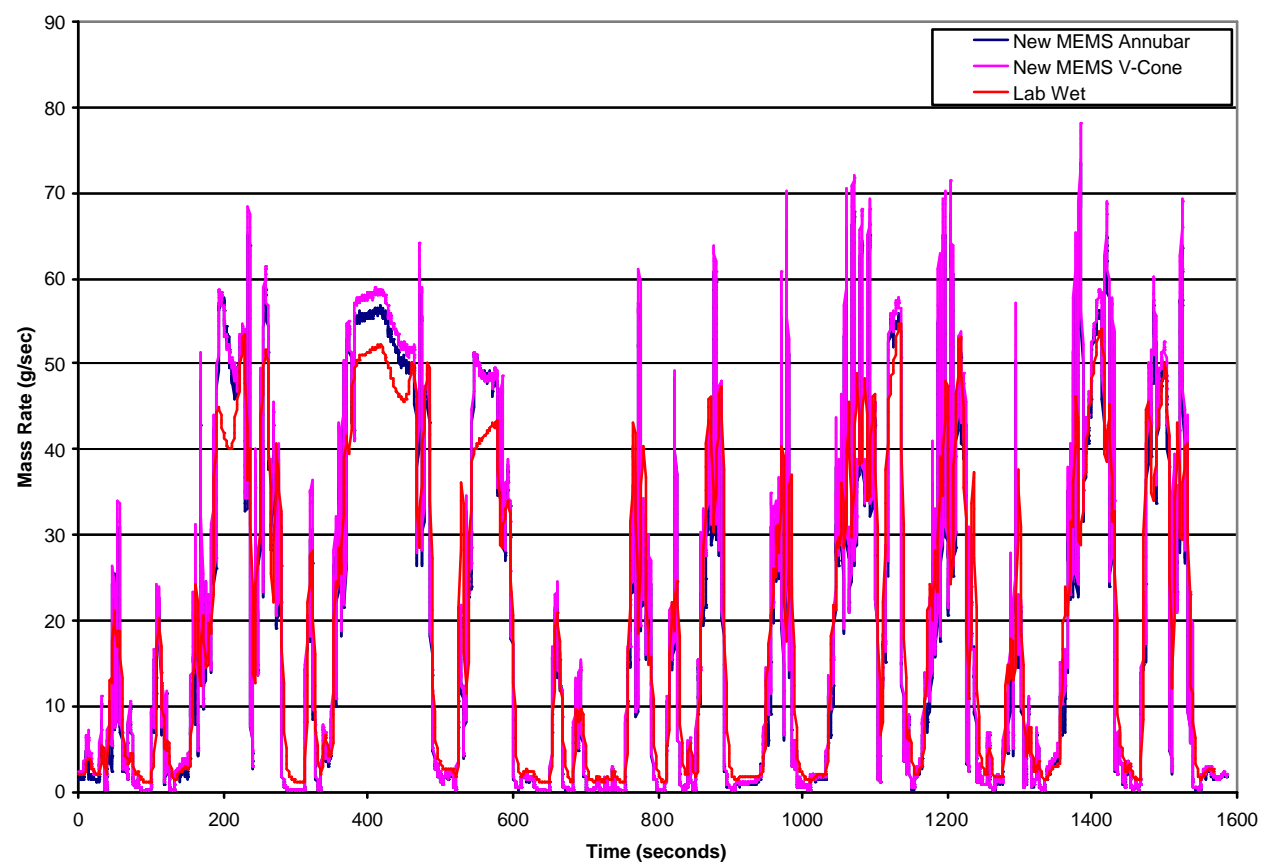

Figure 4.38 $\mathrm{CO}_{2}$ emissions mass emissions rate comparison between the $\mathrm{V}$-Cone, Annubar ${ }^{\circledR}$, and Laboratory, transient test VolvoPA1-01.

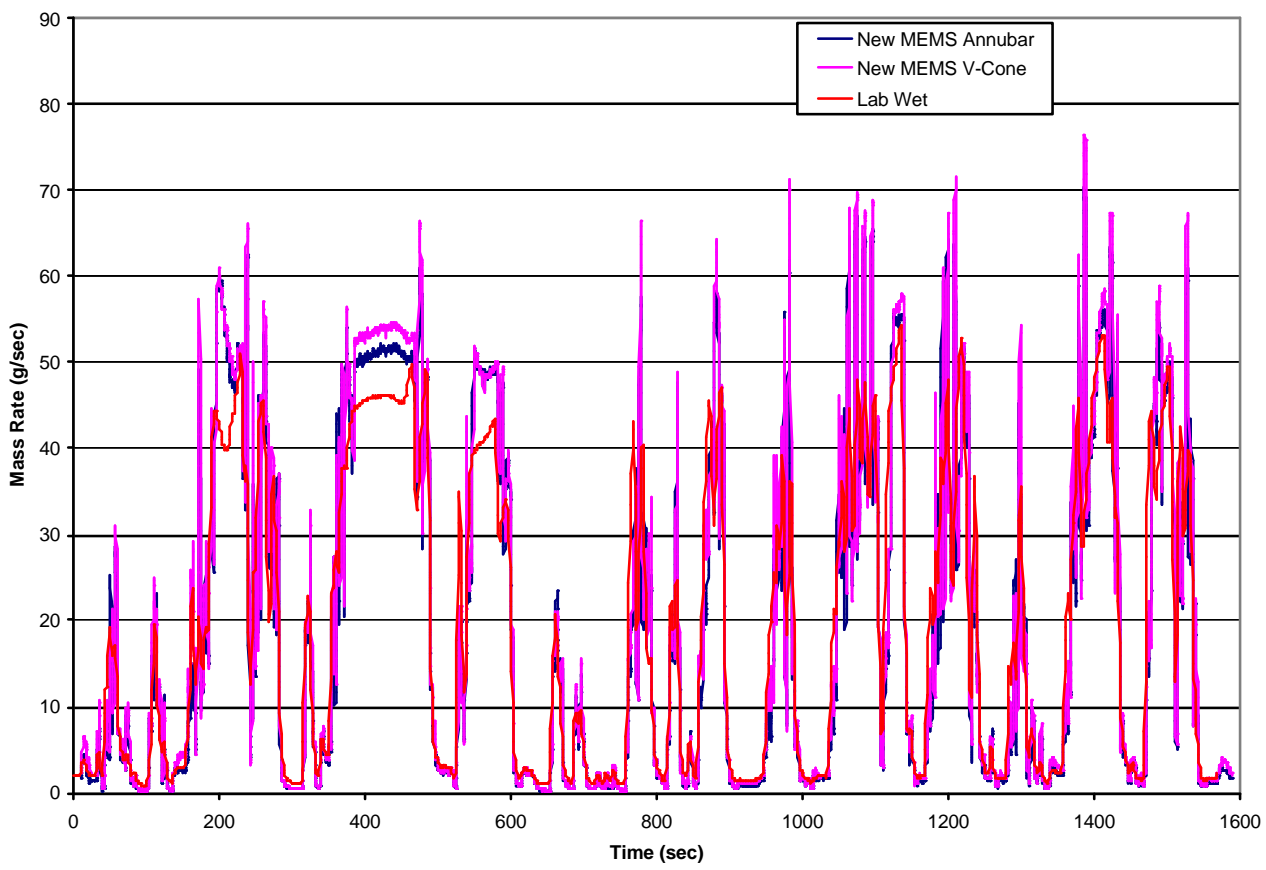

Figure 4.39 $\mathrm{CO}_{2}$ mass emissions rate comparison between the V-Cone, Annubar ${ }^{\circledR}$, and Laboratory, transient test VolvoPA1-04. 


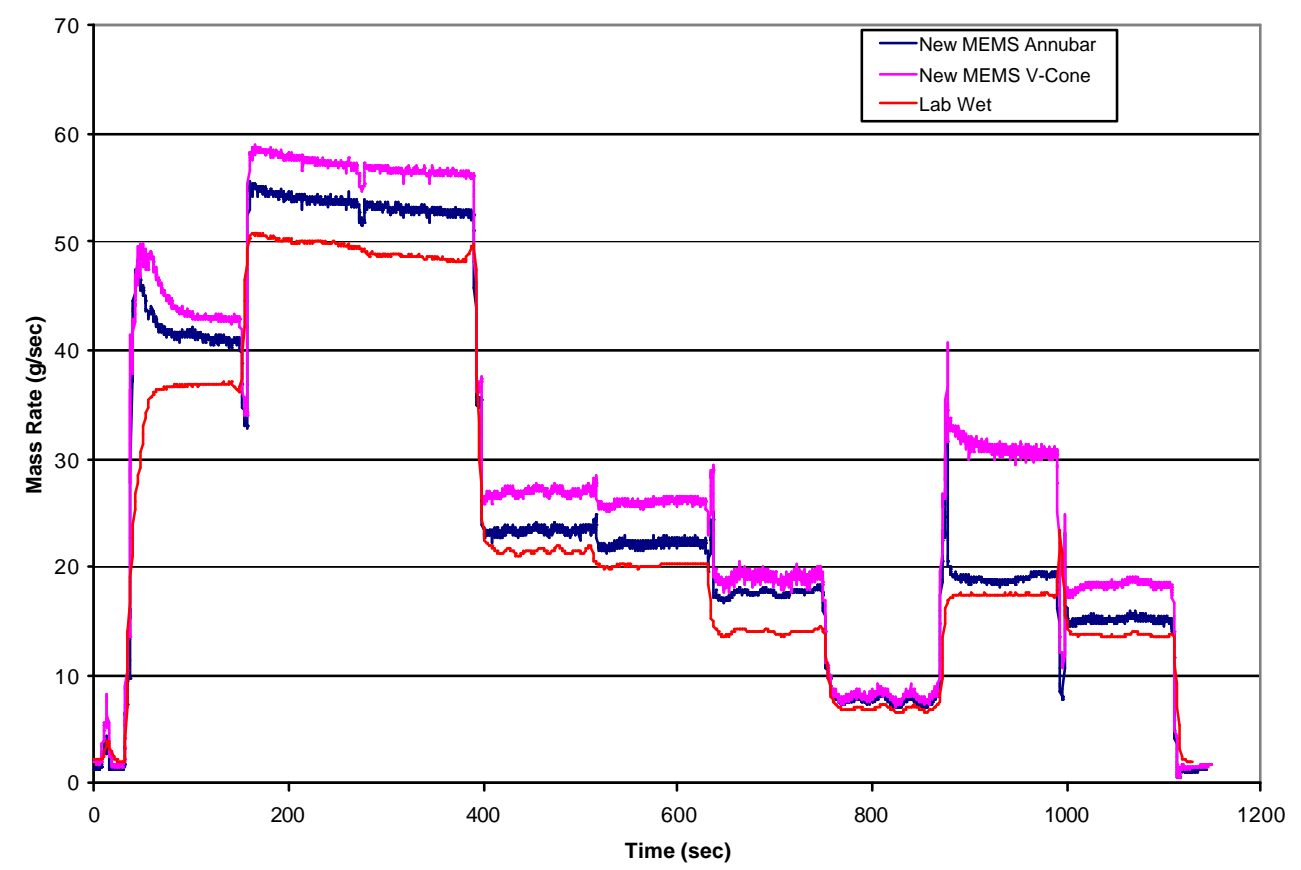

Figure 4.40 $\mathrm{CO}_{2}$ mass emissions rate comparison between the V-Cone, Annubar ${ }^{\circledR}$, and Laboratory, transient test VolvoSS2-01.

Regression analysis was done to compare the V-Cone with the Annubar ${ }^{\circledR} \mathrm{CO}_{2}$ mass emissions rates. For the transient tests, the $\mathrm{R}^{2}$ values are very close to 1.00 , and the slope of the linear fit is close to 1.00. The $\mathrm{NO}_{\mathrm{X}}$ and $\mathrm{CO}_{2}$ regression slopes for the transient tests are about 1.04. The slopes of the regression analysis for the steady state trend lines are a little worse, around 1.1. Remember that mode- 8 of the flow data is not in agreement with the Annubar ${ }^{\circledR}$; and therefore, the steady state $\mathrm{CO}_{2}$ data points from mode- 8 will also be erroneous. 
Table 4.4 Integrated $\mathrm{CO}_{2}$ mass emissions rates comparison of the V-Cone, Annubar ${ }^{\circledR}$, and Laboratory with percent difference of the V-Cone and Annubar ${ }^{\circledR}$ with the Laboratory for all transient and steady state tests.

\begin{tabular}{||c|c|c|c|c|c||}
\hline Test & V-Cone & Annubar & Lab & V-Cone Difference & Annubar Difference \\
\hline volvoPA1-01 & 32863 & 31024 & 31419 & 4.60 & -1.26 \\
\hline volvoPA1-02 & 33030 & 31083 & 31492 & 4.88 & -1.30 \\
\hline volvoPA1-03 & 34153 & 31262 & 31304 & 9.10 & -0.13 \\
\hline volvoPA1-04 & 33265 & 31308 & 30781 & 8.07 & 1.71 \\
\hline volvoSS2-01 & 34311 & 30393 & 27481 & 24.85 & 10.60 \\
\hline volvoSS2-02 & 33948 & 29979 & 27566 & 23.15 & 8.75 \\
\hline volvoSS2-03 & 34415 & 29814 & 27653 & 24.45 & 7.81 \\
\hline \multicolumn{7}{|l|}{} \\
\hline
\end{tabular}

Table 4.4 shows the percent differences of the integrated $\mathrm{CO}_{2}$ mass rate values. The $\mathrm{NO}_{\mathrm{X}}$ percent difference of the mass emissions rate values has the $\mathrm{V}$-Cone with $5 \%$ better results on every test, when compared to the Laboratory. For the $\mathrm{CO}_{2}$ percent difference values, the Annubar ${ }^{\circledR}$ is significantly better than the V-Cone, especially for the steady state tests. For the steady state tests, the V-Cone has more than $20 \%$ error. The V-Cone measures higher flow rates and thus higher mass emissions rates. There is a constant offset between the V-Cone and the test cell, except for mode- 8 . This accounts for the great errors, although neither of the instruments (the V-Cone or the Annubar ${ }^{\circledR}$ ), for the steady state tests, have acceptable errors. The Annubar ${ }^{\circledR}$ has more than $7 \%$ error for each steady state test, when compared to the Laboratory. All $\mathrm{CO}_{2}$ graphs can be seen in Appendix D. 


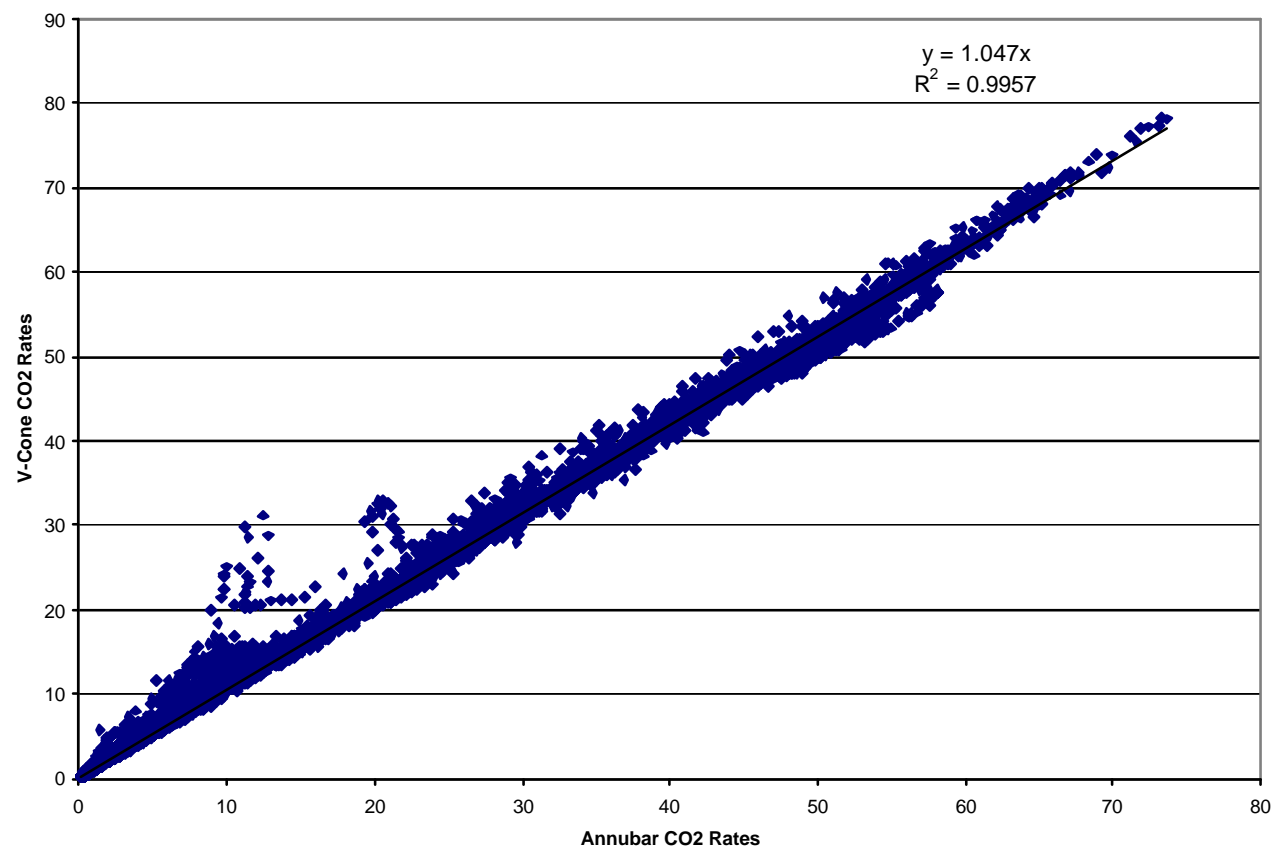

Figure 4.41 $\mathrm{CO}_{2}$ regression analysis for test VolvoPA1-01.

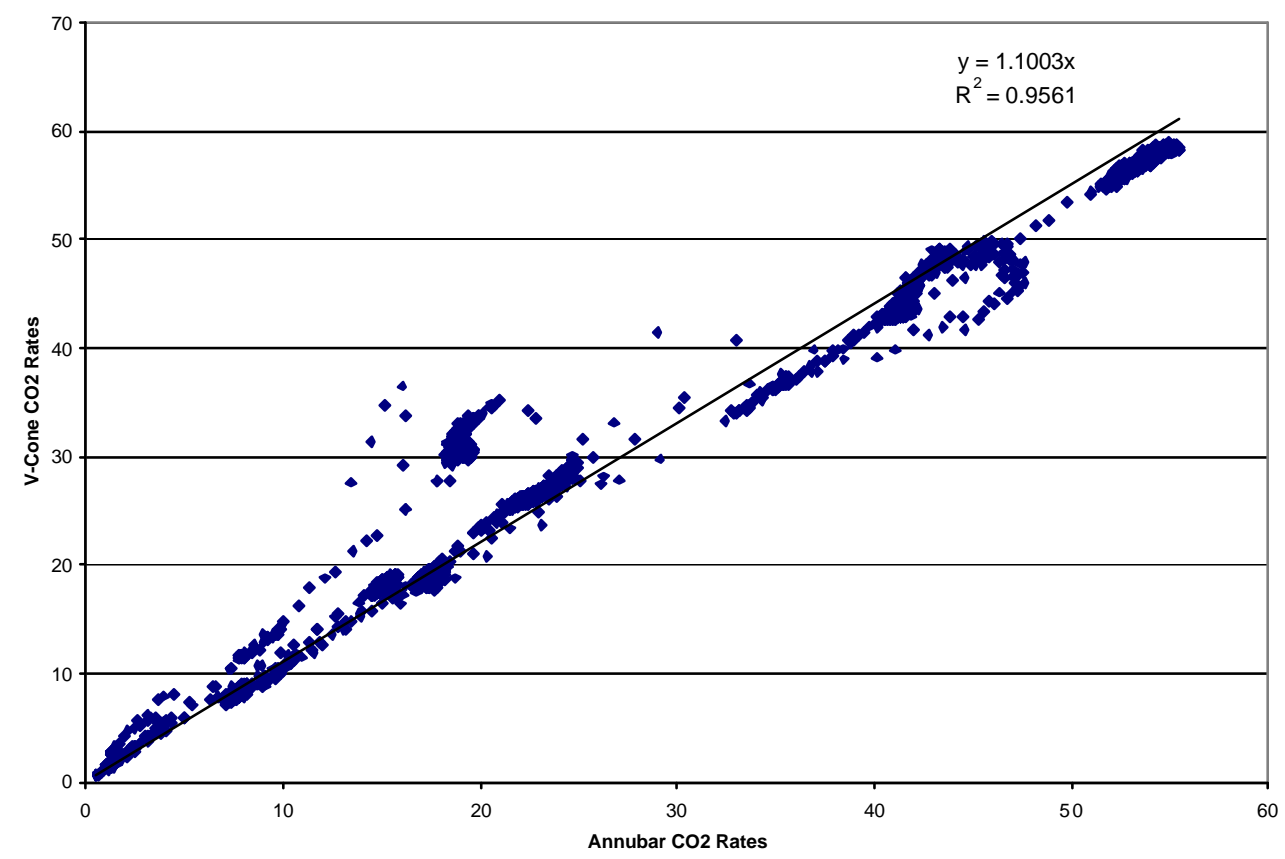

Figure 4.42 $\mathrm{CO}_{2}$ regression analysis for test VolvoSS2-01. 
Table 4.5 shows the percent differences between the measured V-Cone and Annubar ${ }^{\circledR}$ values. Table 4.6 shows the percent differences between the measured Annubar $^{\circledR}$ and the V-cone after the average slope was divided in.

Table 4.5 Differences between the measured V-Cone and the measured Annubar ${ }^{\circledR}$ mass emissions rates.

\begin{tabular}{|c|c|c|c|}
\hline Test & Measured V-Cone & Measured Annubar & \% Diff \\
\hline volvoPA1-01 NOX & 289 & 272 & 6.18 \\
\hline volvoPA1-01 CO2 & 32863 & 31024 & 5.93 \\
\hline volvoPA1-02 NOX & 275 & 258 & 6.49 \\
\hline volvoPA1-02 CO2 & 33030 & 31083 & 6.26 \\
\hline volvoPA1-03 NOX & 277 & 259 & 6.84 \\
\hline volvoPA1-03 CO2 & 34153 & 31262 & 9.25 \\
\hline volvoPA1-04 NOX & 308 & 289 & 6.53 \\
\hline volvoPA1-04 CO2 & 33265 & 31308 & 6.25 \\
\hline volvoSS2-01 NOX & 422 & 377 & 12.2 \\
\hline volvoSS2-01 CO2 & 34311 & 30393 & 12.89 \\
\hline volvoSS2-02 NOX & 426 & 382 & 11.7 \\
\hline volvoSS2-02 CO2 & 33948 & 29979 & 13.24 \\
\hline volvoSS2-03 NOX & 424 & 372 & 13.9 \\
\hline volvoSS2-03 CO2 & 34415 & 29814 & 15.43 \\
\hline \multicolumn{4}{|l|}{} \\
\hline
\end{tabular}

Table 4.6 Differences between the V-Cone with corrected values and the measured Annubar $^{\circledR}$ mass emissions rates.

\begin{tabular}{|c|c|c|c|c|}
\hline Test & Measured V-Cone & Corrected V-Cone & Measured Annubar & $\%$ Diff \\
\hline volvoPA1-01 NOX & 289 & 275 & 272 & 1.10 \\
\hline volvoPA1-01 CO2 & 32863 & 31289 & 31024 & 0.86 \\
\hline volvoPA1-02 NOX & 275 & 262 & 258 & 1.39 \\
\hline volvoPA1-02 CO2 & 33030 & 31448 & 31083 & 1.17 \\
\hline volvoPA1-03 NOX & 277 & 264 & 259 & 1.72 \\
\hline volvoPA1-03 CO2 & 34153 & 32518 & 31262 & 4.02 \\
\hline volvoPA1-04 NOX & 308 & 293 & 289 & 1.43 \\
\hline volvoPA1-04 CO2 & 33265 & 31672 & 31308 & 1.16 \\
\hline volvoSS2-01 NOX & 422 & 402 & 30393 & 6.81 \\
\hline volvoSS2-01 CO2 & 34311 & 32667 & 382 & 7.48 \\
\hline volvoSS2-02 NOX & 426 & 406 & 29979 & 6.34 \\
\hline volvoSS2-02 CO2 & 33948 & 32322 & 372 & 7.82 \\
\hline volvoSS2-03 NOX & 424 & 404 & 29814 & 8.50 \\
\hline volvoSS2-03 CO2 & 34415 & 32767 & & 9.90 \\
\hline \multicolumn{2}{|l|}{} & & &
\end{tabular}


After the slope is averaged and the V-Cone values are corrected, the percent difference drops by more than half. Generally, the corrected V-Cone values are more accurate with the Laboratory than the Annubar ${ }^{\circledR}$ values, but remember that the V-Cone was corrected back to the Annubar ${ }^{\circledR}$. Table 4.7 shows the differences when compared with the Laboratory values. The $\mathrm{NO}_{\mathrm{X}}$ errors are much less than $\mathrm{CO}_{2}$ errors for all comparisons. The test with the worst errors is the steady state test for $\mathrm{CO}_{2}$ analysis. Remember that reducing the errors between the V-Cone and Annubar ${ }^{\circledR}$ does not mean that it decreases the errors with the Laboratory as well. There are still large differences between the Lab, V-Cone corrected, and Annubar ${ }^{\circledR}$ (see Table 4.8).

Table 4.7 Percent differences between the corrected V-Cone and Annubar ${ }^{\circledR}$ mass emissions rates with the Laboratory values. The corrected V-Cone corrects to the Annubar ${ }^{\circledR}$ data, not the Laboratory data.

\begin{tabular}{|c|c|c|c|c|c|c|}
\hline Test & Corrected & Measured & Lab & Corrected & Annubar & V-Cone Annubar \\
\hline & V-Cone & Annubar & & V-Cone \% Diff & $\%$ Diff & $\%$ Diff \\
\hline volvoPA1-01 NOX & 275 & 272 & 300 & -8.27 & -9.27 & 1.10 \\
\hline volvoPA1-01 CO2 & 31289 & 31024 & 31419 & -0.41 & -1.26 & 0.86 \\
\hline volvoPA1-02 NOX & 262 & 258 & 287 & -8.76 & -10.01 & 1.39 \\
\hline volvoPA1-02 CO2 & 31448 & 31083 & 31492 & -0.14 & -1.30 & 1.17 \\
\hline volvoPA1-03 NOX & 264 & 259 & 308 & -14.27 & -15.72 & 1.72 \\
\hline volvoPA1-03 CO2 & 32518 & 31262 & 31304 & 3.88 & -0.13 & 4.02 \\
\hline volvoPA1-04 NOX & 293 & 289 & 343 & -14.5 & -15.7 & 1.43 \\
\hline volvoPA1-04 CO2 & 31672 & 31308 & 30781 & 2.90 & 1.71 & 1.16 \\
\hline volvoSS2-01 NOX & 402 & 377 & 410 & -1.91 & -8.17 & 6.81 \\
\hline volvoSS2-01 CO2 & 32667 & 30393 & 27481 & 18.87 & 10.60 & 7.48 \\
\hline volvoSS2-02 NOX & 406 & 382 & 423 & -4.02 & -9.74 & 6.34 \\
\hline volvoSS2-02 CO2 & 32322 & 29979 & 27566 & 17.25 & 8.75 & 7.82 \\
\hline volvoSS2-03 NOX & 404 & 372 & 429 & -5.82 & -13.2 & 8.50 \\
\hline volvoSS2-03 CO2 & 32767 & 29814 & 27653 & 18.49 & 7.81 & 9.90 \\
\hline
\end{tabular}


Table 4.8 Percent difference of integrated values comparing the V-Cone and Annubar $^{\circledR}$ mass emissions rates, without correcting the V-Cone values to the Annubar ${ }^{\circledR}$ values, to the Laboratory values.

\begin{tabular}{|c|c|c|c|c|c|}
\hline Test & V-Cone & Annubar & Lab & V-Cone Difference & Annubar Difference \\
\hline volvoPA1-01 NOX & 289 & 272 & 300 & -3.66 & -9.27 \\
\hline volvoPA1-02 NOX & 275 & 258 & 287 & -4.18 & -10.0 \\
\hline volvoPA1-03 NOX & 277 & 259 & 308 & -9.96 & -15.7 \\
\hline volvoPA1-04 NOX & 308 & 289 & 343 & -10.2 & -15.7 \\
\hline volvoSS2-01 NOX & 422 & 377 & 410 & 3.02 & -8.17 \\
\hline volvoSS2-02 NOX & 426 & 382 & 423 & 0.81 & -9.74 \\
\hline volvoSS2-03 NOX & 424 & 372 & 429 & -1.08 & -13.2 \\
\hline volvoPA1-01 CO2 & 32863 & 31024 & 31419 & 4.60 & -1.26 \\
\hline volvoPA1-02 CO2 & 33030 & 31083 & 31492 & 4.88 & -1.30 \\
\hline volvoPA1-03 CO2 & 34153 & 31262 & 31304 & 9.10 & 1.71 \\
\hline volvoPA1-04 CO2 & 33265 & 31308 & 30781 & 8.07 & 10.60 \\
\hline volvoSS2-01 CO2 & 34311 & 30393 & 27481 & 24.85 & 8.75 \\
\hline volvoSS2-02 CO2 & 33948 & 29979 & 27566 & 23.15 & 7.81 \\
\hline volvoSS2-03 CO2 & 34415 & 29814 & 27653 & 24.45 & \\
\hline
\end{tabular}

The steady state test percent errors do not decrease as much as the transient tests percent errors. The slopes of the steady state trend lines from regression analysis are also greater than the slopes from the transient tests. The change in slopes is due to mode- 8 of the steady state. Mode- 8 affects the trend line by pulling it towards the pocket of data points out of the trend. Note: the slope of the transient tests is 1.05 , the slope of the steady state tests averages 1.10 . Table 4.9 shows the percent errors using the average slopes of the steady state tests corrected V-Cone. As you can see, the errors are all less than $5 \%$.

Table 4.9 Percent differences between the corrected V-Cone values and the measured Annubar ${ }^{\circledR}$ values of mass emissions rates using the average slope of the steady state test regression.

\begin{tabular}{|c|c|c|c|c|}
\hline Test & Measured V-Cone & Corrected V-Cone & Measured Annubar & $\%$ Diff \\
\hline volvoSS2-01 NOX & 422 & 384 & 377 & 1.92 \\
\hline volvoSS2-01 CO2 & 34311 & 31172 & 30393 & 2.56 \\
\hline volvoSS2-02 NOX & 426 & 387 & 382 & 1.47 \\
\hline volvoSS2-02 CO2 & 33948 & 30842 & 29979 & 2.88 \\
\hline volvoSS2-03 NOX & 424 & 385 & 372 & 3.53 \\
\hline volvoSS2-03 CO2 & 34415 & 31267 & 29814 & 4.87 \\
\hline \multicolumn{7}{|l|}{} \\
\hline
\end{tabular}


The V-Cone measures the flows, $\mathrm{NO}_{\mathrm{X}}$ and $\mathrm{CO}_{2}$ mass emissions rates greater than the Annubar ${ }^{\circledR}$. If the factor is included into the equation, the V-Cone is within $2 \%$ for most tests with the Annubar ${ }^{\circledR}$.

Without correcting the V-Cone back to the Annubar ${ }^{\circledR}$, the comparison (Table 4.8) shows that the V-Cone is better than the Annubar ${ }^{\circledR}$ for all $\mathrm{NO}_{\mathrm{X}}$ tests. For the $\mathrm{CO}_{2}$ tests, the Annubar ${ }^{\circledR}$ is much better than the V-Cone. The V-Cone has less than $10 \%$ error maximum, with most errors being less than $5 \%$, for the $\mathrm{NO}_{\mathrm{X}}$ values. For the $\mathrm{CO}_{2}$ values, the V-Cone transient test has errors less than $10 \%$, but nearly $25 \%$ for the steady state tests. The Annubar ${ }^{\circledR}$ average errors are about $12 \%$ for $\mathrm{NO}_{\mathrm{X}}$ and average errors of $4.5 \%$ for $\mathrm{CO}_{2}$ (both transient and steady state error averages). The Annubar ${ }^{\circledR}$ has much better results for the transient tests than the steady state tests.

For the calculation of the mass rates, the only difference between the Annubar ${ }^{\circledR}$ and $\mathrm{V}$-Cone is the flow rates. The concentration of $\mathrm{NO}_{\mathrm{X}}$ and $\mathrm{CO}_{2}$ used to calculate the mass rates was the same, obtained from the second generation MEMS. 


\section{Chapter 5 Conclusion}

\subsection{Signal Model 3030PM Portable VOC Hydrocarbon Analyzer}

With the development of on-board, real-time emissions measurements, increasing the capabilities and accuracies of these systems are of utmost importance. Currently, WVU's MEMS system measures $\mathrm{CO}_{2}$ and $\mathrm{NO}_{\mathrm{X}}$ to within $5 \%$ of laboratory grade instruments. There are more emissions polluted from diesel engines than $\mathrm{NO}_{\mathrm{X}}$ and $\mathrm{CO}_{2}$, and they need to be measured as well. Due the rigorous demands of the on-road testing environment, instrumentation for emissions such as, $\mathrm{CO}$ and THC need to be robust and accurate to allow on-board measurements.

The investigation of the Signal Model 3030PM HFID hydrocarbon analyzer showed that it is possible to integrate a heated Hydrocarbon FID into the MEMS system.

The scope of this thesis included validation of the accuracy of the HFID. Signal Model 3030PM is a portable system, but the robustness of the analyzer was not tested for this thesis, and no on-board, on-road tests were performed on the analyzer.

In addition to having equal or better accuracy than the laboratory grade analyzer currently in use, several other characteristics of the Model 3030PM had were found to be valuable. Since the Model 3030PM had better response than the Model 402, the regression analysis, when comparing the two analyzers, was poor. Capturing the high and low concentrations, by having a better response, gives a better representation of the HC output during a transient test cycle.

A problem that showed up after this testing, was the possibility of hydrocarbon hang-up in the Model 3030PM. After a long test, with the Model 3030PM sampling for 
long periods of time (30-60 minutes), the analyzer did not return to zero when zero air was passed through the analyzer for the zeroing and spanning of the analyzers. The Model 3030PM returned to within $2 \%$ of the zero for a $60 \mathrm{ppm}$ methane equivalent span value very rapidly. However, it took several minutes, sometimes as much as 15 minutes, for the analyzer to finally return to zero. A reason could be that the instrument was not designed for diesel engine emissions, and the high PM that the engines produce. The exhaust sample passed through the analyzer for these tests was the dilute stream. For MEMS, the Signal needs to be able to handle raw exhaust. If there is hydrocarbon hangup from the dilute exhaust, there would be significantly more in raw exhaust.

The Signal 3030PM HFID hydrocarbon analyzer performed equal to or better than the Rosemount Analytical 402 HFID analyzer for each of the comparative tests. These tests were conducted on a dilute sample. As a THC analyzer, the Signal Model 3030PM is a better instrument. Depending upon its robustness, the Signal Model 3030PM should be considered for integration into the MEMS system to increase the emissions that MEMS measures. The size of the Signal analyzer is compact enough that it can be incorporated into on-board measurement system.

Note: The Signal has several features that are not required for measurement of hydrocarbons. As an example, the analyzer is equipped with a methane cutter. MEMS does not need these features in the immediate future. Therefore, a possibility is to develop a more compact, simpler HFID for specific use in MEMS and/or other portable on-board emissions me asurement systems.

The error between the Signal Model 3030PM and the Rosemount Analytical Model 402 is less than $5 \%$ for most of the tests. A drift was observed in the Signal 
Model 3030PM analyzer during the transient tests toward the end of the tests. But the error is still within the $5 \%$ error. For the Signal to be validated for use in the MEMS system the problems listed above need to be addressed.

Testing should be conducted on the Signal Model 3030PM using raw exhaust as the sample stream, to determine the ability of the analyzer to handle raw exhaust measurements.

\subsection{McCrometer's V-Cone Flow Meter}

For the V-Cone to be an adequate flow meter, it must be comparable to the Annubar ${ }^{\circledR}$ which is currently used. The Annubar and its accuracy were investigated and presented in the MEMS Phase I and Phase II reports [18, 19].

The differences between the V-Cone and Annubar ${ }^{\circledR}$ are consistent, but the differences with the Laboratory are erratic. If the goal of the study was to compare the V-Cone with just the Annubar ${ }^{\circledR}$, a factor can be used to make the errors less than $2 \%$. For some transient tests, the V-Cone is within $2 \%$ of the Laboratory, but for some, namely the steady state $\mathrm{CO}_{2}$, the V-Cone is $25 \%$ off. The Annubar ${ }^{\circledR}$ provides better results, but still not the accuracy desired. With the Laboratory as the standard, and accuracy needs for both $\mathrm{NO}_{\mathrm{X}}$ and $\mathrm{CO}_{2}$, more testing needs to be done to ensure the accuracy of the $\mathrm{V}$-Cone for automotive exhaust measurement.

Given that the V-Cone is more compact and doesn't require fully developed flow warrants more testing of the V-Cone to ensure accurate results. The only difference between the V-Cone and Annubar ${ }^{\circledR}$ is the flow rates inputted into the mass rate equations. 
The advantages and possibilities that the V-Cone is great, but if the V-Cone does not have the accuracy needed for laboratory grade measurements, the compactness and conditioning of the flow doesn't matter.

Other problems with the V-Cone are the weight of the V-Cone for the application of on-board measurements and the pressure issue that arose in mode- 8 of the steady state tests. The current configuration of V-Cone has too much mass and therefore weighs too much for on-board application. The other problem that needs to be looked at is what caused the differential pressure reading differences during mode- 8 in the steady state. 


\section{Chapter 6 Recommendations}

The Signal Model 3030PM was tested using a diluted exhaust sample. For mobile emissions measurement, the instruments need to sample raw exhaust. Therefore, the Signal Model 3030PM needs to be tested sampling raw exhaust.

The Laboratory and MEMS need to collect data points at the same frequency for direct comparison of the Laboratory with MEMS. This would allow for more comparisons between the Laboratory and MEMS using the different flow meters. The use of regression analysis could then be used to evaluate the instruments with the Laboratory.

Investigation of reasons why the flow meters reacted differently for mode- 8 of the steady state tests needs to be conducted.

Correspondence with McCrometer to reconfigure the V-Cone to make it lighter needs to be done for the V-Cone to have the possibility for on-board measurements. If the V-Cone could be made out of thinner material instead of schedule 40 pipe, this problem could be solved. But any changes in the V-Cone need to be done without adversely affecting the measurement accuracy of the instrument. 


\section{Chapter 7 REFERENCES}

1. 3030PM Portable Heated VOC Analyser Operating Manual, The Signal Instrument Co, Ltd., First Edition, December 1, 1993, Surrey, England.

2. Arcourmanis, C. and Megaritis, A., "Real-Time Measurement of Particulate Emissions in a Turbocharged DI Diesel Engine," SAE Paper 922390, 1992.

3. Bentz, A. P. and Weaver, E., "Marine Diesel Exhaust Emissions Measured by Portble Instruments," SAE Technical Paper No. 941784, 1994.

4. Bentz, A. P., "Final Summary Report on Project 3310, Marine Diesel Exhaust Emissions (Alternative Fuels)," United States Department of Transportation United States Coast Guard Systems, Report No. CG-D-08-98, 1997.

5. Bransetter, R., Burrahm, r., and Dietzmann, H., "Relationship of Underground Diesel Engine Maintenance to Emission," Final Report for 1978 to 1983 to the US Bureau of Mines, Department of the Interior Contract H029009, 1983.

6. Butler, J. W., Gierczak, C. A., Jesion, G., Stedman, D. H., and Lesko, J. M., "OnRoad NOX Emissions Intercomparison of On-BoardMeasurements and Remote Sensing," Final Report, Coordinating Council, Inc., Atlanta, GA, CRC Report No. VE-11-6, 1994.

7. Butler, J. W., Kornisk, T. J., Reading, A. R., and Kotenko, T. L., "Dynamometer Quality Data On-board Vehicles for ReatWorld Emissions Measurement," Proceedings of the 9th CRC On-Road Vehicles Workshop, April 19-21, San Diego, CA, 1999.

8. Chan, L., Carlson, D. H., and Johnson, J. H., "Evaluation and Application of a Portable Tailpipe Emissions Measurement Apparatus for Field Use," SAE Technical Paper No. 921647, 1992.

9. Code of Federal Regulations 40, Part 86, Subpart N, Washington, D.C.,1994

10. Code of Federal Regulations 40, Part 89, Washington, D.C., 1994

11. "Construction Equipment Retrofit Project," Northeast States for Coordinated Air Use Management, Boston, MA, 1998

12. Czachura, B., Brandon, L., May, A., "Demonstration of the 'Simple, Portable OnVehicle Testing' (SPOT) System on a Class 8 Vehicle," Proceedings of the $11^{\text {th }}$ CRC On-Road Vehicle Emissions Workshop, 2001

13. Dahlstrom, M. J., "V-Cone meter: Gas measurement in the real world," Phillips Petroleum Company Norway, 1994.

14. Englund, M. S., "Field Compatible NOX Emission Measurement Technique," SAE Technical Paper No. 820647, 1982.

15. Gautam, M., Carder, D., Clark, N., and Lyons, D., "Testing for Exhaust Emissions of Diesel Powered Off-Road Engines," ARB Contract Number 98-317 Final Report, May 29, 2002.

16. Gautam, M., Riddle, W., Thompson, G., Carder, D., Clark, N., Lyons, D., "Measurement of Brake Specific $\mathrm{NO}_{\mathrm{X}}$ Emissions using Zirconia Sensors for In-use, On-board Heavy-duty Vehicle Application," SAE Paper 202-00-1755, 2002.

17. Gautam, M., Thompson, G., Clark, N., Carder, D., Wayne, S., and Lyons, D., "Development of a Test Method to Measure Stationary and Portable Engine Emission," Proposal to CARB, Ayala, A., November 30, 2000. 
18. Gautam, M., Thompson, G., Clark, N., Lyons, D., "Assessment of Mobile Monitoring Technologies for Heavy-Duty Vehicle Emissions," Department of Mechanical and Aerospace Engineering, West Virginia University, Morgantown, WV, 1999.

19. Gautam, M., Thompson, G., Clark, N., Lyons, D., "Evaluation of Mobile Monitoring Technologies for Heavy-Duty Vehicle Emissions," Department of Mechanical and Aerospace Engineering, West Virginia University, Morgantown, WV, 2000.

20. Gierczak, C. A., Jesion, G., Piatak, J. W., and Butler, J. W., "On-Board Vehicle Emissions Measurement Program," Final Report, Coordinating Research Council, Inc., Atlanta, GA, CRC Report No. VE-11-1, 1994.

21. Human, D. M., and Ullman, T. L., "Development of an I/M Short Emissions Test for Buses," SAE Technical Paper No. 920727, 1992.

22. Ifft, S. A., "Permanent Pressure Loss comparison Among Various Flowmeter Technologies," McCrometer Inc., www.mccrometer.com/library/9811/lit_vc.htm

23. Ifft, S. A., "V-Cone, An Alternative to Orifice Meter in Wet Gas Applications," McCrometer Inc., Norflow99, 1999.

24. Ifft, S. A., Mikkelson, E. D., "Pipe Elbow Effects on the V-Cone Flow meter," Presented at ASME Fluids Engineering Conference, 1993, Washington, D.C

25. Installation Manual-Horiba Model BE-140 AD Production Type Exhaust Gas Analyzer, Horiba, Ltd. First Edition, June 30. 1997, Kyoto, Japan.

26. Instruction Manual-Mexa 120 NOX Analyzer, Horiba, Ltd. First Edition, Ver. 1.0, September, 1998, Kyoto, Japan.

27. Janke, J. A., Continuous Emissions Monitoring, Van Nostrand Reinhold, New York, 1993.

28. Jetter, J., Maeshiro, S., Hatcho, S., and Klubba, R., "Development of an On-Board Analyzer for Use on Advanced Low Emission Vehicles," SAE Technical Paper No. 2000-01-1140, 2000.

29. Kawai, T., Iuchi, Y., Nakamura, S., and Ishido, K., "Real Time Analysis of Particulate Matter by Flame Ionization Detection," SAE Paper 980048, 1998.

30. Kelly, N. A. and Groblicki, P. J., "Real-world emissions from a modern production vehicle driven in Los Angeles," Journal of the Air \&Waste Management Association, Vol. 43, No. 10, 1993.

31. Kihara, N., Tsukamoto, T., Matsumotao, K., Ishida, K., Kon, M., and Murase, T., "Real-Time On-Board measurement of Mass Emissions of NOX, Fuel Consumption, Road Load, and Engine Output for Diesel Vehicles," SAE Technical Paper No. 200001-1141, 2000.

32. Lawrence, P. A., "Field Experiences with V-Cone Technology," McCrometer Inc., www.mccrometer.com, 2002

33. Mackey, G. I., Nadler, S. D., Karecki, D. R., Schiff, H. I., Butler, J. W., Geirczak, C. A., and Jesion, G., "Dynamometer Intercomparison of Automobile Exhaust Gas $\mathrm{CO} / \mathrm{CO} 2$ Ratios and Temperature Between On-Board Measurements and a Remote Sensing Near Infrared Diode Laser System," Phase 1b Report to the Coordinating Research Council and National Renewable Energy Laboratory, 1994.

34. Mackey, G. I., Nadler, S. D., Karecki, D. R., Schiff, H. I., Butler, J. W., Geirczak, C. A., and Jesion, G., "Test Track Intercomparison of Automobile Exhaust Gas CO/CO2 Ratios and Temperature Between On-Board Measurements and a Remote Sensing 
Near Infrared Diode Laser System," Phase 1c Report to the Coordinating Council and National Renewable Energy Laboratory, 1994.

35. Nitric Oxide Sensor- Operating Instructions, City Technology Ltd., Portsmouth, UK, 1999.

36. Reading, A., Gideon, E., and Ensfield, C., "The Design and Implementation of a Portable Analytical System (SEMTECH) for the Measurement of In-Use Diesel Engine Emissions," Proceedings of the $11^{\text {th }}$ CRC On-Road Vehicle Emissions Workshop, 2001.

37. Scarboro, C., "An Investigation of the ROVER's Capabilities to Accurately Measure the In-Use Activity and Emissions of Late-Model Diesel and Gasoline Trucks," Proceedings of the 10th CRC On-Road Vehicle Emissions Workshop, San Diego, CA, March 27-29, 2000.

38. Spears, M. W., "An Emissions-Assisted Maintenance Procedure for Diesel-Powered Equipment," University of Minnesota, Center for Diesel Research, Minneapolis, MN, 1997.

39. Vojtisek-Lom, M. and Cobb, Jr., J. T., "On-Road Light-Duty Vehicle Mass Emissions Measurements Using a Novel Inexpensive On-Board Portable System," Proceedings of the Eighth CRC On-Road Vehicle Workshop, San Diego, CA, April 20-22, 1998.

40. www.cert.ucr.edu/research/trailer.asp

41. www.cleanairt.com/products_heavy_duty.html

42. www.cleanairt.com/products_light_duty.html

43. www.cleanairt.com/products_montana_system.html

44. www.cleanairt.com/products_universal.html

45. www.epa.gov/airmarkets/monitoring/pems.html

46. www.mccrometer.com

47. www.mccrometer.com/library/9811/lit_vc.htm

48. www.powerspecialties.com/dieterich_Annubar@Principle.htm

49. www.sensors-inc.com/semtechd.htm

50. www.signal-group.com

51. www.detroitdiesel.com/public/brochures/6SA303.pdf 


\section{Chapter 8 Appendix}

\subsection{Appendix A}

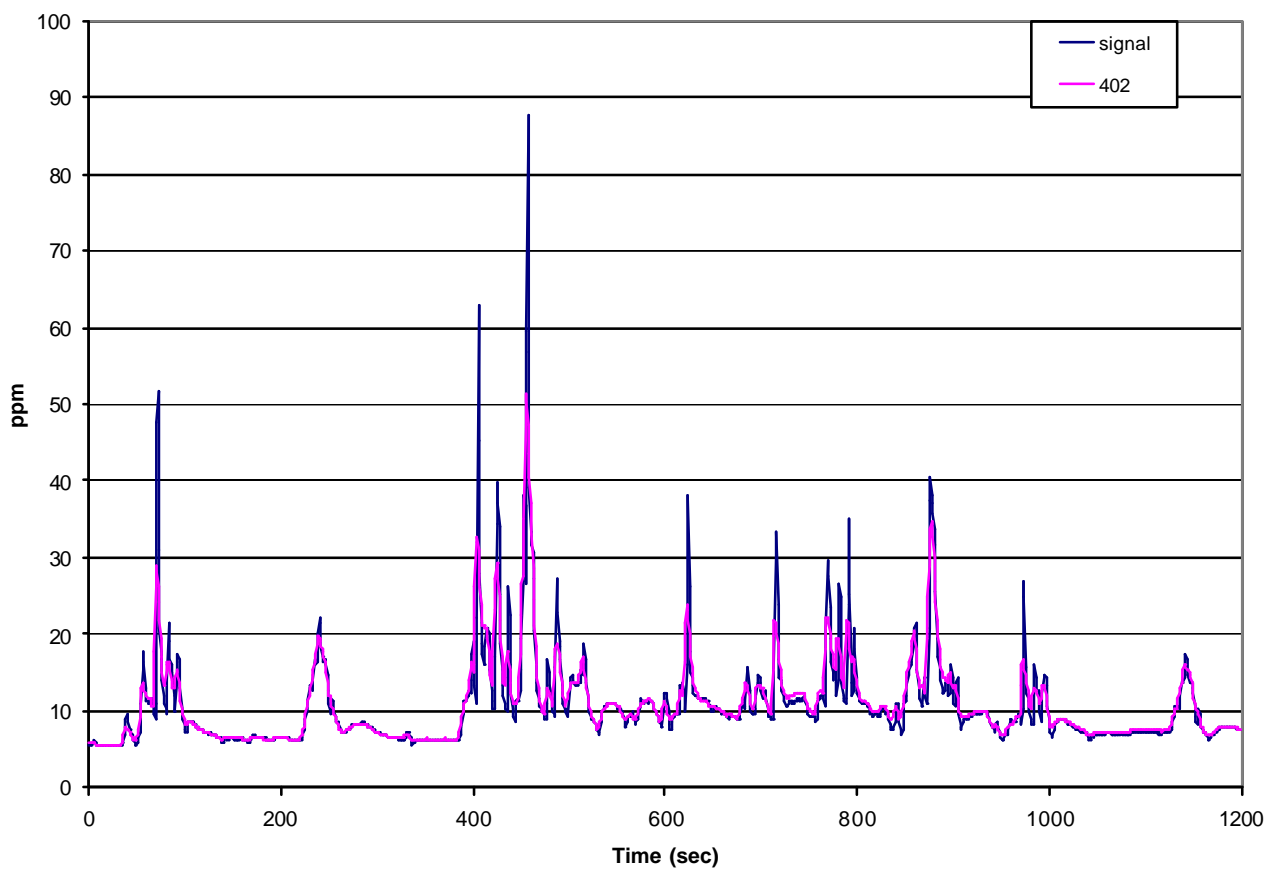

Figure 8.1 Hydrocarbon comparison of the HFID for transient FTP test-1.

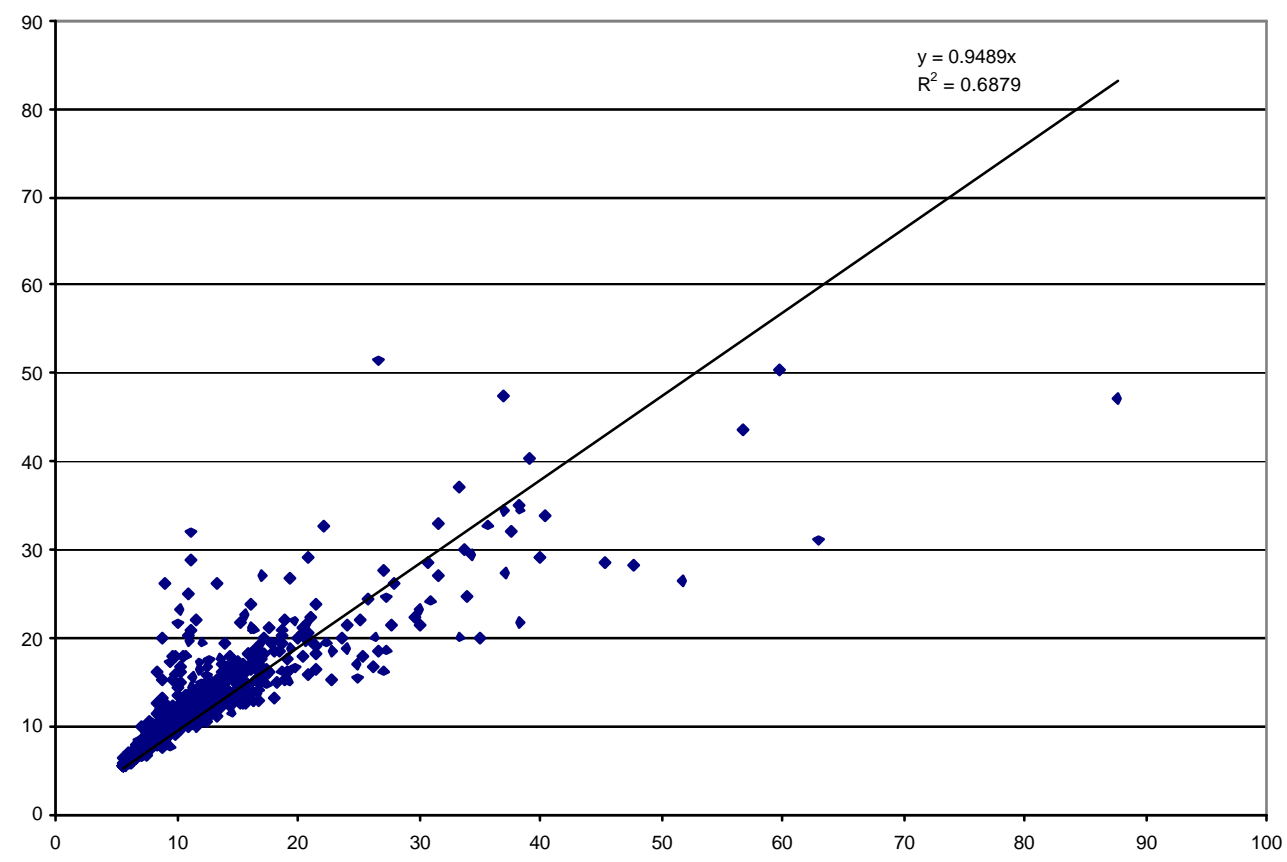

Figure 8.2 Regression analysis of the HFID analyzers for transient FTP test-1. 


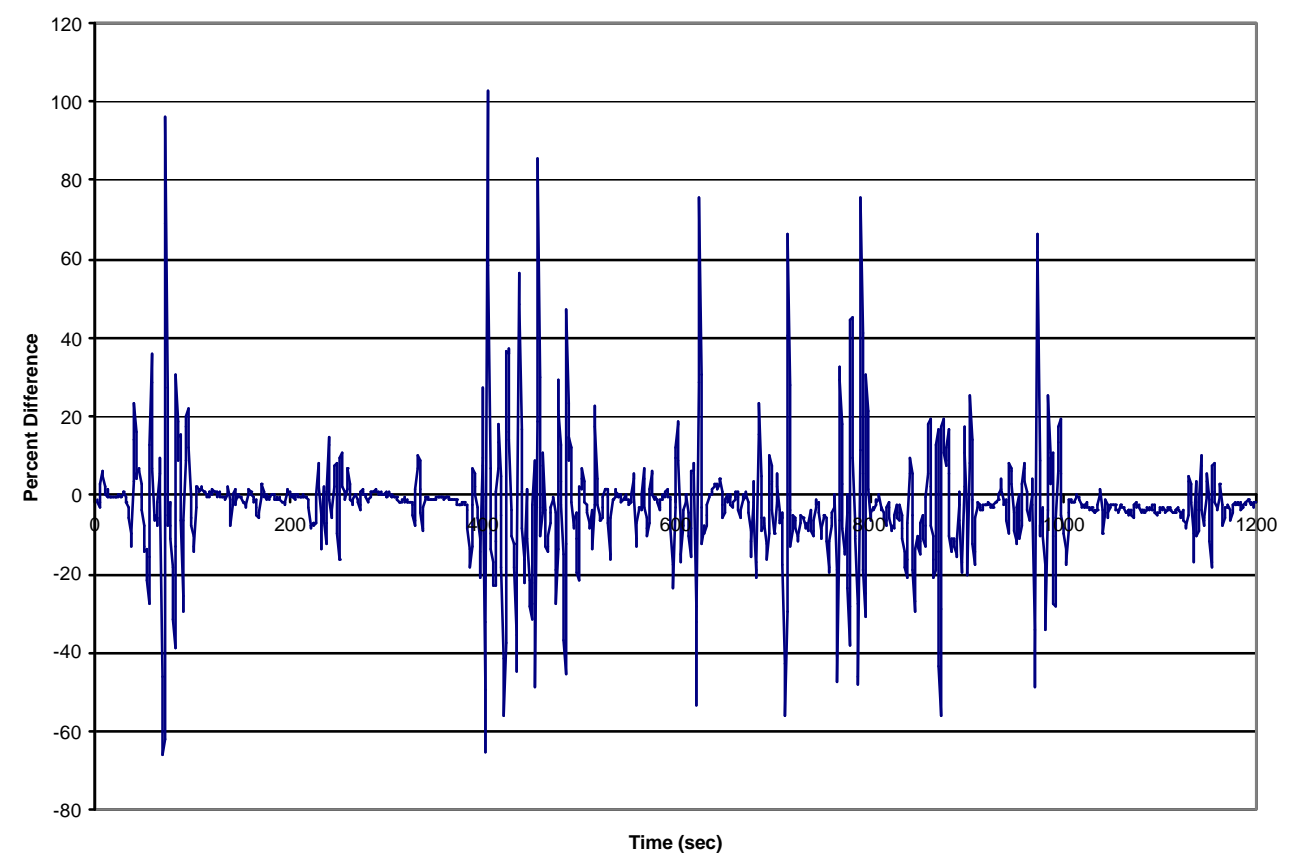

Figure 8.3 Percent difference of the HFID analyzers for transient FTP test-1.

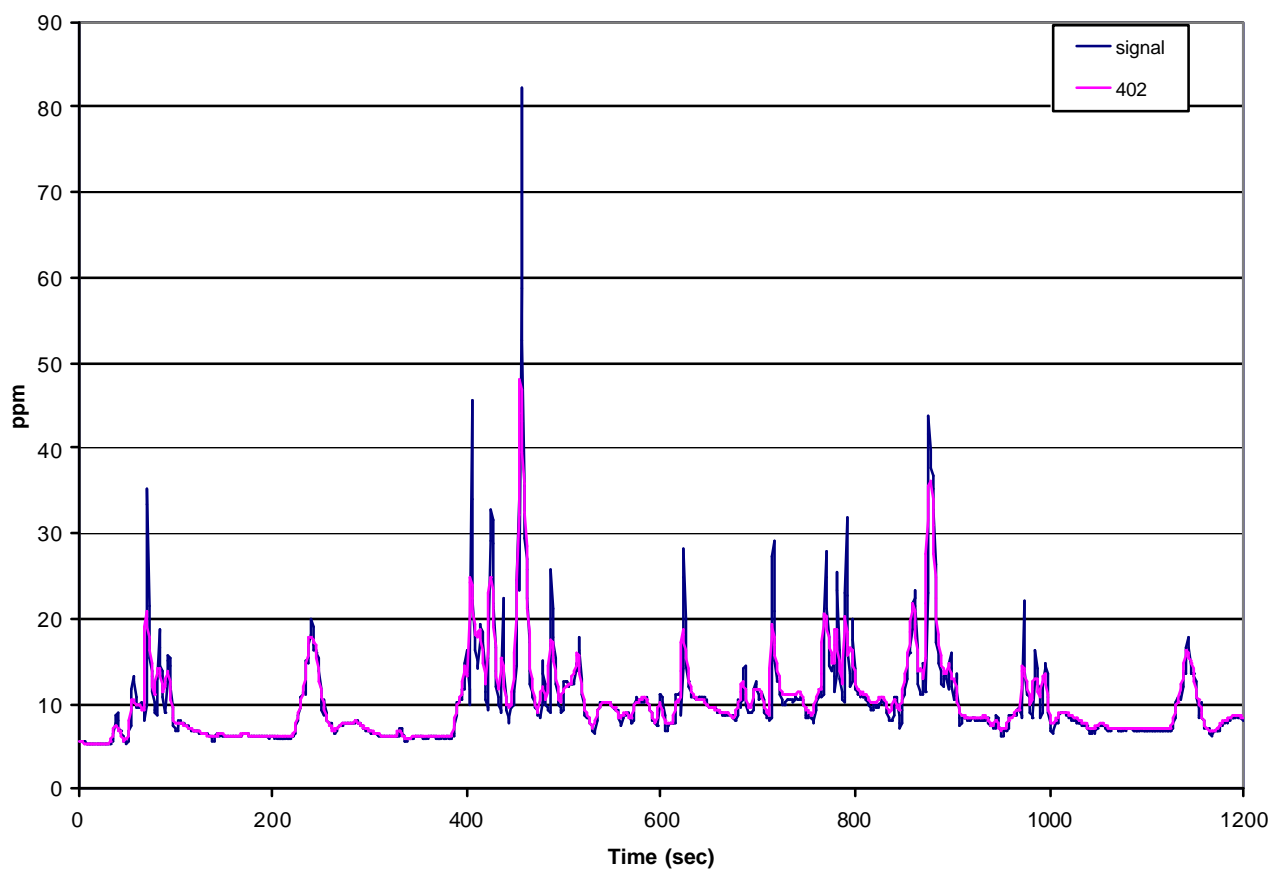

Figure 8.4 Hydrocarbon comparison of the HFID for tra nsient FTP test-2. 


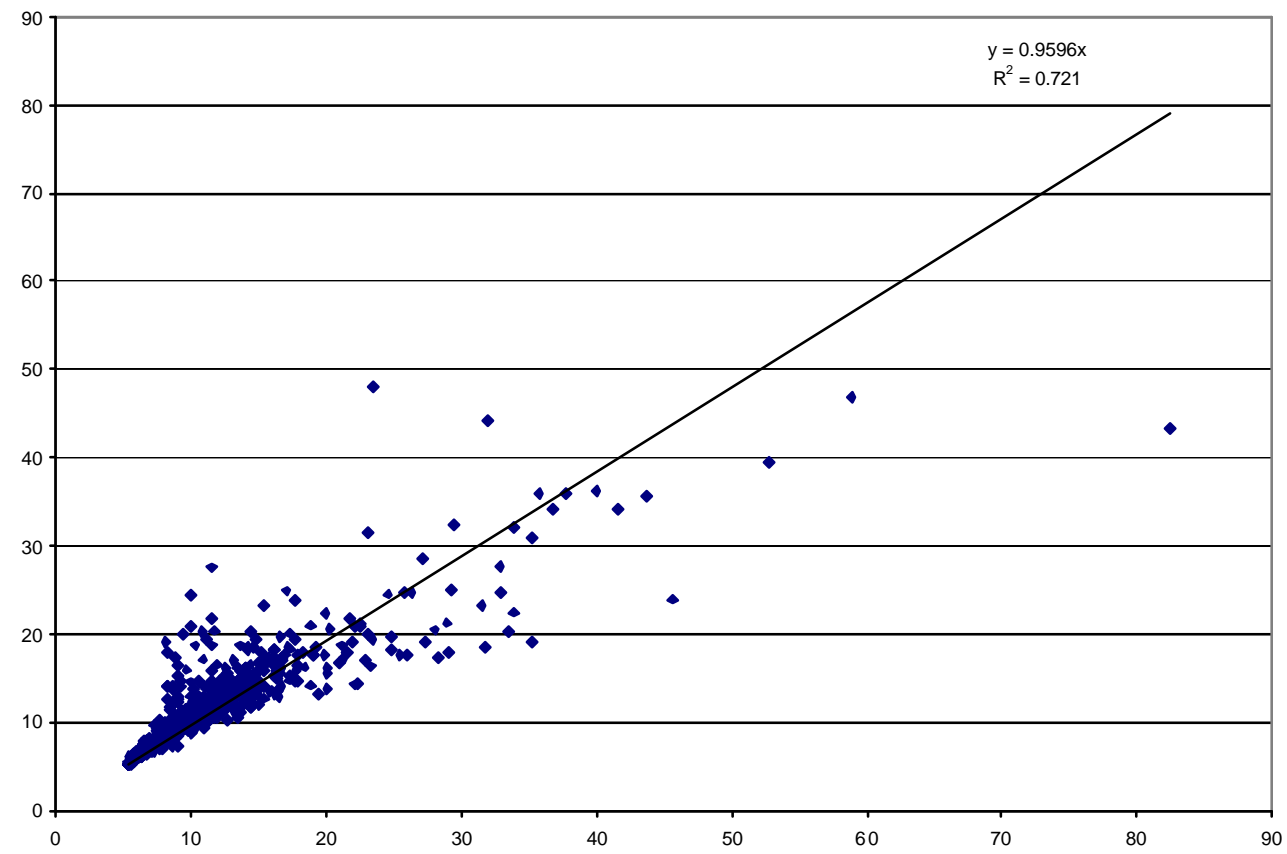

Figure 8.5 Regression analysis of the HFID analyzers for transient FTP test-2.

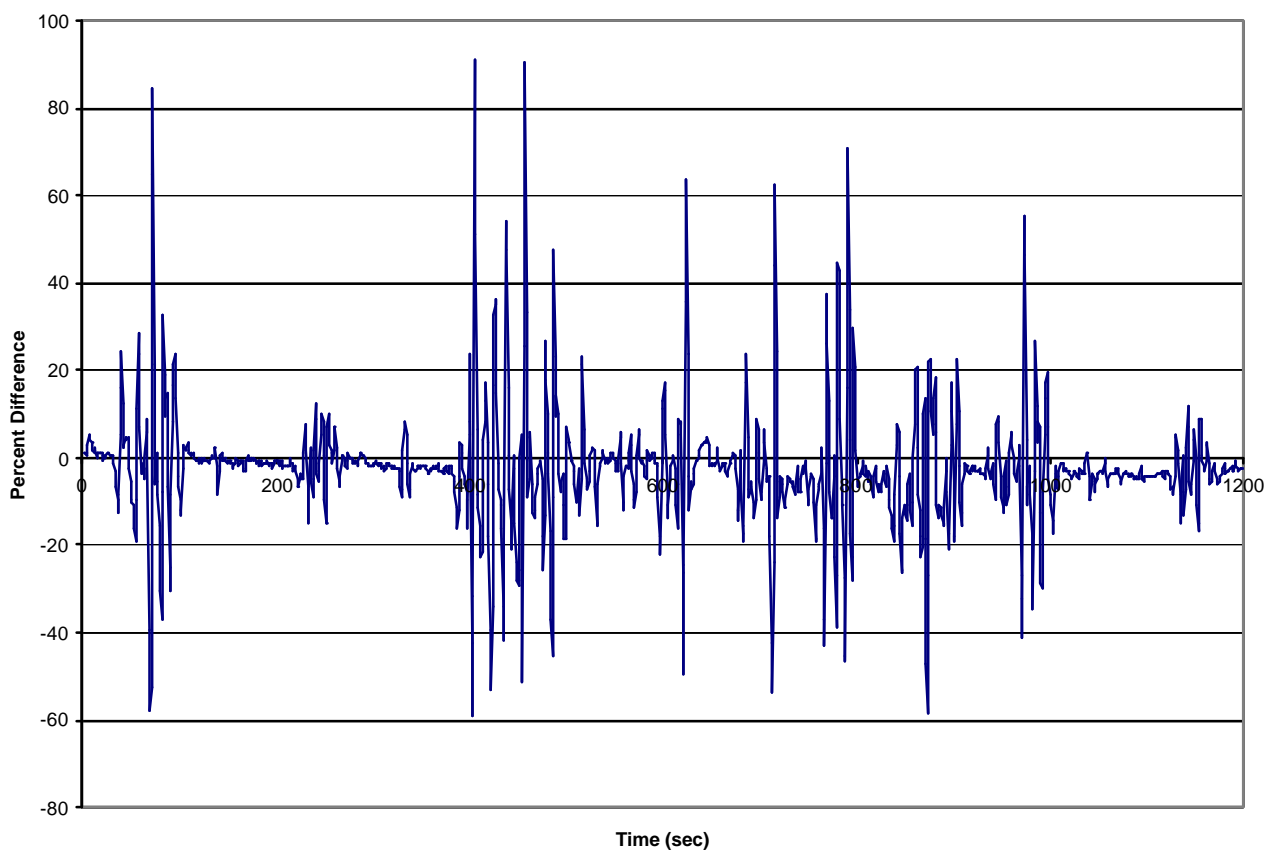

Figure 8.6 Percent difference of the HFID analyzers for transient FTP test-2. 


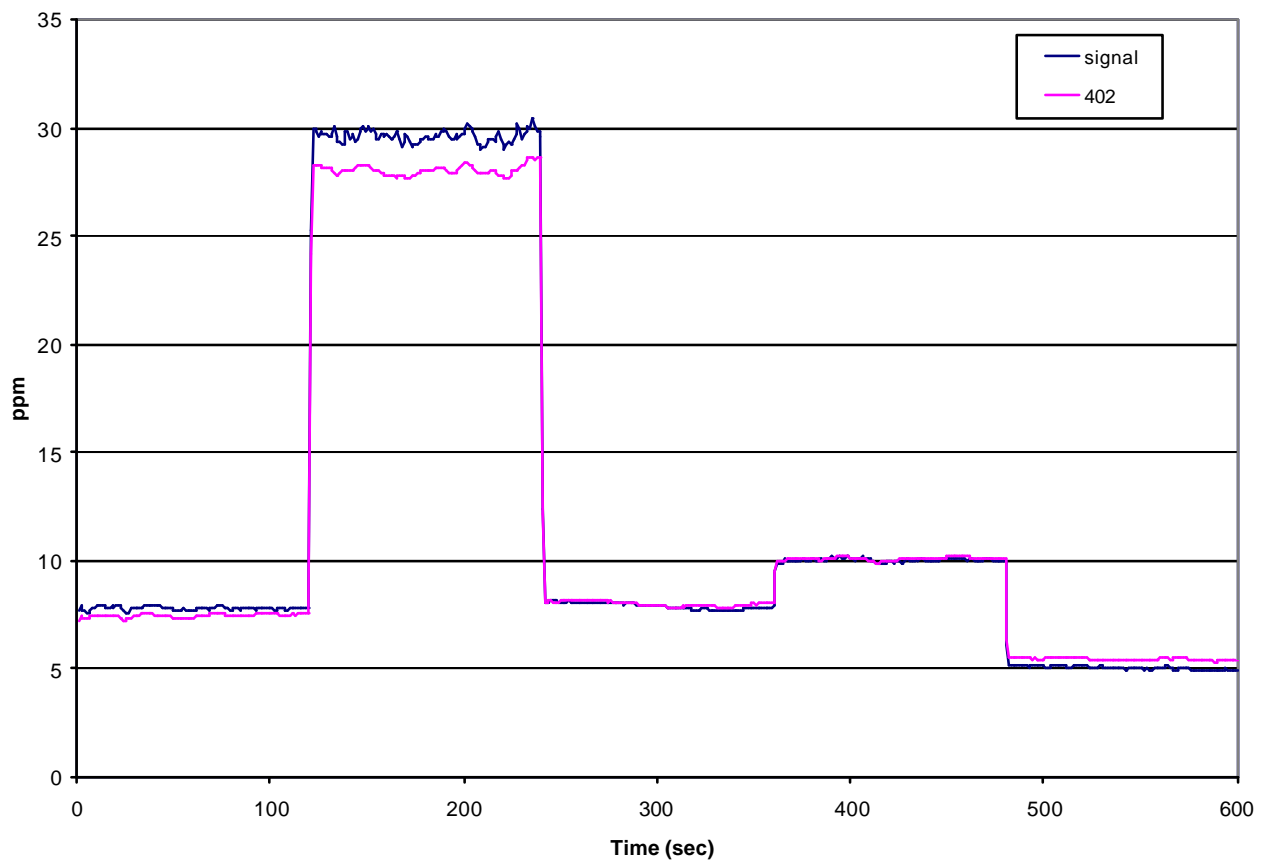

Figure 8.7 Hydrocarbon comparison of the HFID for steady state 6-mode test-1.

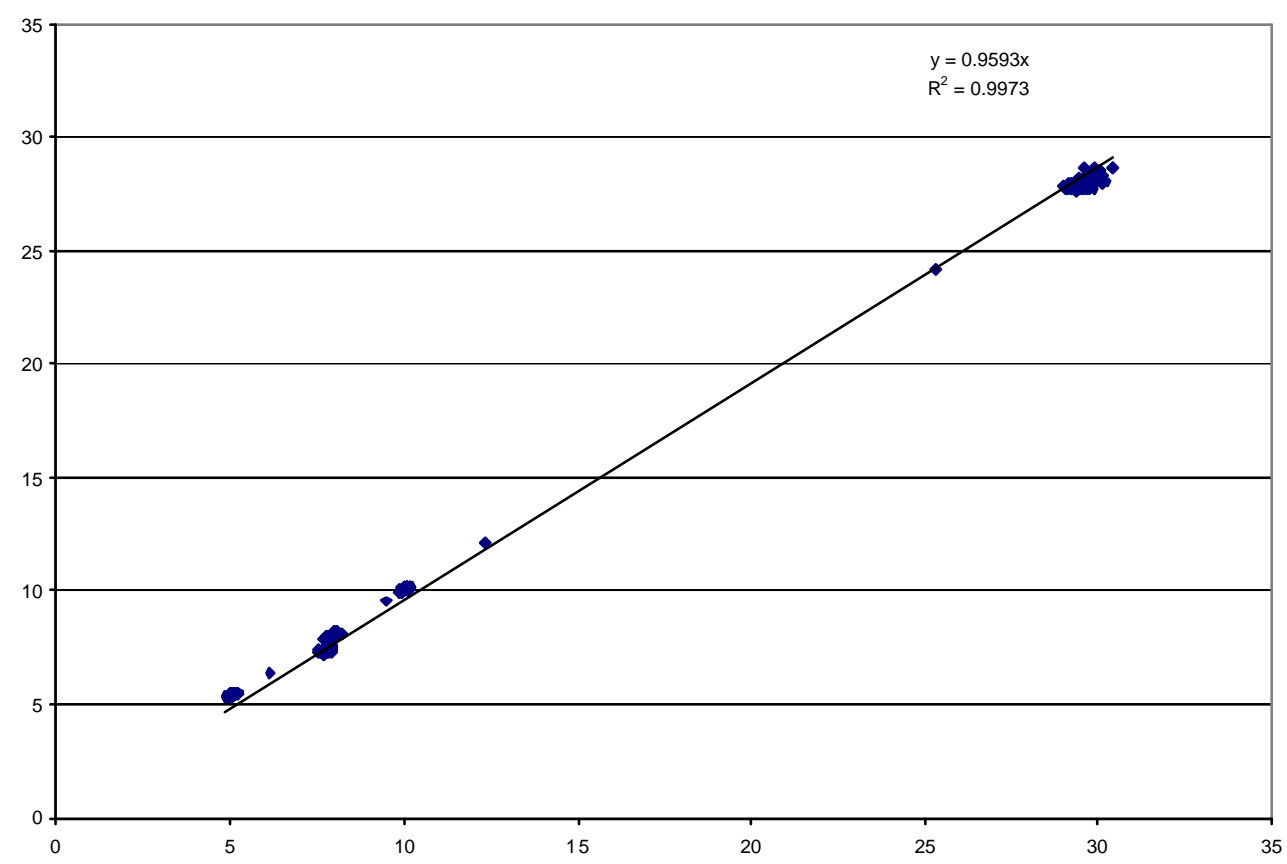

Figure 8.8 Regression analysis of the HFID for steady state 6-mode test-1. 


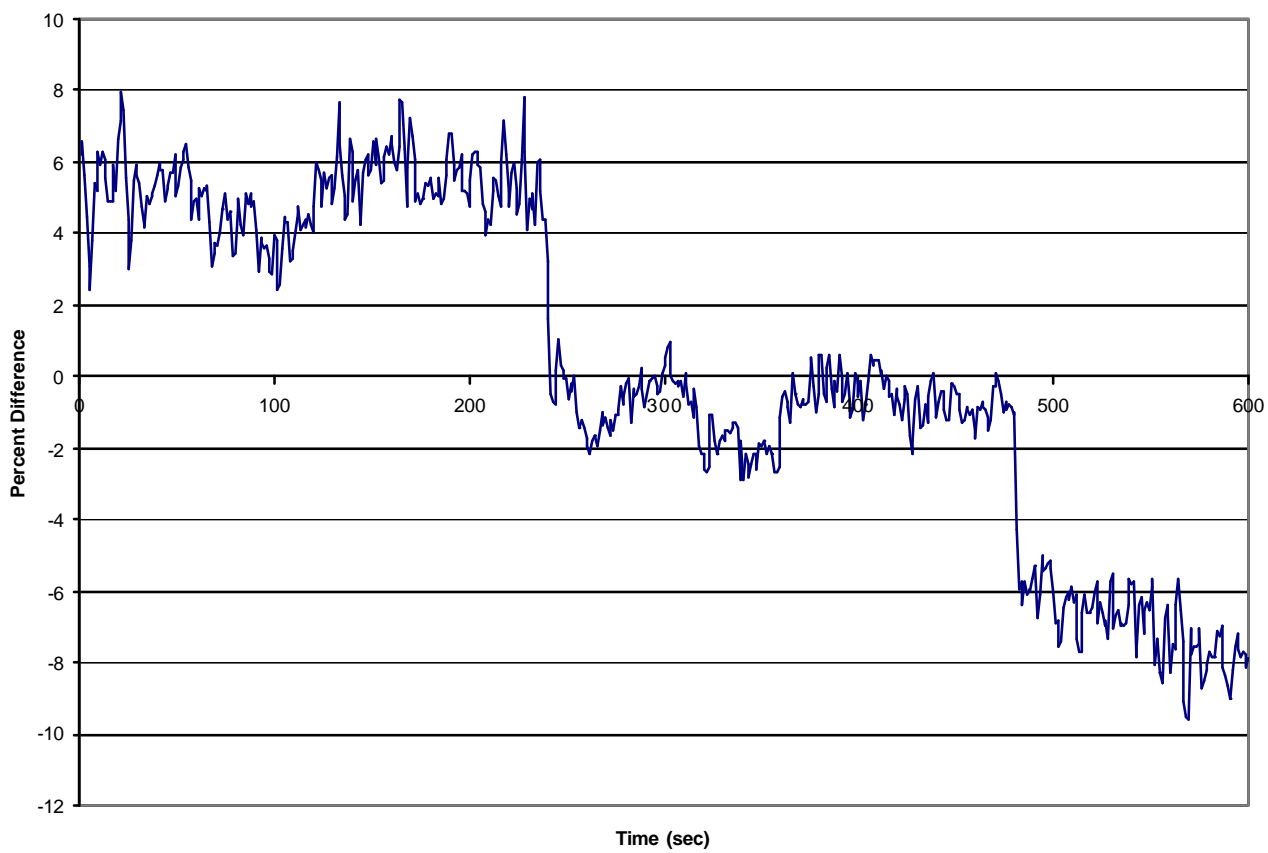

Figure 8.9 Percent difference of the HFID for steady state 6-mode test-1.

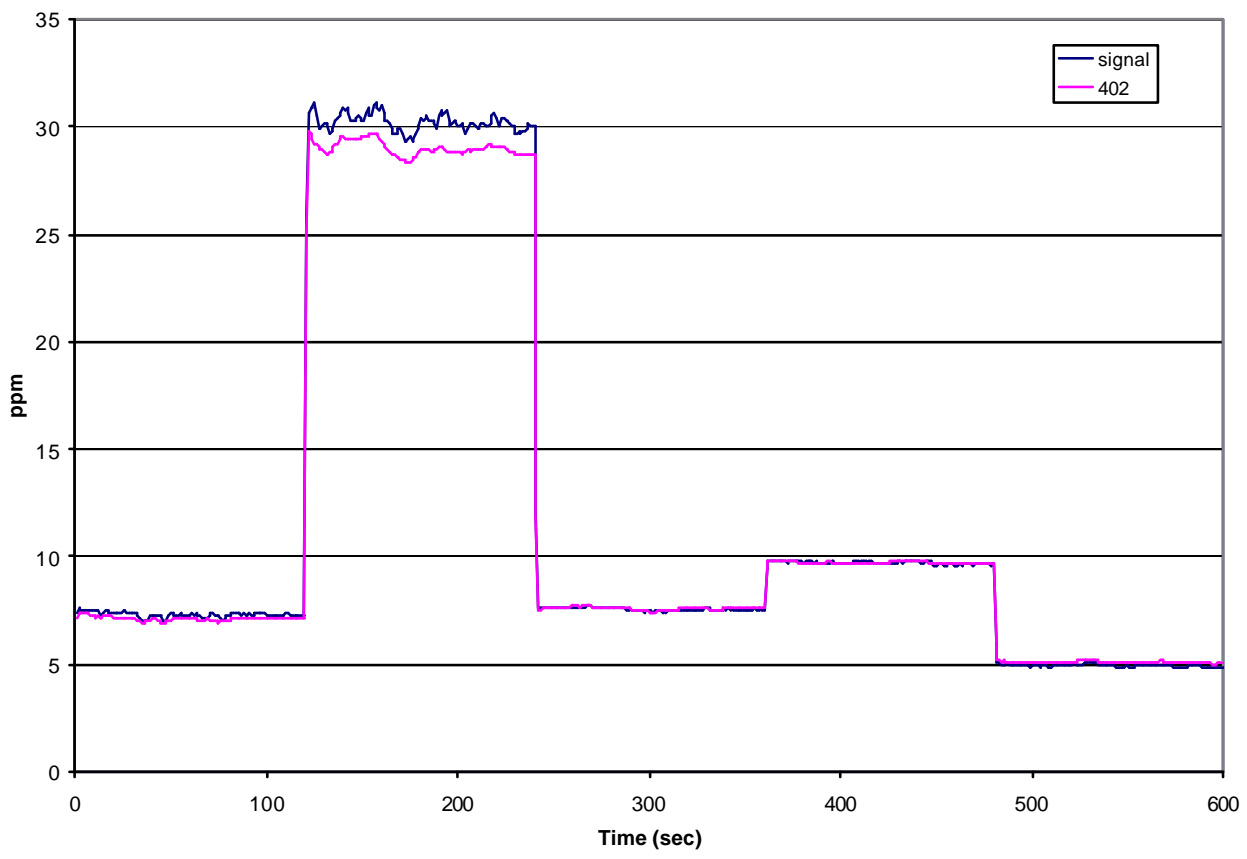

Figure 8.10 Hydrocarbon comparison of the HFID for steady state 6-mode test-2. 


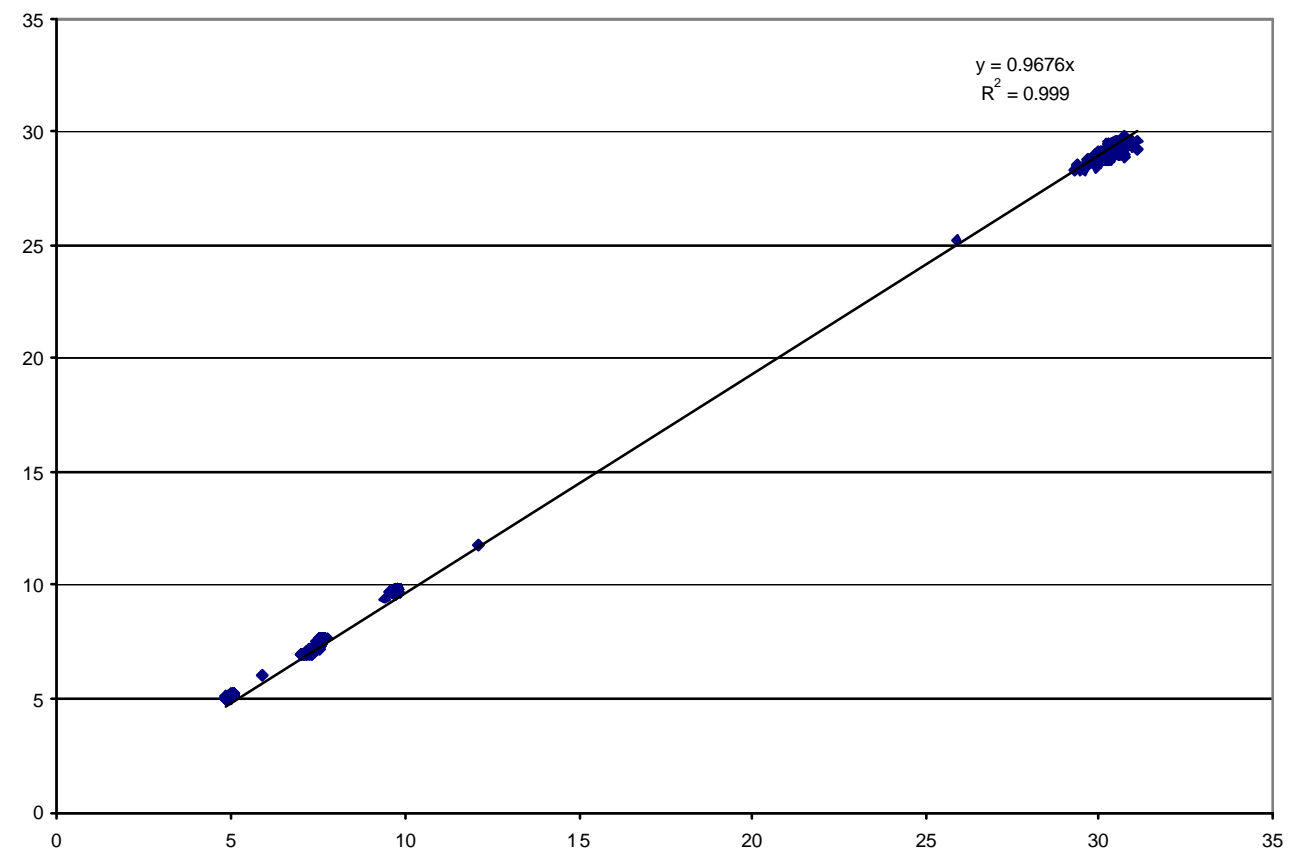

Figure 8.11 Regression analysis of the HFID for steady state 6-mode test-2.

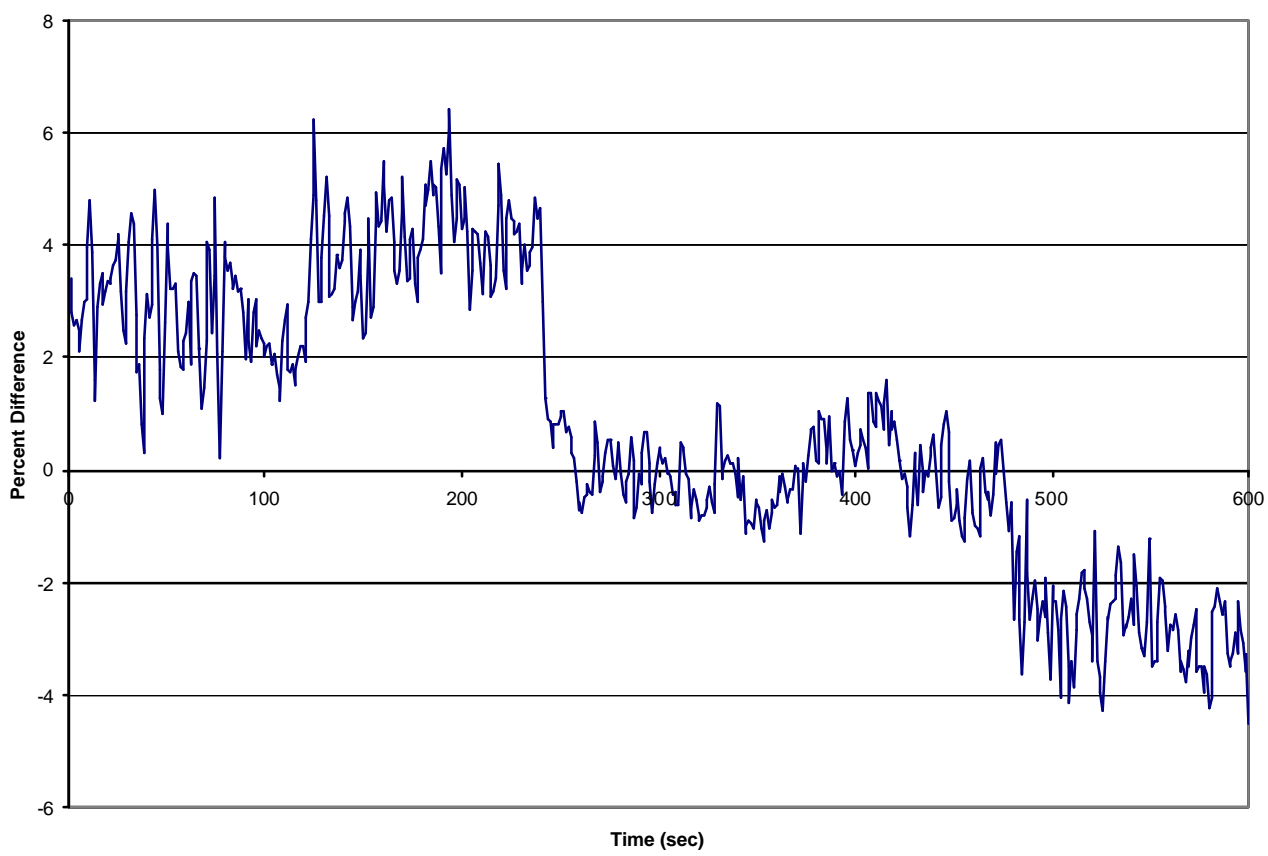

Figure 8.12 Percent difference of the HFID for steady state 6-mode test-2. 


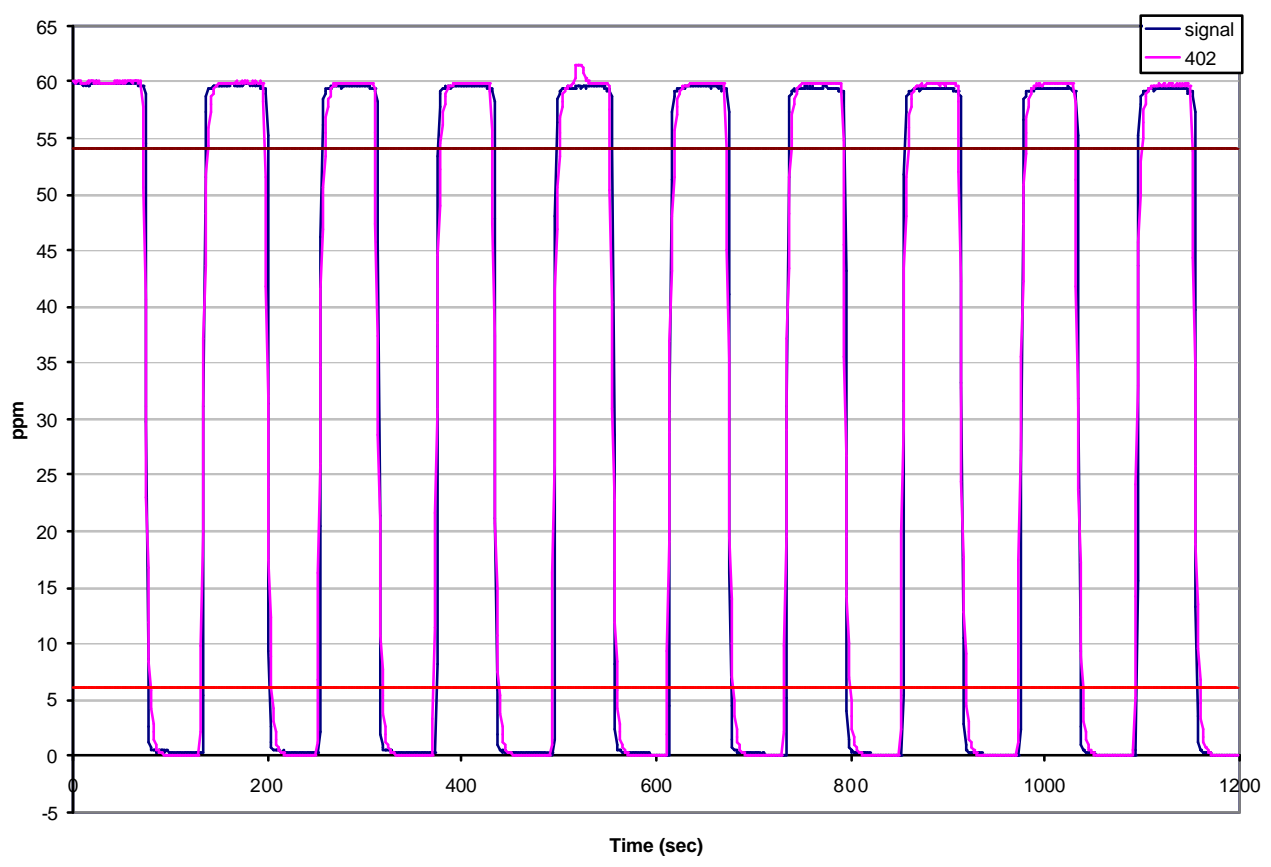

Figure 8.13 Hydrocarbon comparison of the HFID for the T90 response test.

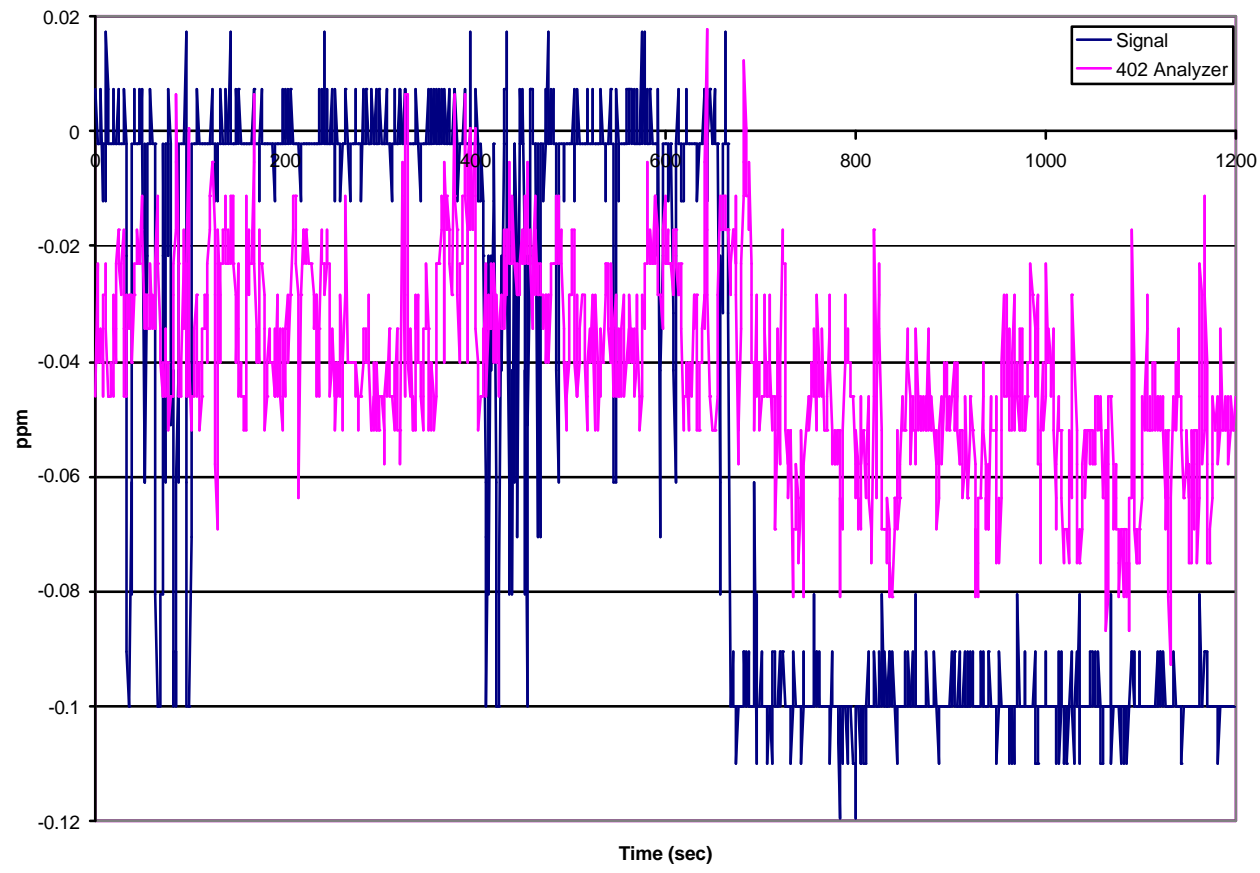

Figure 8.14 Hydrocarbon comparison of the HFID for the zero air drift test. 


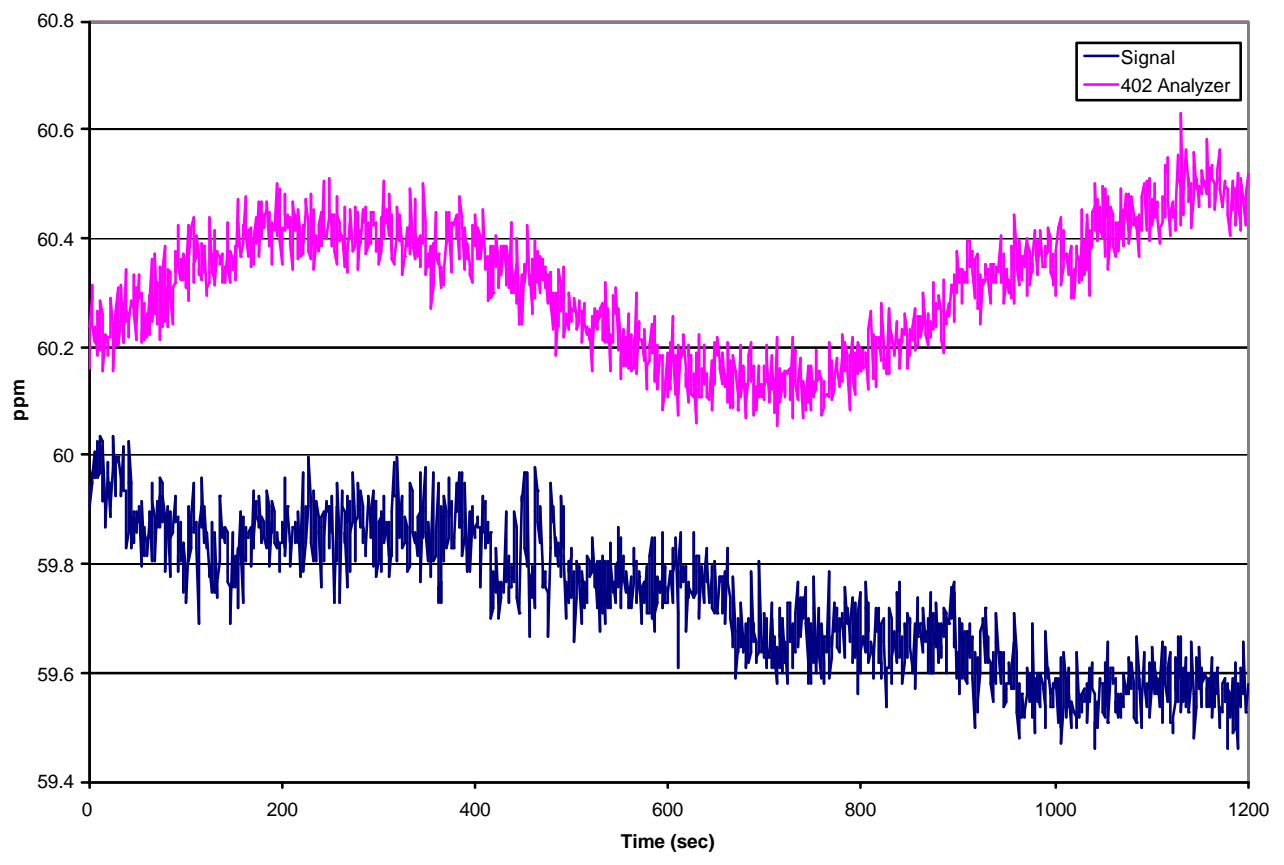

Figure 8.15 Hydrocarbon comparison of the HFID for the span gas drift test. 


\subsection{Appendix B}

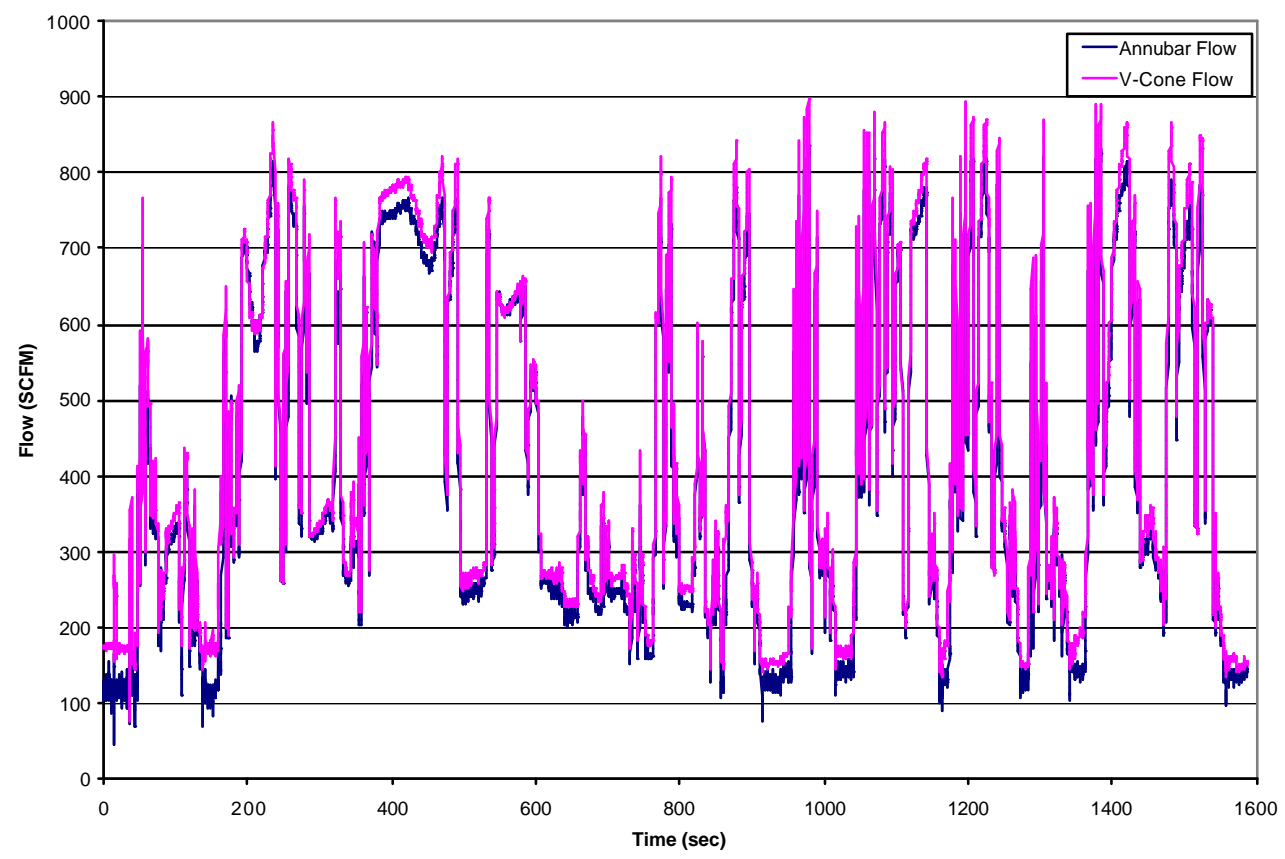

Figure 8.16 Flow rate comparison of the V-Cone and Annubar ${ }^{\circledR}$ for transient test VolvoPa1-01. 


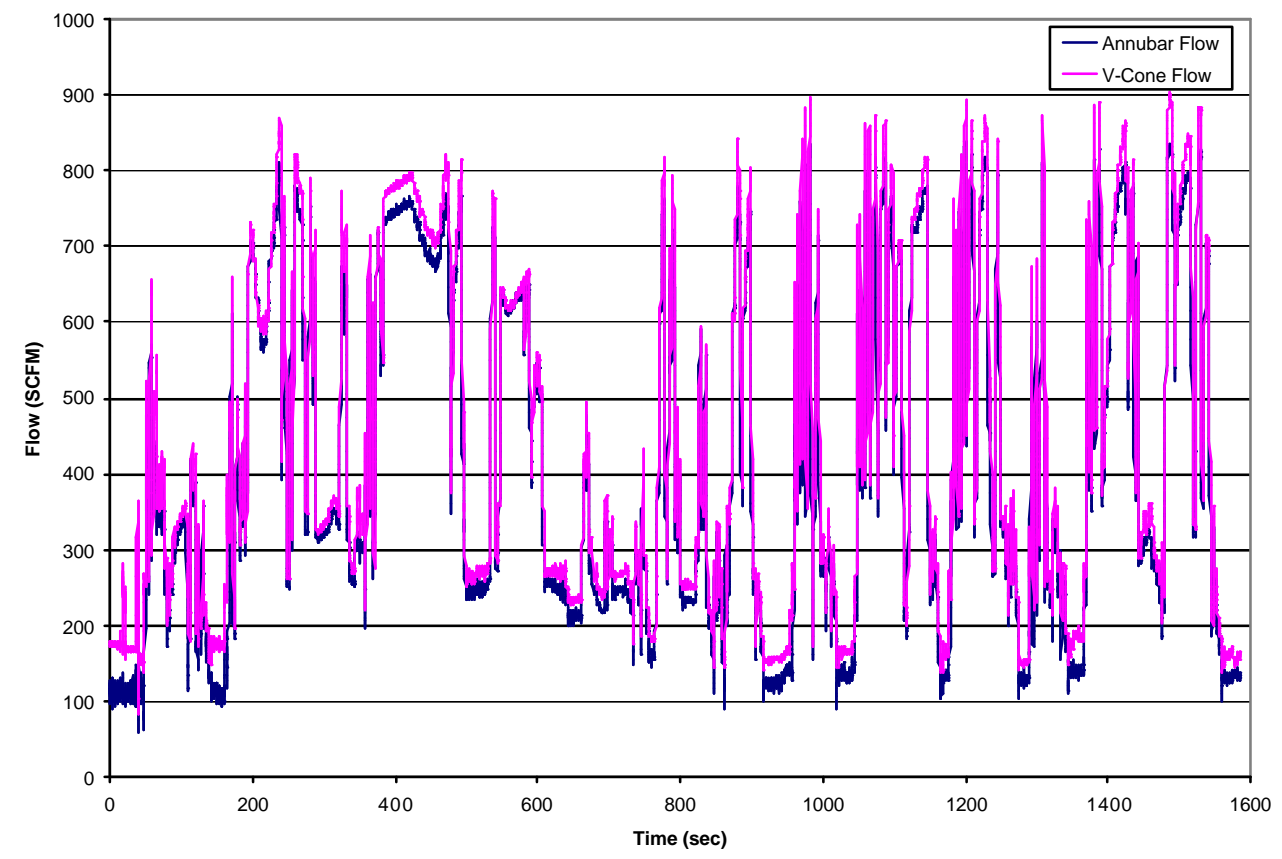

Figure 8.17 Flow rate comparison of the V-Cone and Annubar ${ }^{\circledR}$ for transient test VolvoPa1-02.

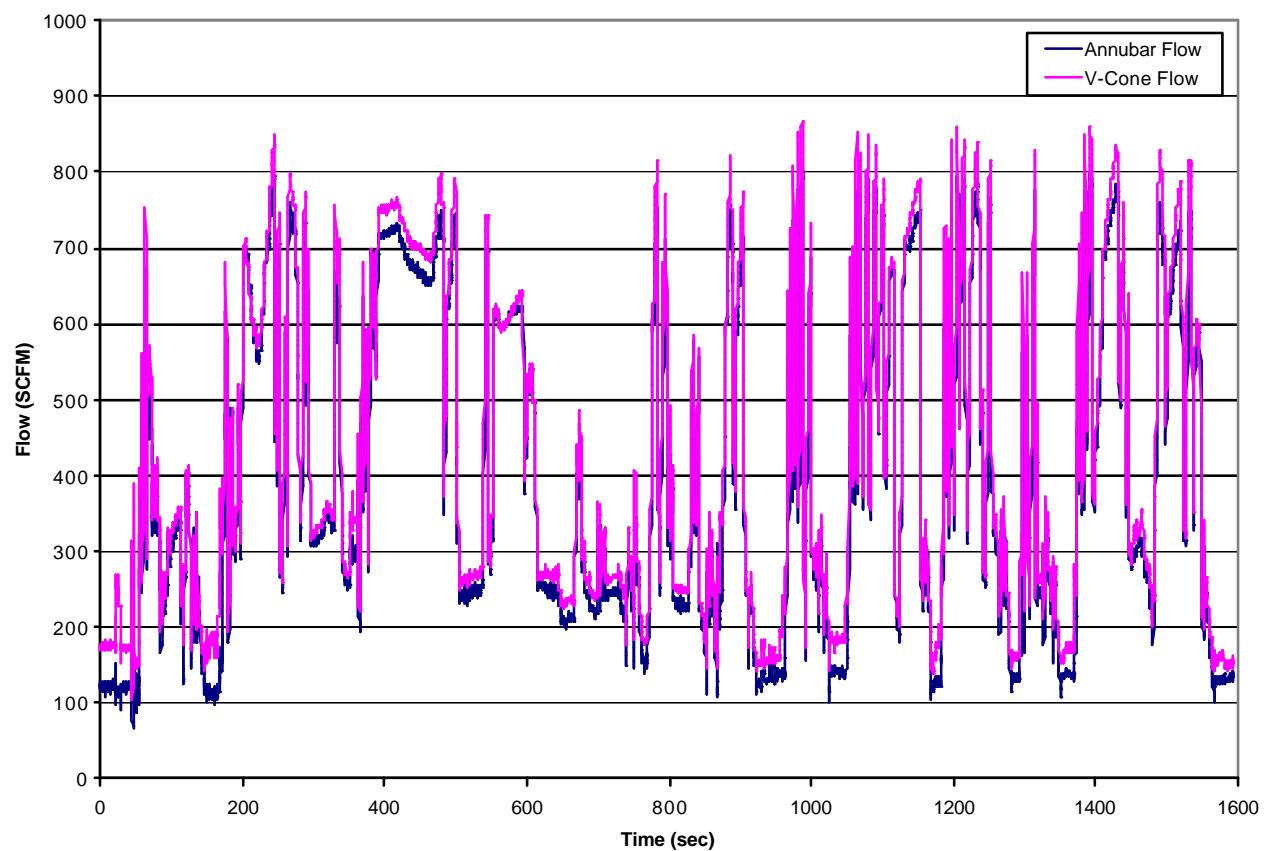

Figure 8.18 Flow rate comparison of the V-Cone and Annubar ${ }^{\circledR}$ for transient test VolvoPa1-03. 


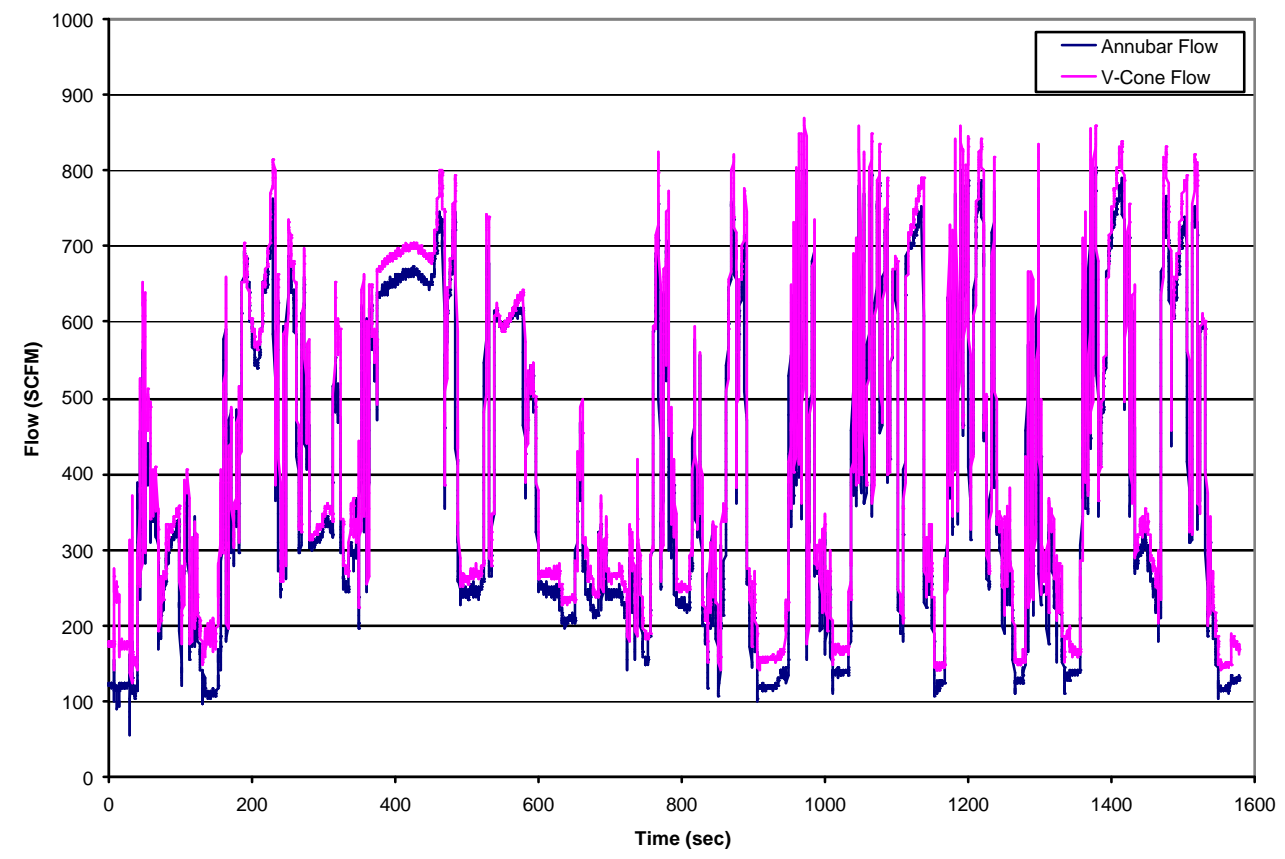

Figure 8.19 Flow rate comparison of the V-Cone and Annubar ${ }^{\circledR}$ for transient test VolvoPa1-04.

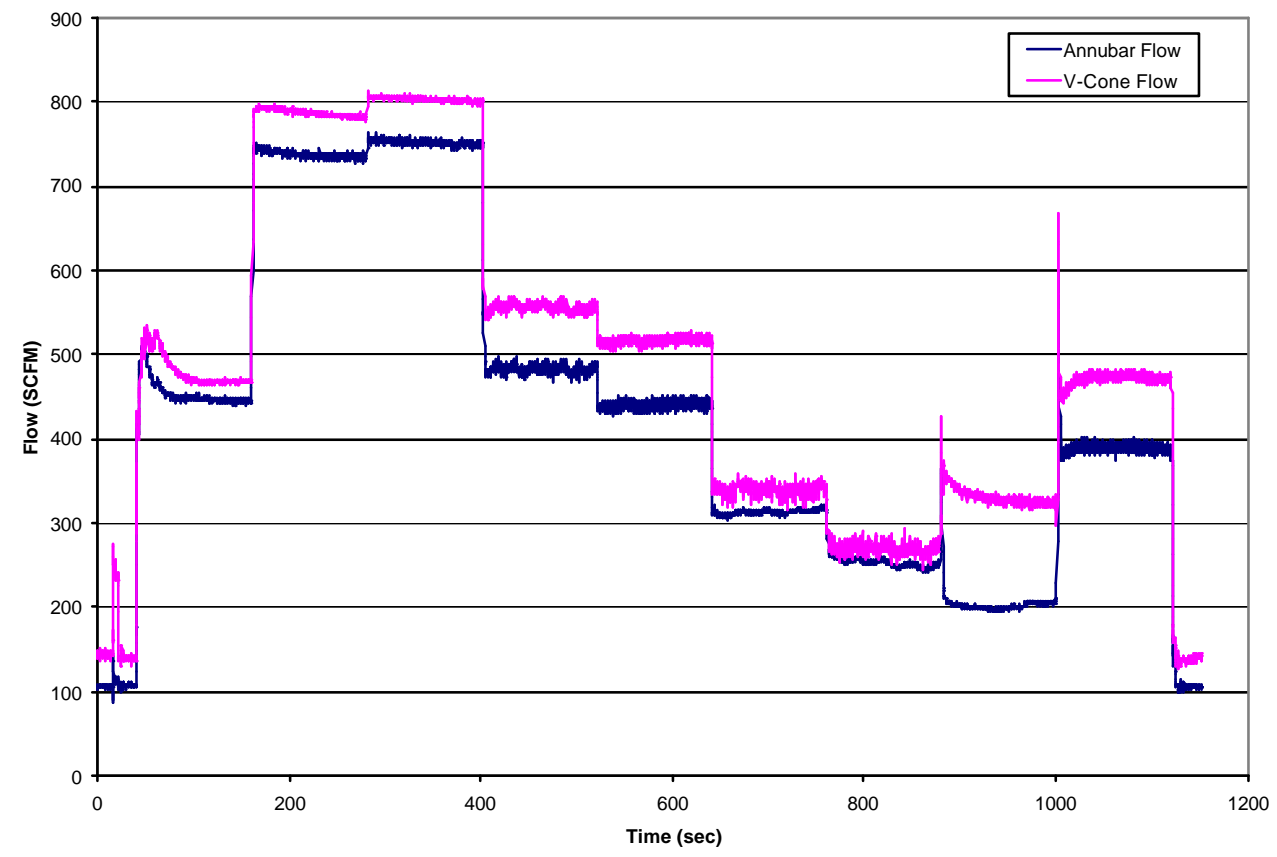

Figure 8.20 Flow rate comparison of the V-Cone and Annubar ${ }^{\circledR}$ for transient test VolvoSS2-01. 


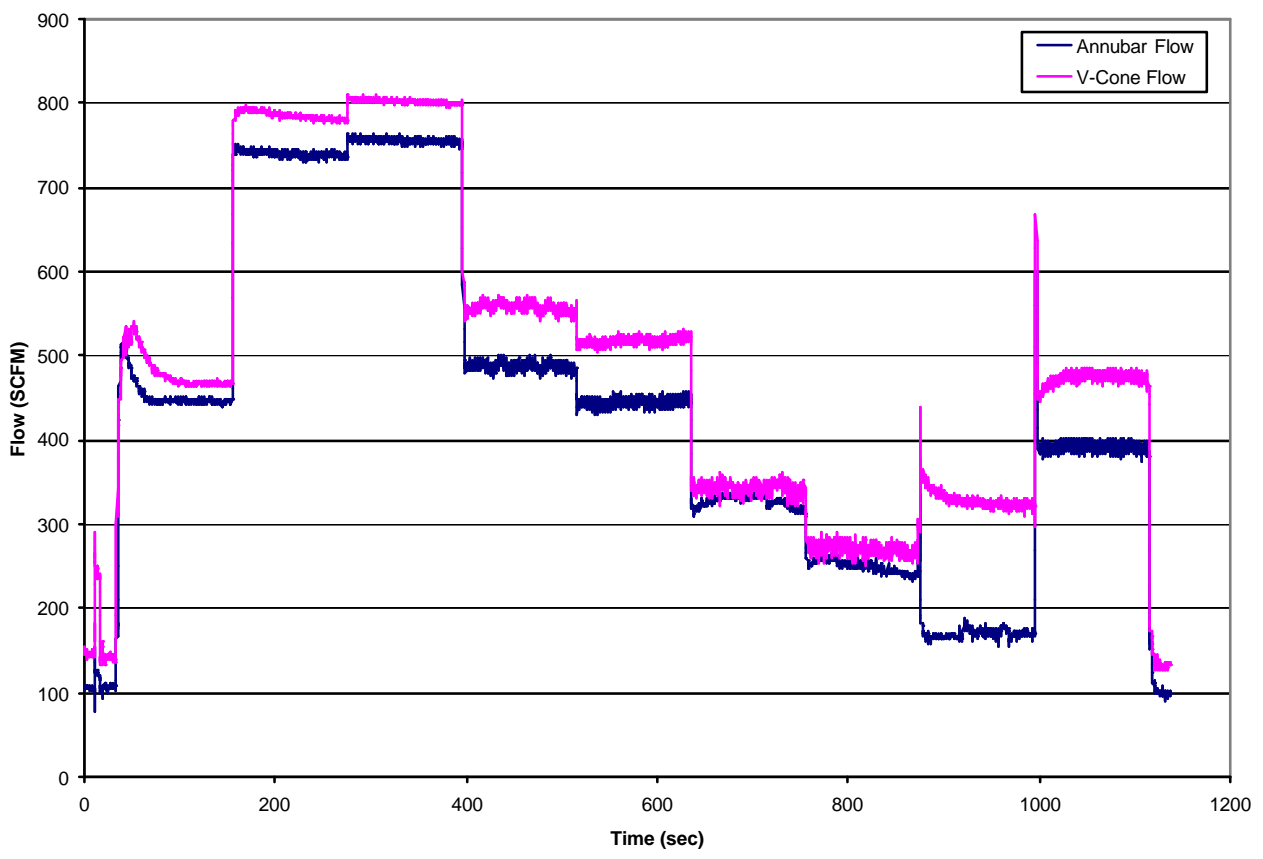

Figure 8.21 Flow rate comparison of the V-Cone and Annubar ${ }^{\circledR}$ for transient test VolvoSS2-02.

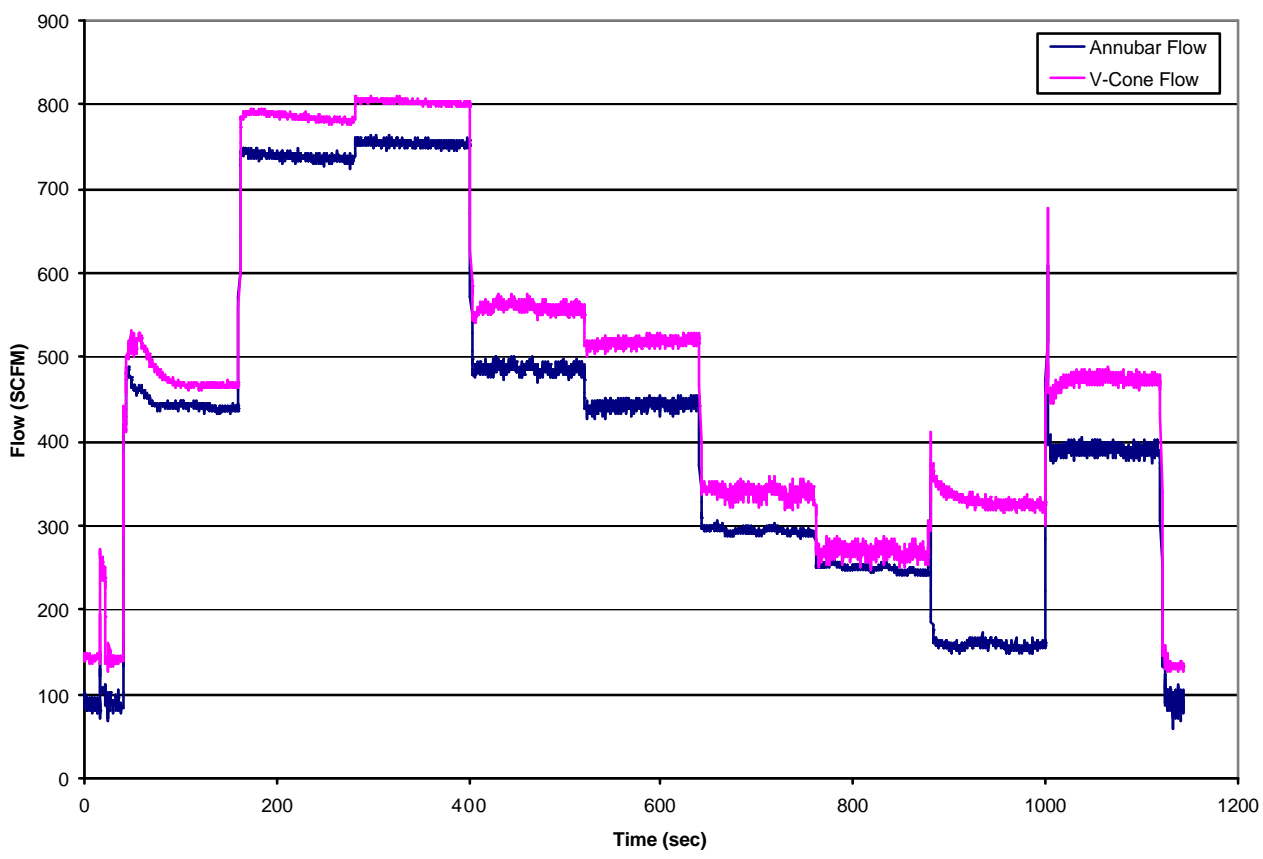

Figure 8.22 Flow rate comparison of the V-Cone and Annubar ${ }^{\circledR}$ for transient test VolvoSS2-03. 


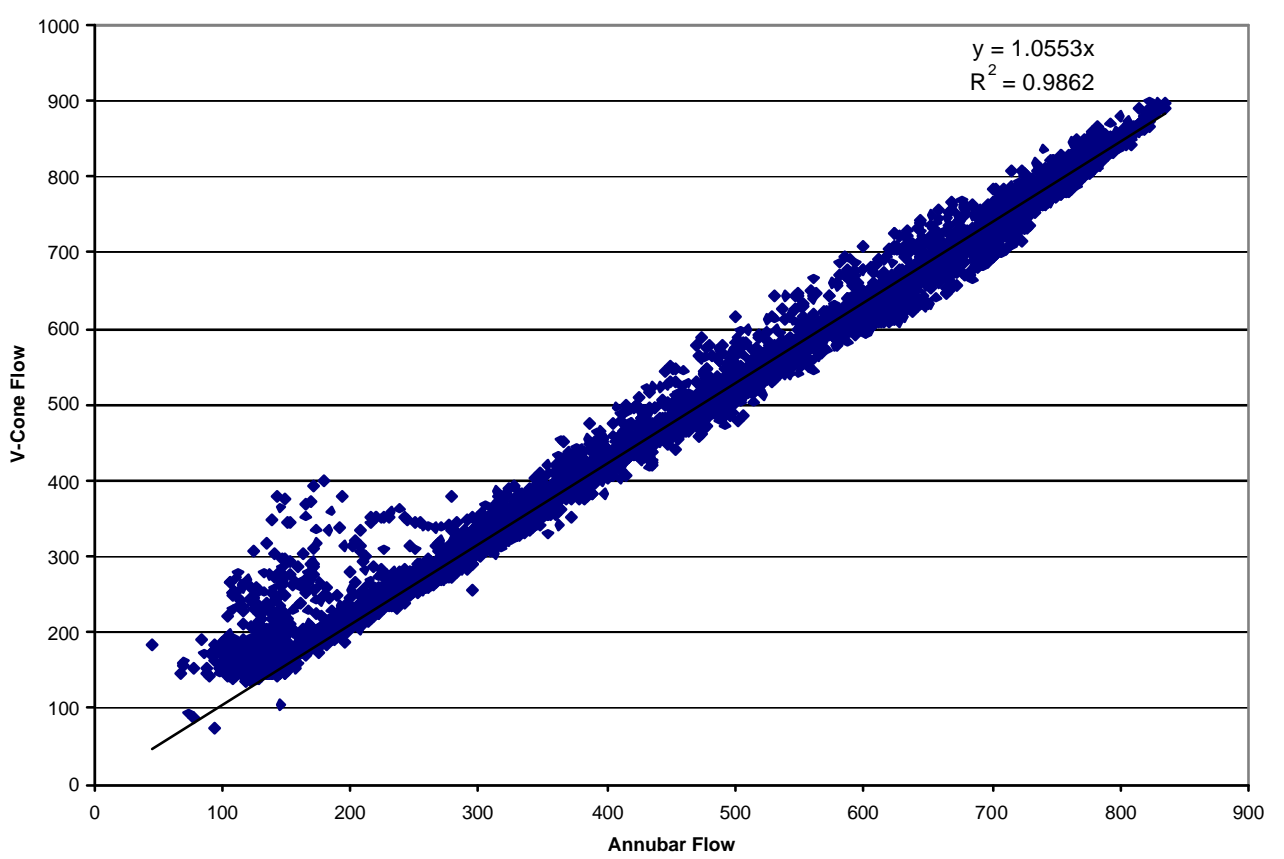

Figure 8.23 Flow rate regression analysis for the V-Cone and Annubar ${ }^{\circledR}$ for transient test VolvoPA1-01.

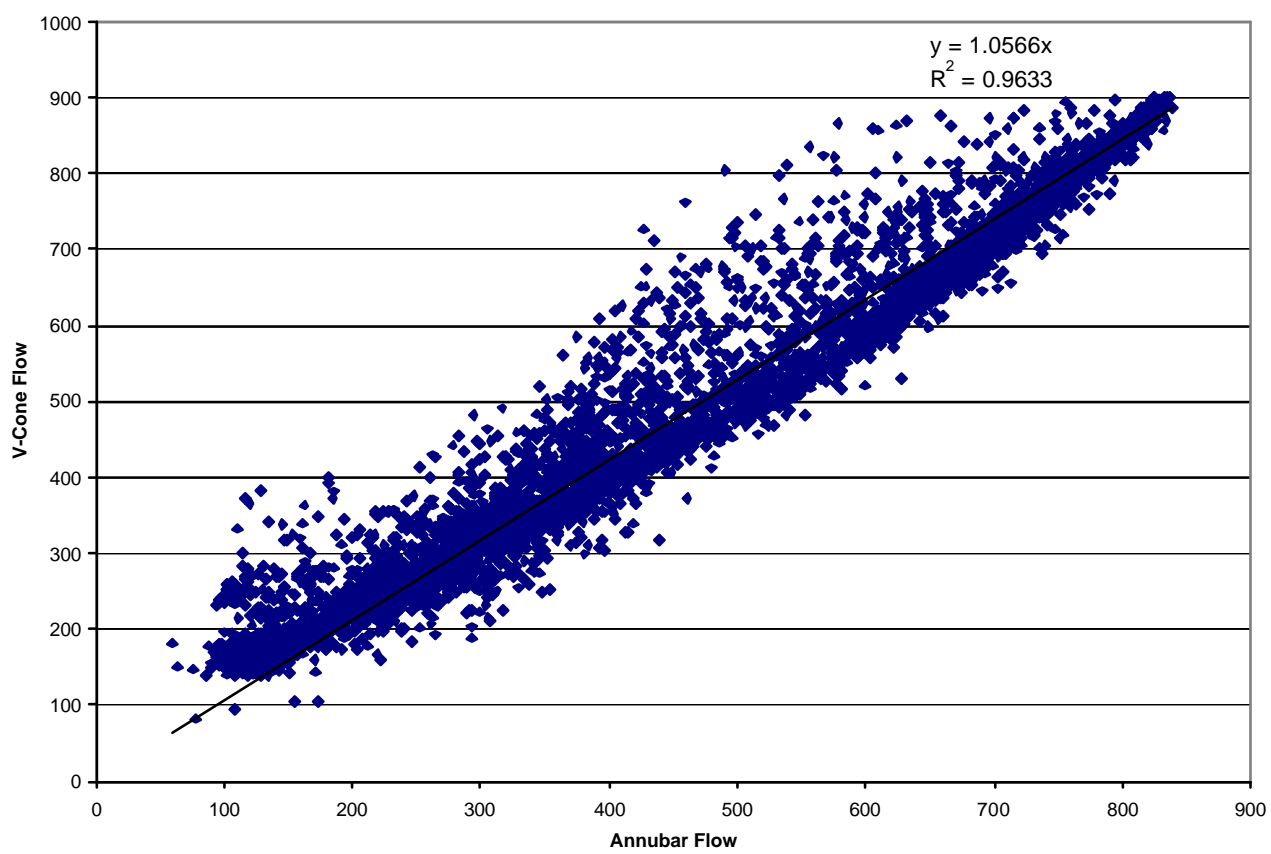

Figure 8.24 Flow rate regression analysis for the V-Cone and Annubar ${ }^{\circledR}$ for transient test VolvoPA1-02. 


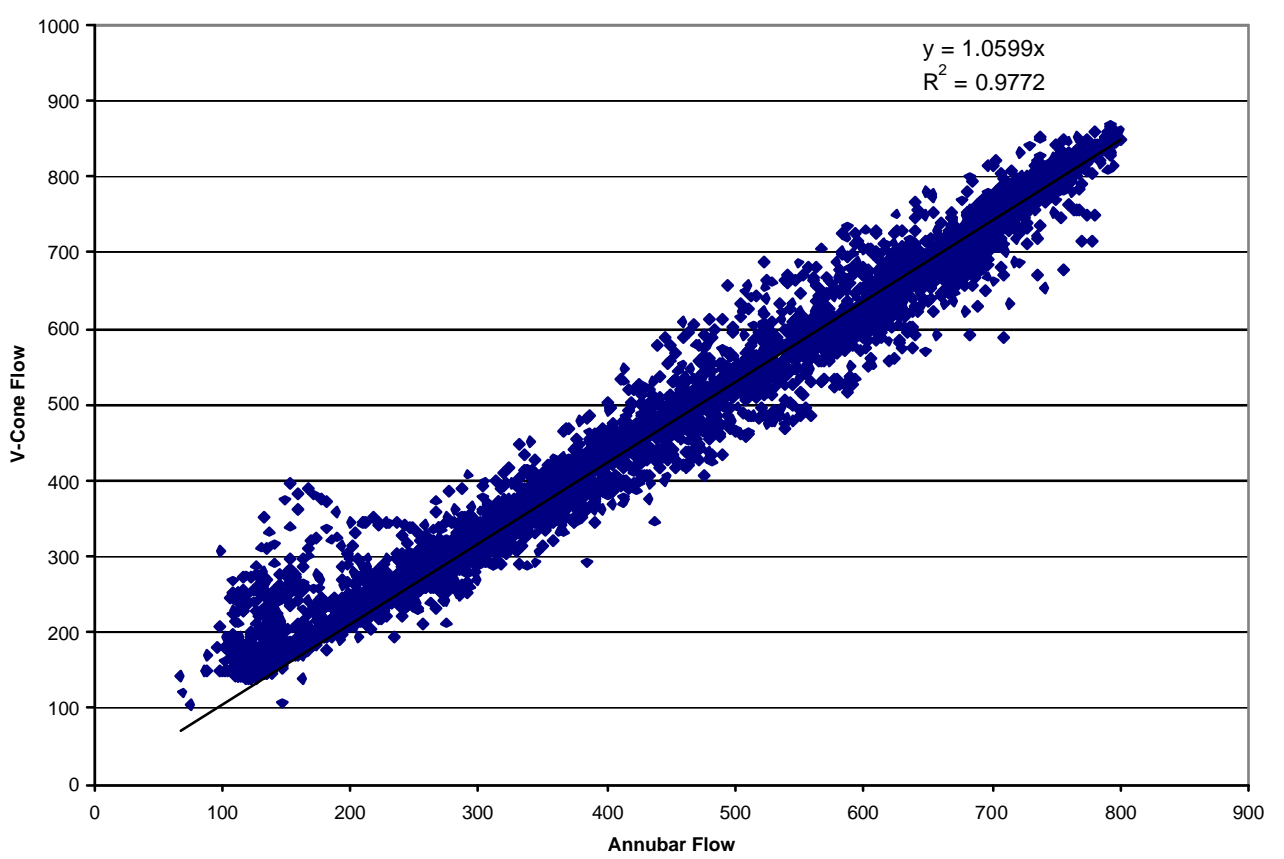

Figure 8.25 Flow rate regression analysis for the V-Cone and Annubar ${ }^{\circledR}$ for transient test VolvoPA1-03.

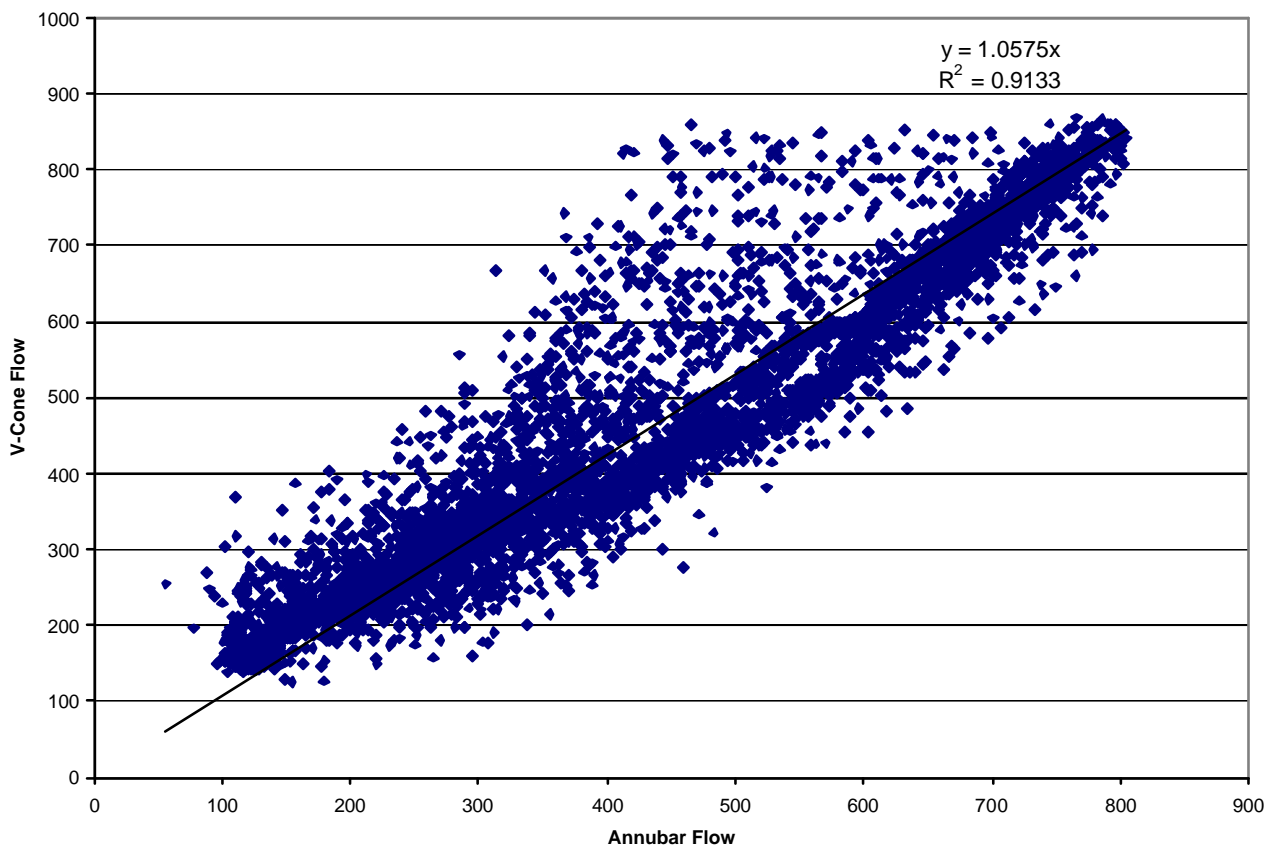

Figure 8.26 Flow rate regression analysis for the V-Cone and Annubar ${ }^{\circledR}$ for transient test VolvoPA1-04. 


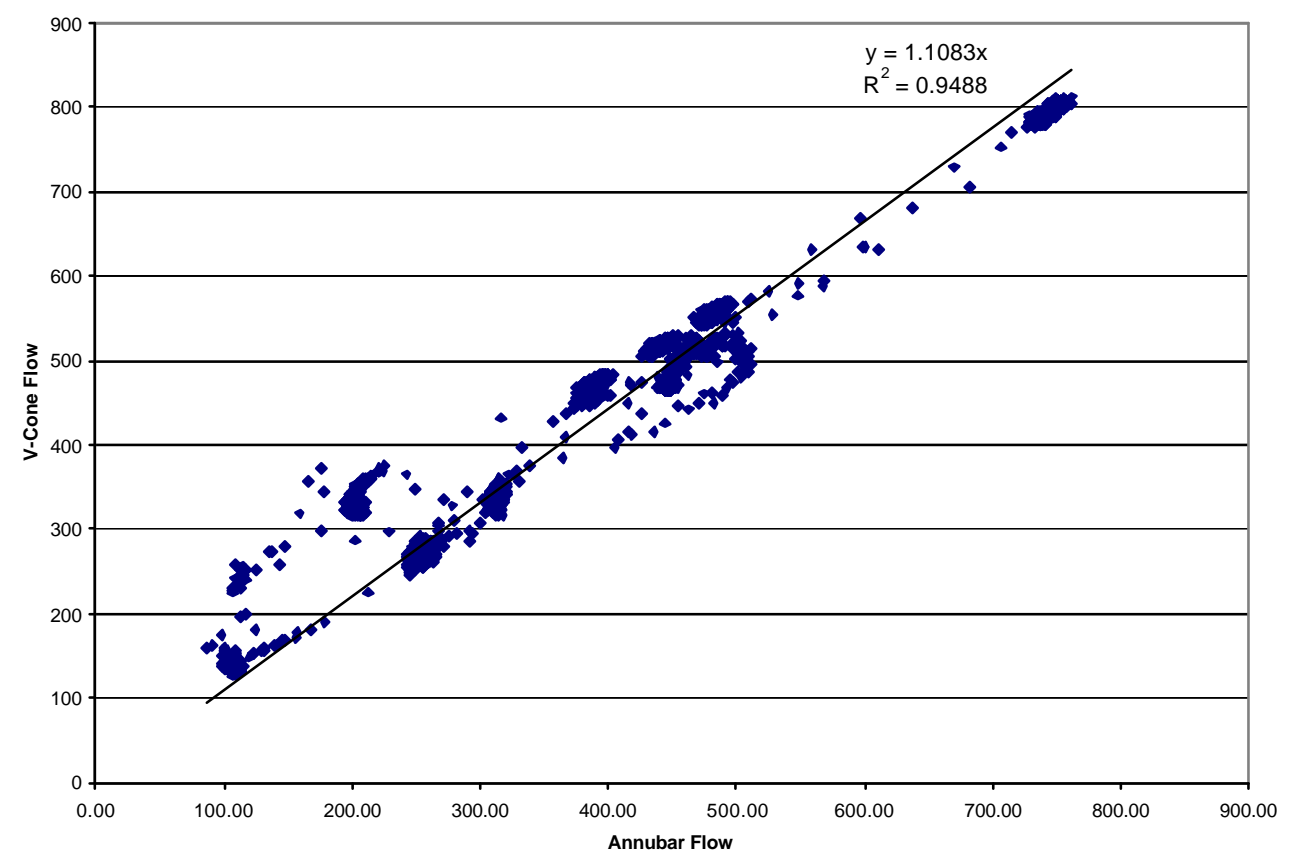

Figure 8.27 Flow rate regression analysis for the V-Cone and Annubar ${ }^{\circledR}$ for transient test VolvoSS2-01.

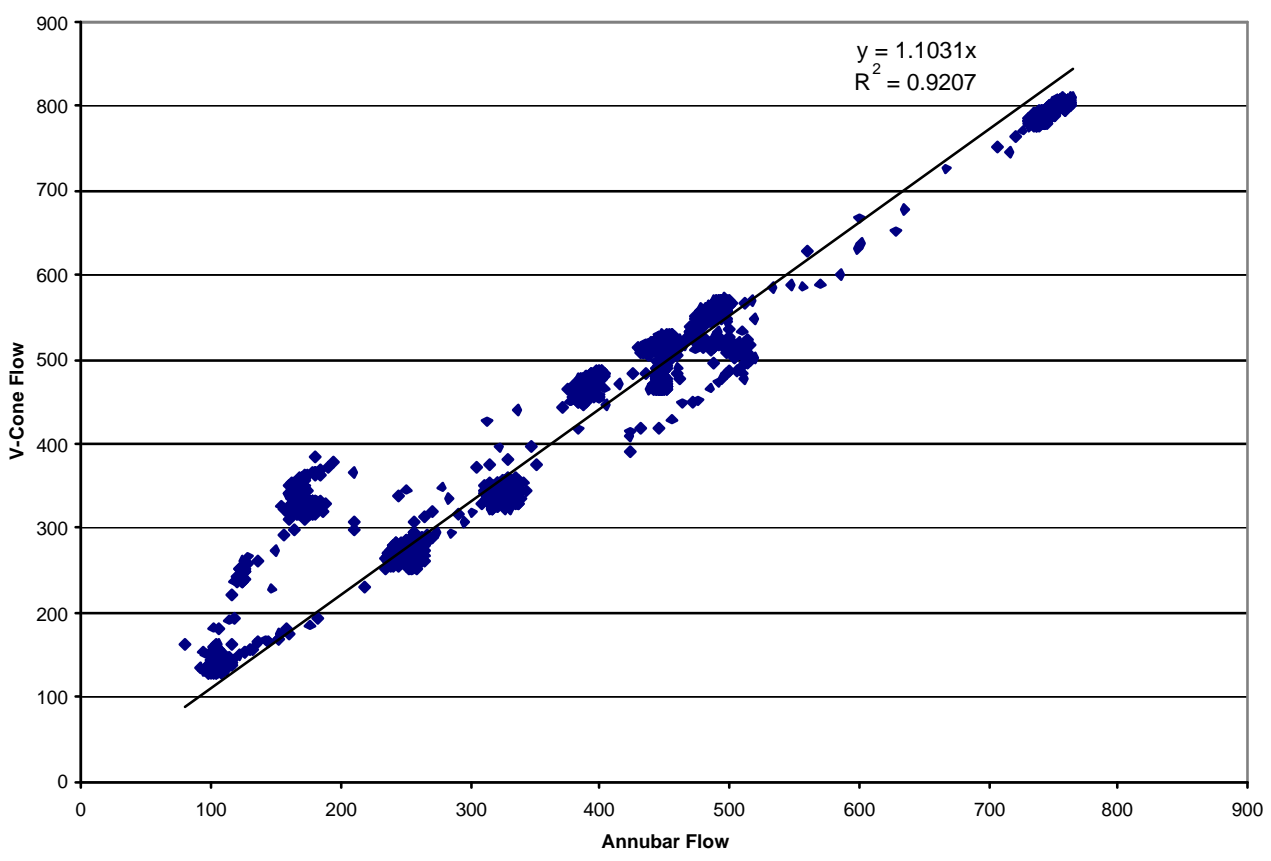

Figure 8.28 Flow rate regression analysis for the V-Cone and Annubar ${ }^{\circledR}$ for transient test VolvoSS2-02. 


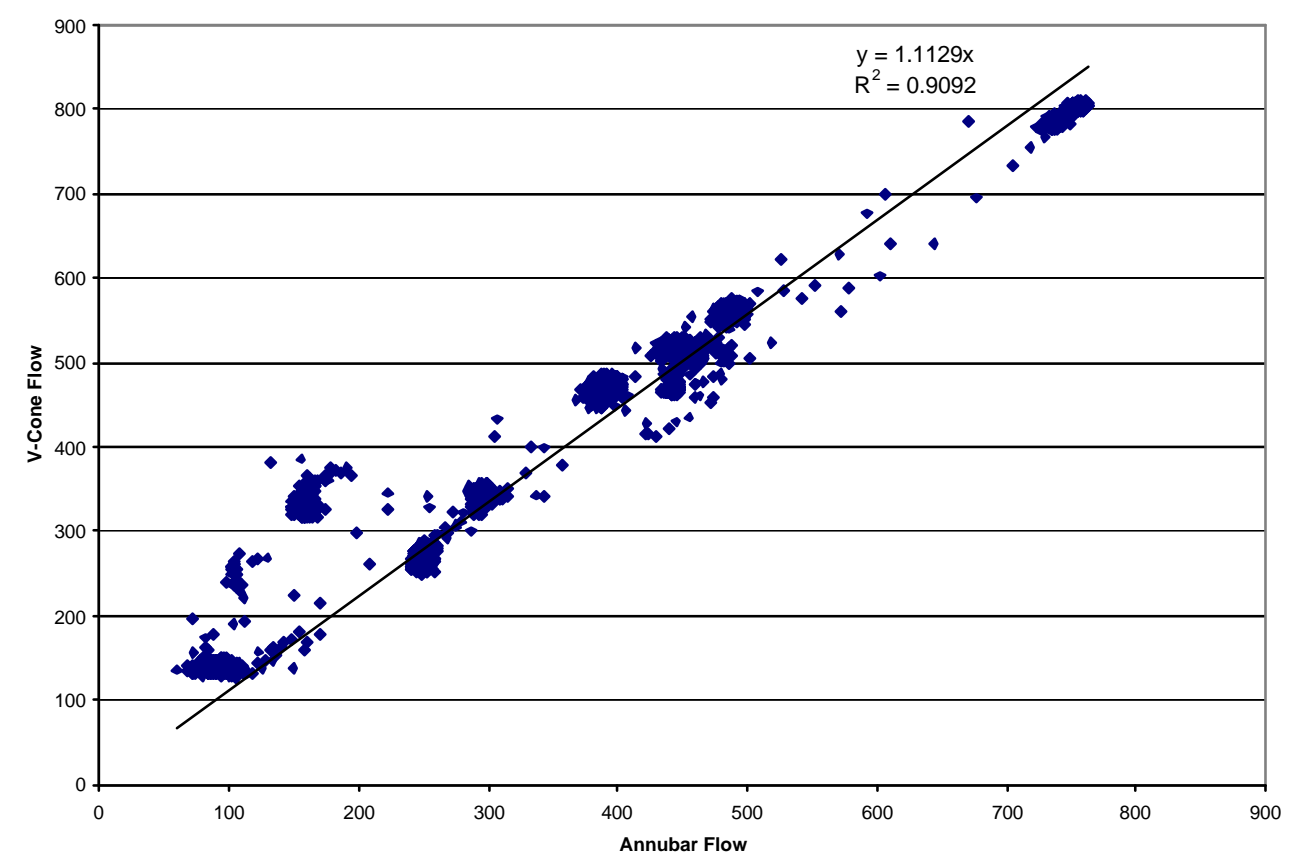

Figure 8.29 Flow rate regression analysis for the V-Cone and Annubar ${ }^{\circledR}$ for transient test VolvoSS2-03.

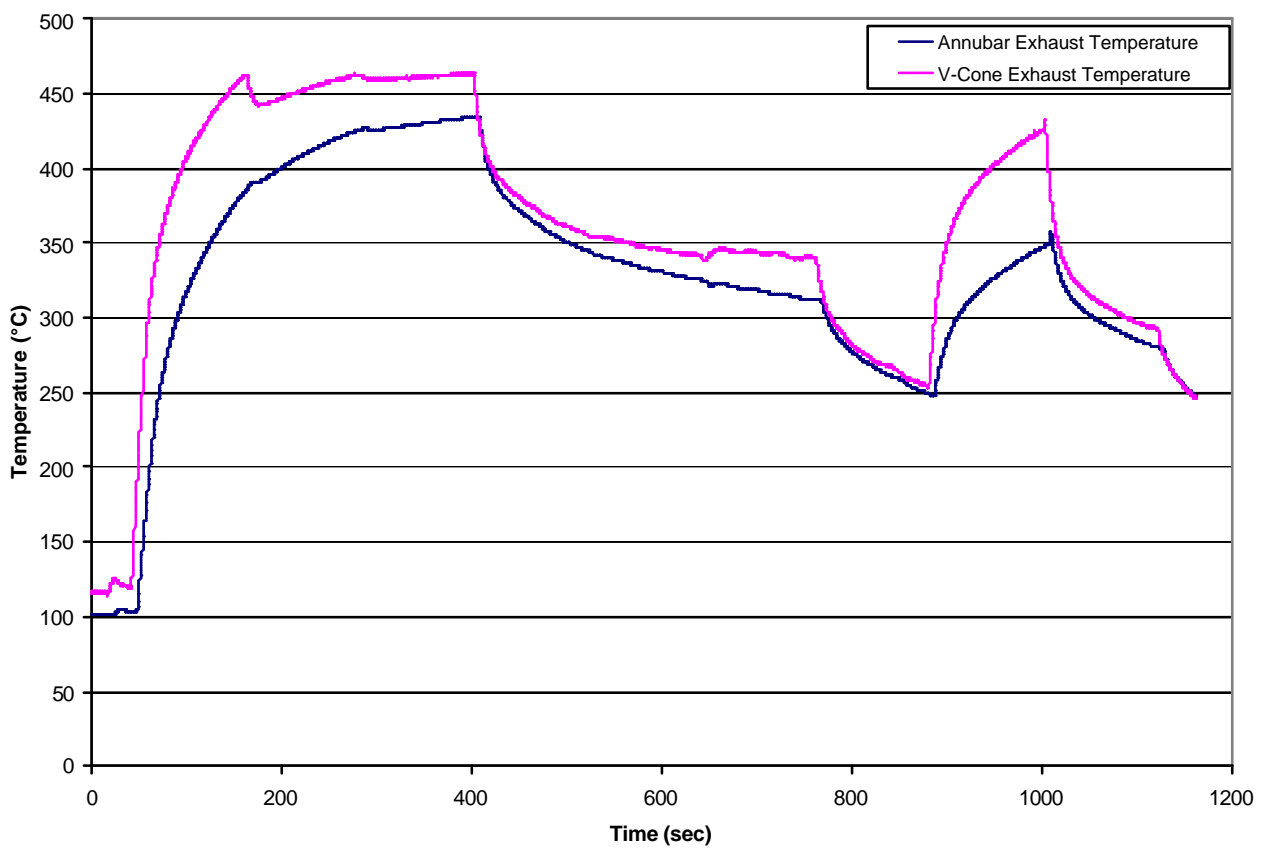

Figure 8.30 Exhaust temperature comparison of the V-Cone and Annubar ${ }^{\circledR}$. 


\subsection{Appendix C}

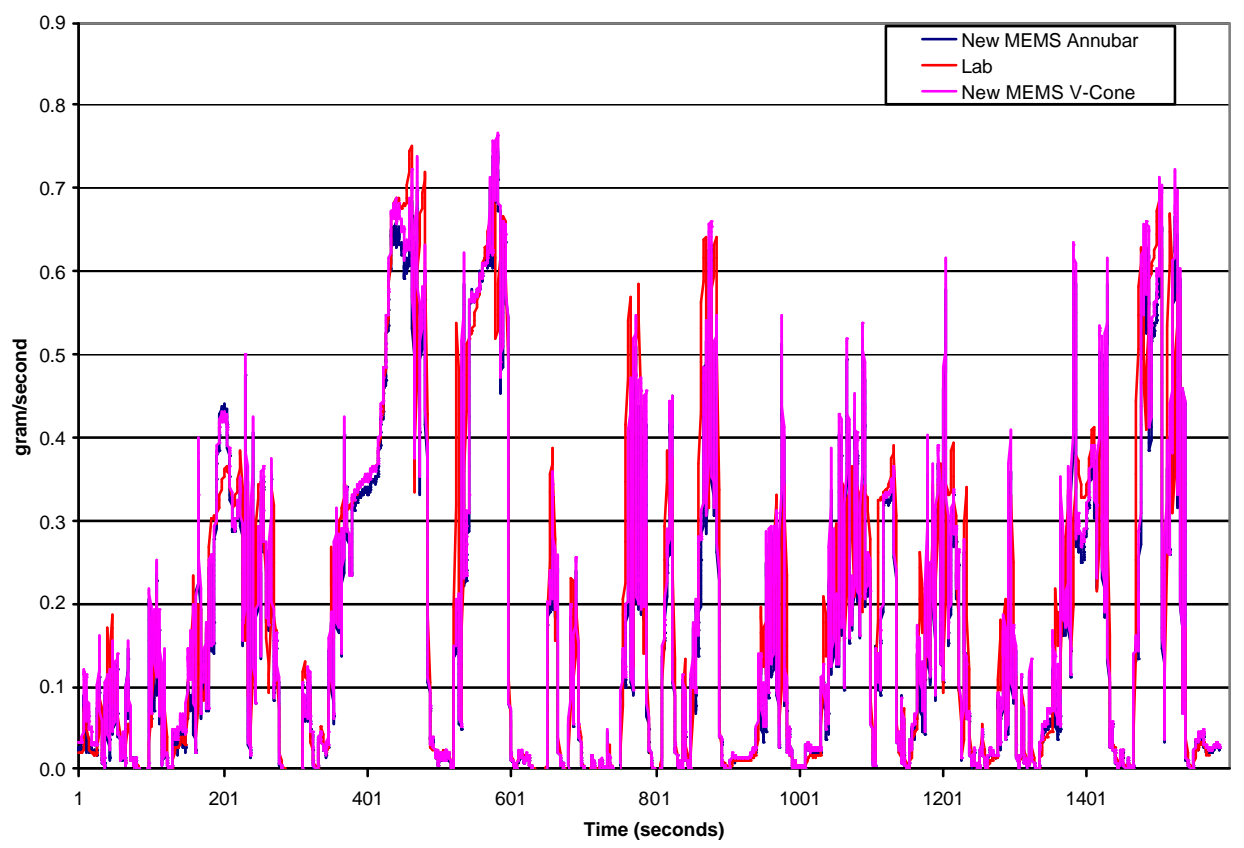

Figure 8.31 NOx mass emissions rates comparison between the V-Cone, Annubar ${ }^{\circledR}$, and Laboratory mass emissions rates, transient test VolvoPA1-01. 


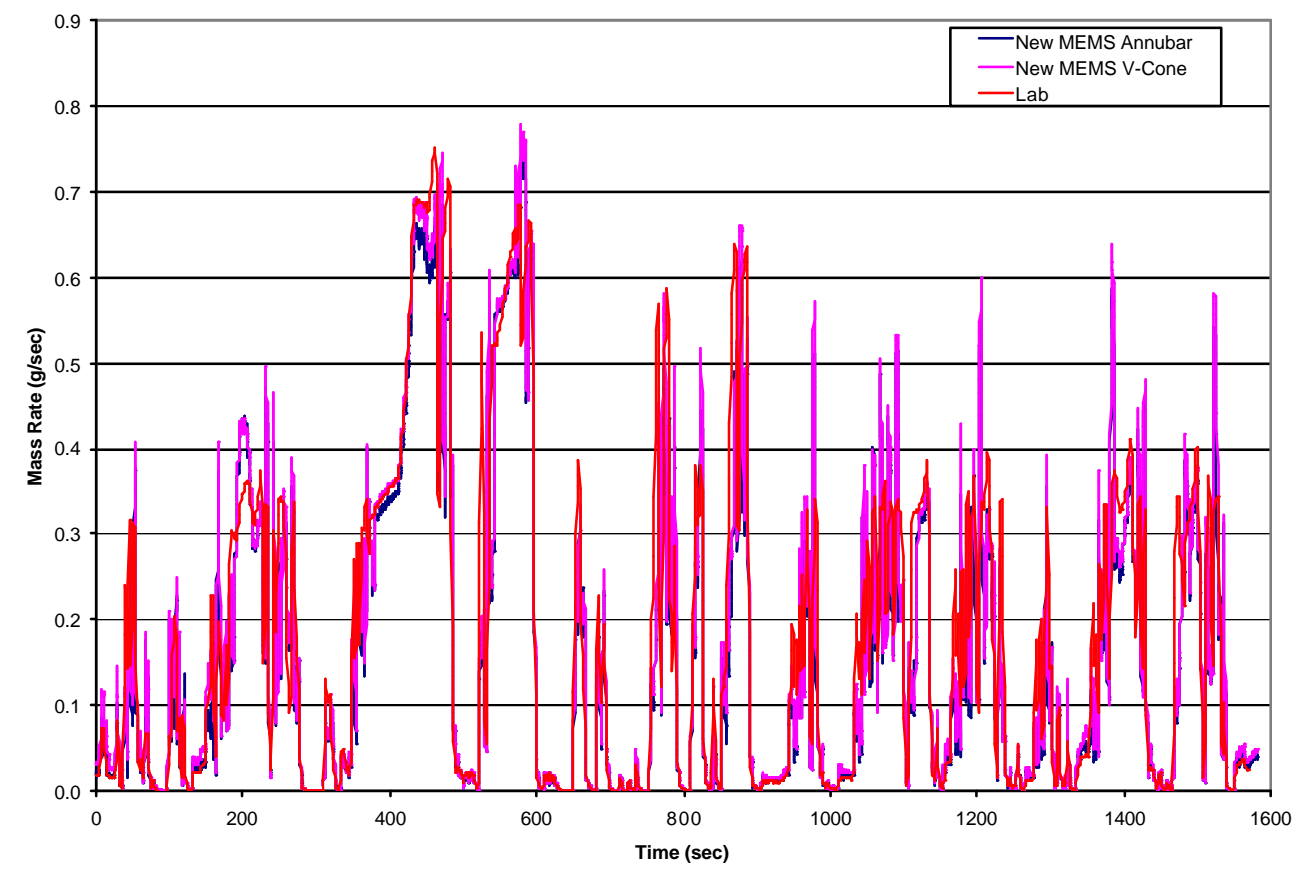

Figure 8.32 $\mathrm{NO}_{\mathrm{X}}$ mass emissions rates comparison between the V-Cone, Annubar ${ }^{\circledR}$, and Laboratory mass emissions rates, transient test VolvoPA1-02.

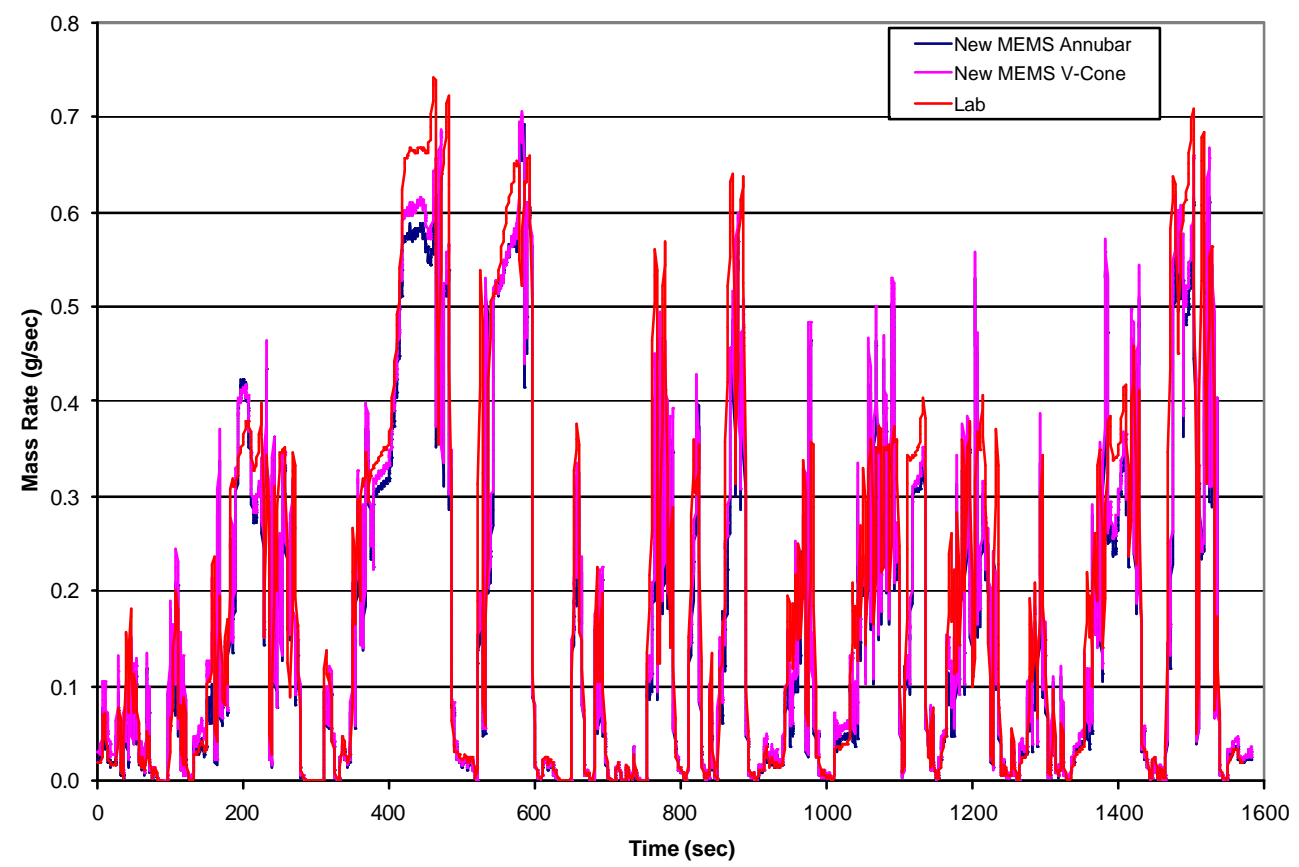

Figure 8.33 NO mass emissions rates comparison between the V-Cone, Annubar ${ }^{\circledR}$, and Laboratory mass emissions rates, transient test VolvoPA1-03. 


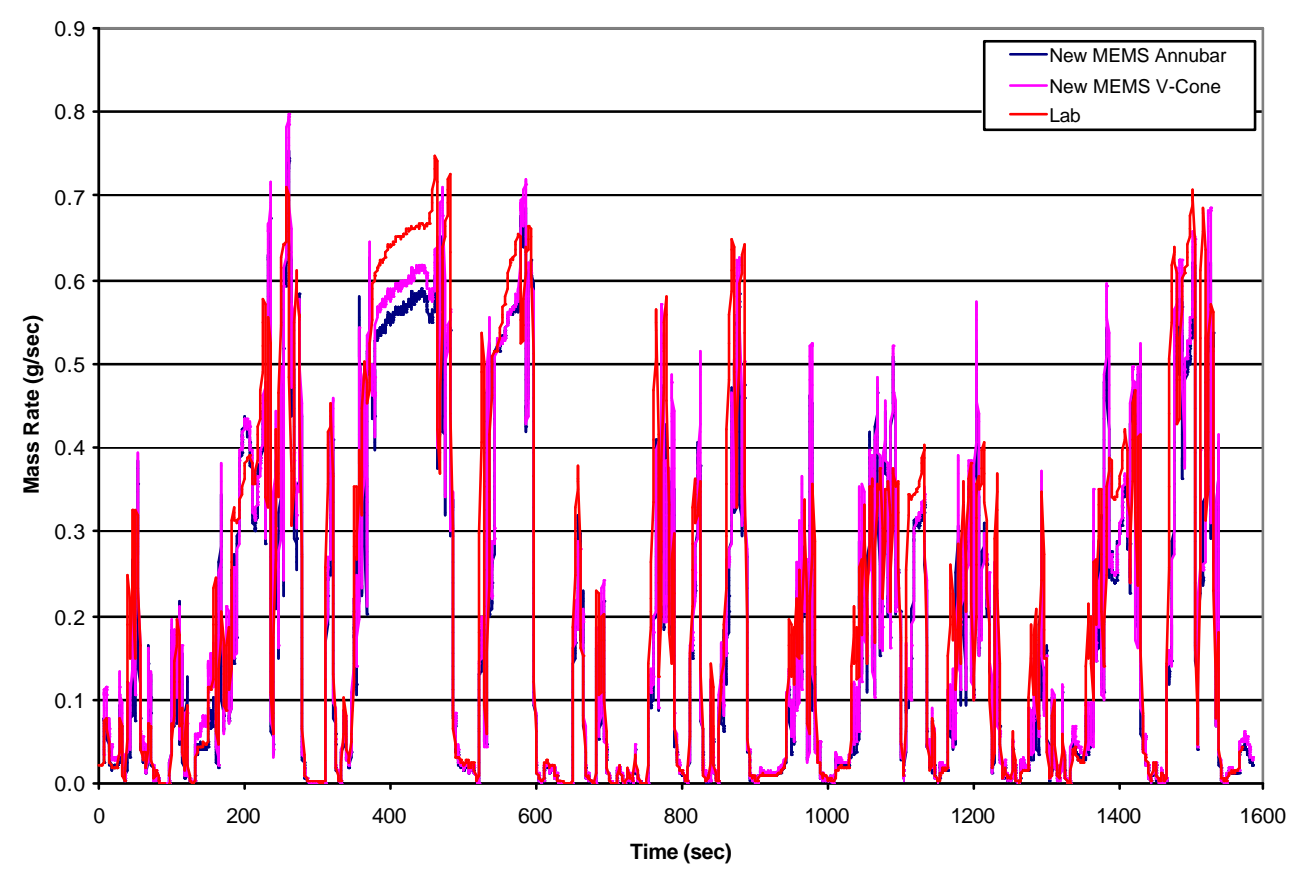

Figure 8.34 $\mathrm{NO}_{\mathrm{X}}$ mass emissions rates comparison between the V-Cone, Annubar ${ }^{\circledR}$, and Laboratory mass emissions rates, transient test VolvoPA1-04.

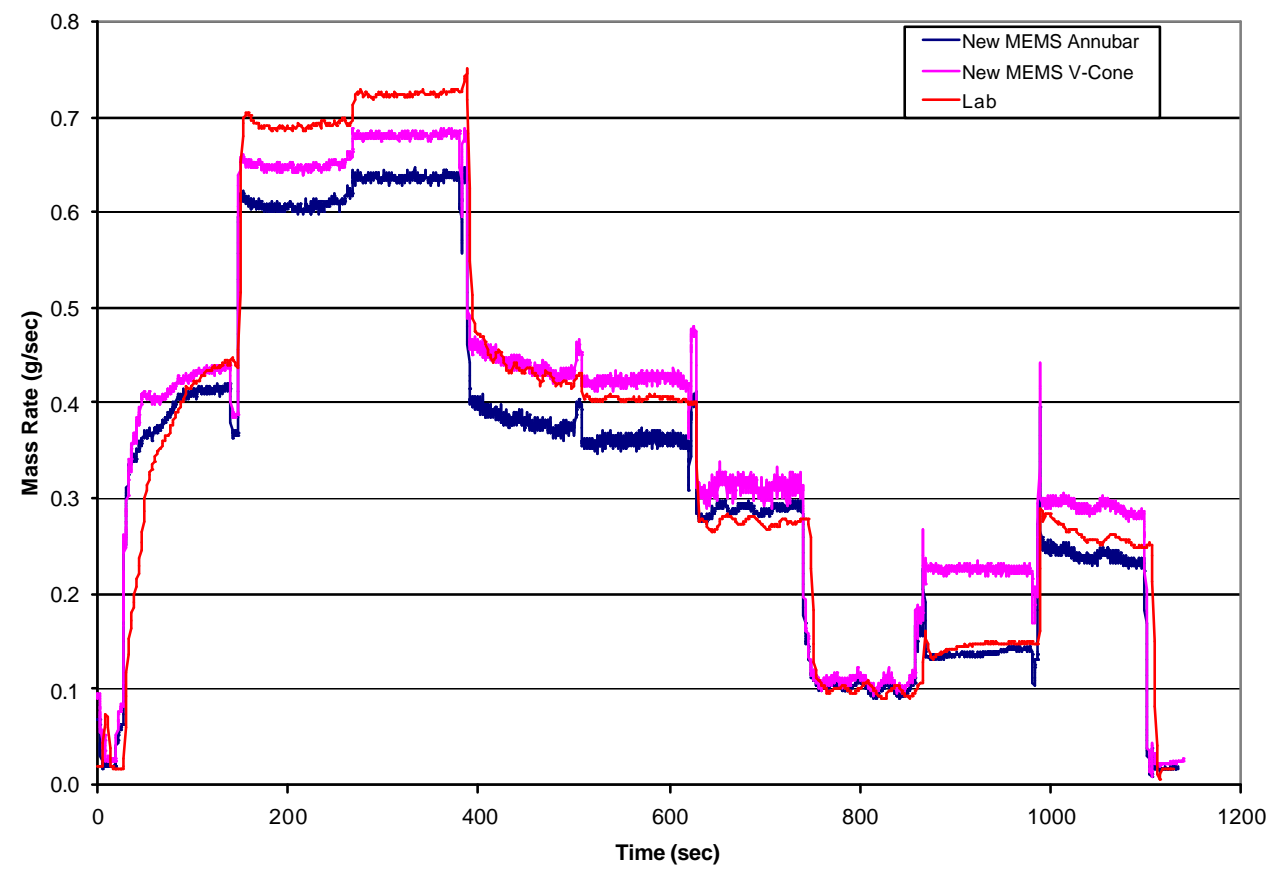

Figure 8.35 NO $\mathrm{N}_{\mathrm{X}}$ mass emissions rates comparison between the V-Cone, Annubar ${ }^{\circledR}$, and Laboratory mass emissions rates, transient test VolvoSS2-01. 


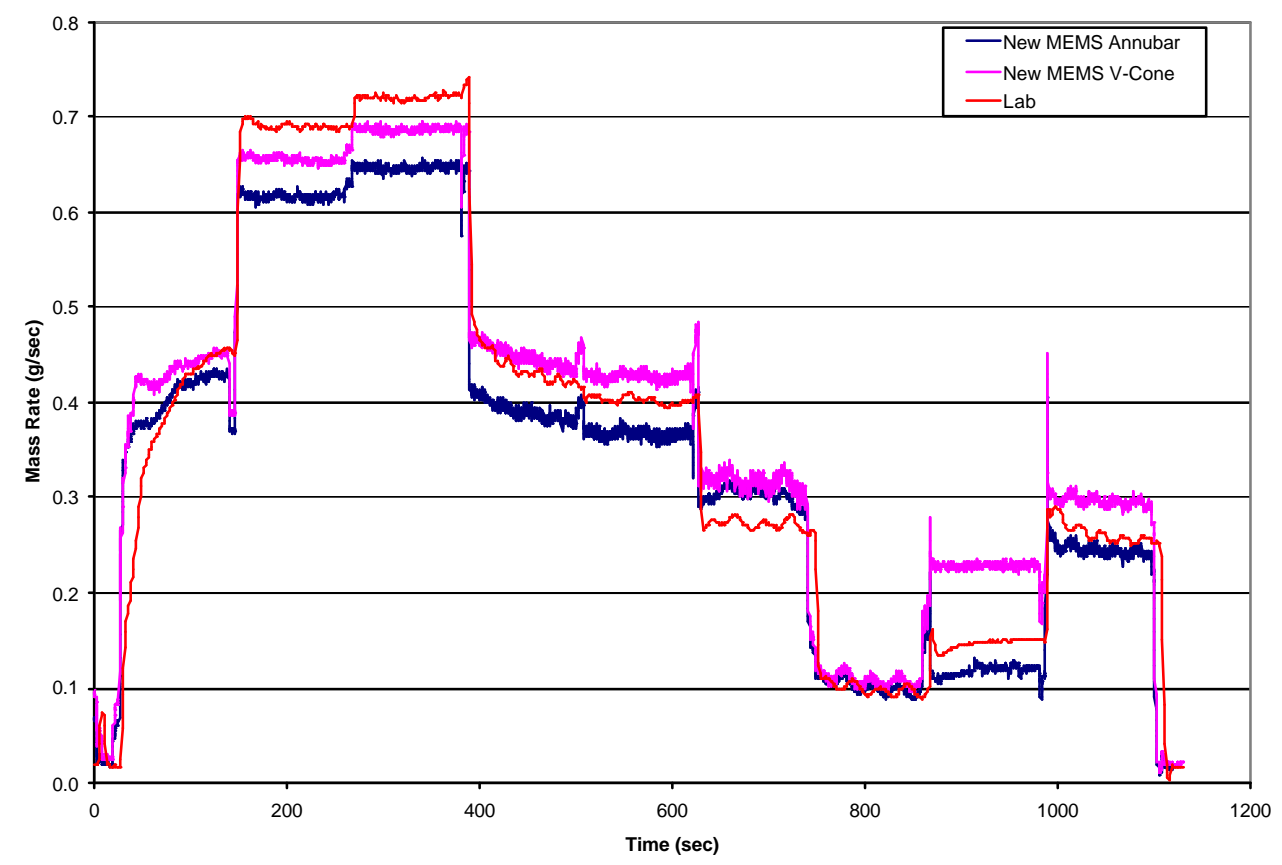

Figure 8.36 $\mathrm{NO}_{\mathrm{X}}$ mass emissions rates comparison between the V-Cone, Annubar ${ }^{\circledR}$, and Laboratory mass emissions rates, transient test VolvoSS2-02.

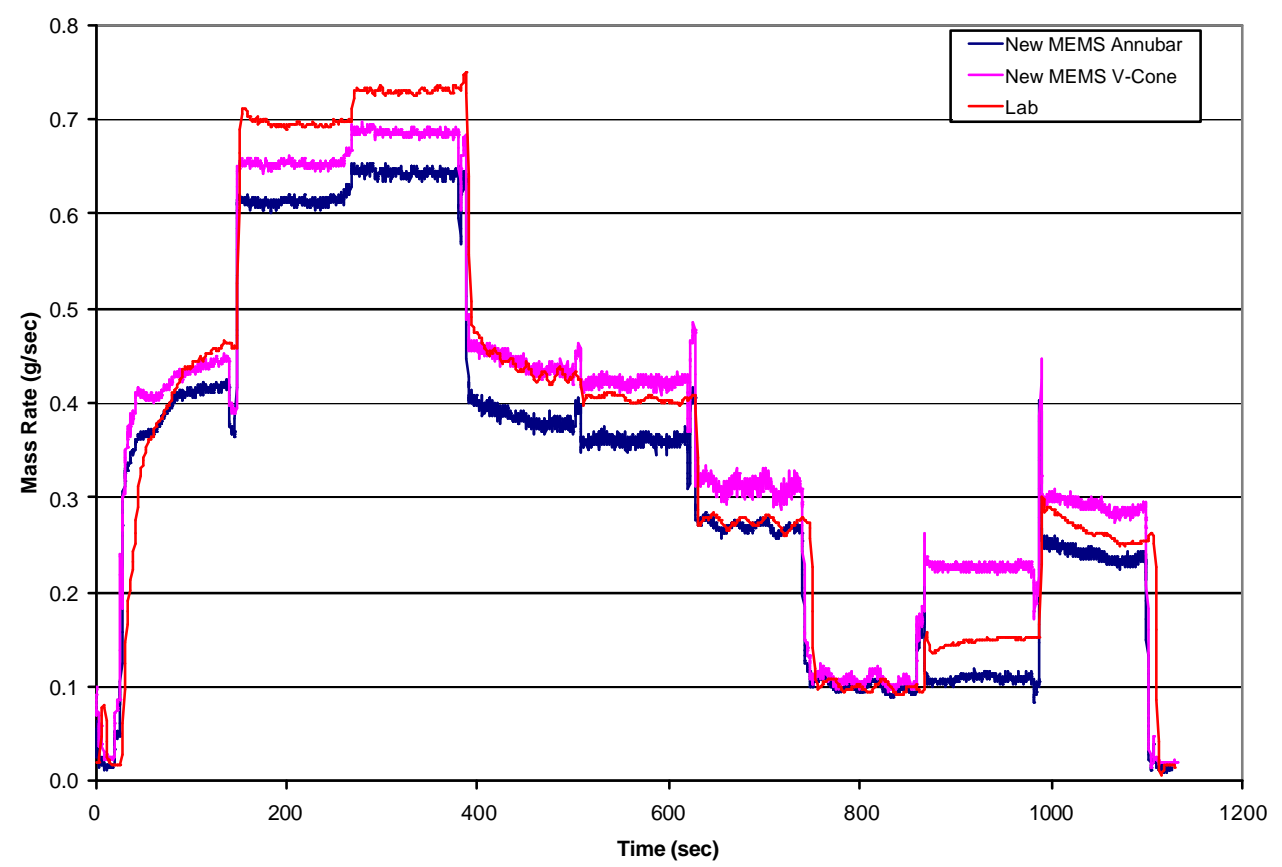

Figure 8.37 NO mass emissions rates comparison between the V-Cone, Annubar ${ }^{\circledR}$, and Laboratory mass emissions rates, transient test VolvoSS2-03. 


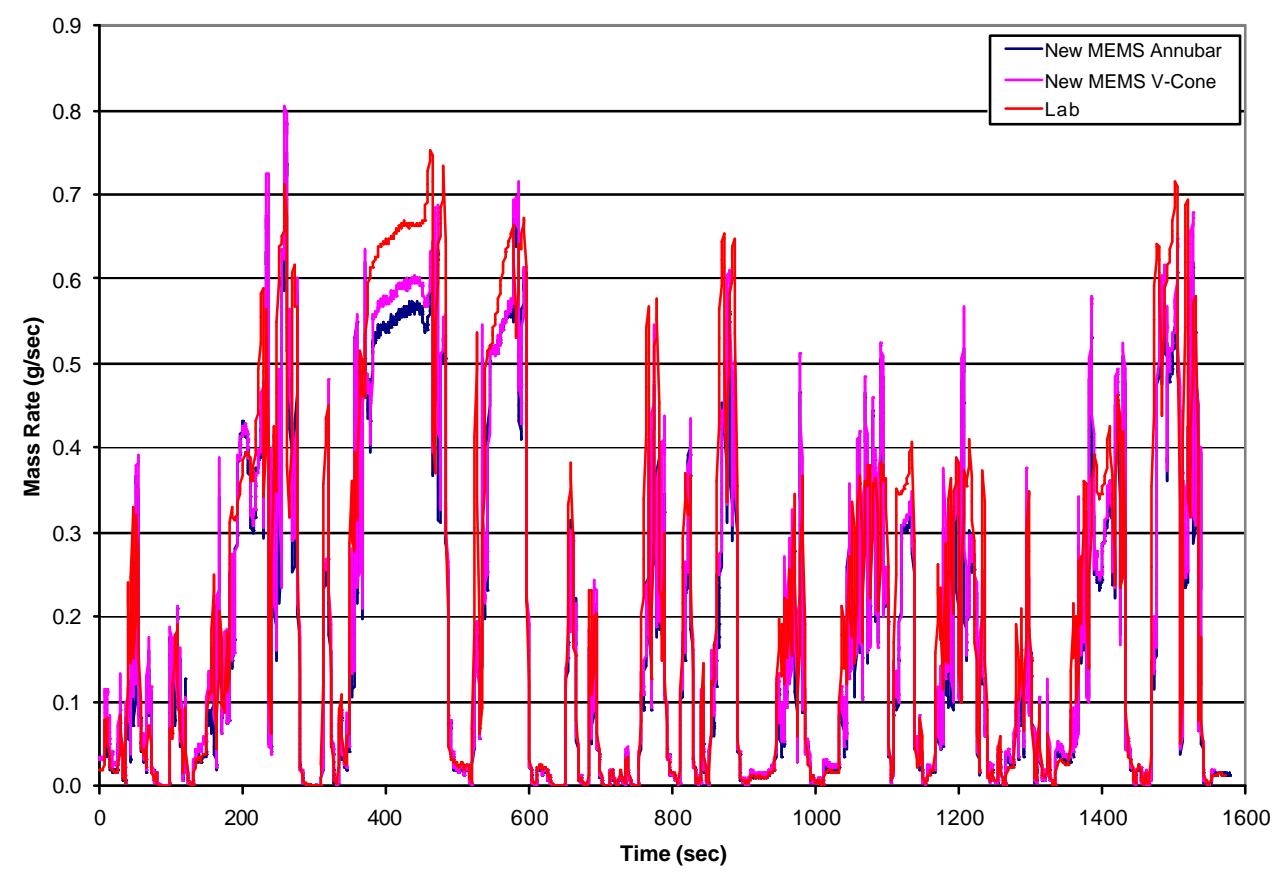

Figure 8.38 NO $\mathrm{N}_{\mathrm{X}}$ mass emissions rates comparison between the V-Cone, Annubar ${ }^{\circledR}$, and Laboratory mass emissions rates, transient test VolvoPA1 -05.

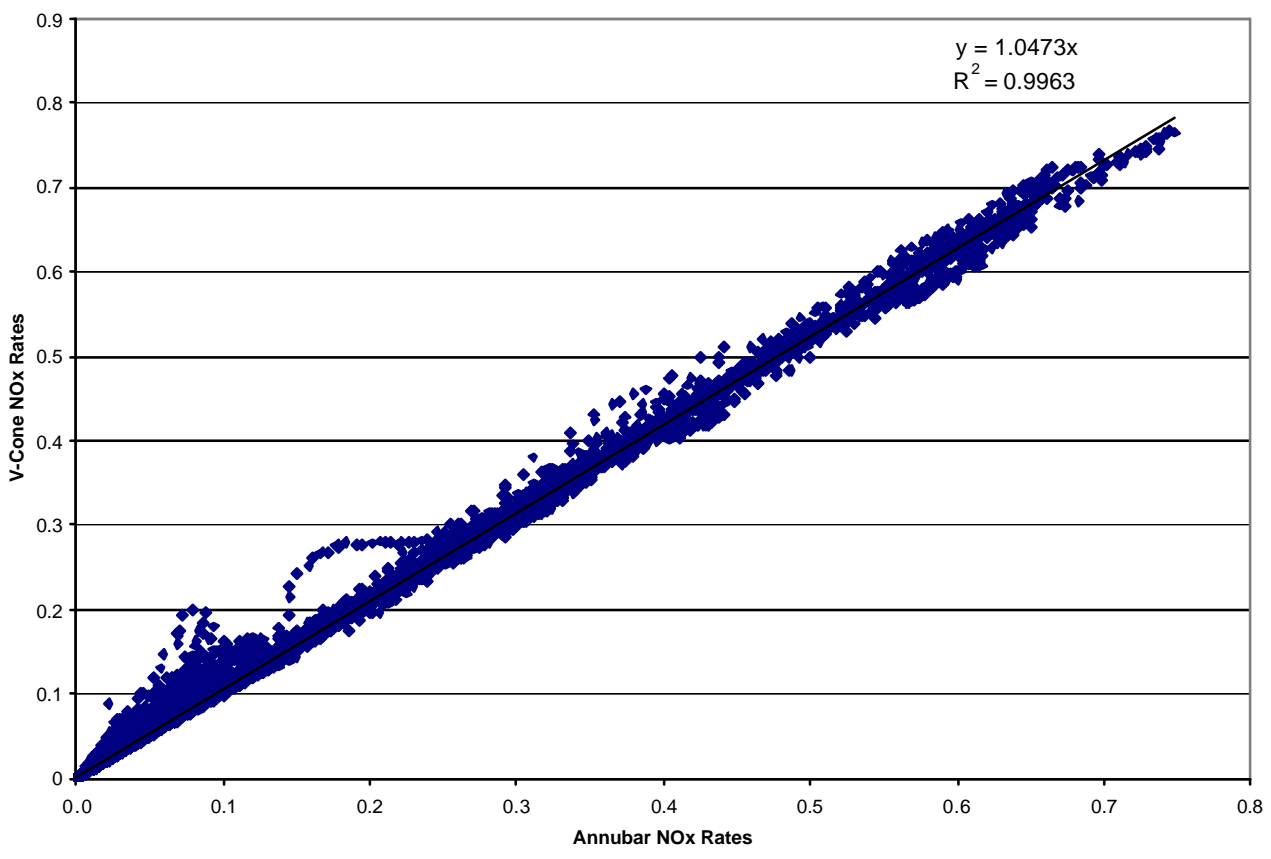

Figure 8.39 $\mathrm{NO}_{\mathrm{X}}$ regression analysis for test VolvoPA1 -01. 


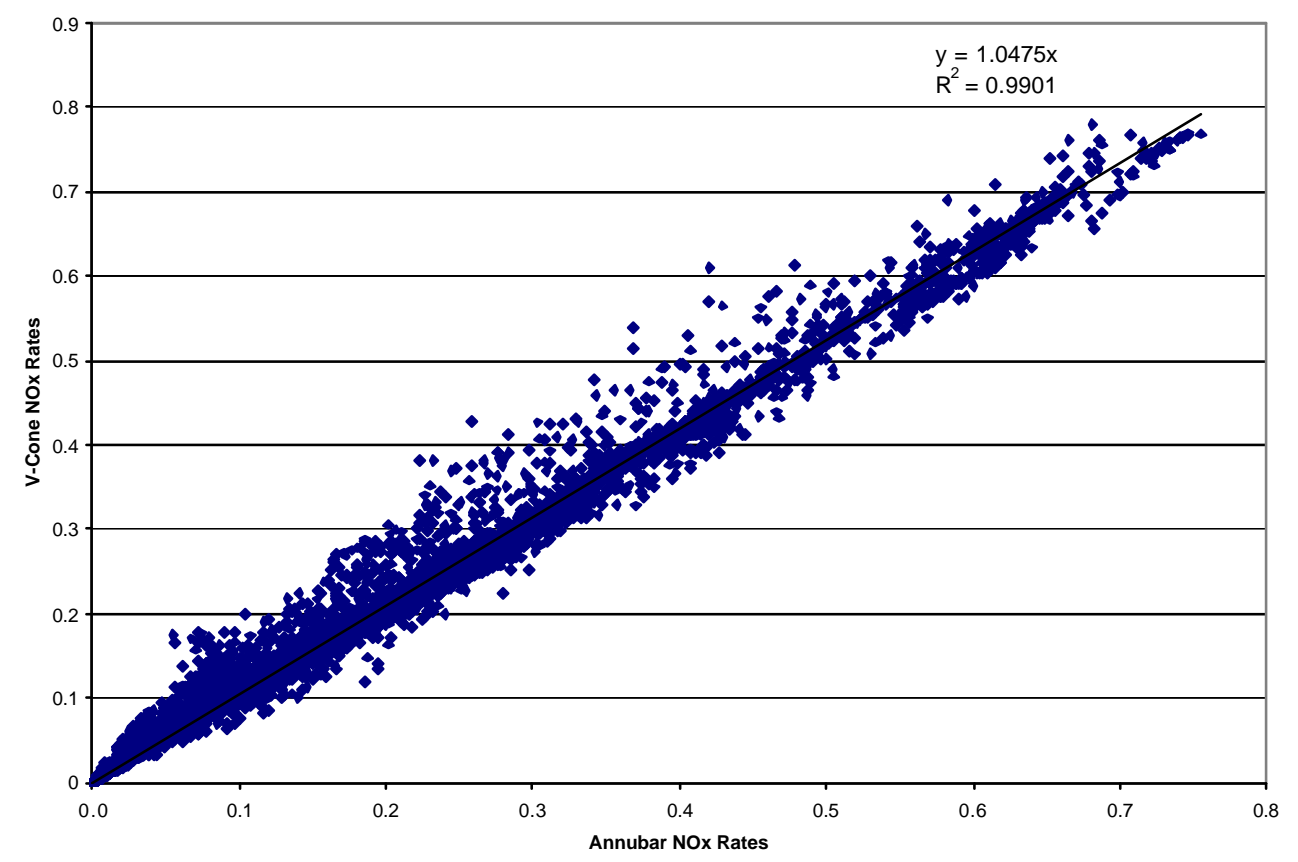

Figure 8.40 $\mathrm{NO}_{\mathrm{X}}$ regression analysis for test VolvoPA1 -02.

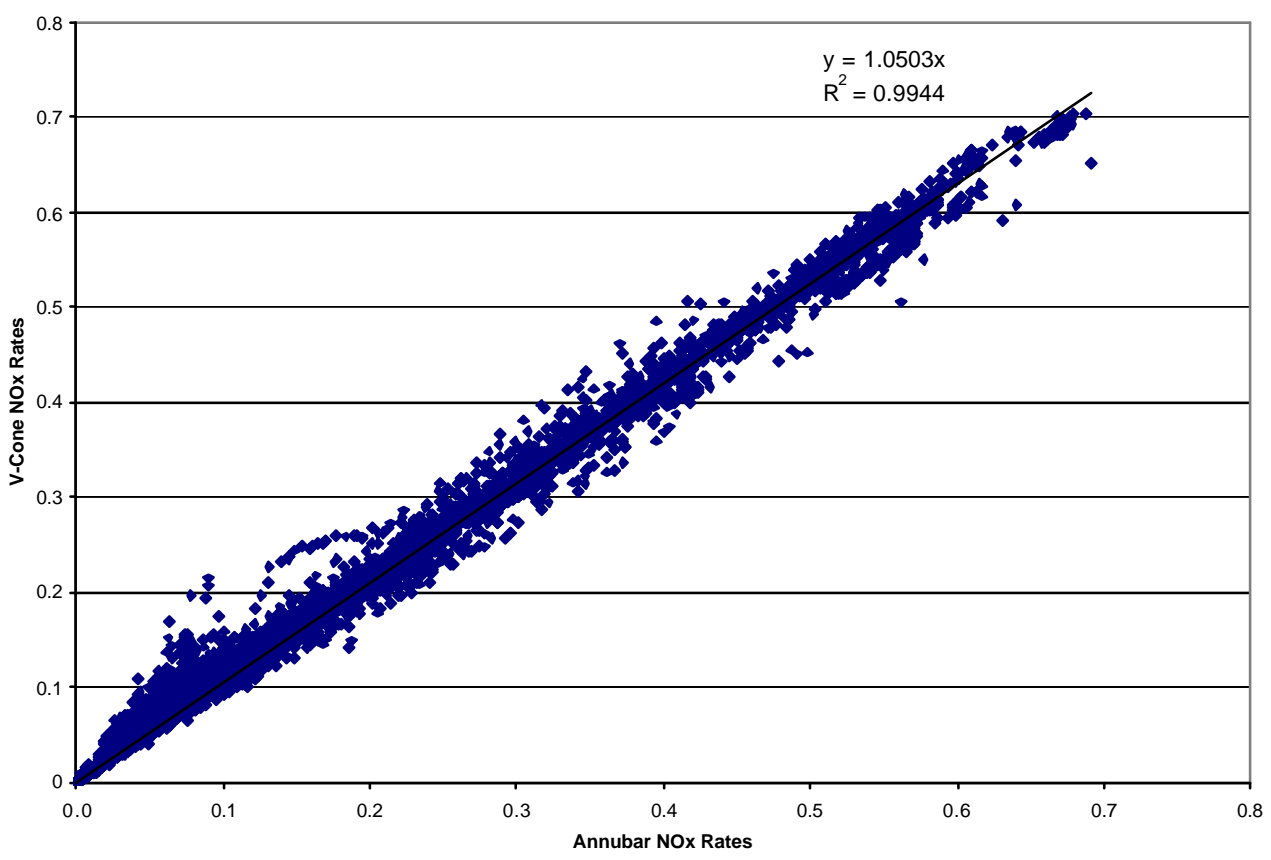

Figure 8.41 $\mathrm{NO}_{\mathrm{X}}$ regression analysis for test VolvoPA1 -03. 


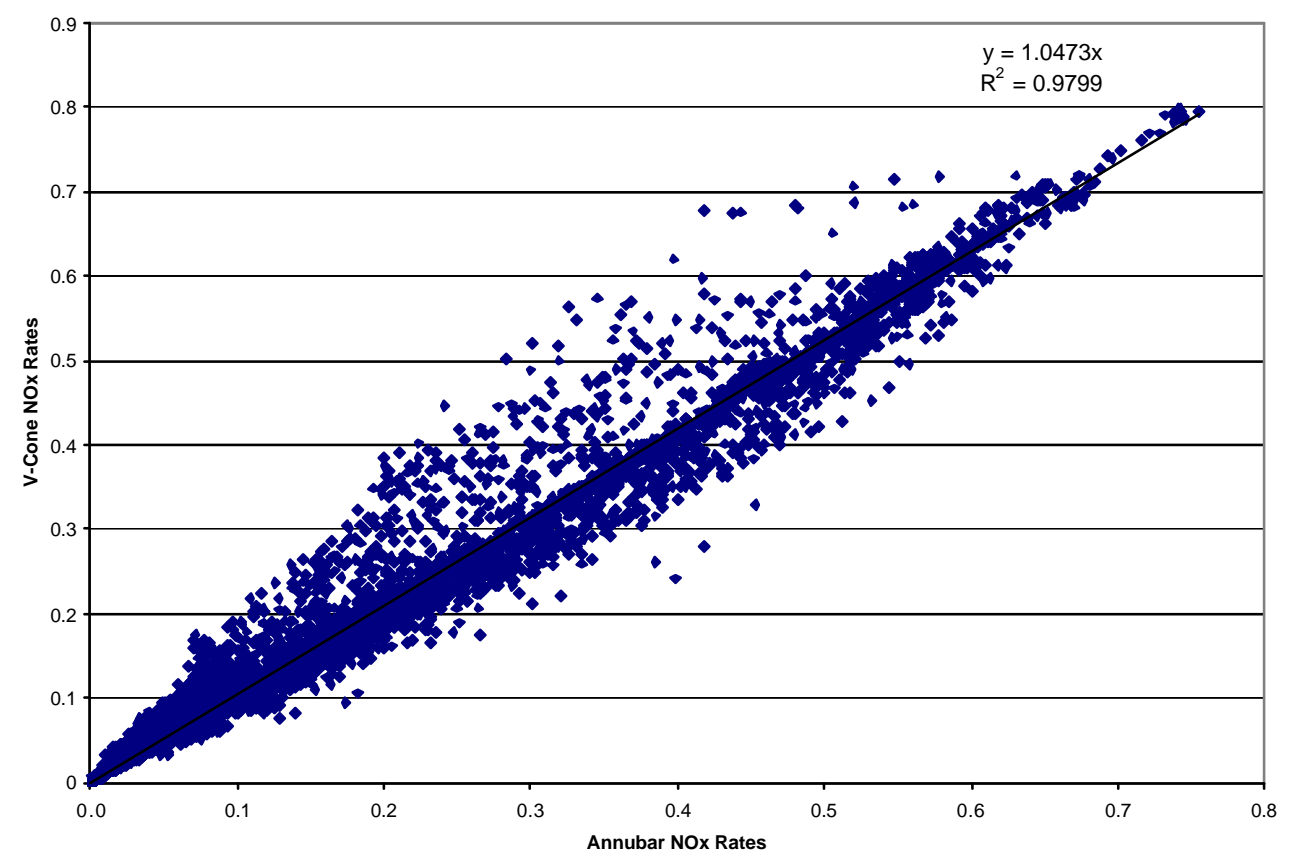

Figure 8.42 $\mathrm{NO}_{\mathrm{X}}$ regression analysis for test VolvoPA1-04.

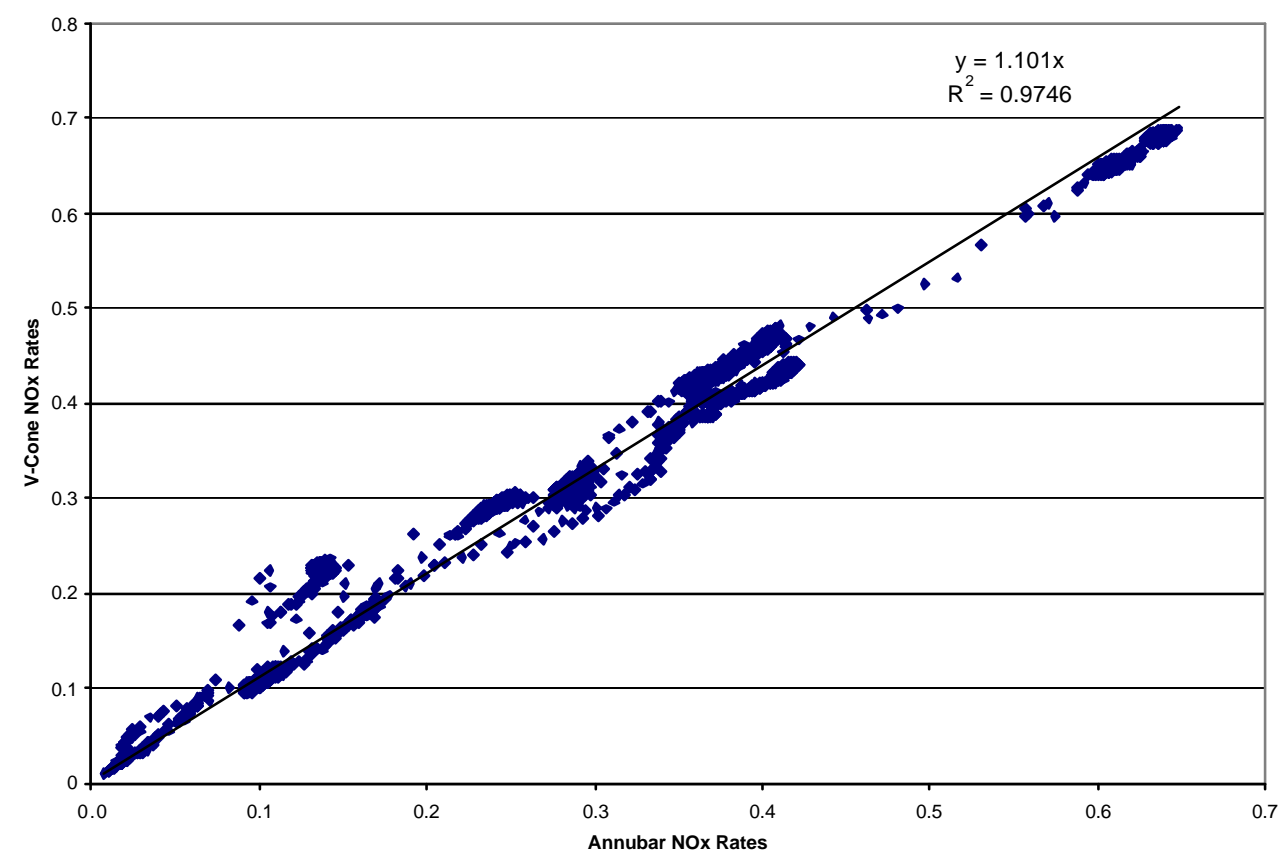

Figure 8.43 $\mathrm{NO}_{\mathrm{X}}$ regression analysis for test VolvoSS2-01. 


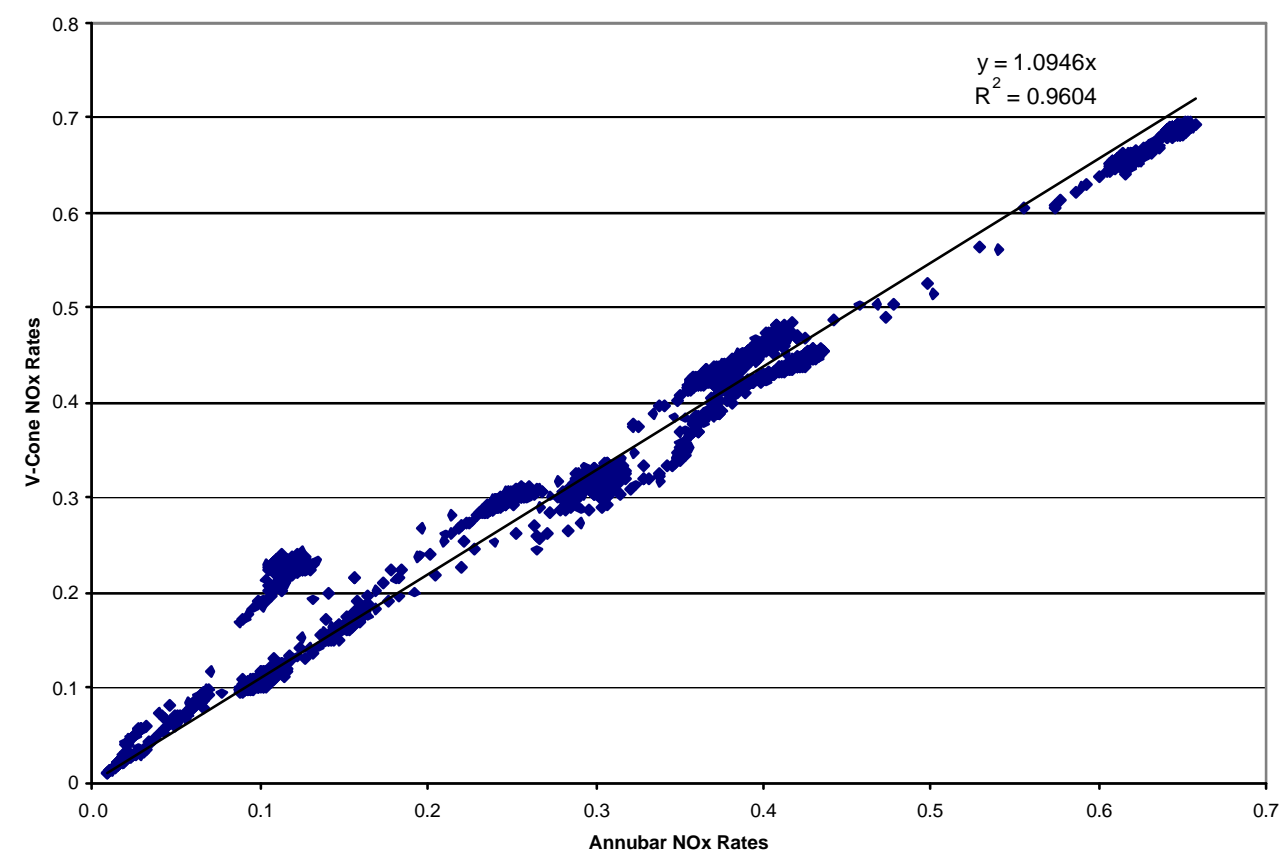

Figure 8.44 NO $\mathrm{N}_{\mathrm{X}}$ regression analysis for test VolvoSS2-02.

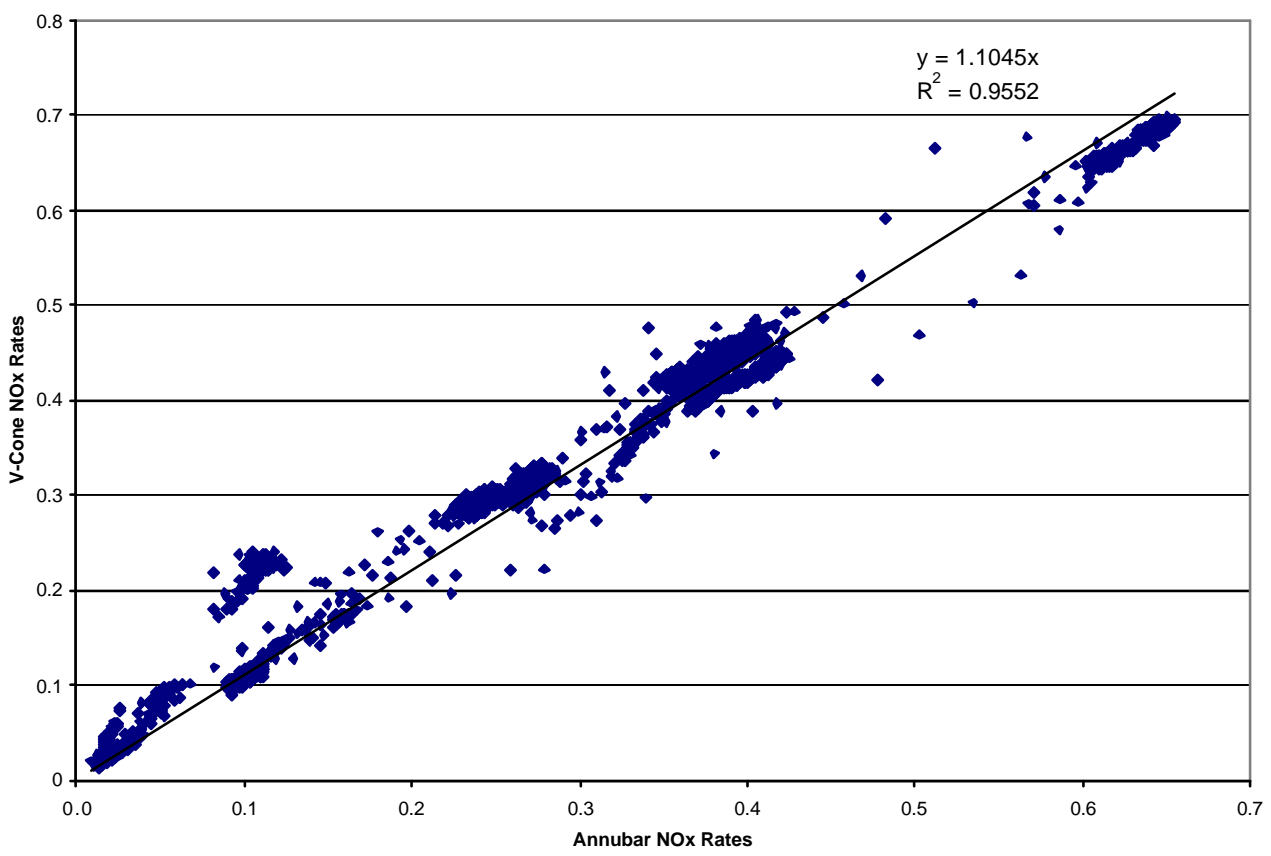

Figure 8.45 $\mathrm{NO}_{\mathrm{X}}$ regression analysis for test VolvoSS2-03. 


\subsection{Appendix D}

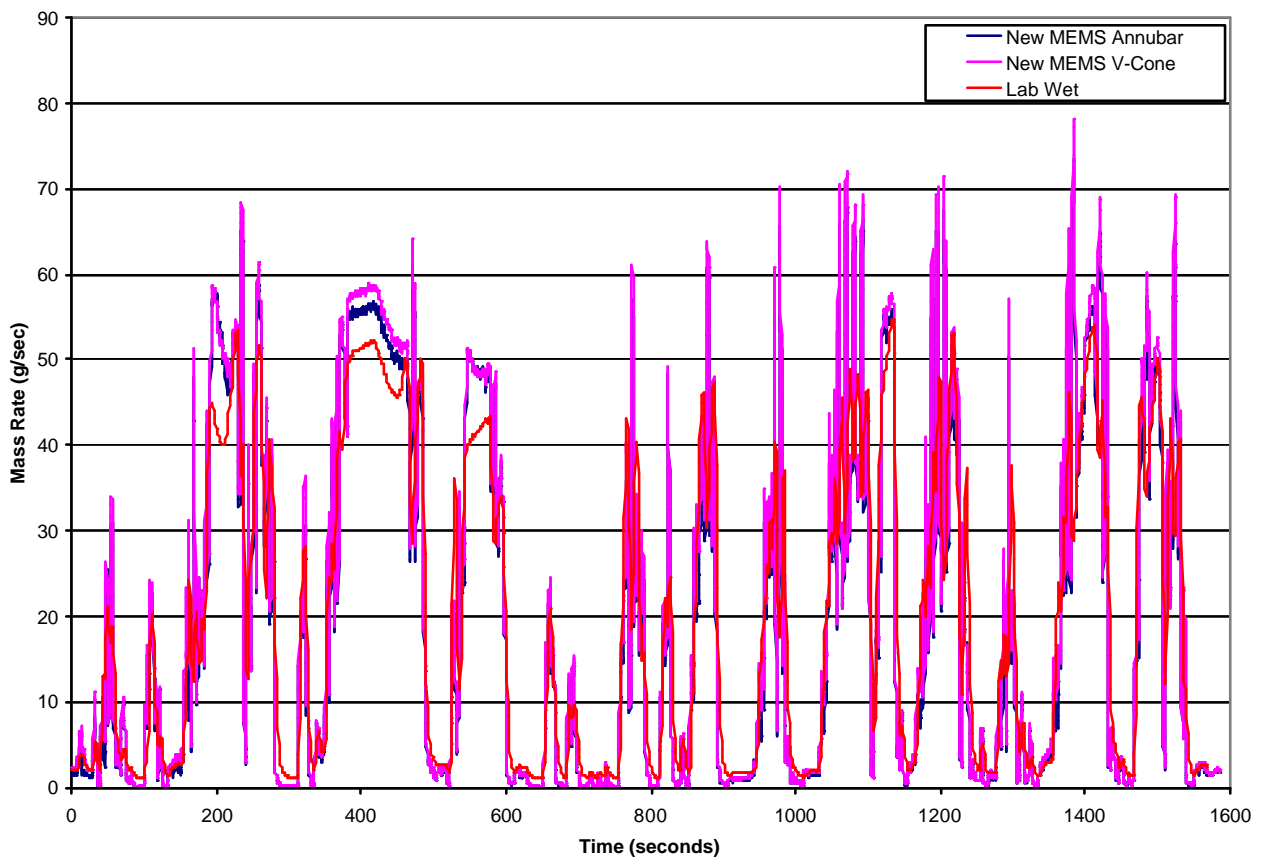

Figure 8.46 $\mathrm{CO}_{2}$ mass emissions rates comparison between the V-Cone, Annubar ${ }^{\circledR}$, and Laboratory mass emissions rates, transient test VolvoPA1-01. 


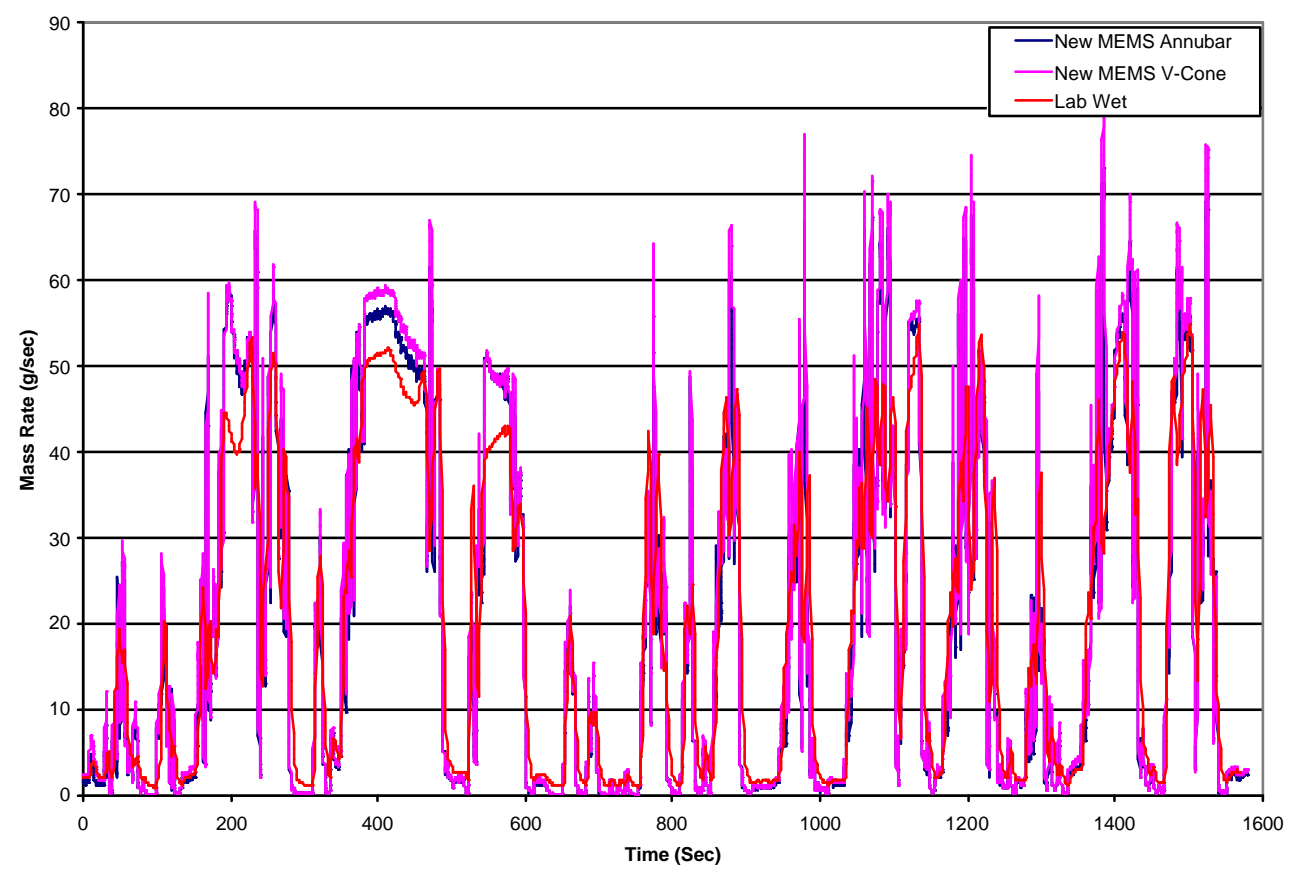

Figure 8.47 $\mathrm{CO}_{2}$ mass emissions rates comparison between the V-Cone, Annubar ${ }^{\circledR}$, and Laboratory mass emissions rates, transient test VolvoPA1-02.

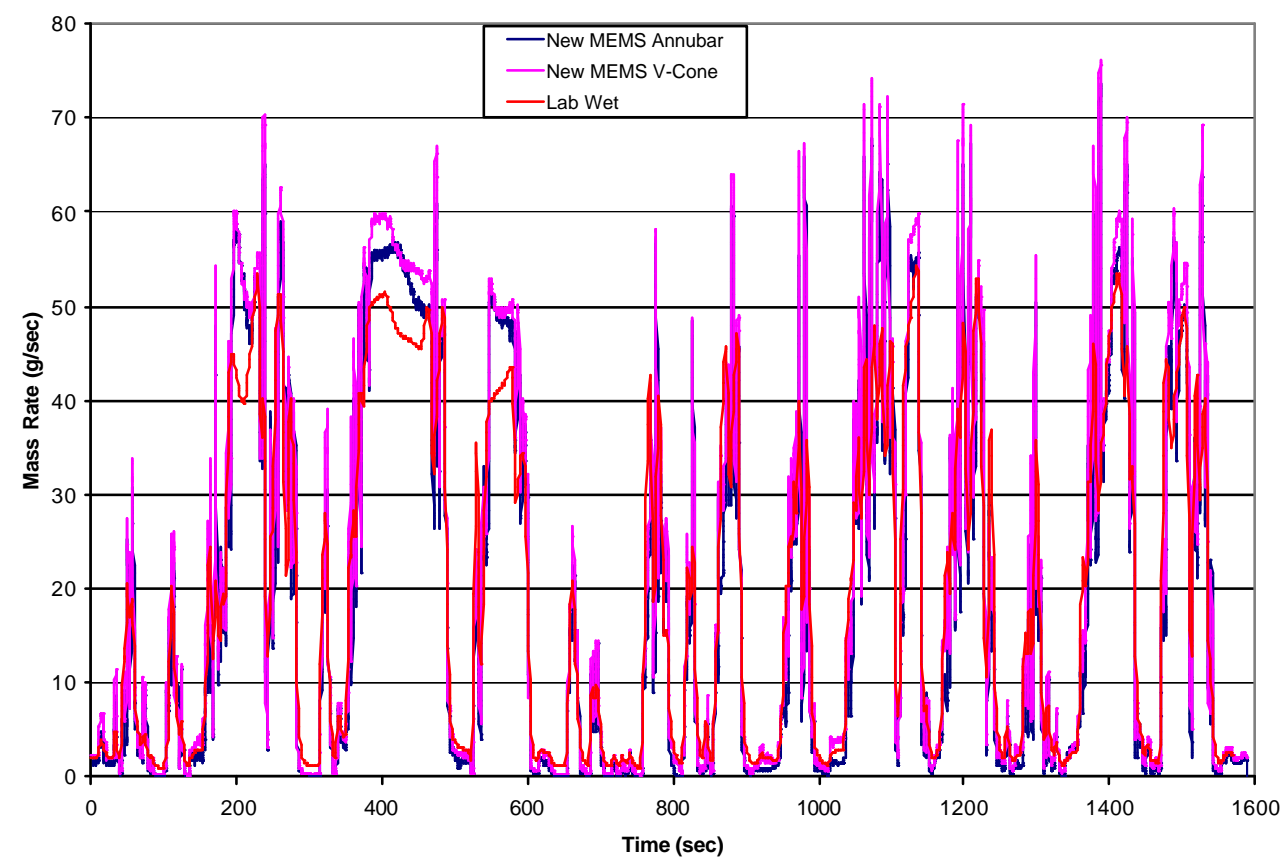

Figure 8.48 $\mathrm{CO}_{2}$ mass emissions rates comparison between the V-Cone, Annubar ${ }^{\circledR}$, and Laboratory mass emissions rates, transient test VolvoPA1-03. 


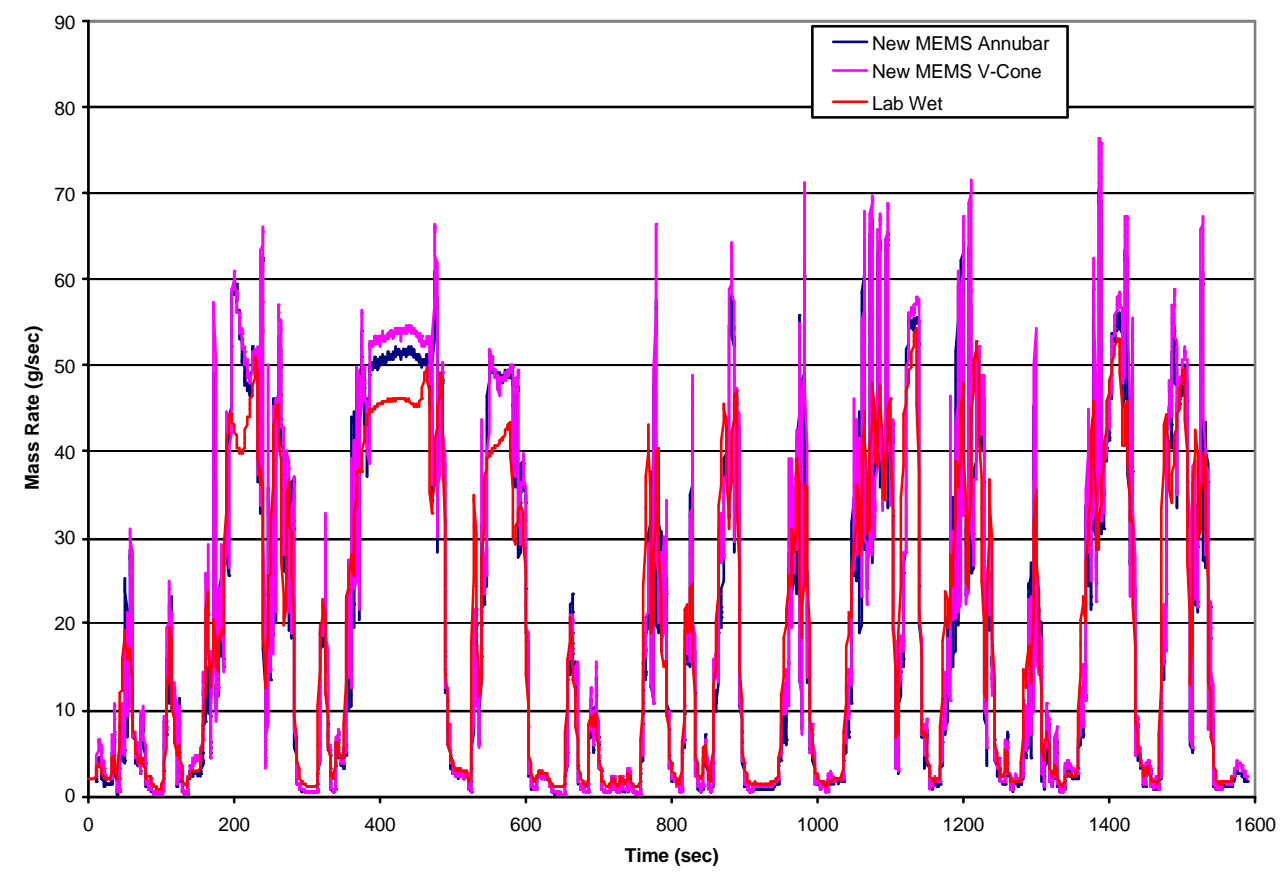

Figure 8.49 $\mathrm{CO}_{2}$ mass emissions rates comparison between the V-Cone, Annubar ${ }^{\circledR}$, and Laboratory mass emissions rates, transient test VolvoPA1-04.

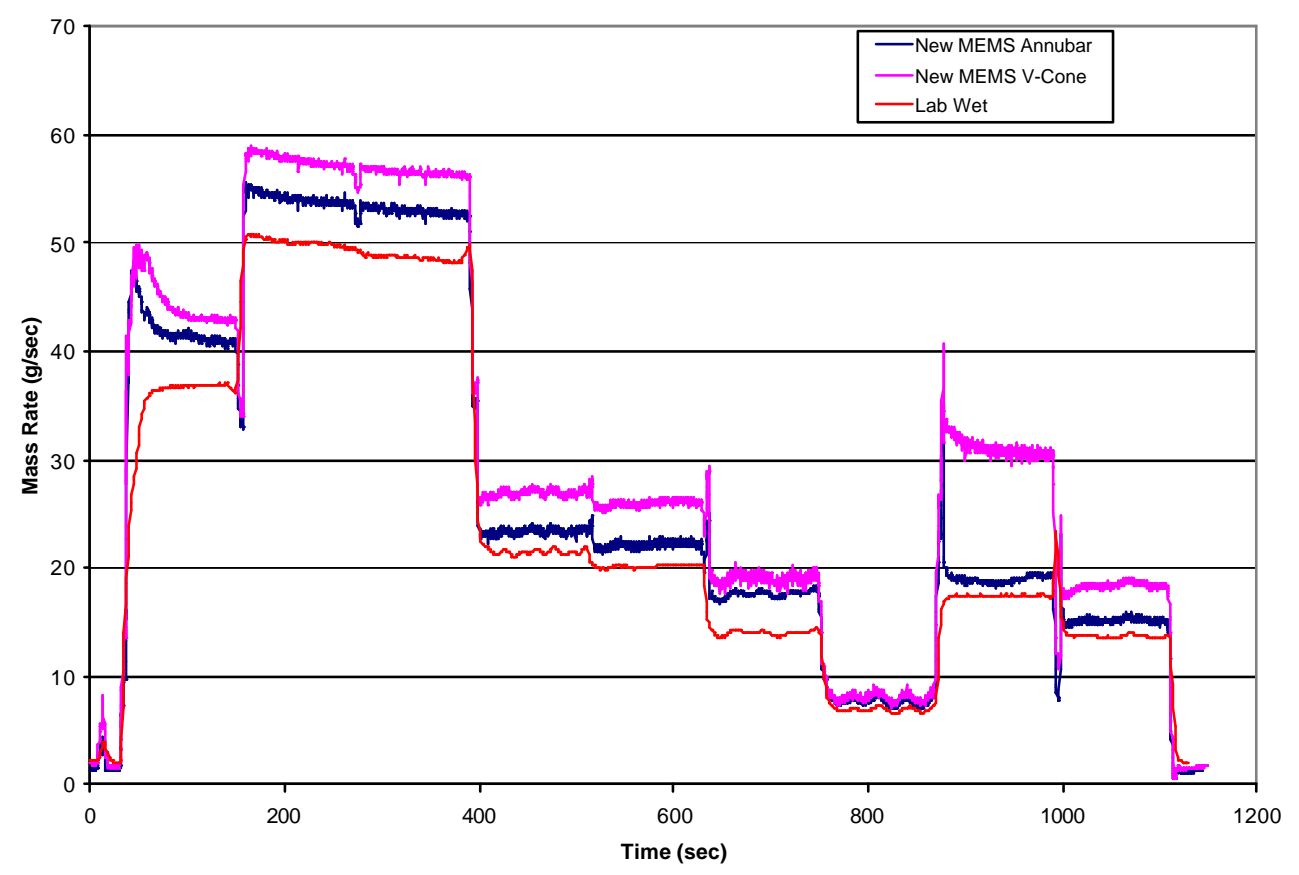

Figure 8.50 $\mathrm{CO}_{2}$ mass emissions rates comparison between the V-Cone, Annubar ${ }^{\circledR}$, and Laboratory mass emissions rates, transient test VolvoSS2-01. 


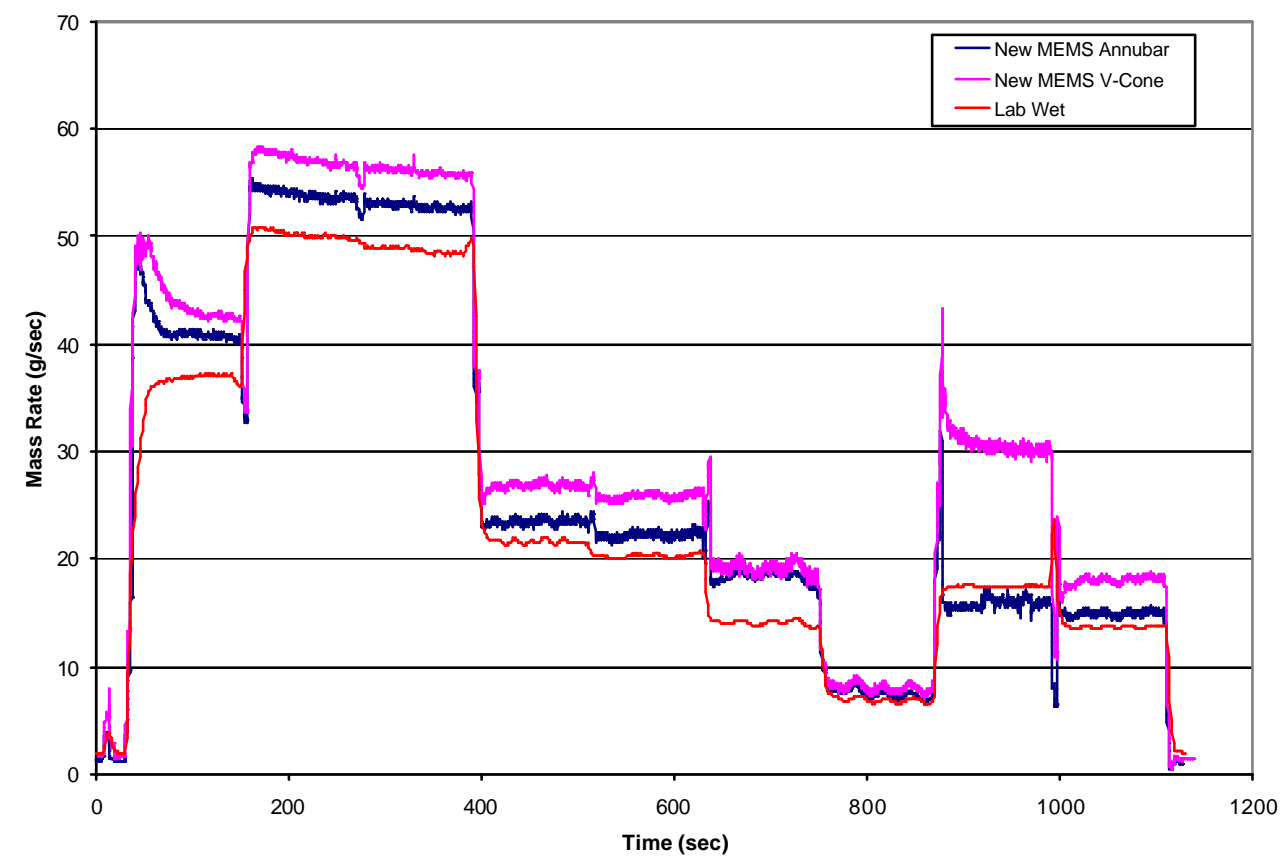

Figure 8.51 $\mathrm{CO}_{2}$ mass emissions rates comparison between the V-Cone, Annubar ${ }^{\circledR}$, and Laboratory mass emissions rates, transient test VolvoSS2-02.

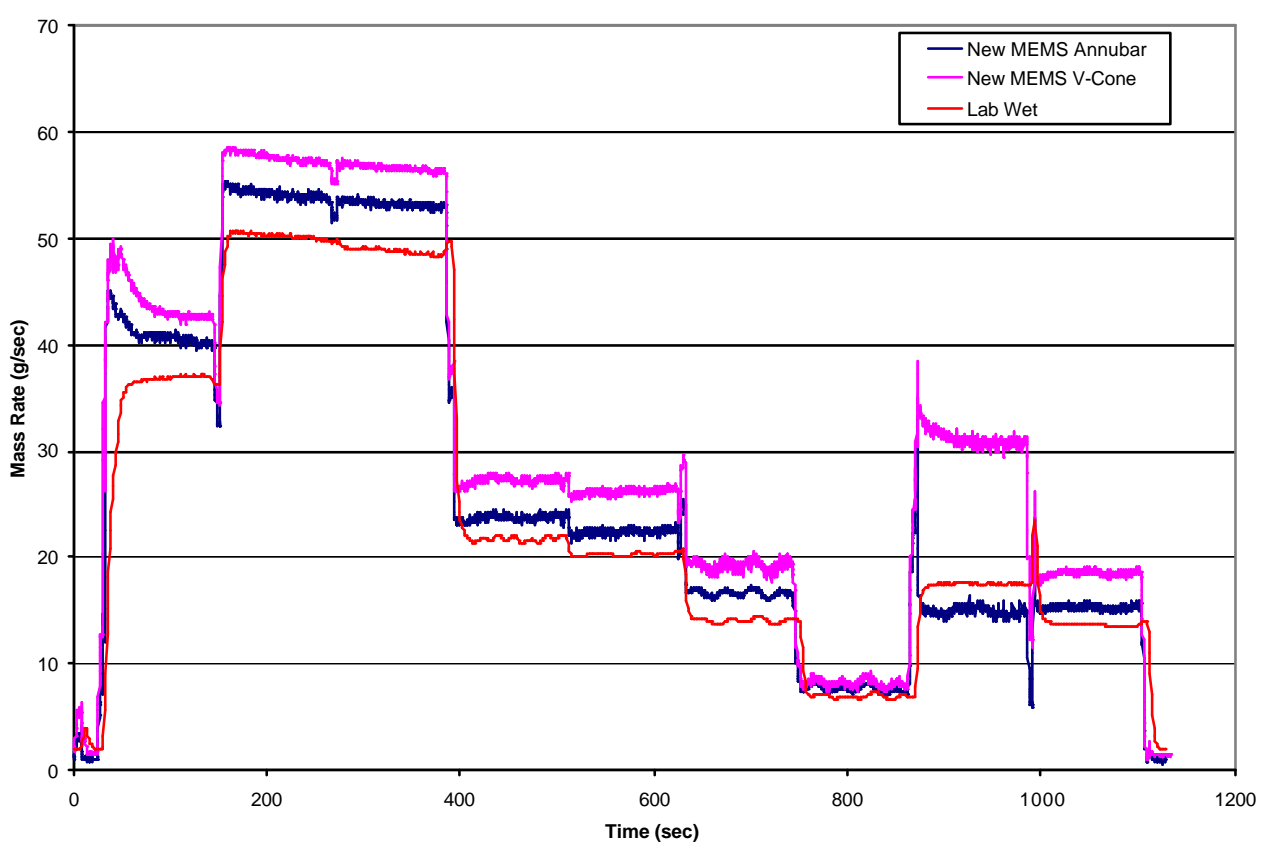

Figure 8.52 $\mathrm{CO}_{2}$ mass emissions rates comparison between the V-Cone, Annubar ${ }^{\circledR}$, and Laboratory mass emissions rates, transient test VolvoSS2-03. 


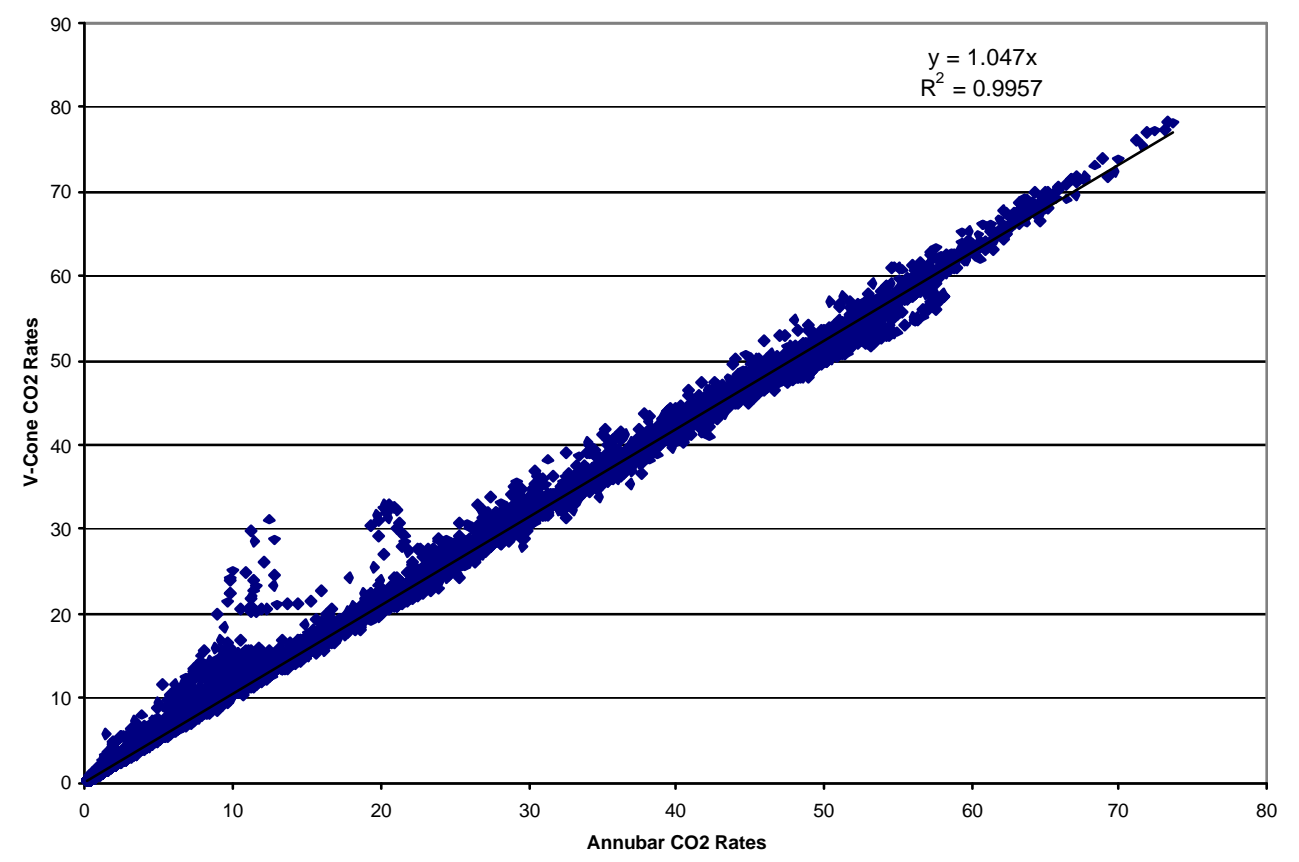

Figure 8.53 $\mathrm{CO}_{2}$ regression analysis for test VolvoPA1-01.

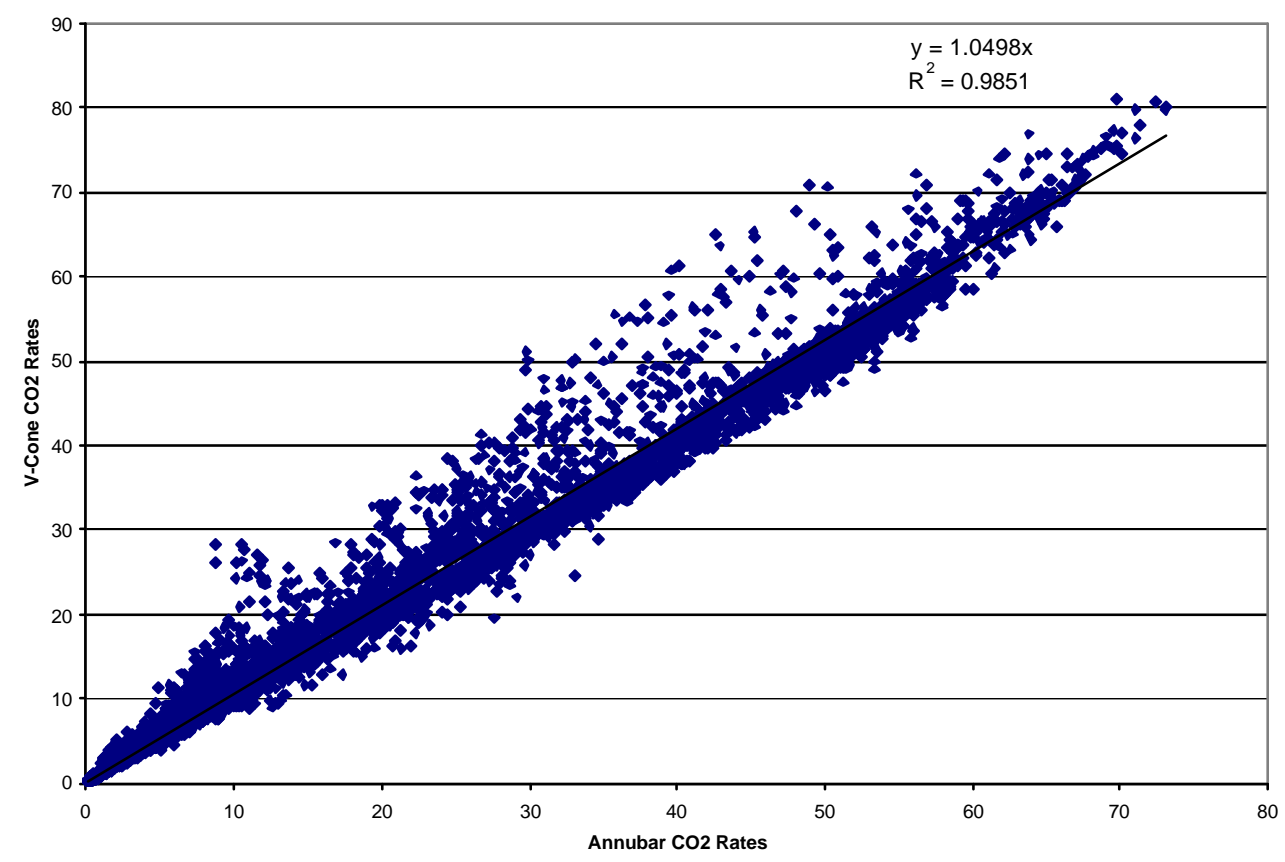

Figure 8.54 $\mathrm{CO}_{2}$ regression analysis for test VolvoPA1-02. 


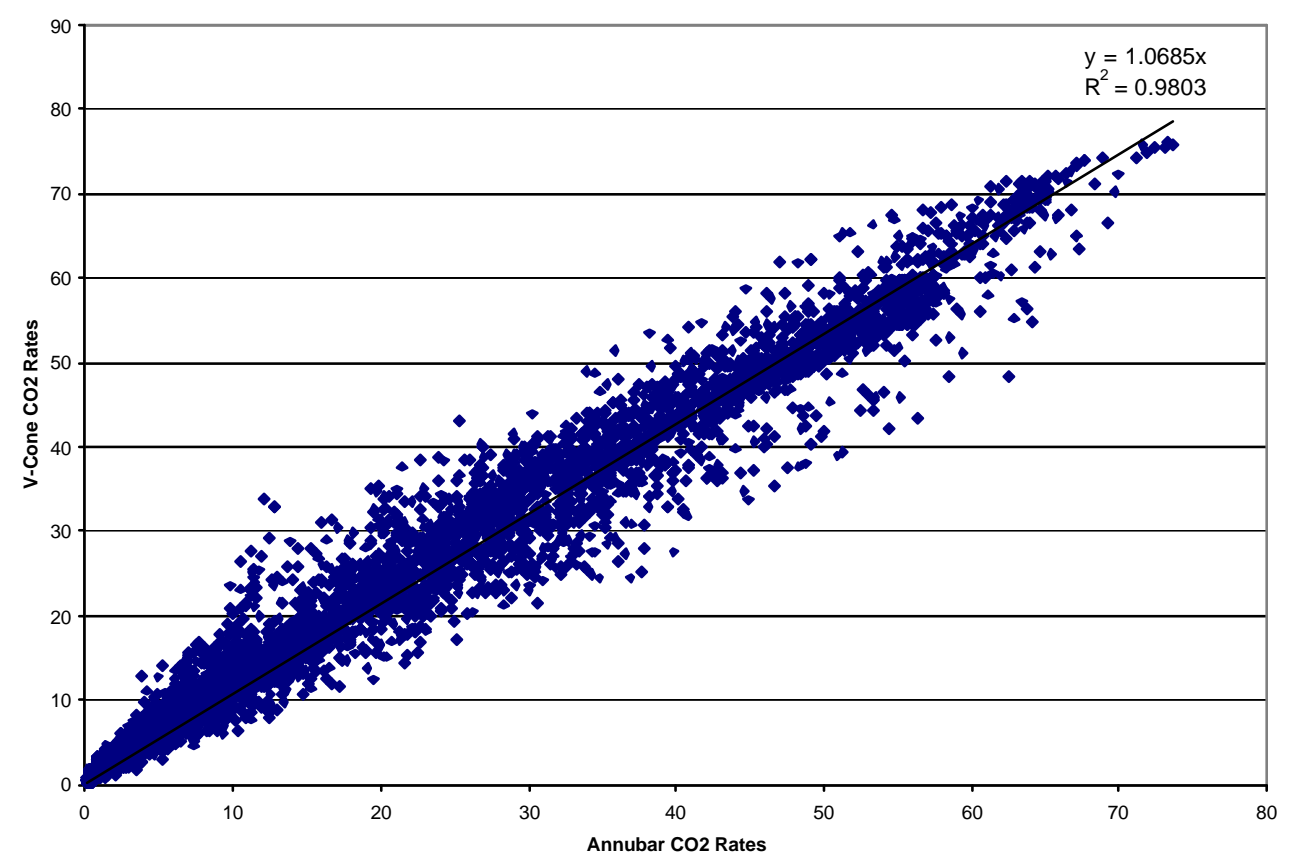

Figure 8.55 $\mathrm{CO}_{2}$ regression analysis for test VolvoPA1-03.

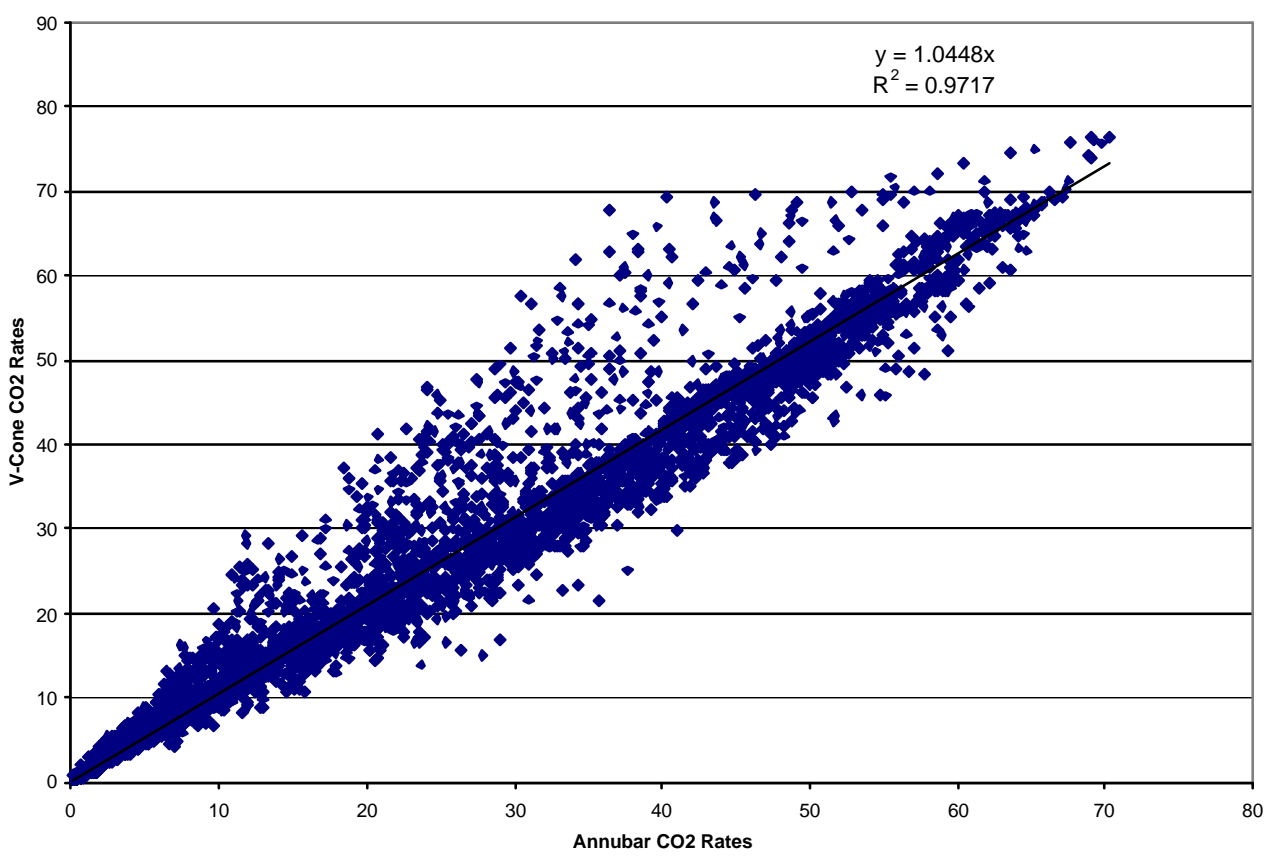

Figure 8.56 $\mathrm{CO}_{2}$ regression analysis for test VolvoPA1-04. 


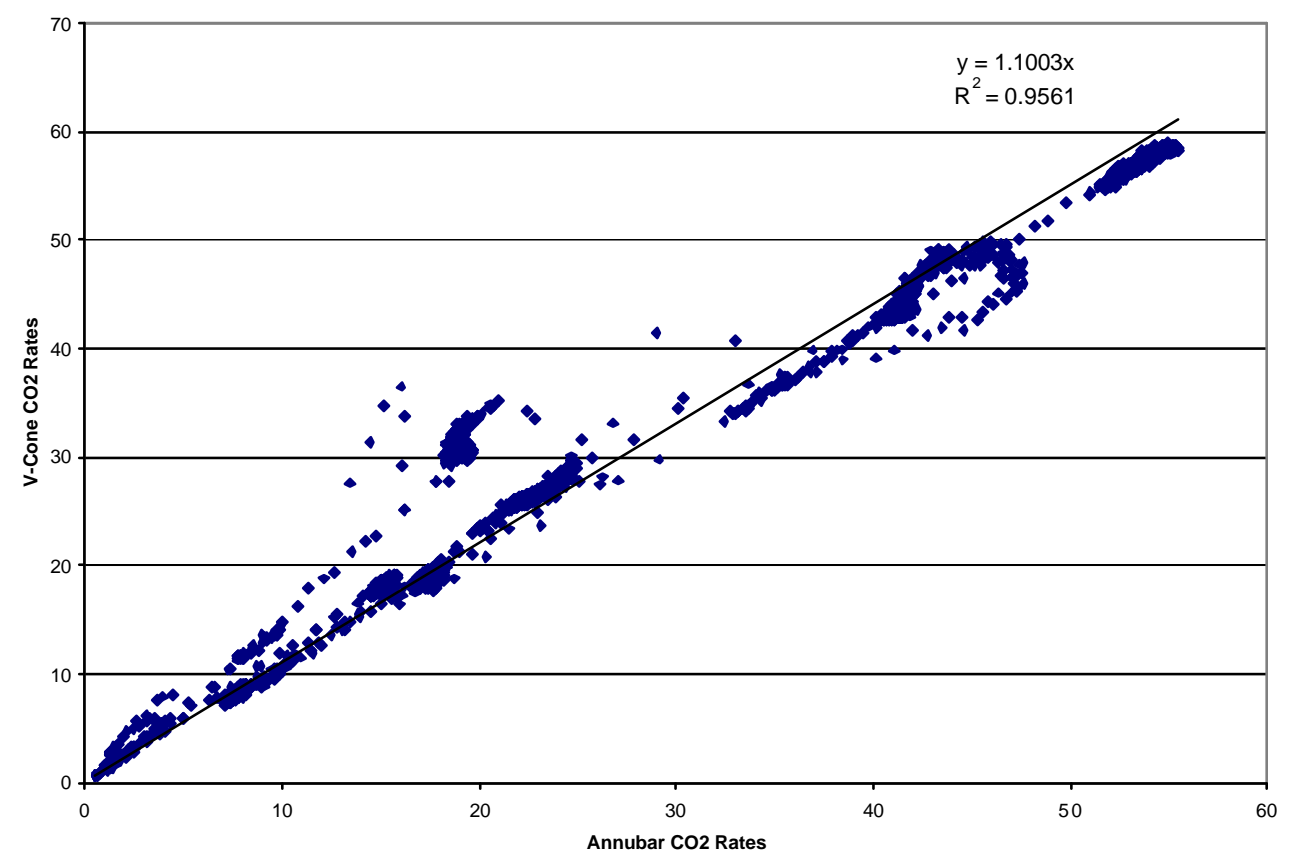

Figure 8.57 $\mathrm{CO}_{2}$ regression analysis for test VolvoSS2-01.

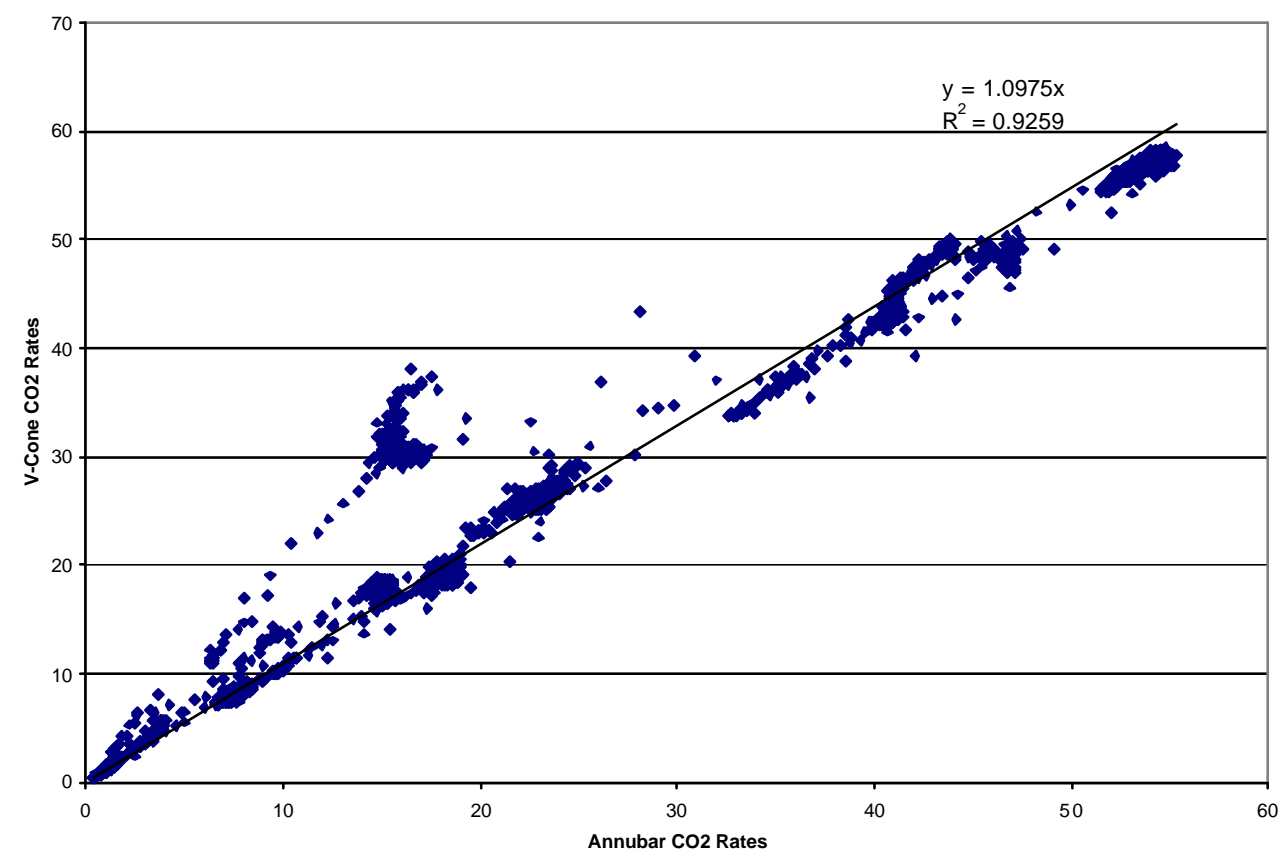

Figure 8.58 $\mathrm{CO}_{2}$ regression analysis for test VolvoSS2-02. 


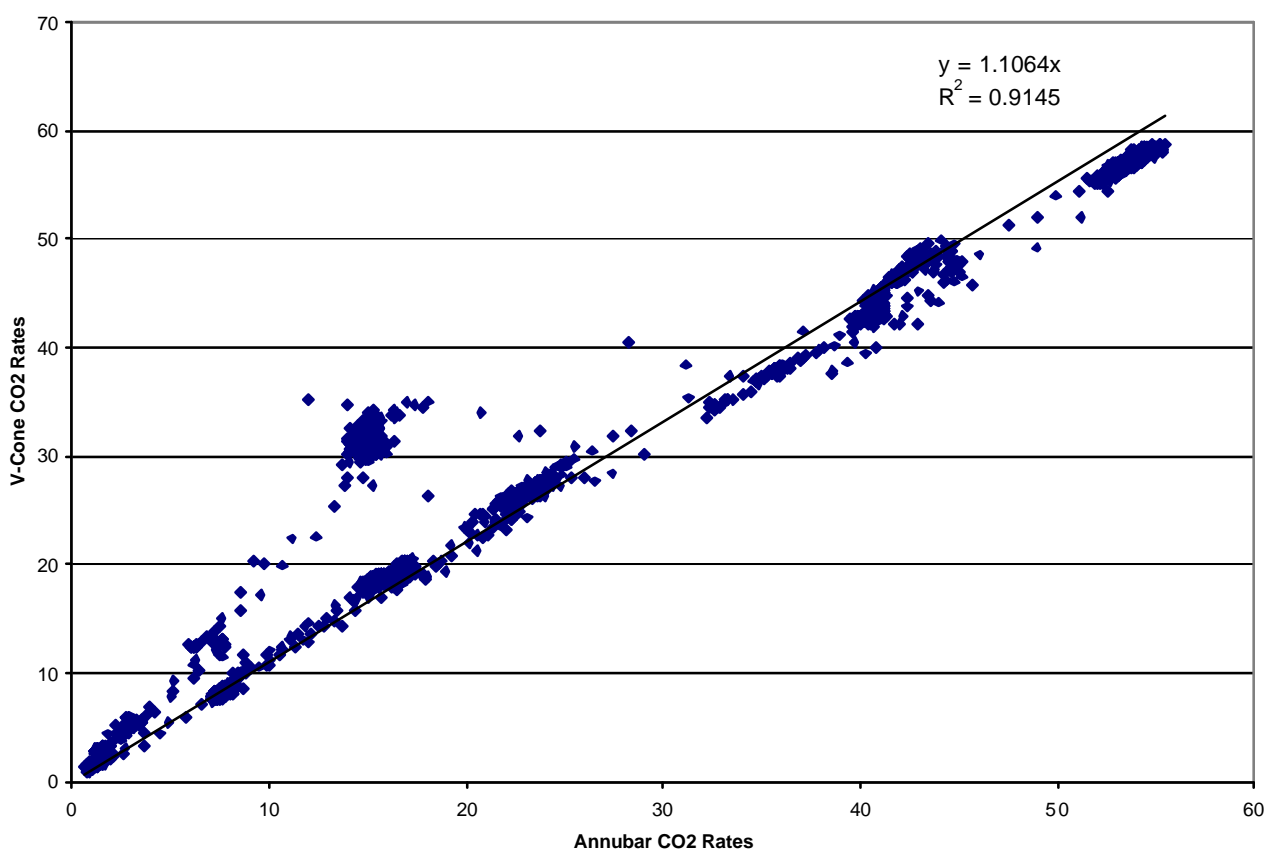

Figure 8.59 $\mathrm{CO}_{2}$ regression analysis for test VolvoSS2-03. 